\title{
Cardiovascular disease: role of immunosuppression and radiotherapy
}

Citation for published version (APA):

Gabriels, K. M. R. (2013). Cardiovascular disease: role of immunosuppression and radiotherapy. [Doctoral Thesis, Maastricht University]. Uitgeverij BOXPress. https://doi.org/10.26481/dis.20131220kg

Document status and date:

Published: 01/01/2013

DOI:

$10.26481 / \mathrm{dis} .20131220 \mathrm{~kg}$

Document Version:

Publisher's PDF, also known as Version of record

\section{Please check the document version of this publication:}

- A submitted manuscript is the version of the article upon submission and before peer-review. There can be important differences between the submitted version and the official published version of record.

People interested in the research are advised to contact the author for the final version of the publication, or visit the DOI to the publisher's website.

- The final author version and the galley proof are versions of the publication after peer review.

- The final published version features the final layout of the paper including the volume, issue and page numbers.

Link to publication

\footnotetext{
General rights rights.

- You may freely distribute the URL identifying the publication in the public portal. please follow below link for the End User Agreement:

www.umlib.nl/taverne-license

Take down policy

If you believe that this document breaches copyright please contact us at:

repository@maastrichtuniversity.nl

providing details and we will investigate your claim.
}

Copyright and moral rights for the publications made accessible in the public portal are retained by the authors and/or other copyright owners and it is a condition of accessing publications that users recognise and abide by the legal requirements associated with these

- Users may download and print one copy of any publication from the public portal for the purpose of private study or research.

- You may not further distribute the material or use it for any profit-making activity or commercial gain

If the publication is distributed under the terms of Article $25 \mathrm{fa}$ of the Dutch Copyright Act, indicated by the "Taverne" license above, 


\section{Cardiovascular disease: \\ Role of immunosuppression and radiotherapy}

Karen Gabriels 
Layout: Karen Gabriels

Cover design: Willem Vrancken

Printed by: Proefschriftmaken.nl || Uitgeverij BOXPress

Published by: Uitgeverij BOXPress, 's-Hertogenbosch

ISBN: 978-90-8891-754-7

(C) 2013 Karen Gabriels, Maastricht 


\title{
Cardiovascular disease: \\ Role of immunosuppression and radiotherapy
}

\author{
PROEFSCHRIFT \\ Ter verkrijging van de graad van doctor aan de Universiteit Maastricht, \\ op gezag van de Rector Magnificus, Prof. Dr. L.L.G. Soete, \\ volgens het besluit van het College van Decanen, \\ in het openbaar te verdedigen \\ op vrijdag 20 december 2013 om 10.00 uur
}

door

Karen Madeleine Roger Gabriels

geboren op 18 februari 1986 te Genk, België 


\section{Promotores}

Prof. dr. M.J.A.P. Daemen (AMC, Amsterdam)

Prof. dr. E.A.L. Biessen

\section{Copromotores}

Prof. dr. S. Heeneman

Dr. F. Stewart (NKI, Amsterdam)

\section{Beoordelingscommissie}

Prof. dr. P. Lambin (voorzitter)

Prof. dr. H.J.G.M. Crijns

Dr. M. van Eck (LUMC, Leiden)

Dr. W.T.V. Germeraad

Prof. dr. V.C.G. Tjan-Heijnen

The research described in chapters 4, 5 and 6 was supported by the Dutch Cancer Society (grant NKI 2008-3993) and the European Commission in the $7^{\text {th }}$ Framework Program for Nuclear Research and Training.

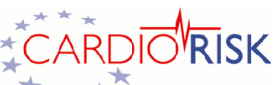

t $x+$ t

Financial support by the Dutch Heart Foundation and the Dutch Cancer Society for the publication of this thesis is gratefully acknowledged. 


\section{Contents}

$\begin{array}{lll}\text { Chapter } 1 & \text { General introduction } & 7\end{array}$

Chapter 2 Low- but not high-dose FK506 treatment confers atheroprotection due to alternative macrophage activation and unaffected cholesterol levels

Chapter 3 NFATC2 deficiency aggravates rather than protects against atherosclerosis by facilitating memory T-cell recruitment

Chapter $4 \quad$ Irradiation of existing atherosclerotic lesions increased inflammation by favoring pro-inflammatory macrophages

Chapter 5 Irradiation induced modest changes in murine cardiac function despite progressive structural damage to the myocardium and microvasculature

Chapter 6 Local heart irradiation of $\mathrm{ApoE}^{-/-}$mice induces microvascular and endocardial damage and accelerates coronary atherosclerosis

Chapter 7 General discussion

Summary

Samenvatting

List of abbreviations 

chapter one

4

ti

1

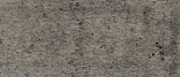

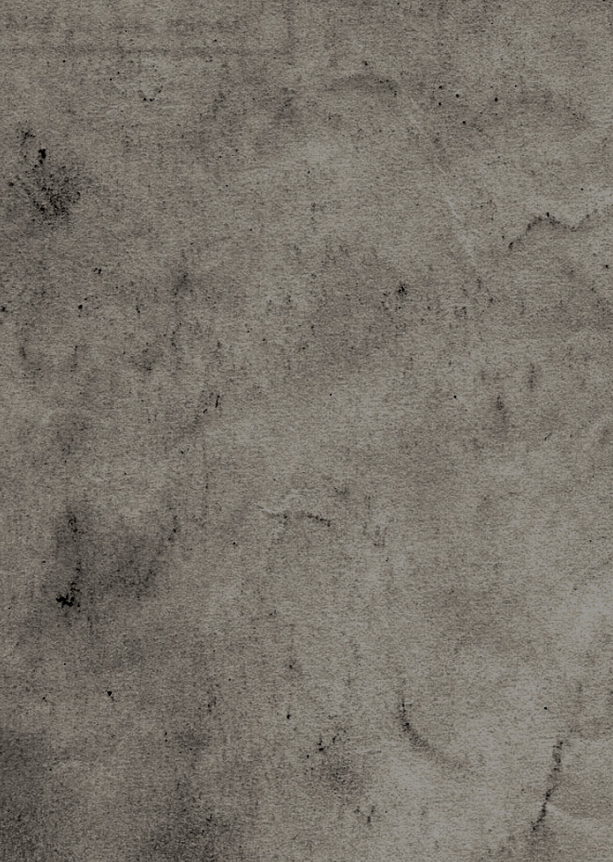

\section{General introduction}
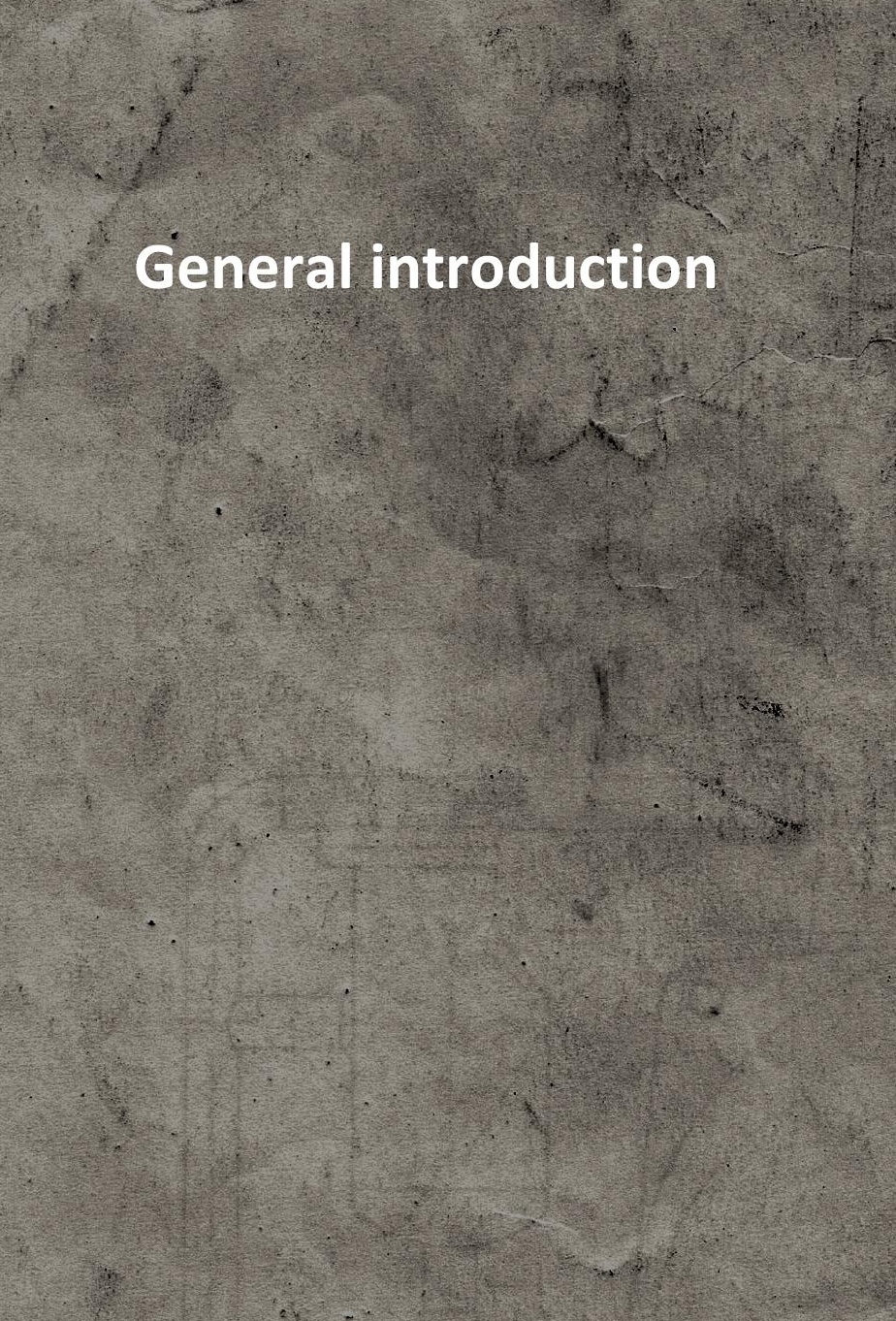

$\frac{1}{4}+\frac{1}{2}+4$ 
In 2012, almost one third of all deaths in the Netherlands was related to cardiovascular diseases (CVDs), such as coronary artery disease (CAD), peripheral artery disease and cerebrovascular disease (www.cbs.nl: health and welfare, key figures primary causes of death). Atherosclerosis, a chronic, lipiddriven disease of the arterial wall is the main cause of CVD. ${ }^{1-5}$ It is now widely acknowledged that atherosclerosis is an inflammatory disease, starting at early adolescence, at which both innate and adaptive immune responses play essential roles in its initiation and progression. How different immune cells contribute to the atherosclerotic process is extensively reviewed by Hansson et al. ${ }^{6}$ and Weber et al. ${ }^{7}$. In the first part of this introduction, we will focus on the vital role of diverse T-cell subtypes in atherosclerosis and evaluate T-cell immunosuppression as a potential therapeutic modality for atherosclerosis.

Radiation exposure has been identified as an independent risk factor promoting atherosclerosis, in addition to established factors such as genetic predisposition, hypertension, age, obesity, type 2 diabetes, smoking and stress. Radiotherapy of the thorax or head and neck region, including parts of the heart and major arteries, is commonly used in the primary treatment of several cancers with good long-term prognosis, such as breast cancer or Hodgkin's lymphoma. Unfortunately, survivors of these cancers are at risk to develop long-term treatment-related severe complications, including secondary cancers and normal tissue damage. ${ }^{8} \mathrm{CVDs}$, such as congestive heart failure, are among the most serious and life-threatening late adverse effects encountered by the growing number of cancer survivors who received therapeutic doses of thoracic radiotherapy. In the second part of this introduction, the most important epidemiological studies providing evidence of a strong correlation between radiation dose to the thorax or head and neck region and increased risk of developing CVD will be summarized. In addition, experimental data considering micro- and macrovascular damage, as well as direct cardiac damage, as major underlying pathologies of late morbidity and mortality after radiotherapy will be reviewed. Macrophages will be considered as key players in radiation-induced atherosclerosis. 


\section{Atherosclerotic plaque development}

Large arteries such as coronary, carotid and iliac arteries are susceptible to atherosclerotic plaque formation, especially at bifurcations due to hemodynamic factors like low shear stress and disturbed laminar flow. ${ }^{9-12}$ This leads to endothelial cell (EC) damage or dysfunction that results in increased permeability and, in the presence of hypercholesterolemia, subendothelial accumulation of lipoproteins. Activated ECs subsequently express chemokines (such as chemokine ( $\mathrm{C}-\mathrm{C}$ motif) ligands 2 (CCL2) and 5 (CCL5)) and adhesion molecules (such as E- and P-selectin and intercellular adhesion molecule-1 (ICAM-1)), which promote the initial contact between circulating leukocytes and the endothelium. EC-derived monocyte chemoattractant protein-1 (MCP-1 or CCL2) further promotes transmigration of monocytes into the intima via CCchemokine receptors type 2 (CCR2) and 5 (CCR5) and CX3CR1., ${ }^{5}$ In response to pro-inflammatory cytokines, such as macrophage-colony stimulating factor (M-CSF), interleukin (IL)-1, tumor necrosis factor $\alpha$ (TNF $\alpha$ ), interferon- $\gamma$ (IFN- - ) and growth factors, these monocytes differentiate into macrophages which ingest the accumulated modified lipids (mainly oxidized low-density lipoprotein (oxLDL)) via upregulated scavenger receptors (such as CD36, SR-A), and progress into foam cells. ${ }^{14-17}$ This will lead to intimal thickening and the formation of a fatty streak.

Once the atherosclerotic process is initiated, activated macrophages and lipid-loaded foam cells secrete inflammatory cytokines, reactive oxygen species (ROS), chemokines and growth factors. This will trigger further leukocyte recruitment and activation, as well as smooth muscle cell (SMC) proliferation and migration, leading to a stable, collagen-rich advanced lesion containing a necrotic core, modified lipids and a thick fibrous cap., ${ }^{3,}$ Extracellular matrix (ECM) degradation due to the action of matrix metalloproteinases (MMPs) and the ongoing cell death caused by sustained inflammation will eventually weaken the fibrous cap., ${ }^{78}$ Exposure of the prothrombotic content of the plaque to the blood during plaque rupture will result in occlusive thrombus formation, leading to acute fatal cardiovascular events such as a myocardial infarction or a stroke. ${ }^{19}$ The ruptured lesion may also heal, resulting in a stenotic vessel. ${ }^{20}$ 


\section{T-cell subtypes in atherosclerosis}

Naive T-cells in lymph nodes can differentiate into different types of effector Thelper (Th) cells such as $T h_{1}, T_{2}$ and $T h_{17}$ or regulatory T-cells (Tregs), each with their specific cytokine secretion profile. T-cell polarization depends on the antigen-presenting cell (APC) released cytokine profiles, on antigen presentation by major histocompatibility complexes (MHC) to the T-cell receptor (TCR), on the expression and cross-interaction of co-stimulatory molecules and on the nature and intensity of the antigenic stimulus itself. The effector T-cells are primed to migrate to inflamed sites, such as vascular lesions, where atherosclerosis-related antigens are presented to the T-cells by macrophages or dendritic cells, thus generating adaptive immune responses.

Different T-cell subsets have been characterized and $\mathrm{CD} 4^{+} \mathrm{T}$-cells are the dominant T-cells found in atherosclerotic lesions compared to $\mathrm{CD}^{+}$cytotoxic T-cells. $^{21} \mathrm{Th}_{1}$-cells are regarded as pro-inflammatory and induce cellular immunity by producing IFN- $\gamma$ and TNF $\alpha$, while $T_{2}$-cells secrete antiinflammatory IL-5, IL-13, IL-10 and IL-4 and mediate humoral immune responses by supporting antigen-specific antibody production by B-cells. ${ }^{22} \mathrm{Th}_{1}$ cells are the most abundant T-cell subtype in atherosclerosis and are regarded as being pro-atherosclerotic, partly because of the pro-inflammatory and collagen-degrading effects of IFN- $r .{ }^{6,23-25}$ Furthermore, patients with CAD have been shown to exhibit increased $\mathrm{Th}_{1}$-activation. ${ }^{26,}{ }^{27}$ Specific deficiencies in transcription factor T-bet ( $T$-box transcription factor TBX21), IFN- $\nu$ or its receptor in atherosclerosis-prone mouse models reduced lesion development and enhanced plaque stability by increased collagen deposition ${ }^{28,29}$, whereas exogenous administration of IFN- $\gamma$ itself or specific cytokines activating T-bet (IL-12, IL-18) accelerated disease progression. ${ }^{30-33}$ In addition, Elhage et al. demonstrated a marked reduction in plaque development and diminished $\mathrm{Th}_{1^{-}}$cell activity in atherosclerosis-prone apolipoprotein $\mathrm{E}(\mathrm{ApOE})^{-/-}$mice deficient in IL-18. ${ }^{34}$

On the contrary, the role of $\mathrm{Th}_{2}$-responses in atherosclerosis is not explicit and seems to depend on the location and stage of lesion development as well as on the experimental model. $\mathrm{Th}_{2}$-responses were originally thought to be atheroprotective by counteracting pro-atherogenic $\mathrm{Th}_{1}$-differentiation and responses. Nevertheless, dual and opposite effects of $\mathrm{Th}_{2}$-cytokines have been reported. IL-5 has a protective role through anti-oxLDL IgM antibody 
production $^{35}$ and IL-13 improves plaque stability by reducing plaque inflammation and inducing fibrosis ${ }^{36}$. IL-10 also exerts an atheroprotective function as its deficiency in $A p o E^{-/}$mice resulted in increased levels of atherosclerosis, thrombosis and rupture-prone plaques ${ }^{37}$. However, deficiency of IL-4 showed no substantial effect ${ }^{38}$ or even led to reduced site-specific plaque formation in hypercholesterolemic mice, indicating a pro-atherogenic effect. $^{39,40}$

Although $\mathrm{Th}_{17}$-cell accumulation recently has been observed in human ${ }^{41}$, 42 and murine ${ }^{43,44}$ atherosclerosis, the exact role of $\mathrm{Th}_{17}$-cells producing IL-17, IL-22 and IL-23 also remains controversial and poorly understood, as both pro-- ${ }^{41,43,45-50}$ and anti-atherogenic ${ }^{51,52}$ effects have been reported.

An additional subset, Treg, has been implicated in atherosclerosis as being atheroprotective by direct effects on T-cells or through effects on APCs. ${ }^{53-61}$ Natural Tregs develop in the thymus and are characterized by CD4, CD25 and forkhead box p3 (Foxp3) expression. These Tregs are important to maintain self-tolerance and prevent autoimmunity through the inhibition of lymphocytes, while so-called 'induced Tregs' in the periphery were seen to suppress the activation of effector T-cells and inhibit atherogenesis by secreting among others anti-inflammatory cytokines (transforming growth factor $\beta$ (TGF $\beta$ ) and IL-10). ${ }^{62-67}$ Adoptive transfer of Tregs attenuated atherosclerotic lesion development in $A p o E^{-/}$mice, pointing to a possible therapeutic use. ${ }^{61,68}$

\section{T-cell differentiation and NFAT}

The choice of T-cell differentiation into effector T-cell subsets is critically regulated by nuclear factor of activated T-cells (NFAT) (Figure 1). NFAT transcription factors are expressed in T-cells, B-cells, NK-cells and mast cells, as well as in cardiomyocytes, SMCs, ECs and macrophages. ${ }^{69}$ NFATC1, C2 and C3 family members play a key role in T-cell activation and are tightly regulated by calcium-calcineurin signaling. ${ }^{70}$ Upon engagement of the TCR and costimulatory receptors (such as CD28) that are coupled to the calcium-signaling pathway, calcineurin, a calmodulin-dependent calcium-activated phosphatase, docks on the regulatory domain of NFAT and subsequently dephosphorylates multiple phosphorylated serine residues. This will lead to the exposure of the nuclear localization signal and the translocation of NFAT to the nucleus of 
activated T-cells. There NFAT proteins cooperate with signal transducer and activator of transcription (STAT) proteins and other transcriptional partners (such as activator protein 1 (AP1)) activated by costimulatory signals to induce the expression of T-cell lineage-specific transcription factors T-bet $\left(\mathrm{Th}_{1}\right)$, GATAbinding protein 3 (GATA3) $\left(\mathrm{Th}_{2}\right)$, retinoid-related orphan receptor $\gamma^{\top}$ (Ror $\mathrm{T}$ ) $\left(\mathrm{Th}_{17}\right)$ and Foxp3 (Treg). In turn, these transcription factors and other partners, including NFAT, enhance the expression of a specific set of cytokines to maintain and commit to T-cell differentiation. Therefore, NFAT protein isoforms have selective roles in $\mathrm{Th}_{1} / \mathrm{Th}_{2} / \mathrm{Th}_{17}$-cell differentiation ${ }^{71}$, as well as in the development and immunosuppressive function of Tregs. ${ }^{72-74}$ The loss of NFATC2 (and NFATC3) diminishes Th $_{1}$-cell differentiation with reduced IFN- $\nu$ production, while expression of $\mathrm{Th}_{2}$-cytokines is markedly increased. ${ }^{75-79}$ Furthermore, mice expressing hyperactive NFATC2 exhibit enhanced IL-17 production. ${ }^{80}$ These results indicate that NFATC2 can promote $\mathrm{Th}_{1^{-}}$and $\mathrm{Th}_{17}{ }^{81}$ cell differentiation and negatively regulates $\mathrm{Th}_{2}$-immune responses. In contrast, NFATC1-deficient T-cells show impaired production of $\mathrm{Th}_{2}$-responses, suggesting that NFATC1 is required for $\mathrm{Th}_{2}$-cell differentiation. ${ }^{82,83}$ 


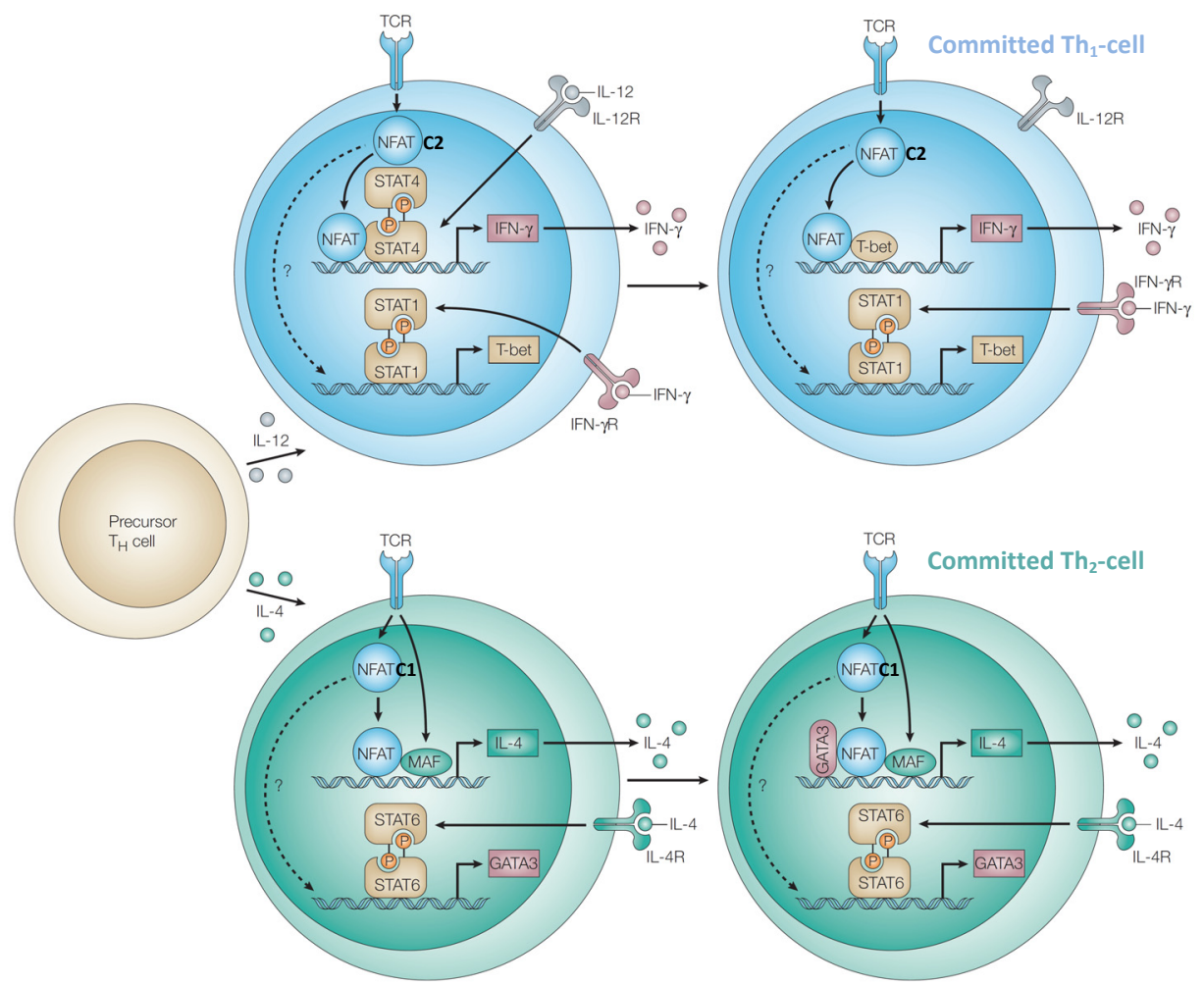

Figure 1. Role of NFAT transcription factors in $\mathrm{Th}_{1}$ - and $\mathrm{Th}_{2}$-cell differentiation. In response to IL12 receptor (IL-12R) engagement, NFAT proteins cooperate with STAT4 to induce the expression of IFN- $\gamma$. Signaling through the IFN- $\gamma$ receptor (IFN- $\gamma \mathrm{R}$ ) induces STAT1 activation and expression of the $\mathrm{Th}_{1}$-lineage specific transcription factor T-bet. Subsequently, NFAT proteins cooperate with T-bet to maintain and commit to $\mathrm{Th}_{1}$-cell differentiation through the induction of IFN- $\gamma$. The committed $\mathrm{Th}_{1}$-cells are then reactivated by the TCR pathway and the positive-feedback loop of the IFNY-STAT1 signaling pathway. In Th${ }_{2}$-cells, IL-4 signaling induced by c-MAF (cellular homolog of the V-MAF oncoprotein) and NFAT proteins causes the activation of STAT6, which promotes GATA3 expression. GATA3 together with NFAT and other costimulatory transcription factors drives IL-4 transcription and commits to $\mathrm{Th}_{2}$-cell differentiation. NFAT proteins might also cooperate with STAT factors to induce the expression of T-bet and GATA3. Data from mice lacking specific NFAT proteins indicate that NFATC2 is required for $\mathrm{Th}_{1}$-cell differentiation and negatively regulates $\mathrm{Th}_{2}$-cell differentiation, whereas NFATC1 promotes $\mathrm{Th}_{2}$-cell differentiation. Adapted from Macian. ${ }^{70}$ 


\section{Epidemiological studies on radiotherapy and risk of CVD}

Evidence of a long-term increased incidence of CVD after high therapeutic doses of thoracic irradiation can be extracted from many epidemiological studies on survivors of Hodgkin's lymphoma ${ }^{84-92}$, breast ${ }^{93-99}$ and head and neck cancer $^{100,101}$.

In comparison to the general population and patients not receiving radiotherapy, survivors of Hodgkin's lymphoma show strongly elevated risk (2 to $>7$-fold greater) of cardiac death (mainly due to congestive heart failure and valve disease), depending on the method of radiotherapy (older techniques include whole heart and aortic arch in the irradiation field), use of anthracycline chemotherapy (enhanced risk) and follow-up time (increased risk with time). For instance, significantly increased standardized incidence ratios of various heart diseases (myocardial infarction 2.4 (95\% confidence interval (Cl) 1.1-5.2), angina 4.9 (2.0-12.0), valve disease 7.0 (2.6-18.5), congestive heart failure 7.4 (1.8-30.0)) were observed in patients treated for Hodgkin's lymphoma before the age of 41 years, who normally would be at low risk, even after a follow-up of more than 20 years. ${ }^{102}$

Furthermore, excess morbidity and mortality from heart disease is also a well-described late effect of post-operative radiotherapy observed from several randomized trials of women with breast cancer. The benefit of radiotherapy in reducing cancer-related deaths was offset by an increased relative risk (RR) of cardiac death. ${ }^{103,}{ }^{104}$ The RR was proportional to the estimated mean cardiac dose, increasing with $3.1-7.4 \%$ per Gray (Gy). ${ }^{105,} 106$ Moreover, the RR of cardiac mortality in irradiated breast cancer patients was higher for left-side- (mean cardiac dose of $12 \mathrm{~Gy}, \mathrm{RR} 1.44$ ) vs. right-side-treated patients (mean cardiac dose of $5 \mathrm{~Gy}, \mathrm{RR}$ 1.18) and increased with time from irradiation. Data from a recent study, including 35,000 women treated with radiotherapy for breast cancer and a follow-up of 30 years, provided further evidence of increased incidence ratios of heart diseases (acute myocardial infarction 1.22 (95\% Cl 1.06-1.42), pericarditis 1.61 (1.06-2.43), angina 1.25 (1.05-1.49) and valvular heart disease 1.54 (1.11-2.13)) in women irradiated for left-sided breast cancer (estimated mean total heart dose of $6.3 \mathrm{~Gy}$ compared to $2.7 \mathrm{~Gy}$ for right-sided tumors). ${ }^{107}$ 
In addition, radiotherapy treatment (total fractionated doses of 60-70 Gy) of head and neck cancer patients, during which the carotid arteries are fully located in the irradiation field, has also been shown to be an independent risk factor for death from stroke at more than 10 years after the treatment. ${ }^{101}$

Data from studies on human tissue revealing the possible underlying pathogenesis of radiation-induced CVDs are scarce. ${ }^{108}$ An induction or acceleration of atherosclerosis in major arteries located in the irradiation field is considered to play a fundamental role. Indeed, intima-media thickening (IMT), an early sign of atherosclerosis ${ }^{109,}{ }^{110}$, and an increased luminal narrowing have already been observed within a few years after receiving high radiation doses, resulting in carotid artery stenosis and consequently ischemic cerebrovascular diseases. ${ }^{111-113}$ Muzaffar and colleagues estimated that the rate of progression of IMT was 21 times that expected in the general population. $^{114}$

\section{Experimental studies on radiation-induced vascular damage and atherosclerosis}

Radiation is a potent inducer of inflammatory and thrombotic changes in ECs. Experimental studies have shown that irradiation ( $\geq 2 \mathrm{~Gy}$ ) of the endothelium induced endothelial dysfunction associated with increased expression of various inflammatory cytokines (IL-6 and IL-8) $)^{115}$ and adhesion molecules (Eand P-selectin ${ }^{116-118}$, ICAM $^{116,117,119-125}$ ), as well as loss of thromboresistance (increased expression of von Willebrand Factor (VWF) and thromboxane (TXA2), and decreased production of prostacyclin, thrombomodulin (TM) and ADPase $)^{126-130}$. In the microcirculation, radiation can cause EC detachment or apoptosis $^{131}{ }^{132}$, leading to exposure of the pro-thrombotic subendothelial matrix and SMCs with subsequent microthrombi formation and tissue ischemia.

Recent studies using hypercholesterolemic animals receiving local irradiation to large arteries, mimicking the clinical situation for certain cancer patients, demonstrated that the process of radiation-induced atherosclerosis development was different from age-related atherosclerosis. Single as well as fractionated doses of radiation not only initiated and accelerated the process of atherosclerosis, but also predisposed to the formation of highly inflammatory, macrophage-rich, thrombotic plaques, more likely to rupture 
and to cause a fatal myocardial infarction or stroke. ${ }^{133-136}$ This was shown by studies of Stewart et al. in which young atherosclerosis-prone $\mathrm{ApoE}^{--}$mice received radiation (single dose of $14 \mathrm{~Gy}^{134}$ or fractionated doses of $20 * 2 \mathrm{~Gy}^{133}$ ) to the neck region (Figure 2), including both carotid arteries, and were followed-up for up to 34 weeks. In contrast, irradiation of C57BL/6J wild-type mice on a normal chow did not result in signs of (early) atherosclerosis, suggesting that radiation-induced inflammatory responses are acting in concert with the effects of hypercholesterolemia to determine disease severity.
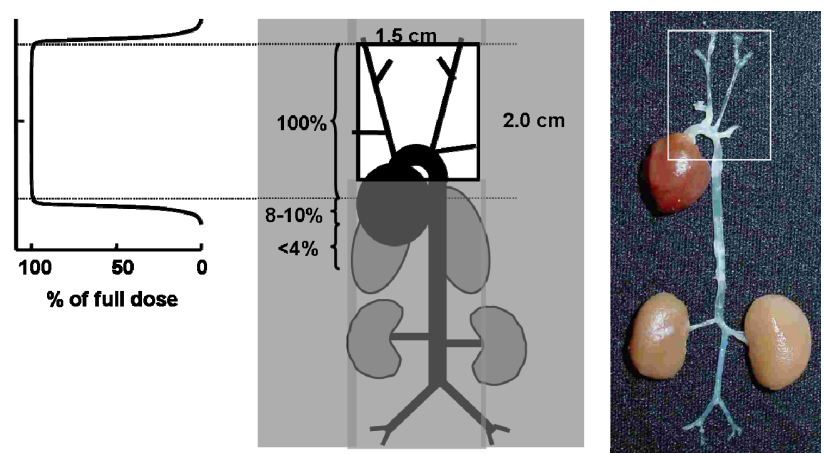

Figure 2. Irradiation field and dose distribution to the arterial tree. Reproduced with permission of Stewart et al. ${ }^{134}$

These experimental data indicate that the increased long-term risk for cardiovascular events after local high therapeutic doses is in part determined by radiation-induced atherosclerosis. Moreover, total body irradiation has to be considered in the risk for CVD. While no systemic changes in inflammatory markers or increased cholesterol levels have been reported after local irradiation of the neck region ${ }^{134}$, total body exposure increases circulating inflammatory markers (C-reactive protein (CRP), IL-6, TNF $\alpha)^{137}$, cholesterol $^{138,}$ 139 and blood pressure ${ }^{140}$. Furthermore, whole-body radiation dose was recently associated with renal failure. ${ }^{141}$ These systemic effects can impact atherosclerosis and cardiac mortality. ${ }^{142}$ Follow-up studies of atomic-bomb survivors provide strong evidence of increased risk for heart diseases after total body exposures of $<2.5 \mathrm{~Gy}$. ${ }^{143}$ 


\section{Macrophages and tissue damage}

Cells of the innate immune system, such as monocytes/macrophages and dendritic cells, play a central role in inflammation and tissue damage, and mediate the direct response to pathogens by recognizing pathogen-associated molecular patterns (PAMPs) via Toll-like receptors (TLRs). ${ }^{144}$

Monocytes/macrophages are the most prominent cells of the innate immune system. It is known that the target for the biological effects of radiation is larger than the directly irradiated cells. ${ }^{145}$ Cells exposed to ionizing radiation induce genomic instability in unirradiated descendants or release signals that can induce damage in neighboring non-targeted cells, known as bystander effects. ROS ${ }^{146,147}$, IL-8 $8^{148}$, TGF $^{149-151}$ and TNF ${ }^{152}$ are among others proposed as bystander messengers. Radiation-induced cytotoxic effects include reduced clonogenic survival ${ }^{153}$, genomic instability ${ }^{154-156}$ manifested by increased sister chromatid exchange ${ }^{157}$, chromosomal aberrations ${ }^{158}$, formation of micronuclei and apoptosis ${ }^{159-161}$, and altered gene expression and level of RNA transcripts ${ }^{162-164}$. Clastogenic factors that can cause damage to chromosomes in unirradiated cells have been shown in the blood of radiotherapy patients, Chernobyl liquidators and atomic bomb survivors. ${ }^{165-168}$ Lorimore et al. recently showed that bone-marrow derived macrophages (BMDM) from irradiated $\mathrm{CBA} / \mathrm{Ca}$ mice, susceptible to radiation-induced acute myeloid leukemia, were able to cause chromosomal instability in the clonal descendants of non-irradiated stem cells as a consequence of proinflammatory cytokine signaling. ${ }^{169}$ Thus, macrophages can contribute to nontargeted and delayed radiation effects. In atherosclerotic plaques, both direct and indirect macrophage responses following radiation exposure should be considered in radiation-induced vascular damage.

In age-related atherosclerosis (i.e. non-radiation-induced), macrophages clear the accumulated lipids and play an essential role in the development and progression of lesions. ${ }^{7}$ In the absence of macrophages, hypercholesterolemia was not sufficient to drive the process of atherosclerosis. ${ }^{170,}{ }^{171}$ Blood monocytes continuously adhere to and transmigrate through the EC layer to differentiate into tissue macrophages, contributing to chronic inflammation in atherosclerosis. ${ }^{172}$ 
Once differentiated, macrophages retain the ability to efficiently respond to specific micro-environmental stimuli and subsequently polarize into two main phenotypic states, classically-activated M1 macrophages and alternatively-activated M2 macrophages. ${ }^{173-181}$ M1 macrophages are classified as being pro-inflammatory. Their activation is dependent on pro-inflammatory $\mathrm{Th}_{1}$-cytokines, such as IFN- $\gamma$ and TNF $\alpha$, and TLR activation by exogenous stimuli such as microbial lipopolysaccharides (LPS) or endogenous stimuli such as oxLDL. M1 macrophages are responsible for promoting inflammation by producing high levels of pro-inflammatory cytokines, including IL-1 $\beta$, IL-6, IL12, IL-23 and TNF $\alpha$, supporting $\mathrm{Th}_{1}$ - and $\mathrm{Th}_{17}$-differentiation and expansion, as well as reactive nitrogen and oxygen species. Inducible nitric oxide synthase (iNOS) is an enzyme that allows M1 macrophages to metabolize arginine into nitric oxide (NO) for microbial killing.

Conversely, M2 macrophages are responsible for the resolution of inflammation and support Treg and $\mathrm{Th}_{2}$-associated effector functions. $\mathrm{M} 2$ macrophages are further subdivided based on their stimuli and secretome; M2a macrophages are referred to as 'wound-healing macrophages' mediating tissue repair, while M2b and M2c are known as 'regulatory macrophages'. IL-4 and IL-13, most likely produced by mast cells, granulocytes and $\mathrm{Th}_{2}$-cells within the atherosclerotic plaque, stimulate arginase 1 (Arg1) activity in M2a macrophages, allowing them to convert arginine to ornithine, a precursor of polyamines and collagen. Thereby M2a macrophages contribute to the production of ECM, indicating homeostatic repair and remodeling functions of macrophages beyond defense. Secretion of fibronectin and insulin-like growth factor, enhancing ECM deposition, is also supported by IL-4 and IL-13 stimulation. $\mathrm{M} 2 \mathrm{~b}$ and $\mathrm{M} 2 \mathrm{c}$ macrophages predominantly secrete antiinflammatory mediators, notably $\mathrm{IL}-10$ that restricts the production of proinflammatory mediators by surrounding cells, including M1 macrophages. These potent immunosuppressors are generated by immune complexes (M2b) or prostaglandins, adenine nucleotides, glucocorticoids, apoptotic cells and even IL-10 itself (M2c).

Commonly used markers to identify M1 and M2 macrophages are listed in Table 1. Although general properties of macrophages are conserved between mice and human, there are no human homologs of particular markers (e.g. Ym1, FIZZ1 and Arg1). ${ }^{182-185}$ Therefore, it remains crucial to expand our 
understanding of the interspecies differences in macrophage marker expression to take the next step in translational atherosclerosis research.

Table 1. Selection of M1 and M2 macrophage-specific markers.

\begin{tabular}{lll}
\hline & M1-macrophages & M2-macrophages \\
Transcription factors & NFKB p65, STAT1, IRF1 & NFKB p50, PPAR- $\gamma$, LXR $\alpha$, STAT6 (M2a) \\
& & STAT3 (M2b/c) \\
Intracellular enzymes & iNOS, Arg2 & Arg1, TGM2 \\
Secrete & IL-6, IL-8, IL-12, IL-13, IL-23, TNF $\alpha$, MCP-1 & IL-10, DCIR, Ym1, FIZZ1, IGF1, TGF 3 \\
& CXCL9, 10, 11 & CCL17, 24 \\
Cell surface & MARCO & MR \\
\hline
\end{tabular}

$\mathrm{NFKB}=$ nuclear factor $\mathrm{KB}, \mathrm{STAT}=$ signal transducers and activators of transcription, IRF1= interferon regulatory factor 1 , PPAR- $\gamma=$ peroxisome proliferator-activated receptor- $\nu, \operatorname{LXR} \alpha=$ liver $X$ receptor $\alpha$, iNOS= inducible nitric oxide synthase, $\mathrm{Arg}=$ arginase, $\mathrm{TGM} 2=$ transglutaminase $2, \mathrm{IL}=$ interleukin, $\mathrm{TNF} \alpha=$ tumor necrosis factor $\alpha, M C P-1=$ monocyte chemotatic protein-1, DCIR= dendritic cell immuno receptor, $\mathrm{Ym} 1=$ chitinase-like lectin, FIZZ1= found in inflammatory zone 1, IGF1= insulin-like growth factor $1, T G F \beta=$ transforming growth factor $\beta, \quad C X C L=C X$ chemokine ligands, $C C L=C C$ chemokine ligands, $M A R C O=$ macrophage receptor with collagenous structure, $M R=$ mannose receptor (CD206).

Macrophages are the major cellular components of an atherosclerotic lesion and the $\mathrm{M} 1 / \mathrm{M} 2$ balance can impact plaque progression and stability by determining cholesterol homeostasis and the level of efferocytosis (i.e. clearing of apoptotic cells by phagocytosis) and necrosis, as well as by producing pro- and anti-inflammatory mediators, chemokines and tissuedegrading MMPs. ${ }^{186}$ Macrophages expressing markers of M1 or M2 activation have been demonstrated in human and experimental atherosclerotic lesions ${ }^{187}$ 189 and recently additional macrophage subsets have been identified (Mox/Mha ${ }^{190-192}$ and M4 macrophages ${ }^{193,194}$ ).

As described above, radiation predisposed to the formation of macrophage-rich plaques in hypercholesterolemic animals ${ }^{133-136}$, but the effect of high therapeutic doses on macrophage polarization has not been characterized. Of note, Monceau et al. recently found increased M1 macrophages and IL- 6 in the heart of $A p o E^{-/}$mice after local low- (0.2 Gy) and intermediate- (2 Gy) radiation doses. ${ }^{195}$ 


\section{Experimental studies on radiation-induced cardiac damage}

Radiotherapy of the thorax, including part of the heart, is commonly used in the primary treatment of several cancers with good long-term prognosis. Cardiomyocytes are well-differentiated cells and relatively radio-resistant. ${ }^{89,} 196$ Indirect myocyte damage caused by both radiation-induced inflammation and macrovascular injury leading to accelerated coronary atherosclerosis, and microvascular EC damage resulting in a reduction of myocardial capillary density, are therefore believed to be the major underlying causes of myocardial degeneration and heart failure occurring decades after irradiation. ${ }^{196-198}$ Experimental studies using rabbits and rats receiving a single cardiac dose of 15 to $20 \mathrm{~Gy}$ indicated that radiation damage to the microvasculature of the heart was the earliest morphological change observed after irradiation. ${ }^{197-201}$ This is supported by clinical studies showing myocardial perfusion changes at 6 months after irradiation using functional imaging in asymptomatic breast cancer patients. ${ }^{202,} 203$ Furthermore, left-sided breast cancer patients receiving radiotherapy suffered perfusion defects within the part of the left ventricle exposed to high-dose irradiation that persisted for years after the treatment. ${ }^{204,205}$ Radiation-induced capillary endothelial dysfunction, indicated by a focal loss of the endothelial marker enzyme alkaline phosphatase (ALP) and increased deposition of VWF, results in thrombus formation, obstruction of the microvessels and a progressive reduction in the number of capillaries. This will eventually lead to focal ischemia, myocardial cell death and replacement of cardiac tissue by interstitial fibrosis. ${ }^{126,198,201,206-209}$

Studies by Schultz-Hector et al. showed that rats receiving local heart irradiation of $\geq 15$ Gy suffered premature death. Histological analysis of heart tissue revealed extensive focal myocardial damage. Clinical manifestations reported months to several years after high-dose heart irradiation include acute pericarditis (i.e. inflammation of the pericardium associated with protein-rich exudate), cardiomyopathy, pericardial and myocardial fibrosis, valvular disorders, conduction abnormalities, CAD and sudden death. ${ }^{89}, 105,196$, 201, 210-218 Diffuse myocardial fibrosis can lead to cardiac rhythm disturbances by impairing myocardial relaxation. ${ }^{215}$ Adverse cardiac remodeling in irradiated rat hearts correlated with mast cell hyperplasia, suggesting that mast cells mediate collagen deposition after radiotherapy. ${ }^{219}$ In addition, radiation can 
induce senescent changes in fibroblasts ${ }^{220,221}$, leading to excessive collagen production $^{222}$ mediated by increased TGF $\beta$ levels and downstream Smad protein signaling ${ }^{195,223-225}$. Hilbers et al. reported an association between TGF $\beta 1$ single nucleotide polymorphism and CVD risk in long-term breast cancer survivors. ${ }^{226}$

Radiation-induced valvular abnormalities present late after therapeutic radiation as thickening, fibrosis and calcification of the cusp and/or leaflets of valves, leading to functional impairment. ${ }^{88,210}$ 


\section{Thesis hypothesis}

Calcineurin-NFAT signaling, responsible for the transcriptional activation of cytokine genes, has emerged as an attractive target in the regulation of immune responses. Inhibitors of calcineurin, such as cyclosporin A (CsA) and FK506 (tacrolimus) ${ }^{227}$, have been extensively used as immunosuppressive agents after organ transplantation. Nevertheless, calcineurin can regulate various downstream targets besides NFAT, and high dose and long-term use of these drugs in transplant recipients increased the risk for severe complications such as infections ${ }^{228}$ and CVDs $^{229}$ (due to hyperlipidemia and hypertension). Experimental studies investigating the effect of anti-inflammatory CsA and FK506 treatment on atherosclerosis showed conflicting results, with either increased $^{230-232}$ or decreased plaque development ${ }^{233,234}$. However, different doses were given. We therefore hypothesize that the dosage of immunosuppressive drugs is critical in NFAT-regulated inflammatory responses and atherosclerosis.

A major drawback of the clinical use of calcineurin inhibitors, such as FK506 or CsA, is that these drugs also affect numerous other downstream effectors of calcineurin besides NFAT (like protein kinase $C$ activation or NFKB activity), thereby creating adverse side-effects and toxicity such as nephro- and neurotoxicity, hypertension and hyperlipidemia. ${ }^{229,}{ }^{235-246}$ We propose that specifically blocking the NFATC2 pathway (mediating $\mathrm{Th}_{1}$ pro-atherogenic immune responses and regulating Treg development and immunosuppressive function) will circumvent the regulation of undesired targets while still protecting against atherosclerotic plaque development and progression.

The influence of irradiation on pre-existing lesions is unknown. As previous studies from our group demonstrated that radiation exposure to major arteries accelerated the development of atherosclerotic plaques in $A p o E^{\prime-}$ mice and predisposed to an inflammatory, pro-thrombotic plaque phenotype ${ }^{133,134}$, we suggest that radiation of pre-existing lesions will accelerate the atherosclerotic process by skewing towards a more inflammatory plaque phenotype.

Recent epidemiological and experimental evidence shows that thoracic radiotherapy increases the long-term risk for cardiovascular morbidity and mortality. Although microvascular damage and the development of coronary lesions are suggested to play crucial roles, the pathogenesis of radiation- 
induced cardiotoxicity has not been studied in detail. We hypothesize that cardiac irradiation will lead to increased myocardial damage with time and dose by stimulating coronary atherosclerosis and/or by causing progressive damage to the capillary network.

\section{Thesis outline}

There is a clear discrepancy between the possible protective effect of immunosuppressive drugs against atherosclerosis and adverse side effects after long-term use. However, variation in dosage of the drug might explain this discrepancy. In a previous experimental study from our laboratory, lowdose FK506 was able to inhibit the progression of atherosclerosis, without affecting systemic immunological parameters. We therefore expect low-dose FK506 treatment to be the most suitable for long-term therapy. In chapter 2, we further explored low- and high-dose FK506 treatment on collar-induced carotid atherosclerosis and relevant inflammatory mediators to fully comprehend dose-dependent mechanisms of FK506 and associated sideeffects.

NFATC2, activated by calcium-calcineurin signaling, is a crucial transcriptional regulator of inflammatory genes during immune responses, such as pro-inflammatory IL-2, IFN- $\gamma$ and TNF $\alpha$. Therefore it is an attractive target for treatment of $\mathrm{Th}_{1}$-driven atherosclerosis and prevention of unwanted side-effects associated with calcineurin inhibitors. In chapter 3, we studied the effect of NFATC2 hematopoietic and whole-body depletion in low-density lipoprotein receptor $(L D L r)^{-/}$mice.

As the majority of cancer patients involve the elderly, radiotherapy will generally be applied in patients suffering from moderate to advanced atherosclerosis. From a clinical point of view, it is therefore crucial to focus on the effect of radiotherapy on pre-existing atherosclerotic lesions. For that reason, we irradiated atherosclerotic $A p o E^{-/}$mice to the neck region to mimic the clinical situation for aged cancer patients (chapter 4). To elucidate the mechanisms responsible for inflammatory responses and potential ongoing damage in atherosclerotic plaques long-term after the initial radiation insult, in vitro studies were performed, focusing on the effect of irradiation on macrophage polarization and function. 
We further explored the contribution of macro- and microvascular damage in the pathogenesis of radiation-induced heart disease. The main objective was to evaluate the dose and time dependence of structural and functional cardiovascular damage after heart irradiation in wild-type C57BL/6J (chapter 5) and hypercholesterolemic $A p o E^{-/}$mice (chapter 6). We showed that radiation-induced pro-inflammatory responses and loss or damage of ECS are most likely the driving forces for cardiac microvascular defects and enhanced atherosclerosis development in coronary arteries.

Finally, in chapter $\mathbf{7}$ major findings of this thesis and future implications are discussed. 


\section{References}

1. Hansson GK. Inflammation, atherosclerosis, and coronary artery disease. The New England journal of medicine. 2005;352:1685-1695

2. Libby P, Ridker PM, Maseri A. Inflammation and atherosclerosis. Circulation. 2002;105:1135-1143

3. Lusis AJ. Atherosclerosis. Nature. 2000;407:233-241

4. Stary HC. Evolution and progression of atherosclerotic lesions in coronary arteries of children and young adults. Arteriosclerosis. 1989;9:119-32

5. Ross R, Glomset J, Harker L. Response to injury and atherogenesis. The American journal of pathology. 1977;86:675-684

6. Hansson GK, Hermansson A. The immune system in atherosclerosis. Nature immunology. 2011;12:204-212

7. Weber C, Zernecke A, Libby P. The multifaceted contributions of leukocyte subsets to atherosclerosis: Lessons from mouse models. Nature reviews. Immunology. 2008;8:802-815

8. Adams MJ, Hardenbergh PH, Constine LS, Lipshultz SE. Radiation-associated cardiovascular disease. Critical reviews in oncology/hematology. 2003;45:55-75

9. Caro CG. Discovery of the role of wall shear in atherosclerosis. Arteriosclerosis, thrombosis, and vascular biology. 2009;29:158-161

10. Cheng C, Tempel D, van Haperen R, van der Baan A, Grosveld F, Daemen MJ, Krams R, de Crom R. Atherosclerotic lesion size and vulnerability are determined by patterns of fluid shear stress. Circulation. 2006;113:2744-2753

11. VanderLaan PA, Reardon CA, Getz GS. Site specificity of atherosclerosis: Site-selective responses to atherosclerotic modulators. Arteriosclerosis, thrombosis, and vascular biology. 2004;24:12-22

12. Zarins CK, Giddens DP, Bharadvaj BK, Sottiurai VS, Mabon RF, Glagov S. Carotid bifurcation atherosclerosis. Quantitative correlation of plaque localization with flow velocity profiles and wall shear stress. Circulation research. 1983;53:502-514

13. Weber $\mathrm{C}$, Noels $\mathrm{H}$. Atherosclerosis: Current pathogenesis and therapeutic options. Nature medicine. 2011;17:1410-1422

14. Greaves DR, Gordon S. The macrophage scavenger receptor at 30 years of age: Current knowledge and future challenges. Journal of lipid research. 2009;50 Suppl:S282-286

15. Libby P, Geng YJ, Aikawa M, Schoenbeck U, Mach F, Clinton SK, Sukhova GK, Lee RT. Macrophages and atherosclerotic plaque stability. Current opinion in lipidology. 1996;7:330-335

16. Nicholson AC, Frieda S, Pearce A, Silverstein RL. Oxidized Idl binds to cd36 on human monocyte-derived macrophages and transfected cell lines. Evidence implicating the lipid moiety of the lipoprotein as the binding site. Arteriosclerosis, thrombosis, and vascular biology. 1995;15:269-275

17. Endemann G, Stanton LW, Madden KS, Bryant CM, White RT, Protter AA. Cd36 is a receptor for oxidized low density lipoprotein. The Journal of biological chemistry. 1993;268:11811-11816

18. Newby AC. Dual role of matrix metalloproteinases (matrixins) in intimal thickening and atherosclerotic plaque rupture. Physiological reviews. 2005;85:1-31

19. Virmani R, Burke AP, Farb A, Kolodgie FD. Pathology of the unstable plaque. Progress in cardiovascular diseases. 2002;44:349-356

20. Virmani R, Kolodgie FD, Burke AP, Farb A, Schwartz SM. Lessons from sudden coronary death: A comprehensive morphological classification scheme for atherosclerotic lesions. Arteriosclerosis, thrombosis, and vascular biology. 2000;20:1262-1275

21. Frostegard J, Ulfgren AK, Nyberg P, Hedin U, Swedenborg J, Andersson U, Hansson GK. Cytokine expression in advanced human atherosclerotic plaques: Dominance of pro- 
inflammatory (th1) and macrophage-stimulating cytokines. Atherosclerosis. 1999;145:33-43

22. Mallat $Z$, Taleb $S$, Ait-Oufella $H$, Tedgui $A$. The role of adaptive $t$ cell immunity in atherosclerosis. Journal of lipid research. 2009;50 Suppl:S364-369

23. McLaren JE, Ramji DP. Interferon gamma: A master regulator of atherosclerosis. Cytokine \& growth factor reviews. 2009;20:125-135

24. Amento EP, Ehsani N, Palmer H, Libby P. Cytokines and growth factors positively and negatively regulate interstitial collagen gene expression in human vascular smooth muscle cells. Arteriosclerosis and thrombosis : a journal of vascular biology / American Heart Association. 1991;11:1223-1230

25. Hansson GK, Hellstrand M, Rymo L, Rubbia L, Gabbiani G. Interferon gamma inhibits both proliferation and expression of differentiation-specific alpha-smooth muscle actin in arterial smooth muscle cells. The Journal of experimental medicine. 1989;170:15951608

26. Zhao Z, Wu Y, Cheng M, Ji Y, Yang X, Liu P, Jia S, Yuan Z. Activation of th17/th1 and th1, but not th17, is associated with the acute cardiac event in patients with acute coronary syndrome. Atherosclerosis. 2011;217:518-524

27. Methe H, Brunner S, Wiegand D, Nabauer M, Koglin J, Edelman ER. Enhanced t-helper1 lymphocyte activation patterns in acute coronary syndromes. Journal of the American College of Cardiology. 2005;45:1939-1945

28. Buono C, Binder CJ, Stavrakis G, Witztum JL, Glimcher LH, Lichtman AH. T-bet deficiency reduces atherosclerosis and alters plaque antigen-specific immune responses. Proceedings of the National Academy of Sciences of the United States of America. 2005;102:1596-1601

29. Gupta S, Pablo AM, Jiang X, Wang N, Tall AR, Schindler C. Ifn-gamma potentiates atherosclerosis in apoe knock-out mice. The Journal of clinical investigation. 1997; 99:2752-2761

30. Tenger C, Sundborger A, Jawien J, Zhou X. II-18 accelerates atherosclerosis accompanied by elevation of ifn-gamma and cxcl16 expression independently of $t$ cells. Arteriosclerosis, thrombosis, and vascular biology. 2005;25:791-796

31. Whitman SC, Ravisankar P, Daugherty A. Interleukin-18 enhances atherosclerosis in apolipoprotein e(-/-) mice through release of interferon-gamma. Circulation research. 2002;90:E34-38

32. Whitman SC, Ravisankar P, Elam H, Daugherty A. Exogenous interferon-gamma enhances atherosclerosis in apolipoprotein e-/- mice. The American journal of pathology. 2000;157:1819-1824

33. Lee TS, Yen HC, Pan CC, Chau LY. The role of interleukin 12 in the development of atherosclerosis in apoe-deficient mice. Arteriosclerosis, thrombosis, and vascular biology. 1999;19:734-742

34. Elhage R, Jawien J, Rudling M, Ljunggren HG, Takeda K, Akira S, Bayard F, Hansson GK. Reduced atherosclerosis in interleukin-18 deficient apolipoprotein e-knockout mice. Cardiovascular research. 2003;59:234-240

35. Binder CJ, Hartvigsen K, Chang MK, Miller M, Broide D, Palinski W, Curtiss LK, Corr M, Witztum JL. Il-5 links adaptive and natural immunity specific for epitopes of oxidized Idl and protects from atherosclerosis. The Journal of clinical investigation. 2004;114:427437

36. Cardilo-Reis L, Gruber S, Schreier SM, Drechsler M, Papac-Milicevic N, Weber C, Wagner O, Stangl H, Soehnlein O, Binder CJ. Interleukin-13 protects from atherosclerosis and modulates plaque composition by skewing the macrophage phenotype. EMBO molecular medicine. 2012;4:1072-1086 
37. Caligiuri G, Rudling M, Ollivier V, Jacob MP, Michel JB, Hansson GK, Nicoletti A. Interleukin-10 deficiency increases atherosclerosis, thrombosis, and low-density lipoproteins in apolipoprotein e knockout mice. Molecular medicine. 2003;9:10-17

38. King VL, Cassis LA, Daugherty A. Interleukin-4 does not influence development of hypercholesterolemia or angiotensin ii-induced atherosclerotic lesions in mice. The American journal of pathology. 2007;171:2040-2047

39. Davenport P, Tipping PG. The role of interleukin-4 and interleukin-12 in the progression of atherosclerosis in apolipoprotein e-deficient mice. The American journal of pathology. 2003;163:1117-1125

40. King VL, Szilvassy SJ, Daugherty A. Interleukin-4 deficiency decreases atherosclerotic lesion formation in a site-specific manner in female Idl receptor-/- mice. Arteriosclerosis, thrombosis, and vascular biology. 2002;22:456-461

41. Erbel C, Dengler TJ, Wangler S, Lasitschka F, Bea F, Wambsganss N, Hakimi M, Bockler D, Katus HA, Gleissner CA. Expression of il-17a in human atherosclerotic lesions is associated with increased inflammation and plaque vulnerability. Basic research in cardiology. 2011;106:125-134

42. Eid RE, Rao DA, Zhou J, Lo SF, Ranjbaran H, Gallo A, Sokol SI, Pfau S, Pober JS, Tellides G. Interleukin-17 and interferon-gamma are produced concomitantly by human coronary artery-infiltrating $\mathrm{t}$ cells and act synergistically on vascular smooth muscle cells. Circulation. 2009;119:1424-1432

43. Smith E, Prasad KM, Butcher M, Dobrian A, Kolls JK, Ley K, Galkina E. Blockade of interleukin-17a results in reduced atherosclerosis in apolipoprotein e-deficient mice. Circulation. 2010;121:1746-1755

44. Xie JJ, Wang J, Tang TT, Chen J, Gao XL, Yuan J, Zhou ZH, Liao MY, Yao R, Yu X, Wang D, Cheng $Y$, Liao $Y H$, Cheng $X$. The th17/treg functional imbalance during atherogenesis in apoe(-/-) mice. Cytokine. 2010;49:185-193

45. Butcher MJ, Gjurich BN, Phillips T, Galkina EV. The il-17a/il-17ra axis plays a proatherogenic role via the regulation of aortic myeloid cell recruitment. Circulation research. 2012;110:675-687

46. Ng HP, Burris RL, Nagarajan S. Attenuated atherosclerotic lesions in apoe-fcgammachain-deficient hyperlipidemic mouse model is associated with inhibition of th17 cells and promotion of regulatory t cells. Journal of immunology. 2011;187:6082-6093

47. Gao Q, Jiang Y, Ma T, Zhu F, Gao F, Zhang P, Guo C, Wang Q, Wang X, Ma C, Zhang Y, Chen $W$, Zhang L. A critical function of th17 proinflammatory cells in the development of atherosclerotic plaque in mice. Journal of immunology. 2010;185:5820-5827

48. Erbel C, Chen L, Bea F, Wangler S, Celik S, Lasitschka F, Wang Y, Bockler D, Katus HA, Dengler TJ. Inhibition of il-17a attenuates atherosclerotic lesion development in apoedeficient mice. Journal of immunology. 2009;183:8167-8175

49. van Es $T$, van Puijvelde GH, Ramos $O H$, Segers FM, Joosten LA, van den Berg WB, Michon IM, de Vos P, van Berkel TJ, Kuiper J. Attenuated atherosclerosis upon il-17r signaling disruption in Idlr deficient mice. Biochemical and biophysical research communications. 2009;388:261-265

50. Pejnovic N, Vratimos A, Lee SH, Popadic D, Takeda K, Akira S, Chan WL. Increased atherosclerotic lesions and th17 in interleukin-18 deficient apolipoprotein e-knockout mice fed high-fat diet. Molecular immunology. 2009;47:37-45

51. Danzaki K, Matsui $Y$, Ikesue $M$, Ohta D, Ito K, Kanayama M, Kurotaki D, Morimoto J, Iwakura Y, Yagita H, Tsutsui H, Uede T. Interleukin-17a deficiency accelerates unstable atherosclerotic plaque formation in apolipoprotein e-deficient mice. Arteriosclerosis, thrombosis, and vascular biology. 2012;32:273-280

52. Taleb S, Romain M, Ramkhelawon B, Uyttenhove C, Pasterkamp G, Herbin O, Esposito B, Perez N, Yasukawa H, Van Snick J, Yoshimura A, Tedgui A, Mallat Z. Loss of socs3 
expression in t cells reveals a regulatory role for interleukin-17 in atherosclerosis. The Journal of experimental medicine. 2009;206:2067-2077

53. Maganto-Garcia E, Bu DX, Tarrio ML, Alcaide P, Newton G, Griffin GK, Croce KJ, Luscinskas FW, Lichtman AH, Grabie N. Foxp3+-inducible regulatory t cells suppress endothelial activation and leukocyte recruitment. Journal of immunology. 2011;187:3521-3529

54. Maganto-Garcia E, Tarrio ML, Grabie N, Bu DX, Lichtman AH. Dynamic changes in regulatory $t$ cells are linked to levels of diet-induced hypercholesterolemia. Circulation. 2011;124:185-195

55. van Es T, van Puijvelde GH, Foks AC, Habets KL, Bot I, Gilboa E, Van Berkel TJ, Kuiper J. Vaccination against foxp3(+) regulatory $t$ cells aggravates atherosclerosis. Atherosclerosis. 2010;209:74-80

56. Sasaki N, Yamashita T, Takeda M, Shinohara M, Nakajima K, Tawa H, Usui T, Hirata K. Oral anti-cd3 antibody treatment induces regulatory $t$ cells and inhibits the development of atherosclerosis in mice. Circulation. 2009;120:1996-2005

57. Gotsman I, Gupta R, Lichtman AH. The influence of the regulatory t lymphocytes on atherosclerosis. Arteriosclerosis, thrombosis, and vascular biology. 2007;27:2493-2495

58. Mor A, Planer D, Luboshits G, Afek A, Metzger S, Chajek-Shaul T, Keren G, George J. Role of naturally occurring $c d 4+c d 25+$ regulatory $t$ cells in experimental atherosclerosis. Arteriosclerosis, thrombosis, and vascular biology. 2007;27:893-900

59. Ait-Oufella H, Salomon BL, Potteaux S, Robertson AK, Gourdy P, Zoll J, Merval R, Esposito B, Cohen JL, Fisson S, Flavell RA, Hansson GK, Klatzmann D, Tedgui A, Mallat Z. Natural regulatory t cells control the development of atherosclerosis in mice. Nature medicine. 2006;12:178-180

60. Gotsman I, Grabie N, Gupta R, Dacosta R, MacConmara M, Lederer J, Sukhova G, Witztum JL, Sharpe AH, Lichtman AH. Impaired regulatory t-cell response and enhanced atherosclerosis in the absence of inducible costimulatory molecule. Circulation. 2006;114:2047-2055

61. Mallat Z, Gojova A, Brun V, Esposito B, Fournier N, Cottrez F, Tedgui A, Groux H. Induction of a regulatory $t$ cell type 1 response reduces the development of atherosclerosis in apolipoprotein e-knockout mice. Circulation. 2003;108:1232-1237

62. Potteaux S, Esposito B, van Oostrom O, Brun V, Ardouin P, Groux H, Tedgui A, Mallat Z. Leukocyte-derived interleukin 10 is required for protection against atherosclerosis in low-density lipoprotein receptor knockout mice. Arteriosclerosis, thrombosis, and vascular biology. 2004;24:1474-1478

63. Pinderski LJ, Fischbein MP, Subbanagounder G, Fishbein MC, Kubo N, Cheroutre $H$, Curtiss LK, Berliner JA, Boisvert WA. Overexpression of interleukin-10 by activated $t$ lymphocytes inhibits atherosclerosis in Idl receptor-deficient mice by altering lymphocyte and macrophage phenotypes. Circulation research. 2002;90:1064-1071

64. Lutgens $E$, Gijbels $M$, Smook M, Heeringa $P$, Gotwals $P$, Koteliansky VE, Daemen MJ. Transforming growth factor-beta mediates balance between inflammation and fibrosis during plaque progression. Arteriosclerosis, thrombosis, and vascular biology. 2002;22:975-982

65. Mallat Z, Gojova A, Marchiol-Fournigault C, Esposito B, Kamate C, Merval R, Fradelizi D, Tedgui A. Inhibition of transforming growth factor-beta signaling accelerates atherosclerosis and induces an unstable plaque phenotype in mice. Circulation research. 2001;89:930-934

66. Mallat Z, Besnard S, Duriez M, Deleuze V, Emmanuel F, Bureau MF, Soubrier F, Esposito B, Duez H, Fievet C, Staels B, Duverger N, Scherman D, Tedgui A. Protective role of interleukin-10 in atherosclerosis. Circulation research. 1999;85:e17-24 
67. Grainger DJ, Kemp PR, Metcalfe JC, Liu AC, Lawn RM, Williams NR, Grace AA, Schofield $\mathrm{PM}$, Chauhan $\mathrm{A}$. The serum concentration of active transforming growth factor-beta is severely depressed in advanced atherosclerosis. Nature medicine. 1995;1:74-79

68. Feng J, Zhang Z, Kong W, Liu B, Xu Q, Wang X. Regulatory $t$ cells ameliorate hyperhomocysteinaemia-accelerated atherosclerosis in apoe-/- mice. Cardiovascular research. 2009;84:155-163

69. Rao A, Luo C, Hogan PG. Transcription factors of the nfat family: Regulation and function. Annual review of immunology. 1997;15:707-747

70. Macian F. Nfat proteins: Key regulators of t-cell development and function. Nature reviews. Immunology. 2005;5:472-484

71. Hermann-Kleiter N, Baier G. Nfat pulls the strings during cd4t thelper cell effector functions. Blood. 2010;115:2989-2997

72. Torgerson TR, Genin A, Chen C, Zhang M, Zhou B, Anover-Sombke S, Frank MB, Dozmorov I, Ocheltree E, Kulmala P, Centola M, Ochs HD, Wells AD, Cron RQ. Foxp3 inhibits activation-induced nfat2 expression in t cells thereby limiting effector cytokine expression. Journal of immunology. 2009;183:907-915

73. Sumpter TL, Payne KK, Wilkes DS. Regulation of the nfat pathway discriminates $\mathrm{cd} 4+\mathrm{cd} 25+$ regulatory $\mathrm{t}$ cells from $\mathrm{cd} 4+\mathrm{cd} 25-$ helper $\mathrm{t}$ cells. Journal of leukocyte biology. 2008;83:708-717

74. Wu Y, Borde M, Heissmeyer V, Feuerer M, Lapan AD, Stroud JC, Bates DL, Guo L, Han A, Ziegler SF, Mathis D, Benoist C, Chen L, Rao A. Foxp3 controls regulatory t cell function through cooperation with nfat. Cell. 2006;126:375-387

75. Rengarajan J, Tang B, Glimcher LH. Nfatc2 and nfatc3 regulate $t(h) 2$ differentiation and

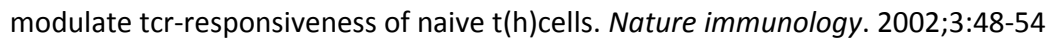

76. Kiani A, Garcia-Cozar FJ, Habermann I, Laforsch S, Aebischer T, Ehninger G, Rao A. Regulation of interferon-gamma gene expression by nuclear factor of activated $t$ cells. Blood. 2001;98:1480-1488

77. Ranger AM, Oukka M, Rengarajan J, Glimcher LH. Inhibitory function of two nfat family members in lymphoid homeostasis and th2 development. Immunity. 1998;9:627-635

78. Kiani A, Viola JP, Lichtman AH, Rao A. Down-regulation of il-4 gene transcription and control of th2 cell differentiation by a mechanism involving nfat1. Immunity. 1997;7:849-860

79. Hodge MR, Ranger AM, Charles de la Brousse F, Hoey T, Grusby MJ, Glimcher LH. Hyperproliferation and dysregulation of il-4 expression in nf-atp-deficient mice. Immunity. 1996;4:397-405

80. Ghosh S, Koralov SB, Stevanovic I, Sundrud MS, Sasaki Y, Rajewsky K, Rao A, Muller MR. Hyperactivation of nuclear factor of activated t cells 1 (nfat1) in t cells attenuates severity of murine autoimmune encephalomyelitis. Proceedings of the National Academy of Sciences of the United States of America. 2010;107:15169-15174

81. Weigmann B, Lehr HA, Yancopoulos G, Valenzuela D, Murphy A, Stevens S, Schmidt J, Galle PR, Rose-John S, Neurath MF. The transcription factor nfatc2 controls il-6dependent $\mathrm{t}$ cell activation in experimental colitis. The Journal of experimental medicine. 2008;205:2099-2110

82. Yoshida $H$, Nishina $H$, Takimoto $H$, Marengere LE, Wakeham AC, Bouchard D, Kong YY, Ohteki T, Shahinian A, Bachmann M, Ohashi PS, Penninger JM, Crabtree GR, Mak TW. The transcription factor nf-atc1 regulates lymphocyte proliferation and th2 cytokine production. Immunity. 1998;8:115-124

83. Ranger AM, Hodge MR, Gravallese EM, Oukka M, Davidson L, Alt FW, de la Brousse FC, Hoey T, Grusby M, Glimcher LH. Delayed lymphoid repopulation with defects in il-4driven responses produced by inactivation of nf-atc. Immunity. 1998;8:125-134 
84. Galper SL, Yu JB, Mauch PM, Strasser JF, Silver B, Lacasce A, Marcus KJ, Stevenson MA, Chen $\mathrm{MH}, \mathrm{Ng} A K$. Clinically significant cardiac disease in patients with hodgkin lymphoma treated with mediastinal irradiation. Blood. 2011;117:412-418

85. Swerdlow AJ, Higgins CD, Smith $P$, Cunningham D, Hancock BW, Horwich A, Hoskin PJ, Lister A, Radford JA, Rohatiner AZ, Linch DC. Myocardial infarction mortality risk after treatment for hodgkin disease: A collaborative british cohort study. Journal of the National Cancer Institute. 2007;99:206-214

86. Bowers DC, McNeil DE, Liu Y, Yasui Y, Stovall M, Gurney JG, Hudson MM, Donaldson SS, Packer RJ, Mitby PA, Kasper CE, Robison LL, Oeffinger KC. Stroke as a late treatment effect of hodgkin's disease: A report from the childhood cancer survivor study. Journal of clinical oncology : official journal of the American Society of Clinical Oncology. 2005;23:6508-6515

87. Adams MJ, Lipsitz SR, Colan SD, Tarbell NJ, Treves ST, Diller L, Greenbaum N, Mauch P, Lipshultz SE. Cardiovascular status in long-term survivors of hodgkin's disease treated with chest radiotherapy. Journal of clinical oncology : official journal of the American Society of Clinical Oncology. 2004;22:3139-3148

88. Hull MC, Morris CG, Pepine CJ, Mendenhall NP. Valvular dysfunction and carotid, subclavian, and coronary artery disease in survivors of hodgkin lymphoma treated with radiation therapy. JAMA : the journal of the American Medical Association. 2003;290:2831-2837

89. Adams MJ, Lipshultz SE, Schwartz C, Fajardo LF, Coen V, Constine LS. Radiationassociated cardiovascular disease: Manifestations and management. Seminars in radiation oncology. 2003;13:346-356

90. Aleman BM, van den Belt-Dusebout AW, Klokman WJ, Van't Veer MB, Bartelink H, van Leeuwen FE. Long-term cause-specific mortality of patients treated for hodgkin's disease. Journal of clinical oncology : official journal of the American Society of Clinical Oncology. 2003;21:3431-3439

91. Hancock SL, Tucker MA, Hoppe RT. Factors affecting late mortality from heart disease after treatment of hodgkin's disease. JAMA : the journal of the American Medical Association. 1993;270:1949-1955

92. Boivin JF, Hutchison GB, Lubin JH, Mauch P. Coronary artery disease mortality in patients treated for hodgkin's disease. Cancer. 1992;69:1241-1247

93. Hooning MJ, Botma A, Aleman BM, Baaijens MH, Bartelink H, Klijn JG, Taylor CW, van Leeuwen FE. Long-term risk of cardiovascular disease in 10-year survivors of breast cancer. Journal of the National Cancer Institute. 2007;99:365-375

94. Senkus-Konefka E, Jassem J. Cardiovascular effects of breast cancer radiotherapy. Cancer treatment reviews. 2007;33:578-593

95. Taylor CW, Nisbet A, McGale P, Darby SC. Cardiac exposures in breast cancer radiotherapy: 1950s-1990s. International journal of radiation oncology, biology, physics. 2007;69:1484-1495

96. Darby SC, McGale P, Taylor CW, Peto R. Long-term mortality from heart disease and lung cancer after radiotherapy for early breast cancer: Prospective cohort study of about 300,000 women in us seer cancer registries. The lancet oncology. 2005;6:557565

97. Gaya AM, Ashford RF. Cardiac complications of radiation therapy. Clinical oncology. 2005;17:153-159

98. Paszat LF, Mackillop WJ, Groome PA, Boyd C, Schulze K, Holowaty E. Mortality from myocardial infarction after adjuvant radiotherapy for breast cancer in the surveillance, epidemiology, and end-results cancer registries. Journal of clinical oncology : official journal of the American Society of Clinical Oncology. 1998;16:2625-2631 
99. Gyenes G, Rutqvist LE, Liedberg A, Fornander T. Long-term cardiac morbidity and mortality in a randomized trial of pre- and postoperative radiation therapy versus surgery alone in primary breast cancer. Radiotherapy and oncology : journal of the European Society for Therapeutic Radiology and Oncology. 1998;48:185-190

100. Chu CN, Chen SW, Bai LY, Mou CH, Hsu CY, Sung FC. Increase in stroke risk in patients with head and neck cancer: A retrospective cohort study. British journal of cancer. 2011;105:1419-1423

101. Dorresteijn LD, Kappelle AC, Boogerd W, Klokman WJ, Balm AJ, Keus RB, van Leeuwen $\mathrm{FE}$, Bartelink $\mathrm{H}$. Increased risk of ischemic stroke after radiotherapy on the neck in patients younger than 60 years. Journal of clinical oncology : official journal of the American Society of Clinical Oncology. 2002;20:282-288

102. Aleman $B M$, van den Belt-Dusebout AW, De Bruin $M L$, van 't Veer $M B$, Baaijens $M H$, de Boer JP, Hart AA, Klokman WJ, Kuenen MA, Ouwens GM, Bartelink H, van Leeuwen FE. Late cardiotoxicity after treatment for hodgkin lymphoma. Blood. 2007;109:1878-1886

103. Clarke M, Collins R, Darby S, Davies C, Elphinstone P, Evans E, Godwin J, Gray R, Hicks C, James S, Mackinnon E, McGale P, McHugh T, Peto R, Taylor C, Wang Y, Early Breast Cancer Trialists' Collaborative G. Effects of radiotherapy and of differences in the extent of surgery for early breast cancer on local recurrence and 15-year survival: An overview of the randomised trials. Lancet. 2005;366:2087-2106

104. Early Breast Cancer Trialists' Collaborative G. Favourable and unfavourable effects on long-term survival of radiotherapy for early breast cancer: An overview of the randomised trials. Early breast cancer trialists' collaborative group. Lancet. 2000;355:1757-1770

105. Darby SC, Cutter DJ, Boerma M, Constine LS, Fajardo LF, Kodama K, Mabuchi K, Marks LB, Mettler FA, Pierce LJ, Trott KR, Yeh ET, Shore RE. Radiation-related heart disease: Current knowledge and future prospects. International journal of radiation oncology, biology, physics. 2010;76:656-665

106. Darby SC, Ewertz M, McGale P, Bennet AM, Blom-Goldman U, Bronnum D, Correa C, Cutter D, Gagliardi G, Gigante B, Jensen MB, Nisbet A, Peto R, Rahimi K, Taylor C, Hall $P$. Risk of ischemic heart disease in women after radiotherapy for breast cancer. The New England journal of medicine. 2013;368:987-998

107. McGale P, Darby SC, Hall P, Adolfsson J, Bengtsson NO, Bennet AM, Fornander T, Gigante B, Jensen MB, Peto R, Rahimi K, Taylor CW, Ewertz M. Incidence of heart disease in 35,000 women treated with radiotherapy for breast cancer in denmark and sweden. Radiotherapy and oncology : journal of the European Society for Therapeutic Radiology and Oncology. 2011;100:167-175

108. Virmani R, Farb A, Carter AJ, Jones RM. Pathology of radiation-induced coronary artery disease in human and pig. Cardiovascular radiation medicine. 1999;1:98-101

109. O'Leary DH, Polak JF, Kronmal RA, Manolio TA, Burke GL, Wolfson SK, Jr. Carotid-artery intima and media thickness as a risk factor for myocardial infarction and stroke in older adults. Cardiovascular health study collaborative research group. The New England journal of medicine. 1999;340:14-22

110. Bots ML, Hoes AW, Koudstaal PJ, Hofman A, Grobbee DE. Common carotid intimamedia thickness and risk of stroke and myocardial infarction: The rotterdam study. Circulation. 1997;96:1432-1437

111. Russell NS, Hoving S, Heeneman S, Hage JJ, Woerdeman LA, de Bree R, Lohuis PJ, Smeele L, Cleutjens J, Valenkamp A, Dorresteijn LD, Dalesio O, Daemen MJ, Stewart FA. Novel insights into pathological changes in muscular arteries of radiotherapy patients. Radiotherapy and oncology : journal of the European Society for Therapeutic Radiology and Oncology. 2009;92:477-483 
112. Dorresteijn LD, Kappelle AC, Scholz NM, Munneke M, Scholma JT, Balm AJ, Bartelink H, Boogerd W. Increased carotid wall thickening after radiotherapy on the neck. European journal of cancer. 2005;41:1026-1030

113. Cheng SW, Ting AC, Ho P, Wu LL. Accelerated progression of carotid stenosis in patients with previous external neck irradiation. Journal of vascular surgery. 2004;39:409-415

114. Muzaffar K, Collins SL, Labropoulos N, Baker WH. A prospective study of the effects of irradiation on the carotid artery. The Laryngoscope. 2000;110:1811-1814

115. Van Der Meeren A, Squiban C, Gourmelon P, Lafont H, Gaugler MH. Differential regulation by il- 4 and il-10 of radiation-induced il- 6 and il- 8 production and icam-1 expression by human endothelial cells. Cytokine. 1999;11:831-838

116. Quarmby S, Kumar P, Kumar S. Radiation-induced normal tissue injury: Role of adhesion molecules in leukocyte-endothelial cell interactions. International journal of cancer. Journal international du cancer. 1999;82:385-395

117. Hallahan D, Kuchibhotla J, Wyble C. Cell adhesion molecules mediate radiationinduced leukocyte adhesion to the vascular endothelium. Cancer research. 1996;56:5150-5155

118. Hallahan D, Clark ET, Kuchibhotla J, Gewertz BL, Collins T. E-selectin gene induction by ionizing radiation is independent of cytokine induction. Biochemical and biophysical research communications. 1995;217:784-795

119. Molla M, Gironella M, Miquel R, Tovar V, Engel P, Biete A, Pique JM, Panes J. Relative roles of icam-1 and vcam-1 in the pathogenesis of experimental radiation-induced intestinal inflammation. International journal of radiation oncology, biology, physics. 2003;57:264-273

120. Quarmby S, Hunter RD, Kumar S. Irradiation induced expression of cd31, icam-1 and vcam-1 in human microvascular endothelial cells. Anticancer research. 2000;20:33753381

121. Heckmann M, Douwes K, Peter R, Degitz K. Vascular activation of adhesion molecule mrna and cell surface expression by ionizing radiation. Experimental cell research. 1998;238:148-154

122. Hallahan DE, Virudachalam S, Kuchibhotla J. Nuclear factor kappab dominant negative genetic constructs inhibit $x$-ray induction of cell adhesion molecules in the vascular endothelium. Cancer research. 1998;58:5484-5488

123. Baeuml H, Behrends U, Peter RU, Mueller S, Kammerbauer C, Caughman SW, Degitz K. Ionizing radiation induces, via generation of reactive oxygen intermediates, intercellular adhesion molecule-1 (icam-1) gene transcription and nf kappa b-like binding activity in the icam-1 transcriptional regulatory region. Free radical research. 1997;27:127-142

124. Hallahan DE, Virudachalam S. Intercellular adhesion molecule 1 knockout abrogates radiation induced pulmonary inflammation. Proceedings of the National Academy of Sciences of the United States of America. 1997;94:6432-6437

125. Gaugler MH, Squiban C, van der Meeren A, Bertho JM, Vandamme M, Mouthon MA. Late and persistent up-regulation of intercellular adhesion molecule-1 (icam-1) expression by ionizing radiation in human endothelial cells in vitro. International journal of radiation biology. 1997;72:201-209

126. Boerma M, Kruse JJ, van Loenen M, Klein HR, Bart Cl, Zurcher C, Wondergem J. Increased deposition of von willebrand factor in the rat heart after local ionizing irradiation. Strahlentherapie und Onkologie : Organ der Deutschen Rontgengesellschaft ... [et al]. 2004;180:109-116

127. Wang J, Zheng $H, O u$ X, Fink LM, Hauer-Jensen M. Deficiency of microvascular thrombomodulin and up-regulation of protease-activated receptor-1 in irradiated rat 
intestine: Possible link between endothelial dysfunction and chronic radiation fibrosis. The American journal of pathology. 2002;160:2063-2072

128. te Poele JA, van Kleef EM, van der Wal AF, Dewit LG, Stewart FA. Radiation-induced glomerular thrombus formation and nephropathy are not prevented by the adp receptor antagonist clopidogrel. International journal of radiation oncology, biology, physics. 2001;50:1332-1338

129. van Kleef E, Verheij M, te Poele H, Oussoren $Y$, Dewit $L$, Stewart F. In vitro and in vivo expression of endothelial von willebrand factor and leukocyte accumulation after fractionated irradiation. Radiation research. 2000;154:375-381

130. Verheij M, Dewit LG, Boomgaard MN, Brinkman HJ, van Mourik JA. Ionizing radiation enhances platelet adhesion to the extracellular matrix of human endothelial cells by an increase in the release of von willebrand factor. Radiation research. 1994;137:202-207

131. Paris F, Fuks Z, Kang A, Capodieci P, Juan G, Ehleiter D, Haimovitz-Friedman A, CordonCardo C, Kolesnick R. Endothelial apoptosis as the primary lesion initiating intestinal radiation damage in mice. Science. 2001;293:293-297

132. Langley RE, Bump EA, Quartuccio SG, Medeiros D, Braunhut SJ. Radiation-induced apoptosis in microvascular endothelial cells. British journal of cancer. 1997;75:666-672

133. Hoving S, Heeneman S, Gijbels MJ, te Poele JA, Russell NS, Daemen MJ, Stewart FA. Single-dose and fractionated irradiation promote initiation and progression of atherosclerosis and induce an inflammatory plaque phenotype in apoe(-/-) mice. International journal of radiation oncology, biology, physics. 2008;71:848-857

134. Stewart FA, Heeneman S, Te Poele J, Kruse J, Russell NS, Gijbels M, Daemen M. Ionizing radiation accelerates the development of atherosclerotic lesions in apoe-/- mice and predisposes to an inflammatory plaque phenotype prone to hemorrhage. The American journal of pathology. 2006;168:649-658

135. Pakala R, Leborgne L, Cheneau E, Chan RC, Yazdi H, Fournadjiev J, Weber D, Hellinga D, Kolodgie F, Virmani R, Waksman R. Radiation-induced atherosclerotic plaque progression in a hypercholesterolemic rabbit: A prospective vulnerable plaque model? Cardiovascular radiation medicine. 2003;4:146-151

136. Schiller NK, Kubo N, Boisvert WA, Curtiss LK. Effect of gamma-irradiation and bone marrow transplantation on atherosclerosis in Idl receptor-deficient mice. Arteriosclerosis, thrombosis, and vascular biology. 2001;21:1674-1680

137. Hayashi T, Kusunoki Y, Hakoda M, Morishita Y, Kubo Y, Maki M, Kasagi F, Kodama K, Macphee DG, Kyoizumi S. Radiation dose-dependent increases in inflammatory response markers in a-bomb survivors. International journal of radiation biology. 2003;79:129-136

138. Baker JE, Fish BL, Su J, Haworth ST, Strande JL, Komorowski RA, Migrino RQ, Doppalapudi A, Harmann L, Allen Li X, Hopewell JW, Moulder JE. 10 gy total body irradiation increases risk of coronary sclerosis, degeneration of heart structure and function in a rat model. International journal of radiation biology. 2009;85:1089-1100

139. Wong FL, Yamada M, Sasaki H, Kodama K, Hosoda Y. Effects of radiation on the longitudinal trends of total serum cholesterol levels in the atomic bomb survivors. Radiation research. 1999;151:736-746

140. Sasaki H, Wong FL, Yamada M, Kodama K. The effects of aging and radiation exposure on blood pressure levels of atomic bomb survivors. Journal of clinical epidemiology. 2002;55:974-981

141. Adams MJ, Grant EJ, Kodama K, Shimizu Y, Kasagi F, Suyama A, Sakata R, Akahoshi M. Radiation dose associated with renal failure mortality: A potential pathway to partially explain increased cardiovascular disease mortality observed after whole-body irradiation. Radiation research. 2012;177:220-228 
142. Emerging Risk Factors C, Kaptoge S, Di Angelantonio E, Lowe G, Pepys MB, Thompson SG, Collins R, Danesh J. C-reactive protein concentration and risk of coronary heart disease, stroke, and mortality: An individual participant meta-analysis. Lancet. 2010;375:132-140

143. Shimizu $Y$, Kodama K, Nishi N, Kasagi $F$, Suyama A, Soda M, Grant EJ, Sugiyama $H$, Sakata R, Moriwaki $H$, Hayashi $M$, Konda $M$, Shore RE. Radiation exposure and circulatory disease risk: Hiroshima and nagasaki atomic bomb survivor data, 19502003. Bmj. 2010;340:b5349

144. Frantz S, Ertl G, Bauersachs J. Mechanisms of disease: Toll-like receptors in cardiovascular disease. Nature clinical practice. Cardiovascular medicine. 2007;4:444454

145. Hei TK, Zhou H, Chai Y, Ponnaiya B, Ivanov VN. Radiation induced non-targeted response: Mechanism and potential clinical implications. Current molecular pharmacology. 2011;4:96-105

146. Harada T, Kashino G, Suzuki K, Matsuda N, Kodama S, Watanabe M. Different involvement of radical species in irradiated and bystander cells. International journal of radiation biology. 2008;84:809-814

147. Narayanan PK, Goodwin EH, Lehnert BE. Alpha particles initiate biological production of superoxide anions and hydrogen peroxide in human cells. Cancer research. 1997;57:3963-3971

148. Narayanan PK, LaRue KE, Goodwin EH, Lehnert BE. Alpha particles induce the production of interleukin-8 by human cells. Radiation research. 1999;152:57-63

149. Gow MD, Seymour CB, Ryan LA, Mothersill CE. Induction of bystander response in human glioma cells using high-energy electrons: A role for tgf-beta1. Radiation research. 2010;173:769-778

150. Shao C, Folkard M, Prise KM. Role of tgf-beta1 and nitric oxide in the bystander response of irradiated glioma cells. Oncogene. 2008;27:434-440

151. Iyer $R$, Lehnert $B E$, Svensson R. Factors underlying the cell growth-related bystander responses to alpha particles. Cancer research. 2000;60:1290-1298

152. Luce A, Courtin A, Levalois C, Altmeyer-Morel S, Romeo PH, Chevillard S, Lebeau J. Death receptor pathways mediate targeted and non-targeted effects of ionizing radiations in breast cancer cells. Carcinogenesis. 2009;30:432-439

153. Mothersill C, Seymour C. Medium from irradiated human epithelial cells but not human fibroblasts reduces the clonogenic survival of unirradiated cells. International journal of radiation biology. 1997;71:421-427

154. Watson GE, Lorimore SA, Macdonald DA, Wright EG. Chromosomal instability in unirradiated cells induced in vivo by a bystander effect of ionizing radiation. Cancer research. 2000;60:5608-5611

155. Wright EG. Radiation-induced genomic instability in haemopoietic cells. International journal of radiation biology. 1998;74:681-687

156. Morgan WF, Day JP, Kaplan MI, McGhee EM, Limoli CL. Genomic instability induced by ionizing radiation. Radiation research. 1996;146:247-258

157. Lehnert BE, Goodwin EH, Deshpande A. Extracellular factor(s) following exposure to alpha particles can cause sister chromatid exchanges in normal human cells. Cancer research. 1997;57:2164-2171

158. Lorimore SA, Kadhim MA, Pocock DA, Papworth D, Stevens DL, Goodhead DT, Wright EG. Chromosomal instability in the descendants of unirradiated surviving cells after alpha-particle irradiation. Proceedings of the National Academy of Sciences of the United States of America. 1998;95:5730-5733 
159. Ivanov VN, Zhou H, Ghandhi SA, Karasic TB, Yaghoubian B, Amundson SA, Hei TK. Radiation-induced bystander signaling pathways in human fibroblasts: A role for interleukin-33 in the signal transmission. Cellular signalling. 2010;22:1076-1087

160. Ghandhi SA, Ming L, Ivanov VN, Hei TK, Amundson SA. Regulation of early signaling and gene expression in the alpha-particle and bystander response of imr-90 human fibroblasts. BMC medical genomics. 2010;3:31

161. Prise KM, Belyakov OV, Folkard M, Michael BD. Studies of bystander effects in human fibroblasts using a charged particle microbeam. International journal of radiation biology. 1998;74:793-798

162. Rzeszowska-Wolny J, Herok R, Widel M, Hancock R. X-irradiation and bystander effects induce similar changes of transcript profiles in most functional pathways in human melanoma cells. DNA repair. 2009;8:732-738

163. Little JB. Lauriston s. Taylor lecture: Nontargeted effects of radiation: Implications for low-dose exposures. Health physics. 2006;91:416-426

164. Azzam El, de Toledo SM, Gooding T, Little JB. Intercellular communication is involved in the bystander regulation of gene expression in human cells exposed to very low fluences of alpha particles. Radiation research. 1998;150:497-504

165. Morgan WF. Non-targeted and delayed effects of exposure to ionizing radiation: li. Radiation-induced genomic instability and bystander effects in vivo, clastogenic factors and transgenerational effects. Radiation research. 2003;159:581-596

166. Lorimore SA, Wright EG. Radiation-induced genomic instability and bystander effects: Related inflammatory-type responses to radiation-induced stress and injury? A review. International journal of radiation biology. 2003;79:15-25

167. Mothersill C, Seymour C. Radiation-induced bystander effects: Past history and future directions. Radiation research. 2001;155:759-767

168. Emerit I. Reactive oxygen species, chromosome mutation, and cancer: Possible role of clastogenic factors in carcinogenesis. Free radical biology \& medicine. 1994;16:99-109

169. Lorimore SA, Chrystal JA, Robinson JI, Coates PJ, Wright EG. Chromosomal instability in unirradiated hemaopoietic cells induced by macrophages exposed in vivo to ionizing radiation. Cancer research. 2008;68:8122-8126

170. Stoneman V, Braganza D, Figg N, Mercer J, Lang R, Goddard M, Bennett $M$. Monocyte/macrophage suppression in $\mathrm{cd} 11 \mathrm{~b}$ diphtheria toxin receptor transgenic mice differentially affects atherogenesis and established plaques. Circulation research. 2007; 100:884-893

171. Smith JD, Trogan E, Ginsberg M, Grigaux C, Tian J, Miyata M. Decreased atherosclerosis in mice deficient in both macrophage colony-stimulating factor (op) and apolipoprotein e. Proceedings of the National Academy of Sciences of the United States of America. 1995;92:8264-8268

172. Swirski FK, Pittet MJ, Kircher MF, Aikawa E, Jaffer FA, Libby P, Weissleder R. Monocyte accumulation in mouse atherogenesis is progressive and proportional to extent of disease. Proceedings of the National Academy of Sciences of the United States of America. 2006;103:10340-10345

173. Martinez FO, Helming L, Milde R, Varin A, Melgert BN, Draijer C, Thomas B, Fabbri M, Crawshaw A, Ho LP, Ten Hacken NH, Cobos Jimenez V, Kootstra NA, Hamann J, Greaves DR, Locati M, Mantovani A, Gordon S. Genetic programs expressed in resting and il-4 alternatively activated mouse and human macrophages: Similarities and differences. Blood. 2013;121:e57-69

174. Hoeksema MA, Stoger JL, de Winther MP. Molecular pathways regulating macrophage polarization: Implications for atherosclerosis. Current atherosclerosis reports. 2012;14:254-263 
175. Lopez-Castejon G, Baroja-Mazo A, Pelegrin P. Novel macrophage polarization model: From gene expression to identification of new anti-inflammatory molecules. Cellular and molecular life sciences : CMLS. 2011;68:3095-3107

176. Gordon S, Martinez FO. Alternative activation of macrophages: Mechanism and functions. Immunity. 2010;32:593-604

177. Classen A, Lloberas J, Celada A. Macrophage activation: Classical versus alternative. Methods in molecular biology. 2009;531:29-43

178. Martinez FO, Helming L, Gordon S. Alternative activation of macrophages: An immunologic functional perspective. Annual review of immunology. 2009;27:451-483

179. Mosser DM, Edwards JP. Exploring the full spectrum of macrophage activation. Nature reviews. Immunology. 2008;8:958-969

180. Martinez FO, Sica A, Mantovani A, Locati M. Macrophage activation and polarization. Frontiers in bioscience : a journal and virtual library. 2008;13:453-461

181. Gordon S. Alternative activation of macrophages. Nature reviews. Immunology. 2003;3:23-35

182. Murray PJ, Wynn TA. Protective and pathogenic functions of macrophage subsets. Nature reviews. Immunology. 2011;11:723-737

183. Murray PJ, Wynn TA. Obstacles and opportunities for understanding macrophage polarization. Journal of leukocyte biology. 2011;89:557-563

184. Martinez FO, Gordon S, Locati M, Mantovani A. Transcriptional profiling of the human monocyte-to-macrophage differentiation and polarization: New molecules and patterns of gene expression. Journal of immunology. 2006;177:7303-7311

185. Raes G, Van den Bergh R, De Baetselier P, Ghassabeh GH, Scotton C, Locati M, Mantovani A, Sozzani S. Arginase-1 and ym1 are markers for murine, but not human, alternatively activated myeloid cells. Journal of immunology. 2005;174:6561; author reply 6561-6562

186. Moore KJ, Tabas I. Macrophages in the pathogenesis of atherosclerosis. Cell. 2011;145:341-355

187. Khallou-Laschet J, Varthaman A, Fornasa G, Compain C, Gaston AT, Clement M, Dussiot M, Levillain O, Graff-Dubois S, Nicoletti A, Caligiuri G. Macrophage plasticity in experimental atherosclerosis. PloS one. 2010;5:e8852

188. Waldo SW, Li Y, Buono C, Zhao B, Billings EM, Chang J, Kruth HS. Heterogeneity of human macrophages in culture and in atherosclerotic plaques. The American journal of pathology. 2008;172:1112-1126

189. Bouhlel MA, Derudas B, Rigamonti E, Dievart R, Brozek J, Haulon S, Zawadzki C, Jude B, Torpier G, Marx N, Staels B, Chinetti-Gbaguidi G. Ppargamma activation primes human monocytes into alternative $\mathrm{m} 2$ macrophages with anti-inflammatory properties. Cell metabolism. 2007;6:137-143

190. Boyle JJ, Johns M, Lo J, Chiodini A, Ambrose N, Evans PC, Mason JC, Haskard DO. Heme induces heme oxygenase 1 via nrf2: Role in the homeostatic macrophage response to intraplaque hemorrhage. Arteriosclerosis, thrombosis, and vascular biology. 2011;31:2685-2691

191. Kadl A, Meher AK, Sharma PR, Lee MY, Doran AC, Johnstone SR, Elliott MR, Gruber F, Han J, Chen W, Kensler T, Ravichandran KS, Isakson BE, Wamhoff BR, Leitinger N. Identification of a novel macrophage phenotype that develops in response to atherogenic phospholipids via nrf2. Circulation research. 2010;107:737-746

192. Boyle JJ, Harrington HA, Piper E, Elderfield K, Stark J, Landis RC, Haskard DO. Coronary intraplaque hemorrhage evokes a novel atheroprotective macrophage phenotype. The American journal of pathology. 2009;174:1097-1108 
193. Gleissner CA, Shaked I, Little KM, Ley K. Cxc chemokine ligand 4 induces a unique transcriptome in monocyte-derived macrophages. Journal of immunology. 2010;184:4810-4818

194. Gleissner CA, Shaked I, Erbel C, Bockler D, Katus HA, Ley K. Cxcl4 downregulates the atheroprotective hemoglobin receptor cd163 in human macrophages. Circulation research. 2010;106:203-211

195. Monceau V, Meziani L, Strup-Perrot C, Morel E, Schmidt M, Haagen J, Escoubet B, Dorr W, Vozenin MC. Enhanced sensitivity to low dose irradiation of apoe-/- mice mediated by early pro-inflammatory profile and delayed activation of the tgfbeta1 cascade involved in fibrogenesis. PloS one. 2013;8:e57052

196. Schultz-Hector S, Trott KR. Radiation-induced cardiovascular diseases: Is the epidemiologic evidence compatible with the radiobiologic data? International journal of radiation oncology, biology, physics. 2007;67:10-18

197. Lauk S, Kiszel Z, Buschmann J, Trott KR. Radiation-induced heart disease in rats. International journal of radiation oncology, biology, physics. 1985;11:801-808

198. Fajardo LF, Stewart JR. Capillary injury preceding radiation-induced myocardial fibrosis. Radiology. 1971;101:429-433

199. Yeung TK, Lauk S, Simmonds RH, Hopewell JW, Trott KR. Morphological and functional changes in the rat heart after $\mathrm{x}$ irradiation: Strain differences. Radiation research. 1989;119:489-499

200. Fajardo LF, Stewart JR. Pathogenesis of radiation-induced myocardial fibrosis. Laboratory investigation; a journal of technical methods and pathology. 1973;29:244257

201. Fajardo LF, Stewart JR. Experimental radiation-induced heart disease. I. Light microscopic studies. The American journal of pathology. 1970;59:299-316

202. Seddon B, Cook A, Gothard L, Salmon E, Latus K, Underwood SR, Yarnold J. Detection of defects in myocardial perfusion imaging in patients with early breast cancer treated with radiotherapy. Radiotherapy and oncology : journal of the European Society for Therapeutic Radiology and Oncology. 2002;64:53-63

203. Gyenes G, Fornander T, Carlens P, Glas U, Rutqvist LE. Myocardial damage in breast cancer patients treated with adjuvant radiotherapy: A prospective study. International journal of radiation oncology, biology, physics. 1996;36:899-905

204. Prosnitz RG, Hubbs JL, Evans ES, Zhou SM, Yu X, Blazing MA, Hollis DR, Tisch A, Wong TZ, Borges-Neto S, Hardenbergh PH, Marks LB. Prospective assessment of radiotherapy-associated cardiac toxicity in breast cancer patients: Analysis of data 3 to 6 years after treatment. Cancer. 2007;110:1840-1850

205. Marks LB, Yu X, Prosnitz RG, Zhou SM, Hardenbergh PH, Blazing M, Hollis D, Lind $P$, Tisch A, Wong TZ, Borges-Neto $S$. The incidence and functional consequences of rtassociated cardiac perfusion defects. International journal of radiation oncology, biology, physics. 2005;63:214-223

206. Schultz-Hector S, Balz K. Radiation-induced loss of endothelial alkaline phosphatase activity and development of myocardial degeneration. An ultrastructural study. Laboratory investigation; a journal of technical methods and pathology. 1994;71:252260

207. Schultz-Hector S. Radiation-induced heart disease: Review of experimental data on dose response and pathogenesis. International journal of radiation biology. 1992;61:149-160

208. Lauk S, Trott KR. Endothelial cell proliferation in the rat heart following local heart irradiation. International journal of radiation biology. 1990;57:1017-1030 
209. Lauk S. Endothelial alkaline phosphatase activity loss as an early stage in the development of radiation-induced heart disease in rats. Radiation research. 1987;110:118-128

210. Nadlonek NA, Weyant MJ, Yu JA, Cleveland JC, Jr., Reece TB, Meng X, Fullerton DA. Radiation induces osteogenesis in human aortic valve interstitial cells. The Journal of thoracic and cardiovascular surgery. 2012;144:1466-1470

211. Yusuf SW, Sami S, Daher IN. Radiation-induced heart disease: A clinical update. Cardiology research and practice. 2011;2011:317659

212. Andratschke N, Maurer J, Molls $M$, Trott KR. Late radiation-induced heart disease after radiotherapy. Clinical importance, radiobiological mechanisms and strategies of prevention. Radiotherapy and oncology : journal of the European Society for Therapeutic Radiology and Oncology. 2011;100:160-166

213. Heidenreich PA, Schnittger I, Strauss HW, Vagelos RH, Lee BK, Mariscal CS, Tate DJ, Horning SJ, Hoppe RT, Hancock SL. Screening for coronary artery disease after mediastinal irradiation for hodgkin's disease. Journal of clinical oncology : official journal of the American Society of Clinical Oncology. 2007;25:43-49

214. Heidenreich PA, Hancock SL, Vagelos RH, Lee BK, Schnittger I. Diastolic dysfunction after mediastinal irradiation. American heart journal. 2005;150:977-982

215. Kruse JJ, Zurcher C, Strootman EG, Bart Cl, Schlagwein N, Leer JW, Wondergem J. Structural changes in the auricles of the rat heart after local ionizing irradiation. Radiotherapy and oncology : journal of the European Society for Therapeutic Radiology and Oncology. 2001;58:303-311

216. Franken NA, Camps JA, van Ravels FJ, van der Laarse A, Pauwels EK, Wondergem J. Comparison of in vivo cardiac function with ex vivo cardiac performance of the rat heart after thoracic irradiation. The British journal of radiology. 1997;70:1004-1009

217. Wondergem J, van der Laarse A, van Ravels FJ, van Wermeskerken AM, Verhoeve HR, de Graaf BW, Leer JW. In vitro assessment of cardiac performance after irradiation using an isolated working rat heart preparation. International journal of radiation biology. 1991;59:1053-1068

218. Lauk S, Trott KR. Radiation induced heart disease in hypertensive rats. International journal of radiation oncology, biology, physics. 1988;14:109-114

219. Boerma M, Wang J, Wondergem J, Joseph J, Qiu X, Kennedy RH, Hauer-Jensen M. Influence of mast cells on structural and functional manifestations of radiationinduced heart disease. Cancer research. 2005;65:3100-3107

220. Lara PC, Russell NS, Smolders IJ, Bartelink H, Begg AC, Coco-Martin JM. Radiationinduced differentiation of human skin fibroblasts: Relationship with cell survival and collagen production. International journal of radiation biology. 1996;70:683-692

221. Rodemann HP, Peterson HP, Schwenke K, von Wangenheim KH. Terminal differentiation of human fibroblasts is induced by radiation. Scanning microscopy. 1991;5:1135-1142; discussion 1142-1133

222. Russell NS, Lara PC, Grummels A, Hart AA, Coco-Martin JM, Bartelink H, Begg AC. In vitro differentiation characteristics of human skin fibroblasts: Correlations with radiotherapy-induced breast fibrosis in patients. International journal of radiation biology. 2000;76:231-240

223. Monceau V, Pasinetti N, Schupp C, Pouzoulet F, Opolon P, Vozenin MC. Modulation of the rho/rock pathway in heart and lung after thorax irradiation reveals targets to improve normal tissue toxicity. Current drug targets. 2010;11:1395-1404

224. Evans RA, Tian YC, Steadman R, Phillips AO. Tgf-beta1-mediated fibroblastmyofibroblast terminal differentiation-the role of smad proteins. Experimental cell research. 2003;282:90-100 
225. Burger A, Loffler H, Bamberg $M$, Rodemann HP. Molecular and cellular basis of radiation fibrosis. International journal of radiation biology. 1998;73:401-408

226. Hilbers FS, Boekel NB, van den Broek AJ, van Hien R, Cornelissen $S$, Aleman BM, van 't Veer $\mathrm{L}$, van Leeuwen FE, Schmidt MK. Genetic variants in tgfbeta-1 and pai-1 as possible risk factors for cardiovascular disease after radiotherapy for breast cancer. Radiotherapy and oncology : journal of the European Society for Therapeutic Radiology and Oncology. 2012;102:115-121

227. Kissinger CR, Parge HE, Knighton DR, Lewis CT, Pelletier LA, Tempczyk A, Kalish VJ, Tucker KD, Showalter RE, Moomaw EW, et al. Crystal structures of human calcineurin and the human fkbp12-fk506-calcineurin complex. Nature. 1995;378:641-644

228. Humar A, Michaels $M$, Monitoring AIWGolD. American society of transplantation recommendations for screening, monitoring and reporting of infectious complications in immunosuppression trials in recipients of organ transplantation. American journal of transplantation : official journal of the American Society of Transplantation and the American Society of Transplant Surgeons. 2006;6:262-274

229. Miller LW. Cardiovascular toxicities of immunosuppressive agents. American journal of transplantation : official journal of the American Society of Transplantation and the American Society of Transplant Surgeons. 2002;2:807-818

230. Matsumoto $T$, Saito E, Watanabe H, Fujioka T, Yamada T, Takahashi $Y$, Ueno T, Tochihara T, Kanmatsuse K. Influence of fk506 on experimental atherosclerosis in cholesterol-fed rabbits. Atherosclerosis. 1998;139:95-106

231. Roselaar SE, Schonfeld G, Daugherty A. Enhanced development of atherosclerosis in cholesterol-fed rabbits by suppression of cell-mediated immunity. The Journal of clinical investigation. 1995;96:1389-1394

232. Emeson EE, Shen ML. Accelerated atherosclerosis in hyperlipidemic c57bl/6 mice treated with cyclosporin a. The American journal of pathology. 1993;142:1906-1915

233. Donners MM, Bot I, De Windt LJ, van Berkel TJ, Daemen MJ, Biessen EA, Heeneman S. Low-dose fk506 blocks collar-induced atherosclerotic plaque development and stabilizes plaques in apoe-/- mice. American journal of transplantation : official journal of the American Society of Transplantation and the American Society of Transplant Surgeons. 2005;5:1204-1215

234. Drew AF, Tipping PG. Cyclosporine treatment reduces early atherosclerosis in the cholesterol-fed rabbit. Atherosclerosis. 1995;116:181-189

235. Kockx M, Jessup W, Kritharides L. Cyclosporin a and atherosclerosis--cellular pathways in atherogenesis. Pharmacology \& therapeutics. 2010;128:106-118

236. Kitamura M. Induction of the unfolded protein response by calcineurin inhibitors: A double-edged sword in renal transplantation. Nephrology, dialysis, transplantation : official publication of the European Dialysis and Transplant Association - European Renal Association. 2010;25:6-9

237. Naesens M, Kuypers DR, Sarwal M. Calcineurin inhibitor nephrotoxicity. Clinical journal of the American Society of Nephrology : CJASN. 2009;4:481-508

238. Berman $M$, Ben-Gal T, Stamler A, Kogan A, Shapira $Y$, Sagie A, Saute M, Kramer $M$, Aravot D, Vidne B, Sahar G. Lipid metabolism and immunosuppressive therapy in heart transplant recipients. Transplantation proceedings. 2003;35:677

239. Paul LC. Overview of side effects of immunosuppressive therapy. Transplantation proceedings. 2001;33:2089-2091

240. Olyaei AJ, de Mattos AM, Bennett WM. Nephrotoxicity of immunosuppressive drugs: New insight and preventive strategies. Current opinion in critical care. 2001;7:384-389

241. Ichimaru N, Takahara S, Kokado Y, Wang JD, Hatori M, Kameoka H, Inoue T, Okuyama A. Changes in lipid metabolism and effect of simvastatin in renal transplant recipients induced by cyclosporine or tacrolimus. Atherosclerosis. 2001;158:417-423 
242. Textor SC, Taler SJ, Canzanello VJ, Schwartz L, Augustine JE. Posttransplantation hypertension related to calcineurin inhibitors. Liver transplantation : official publication of the American Association for the Study of Liver Diseases and the International Liver Transplantation Society. 2000;6:521-530

243. Bechstein WO. Neurotoxicity of calcineurin inhibitors: Impact and clinical management. Transplant international : official journal of the European Society for Organ Transplantation. 2000;13:313-326

244. Hohage H, Arlt M, Bruckner D, Dietl KH, Zidek W, Spieker C. Effects of cyclosporin a and fk 506 on lipid metabolism and fibrinogen in kidney transplant recipients. Clinical transplantation. 1997;11:225-230

245. Sander M, Victor RG. Hypertension after cardiac transplantation: Pathophysiology and management. Current opinion in nephrology and hypertension. 1995;4:443-451

246. Scherrer U, Vissing SF, Morgan BJ, Rollins JA, Tindall RS, Ring S, Hanson P, Mohanty PK, Victor RG. Cyclosporine-induced sympathetic activation and hypertension after heart transplantation. The New England journal of medicine. 1990;323:693-699 




\section{chapter two}

\section{Low- but not high-dose FK506 treatment}

confers atheroprotection due to alternative macrophage activation and unaffected cholesterol levels

Karen Gabriels*, Lili Bai*, Erwin Wijnands, Mat Rousch, Mat J.A.P. Daemen, J.W. Cohen Tervaert, Erik A.L. Biessen, Sylvia Heeneman

*Authors contributed equally

Thrombosis and Haemostasis 2010;104(1):143-50 


\section{Abstract}

Previous studies showed both pro- and anti-atherogenic effects of immunosuppressant drug FK506 on atherosclerosis. As these divergent/ paradoxical results of FK506 may at least in part be attributable to differences in FK506 dosing, we have, in the current study, assessed dose-dependent effects of FK506 on atherosclerotic lesion formation as well as on inflammatory parameters relevant to atherosclerosis. Unlike low-dose FK506, high-dose FK506 did not protect against atherosclerosis in $\mathrm{ApoE}^{-/}$mice. The high dose induced hypercholesterolemia, whereas the low dose did not. Both low- and high-dose FK506 treatment significantly reduced systemic $\mathrm{CD}^{+}$and $\mathrm{CD} 4^{+} \mathrm{CD} 25^{+}$ $\mathrm{T}$-cell populations, and showed similar suppression of Foxp $3^{+}$regulatory T-cell populations. Increased IL- $4^{+} \mathrm{CD} 4^{+}$T-cells and decreased IgG-MDA-LDL antibody titers pointed to a selective, albeit modest $\mathrm{Th}_{2}$ skewing in the high-dose treatment group, despite the advanced stage of atherosclerosis. Low concentrations of FK506, however, skewed bone marrow-derived macrophage polarization towards a M2-macrophage phenotype, whereas the high concentration did not. A low-dose FK506 treatment regime protected against atherosclerosis by suppressing T-cell activation and favoring (M2) macrophage polarization. Although a high-dose FK506 treatment effected a similar T-cell suppressive effect, with an even more pronounced shift towards $\mathrm{Th}_{2}$-type immune responses, this did not translate in atheroprotection due to the hypercholesterolemia and absent M2 skewing. 


\section{Introduction}

A potent immunosuppressive drug, FK506 (tacrolimus) is widely used in patients following transplantation. At a molecular level, FK506 binds to the cytosolic FK506 binding protein (FKBP) 12-member of the FKBP family. ${ }^{1}$ In Tlymphocytes, FK506 interacts with FKBP12 to form a FK506-FKBP12 complex. ${ }^{2}$ This complex blocks calcineurin, a $\mathrm{Ca}^{2+}$-calmodulin-regulated protein phosphatase. As a consequence, calcineurin fails to dephosphorylate amongst others cytosolic nuclear factor of activated T-cells (NFAT), thereby inhibiting its translocation to the nucleus. NFAT is one of the most important transcriptional factors involved in the activation of cytokine genes such as interleukin (IL)-2. In addition, NFAT partners with the transcription factor AP-1 (Fos-Jun) in the nucleus of 'effector' T-cells. As a consequence, FK506 will inhibit both NFAT and NFAT-AP1 function in transactivating cytokine genes, genes that regulate T-cell proliferation and other genes that orchestrate an active immune response. ${ }^{3}$ Less is known about the role of calcineurin and NFAT in innate immune responses. Calcineurin inhibitors have been shown to induce a state of reduced responsiveness in dendritic cells and macrophages. ${ }^{4}$ Atherosclerosis is a chronic inflammatory disease in which NFAT responsive cytokines such as IL-2 are deemed to play a prominent role. In a previous study, we showed that FK506 at a low dose of $0.05 \mathrm{mg} / \mathrm{kg} /$ day beneficially affected the progression of murine atherosclerosis, reducing plaque area and increasing cell density and collagen content. ${ }^{5}$ Intriguingly and in contrast to our findings, Matsumoto et al. reported that FK506 treatment deteriorated atherosclerosis in cholesterol-fed rabbits. $^{6}$ In their study, a relatively high dose of FK506 was applied. Conceivably dose-specific effects of FK506 on cell subsets relevant to atherosclerosis ${ }^{7}$ may explain these paradoxical findings. For clinical practice, it is important to comprehend the mechanisms underlying these potentially dose-dependent effects of FK506 on atherosclerosis, in particular as in organ transplant recipients a high-dose regime was seen to be associated with substantial side-effects. ${ }^{8,9}$ Therefore, in this study, we investigated effects of low- and high-dose FK506 treatment on atherosclerosis and atherosclerosisrelated immunomodulation in apolipoprotein $\mathrm{E}(A D O E)^{-/-}$mice. 
As our data pointed to dose-dependent immunoregulatory effects of FK506, in vivo and in vitro experiments were designed to address this in more detail. Firstly, we studied whether in vivo low-/high-dose FK506 treatment differentially affected T-cell patterns and activity in spleen, lymph node and peripheral blood. Secondly, as a further measure of the effects of FK506 on Thelper (Th) cell skewing, splenic gene expression of T-cell transcription factors such as Foxp3, T-bet, RoryT and GATA-3 were analyzed by real-time polymerase chain reaction (PCR). Finally, the effect of ex vivo and in vitro treatment of low-/high-dose FK506 on cytokine secretion by T-cells and macrophage polarization were investigated.

\section{Materials and methods}

\section{In vivo studies}

\section{Mouse model of collar-induced atherosclerosis}

Animal experiments were approved by the regulatory authority of the University of Maastricht and were performed in compliance with the Dutch government guidelines. Male $A p o E^{/-}$mice (14 weeks old, C57BL/6J background) were fed a Western-type diet throughout the experiment. Carotid atherosclerotic lesions were induced by silastic tubing (collar) around the carotid artery, as described by von der Thüsen et al. ${ }^{10}$. To assess the effect of FK506 on lesion initiation, one week after collar-placement, osmotic minipumps (Alzet type 2004, Alzet, Cupertino, CA, USA) containing FK506 (Fujisawa $\mathrm{GmbH}$, München, Germany) were placed subcutaneously to achieve a pumping rate of either $0.05 \mathrm{mg} / \mathrm{kg} /$ day or $1 \mathrm{mg} / \mathrm{kg} /$ day. Mice without treatment served as controls. Mice were sacrificed four weeks after pump placement.

\section{Assessment of serum cholesterol levels and anti-ox-LDL antibody levels}

Serum cholesterol levels were determined with the CHOD-PAP method (Roche Diagnostics, Burgess Hill, UK). Anti-oxidized low-density lipoprotein (oxLDL) antibody levels were determined by ELISA as described previously ${ }^{11}$. In brief, serum IgM and IgG isotypes of oxLDL antibodies were determined by coating 
MaxiSorp 96-well plates (Nunc, Roskilde, Denmark) overnight with $100 \mu \mathrm{g}$ native LDL or malondialdehyde- (MDA) oxLDL. Mouse plasma was added in duplicate at a 1:20 dilution for IgG antibody levels and a 1:50 dilution for IgM antibody overnight at $4^{\circ} \mathrm{C}$. Plates were then incubated with either alkaline phosphatase-labeled anti-mouse IgG or IgM (1:4000, Jackson ImmunoResearch Laboratory, West Grove, PA, USA). Plates were read at $405 \mathrm{~nm}$ in an ELISA reader. Anti-oxLDL antibody levels were calculated by subtracting the mean absorbance of native LDL from that of oxLDL.

\section{Tissue harvesting and analysis}

Cross-sections from the right common carotid artery after in situ perfusionfixation were processed for morphometric analysis as described previously ${ }^{12}$. (Immuno)histochemical stainings were performed to detect macrophages (anti-MAC3 antibody), collagen (picrosirius red) and $\mathrm{CD3}^{+}$T-cells (anti-CD3 antibody) as described previously ${ }^{12}$.

\section{Fluorescence-activated cell sorting (FACS)-analysis}

To assess systemic $\mathrm{CD}^{+}, \mathrm{CD}^{+}, \mathrm{CD}^{+} \mathrm{CD}^{2} 5^{+}$and $\mathrm{CD} 8^{+}$cell numbers, spleen and lymph node cells were isolated and single-cell suspensions were made. Erythrocytes in peripheral blood and spleen were removed by hypotonic lysis with $\mathrm{NH}_{4} \mathrm{Cl}$. Cells were incubated first with anti-CD16/32 (eBioscience, San Diego, CA, USA) to block Fc binding and subsequently incubated with anti-CD3FITC, anti-CD8-Pacific blue, anti-CD25-APC (eBioscience) and anti-CD4-PerCp (BD- Pharmingen, San Diego, CA, USA). Foxp3-positive cells were detected with $\mathrm{PE}$ anti-mouse/rat Foxp3 Staining Set, according to the manufacturer's instructions (eBioscience). Cells were analyzed using FACS Canto II (BD) flow cytometer.

As a measure of $T h_{1} / T h_{2}$ skewing, expression of intracellular cytokine levels in splenic T-cells was assessed. Hereto, splenocytes from mice treated in vivo for four weeks with low- and high-dose of FK506, were stimulated for 2 hours (h) with $50 \mathrm{ng} / \mathrm{ml}$ PMA (Sigma, St Louis, MO, USA) and $1 \mu \mathrm{g} / \mathrm{ml}$ ionomycin (Sigma). Cell suspensions were then incubated with $1 \mu \mathrm{l} / \mathrm{ml}$ of Golgistop (1:1000 dilution, BD- Pharmingen) for $4 \mathrm{~h}$. Cells were washed and incubated with anti-CD16/32 (eBioscience) to block Fc binding. After fixation and permeabilisation, intracellular cytokines were stained with anti-IL-4-PE 
(BD) and anti-interferon(IFN)- $\gamma$-PECy7 (BD). The IFN- - - and IL-4-producing CD4 ${ }^{+}$ T-cells were analyzed with FACS Canto II (BD) flow cytometer.

\section{Quantitative PCR (qPCR)}

RNA was extracted from the spleen lysate with Nucleospin RNA II kit (MACHEREY-NAGEL, Düren, Germany). CDNA was generated with iSCript $^{\mathrm{TM}}$ cDNA synthesis kit (BIO-RAD, Hercules, CA). Real-time PCR was performed with a Taqman IQ ${ }^{\text {TM }}$ SYBR Green Super Mix (BIO-RAD). Primer sequences for Foxp3, T-bet, RorpT, GATA3, cyclophilin and $18 \mathrm{~S}$ are shown in Supplemental Table I on page 61. Gene expression was normalized to the average expression of cyclophilin and $18 \mathrm{~S}$.

\section{Ex vivo and in vitro studies}

\section{Effect of FK506 treatment on CD4 ${ }^{+}$T-cells}

Mice were treated using identical protocols as described above. $\mathrm{CD}^{+}{ }^{+}$T-cells were isolated from splenocytes of FK506-treated or untreated mice using the Negative Isolation Kit (Dynal, Biotech ASA, Oslo, Norway). The purity of CD4 ${ }^{+} \mathrm{T}-$ cells was $87 \pm 5 \%$ as evaluated by FACS (data not shown).

$\mathrm{CD}^{+}$T-cells were incubated with PMA $(4 \mathrm{ng} / \mathrm{ml})$ and ionomycin $(500 \mathrm{nM})$ for $48 \mathrm{~h}$. IL-4, IL-10 and IFN- $\gamma$ in supernatants were assayed by ELISA according to the manufacturer's instructions (BD).

Effects of FK506 on Jurkat T-cells - cytokine secretion profiles and NFAT/IKB luciferase reporter assays

Jurkat T-cells were pretreated with FK506 at a dose of 0, 20, and $2000 \mathrm{ng} / \mathrm{ml}$ for $1 \mathrm{~h}$. Cells were then stimulated with PMA $(8 \mathrm{ng} / \mathrm{ml})$ and ionomycin (1000 $\mathrm{nM}$ ) for $48 \mathrm{~h}$. IFN $-\gamma$ and IL-10 in supernatant were assayed by ELISA according to the manufacturer's instructions (Sanquin, Amsterdam, The Netherlands).

Jurkat T-cells were transfected with $1.8 \mu \mathrm{g}$ plkB-luciferase reporter plasmid (kindly provided by Dr. M. de Winther, Maastricht University, The Netherlands) or $1.8 \mu \mathrm{g}$ pNFAT-luciferase reporter plasmid (kindly provided by Dr. L. de Windt, Maastricht University, The Netherlands) using Amaxa reagent V. After $24 \mathrm{~h}$, cells were pretreated with 0, 20 and $2000 \mathrm{ng} / \mathrm{ml}$ FK506 in 
medium for $2 \mathrm{~h}$ followed by stimulation with $25 \mathrm{ng} / \mathrm{ml}$ PMA and $1 \mu \mathrm{M}$ ionomycin for $18 \mathrm{~h}$. Cells were lysed and luciferase-activity was measured with a luminometer.

\section{Effect of FK506 treatment on bone marrow-derived macrophages (BMDM)}

BMDM were isolated from the femur and tibia of $A p o E^{/-}$mice. Cells were cultured in standard RPMI culture medium containing L-glutamine, HEPES, 10\% fetal calf serum, $100 \mathrm{lU} / \mathrm{ml}$ penicillin/streptomycin, and 15\% L929 cell conditioned medium. Macrophage polarization was induced by culturing BMDM for $16 \mathrm{~h}$ at a density of $1 \times 10^{6}$ cells $/ \mathrm{ml}$ in the aforementioned medium supplemented with $10 \mathrm{ng} / \mathrm{ml}$ lipopolysaccharides (LPS) to induce M1 polarization or $20 \mathrm{ng} / \mathrm{ml} \mathrm{IL-4}$ to induce $\mathrm{M} 2$ polarization in the presence of FK506 at a concentration of 0,20 and $2000 \mathrm{ng} / \mathrm{ml}$. After $16 \mathrm{~h}$, cells were harvested, RNA was isolated and cDNA was generated using iSCript ${ }^{\mathrm{TM}}$ CDNA synthesis kit (BIO-RAD). Real-time PCR was performed with a Taqman $I^{T M}$ SYBR Green Super Mix (BIO-RAD). Primer sequences for specific M1 markers (nitric oxide synthase 2 (Nos2), IL-18), and M2 markers (Arginase-1, mannose receptor (MR) and IL-10) are shown in Supplemental Table I on page 61. Gene expression was normalized to the expression of cyclophilin.

\section{Statistical analysis}

All results were expressed as mean \pm standard error of the mean (SEM). Differences between values were considered significant at $p \leq 0.05$ using MannWhitney U test.

\section{Results}

Low-dose FK506 inhibits collar-induced atherosclerosis whereas high-dose did not

Mice weight was not affected by low-/high-dose FK506 treatment (data not shown). Concentrations of FK506 in blood were essentially similar as described in our previous study ${ }^{5}$. Total serum cholesterol level was significantly elevated in mice that received high-dose FK506 in vivo treatment compared to control and low-dose treatment group. In contrast, low-dose FK506 in vivo treatment 
did not significantly alter serum cholesterol level compared to controls (Figure 1A).

FK506 treatment did not affect kidney morphology. Focal microaneurysm was present in glomeruli at similar frequency in the low-/highdose group. There was no histological evidence of tubular toxicity. Acute (indicated by isometric vacuolization and thrombotic mesangiopathy) or chronic kidney toxicity (indicated by arteriolar hyalinosis and tubularinterstitial fibrosis atrophy) were not observed.

In keeping with our earlier study ${ }^{5}$, plaque size in low-dose FK506-treated mice was significantly lower $(72.1 \%, p=0.05)$ compared to controls (Figure 1B). Remarkably, plaque sizes of control and high-dose-treated mice were essentially similar (Figure 1B). Representative micrographs of HE-stained crosssections are shown in Figure 1D-F. There was no significant difference in macrophage content between the control, low- and high-dose group (Supplemental Figure IA on page 62). Lipid/necrotic core content in the lowdose group tended to be decreased compared with control group ( $p=0.075)$, an effect that was not observed after high-dose treatment (Figure 1C). In addition, both low- and high-dose treatment did not affect collagen content (Supplemental Figure IB on page 62). Furthermore, FK506 treatment did not affect the lesion $\mathrm{CD}^{+}$leukocyte content (Supplemental Figure IC on page 62). In the adventitia, however, high- but not low-dose FK506 reduced the number of infiltrating $\mathrm{CD}^{+}$leukocytes (Supplemental Figure ID on page 62). However, despite the apparent reduction in inflammatory status of the plaque after high-dose FK506 treatment, this did translate in an altered atherogenic response as plaque size was comparable to that of the control group. 

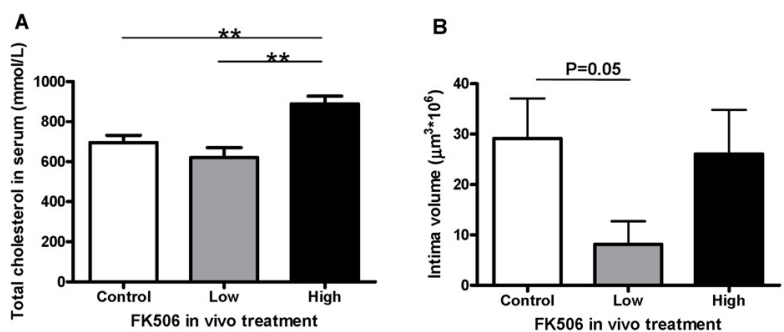

C
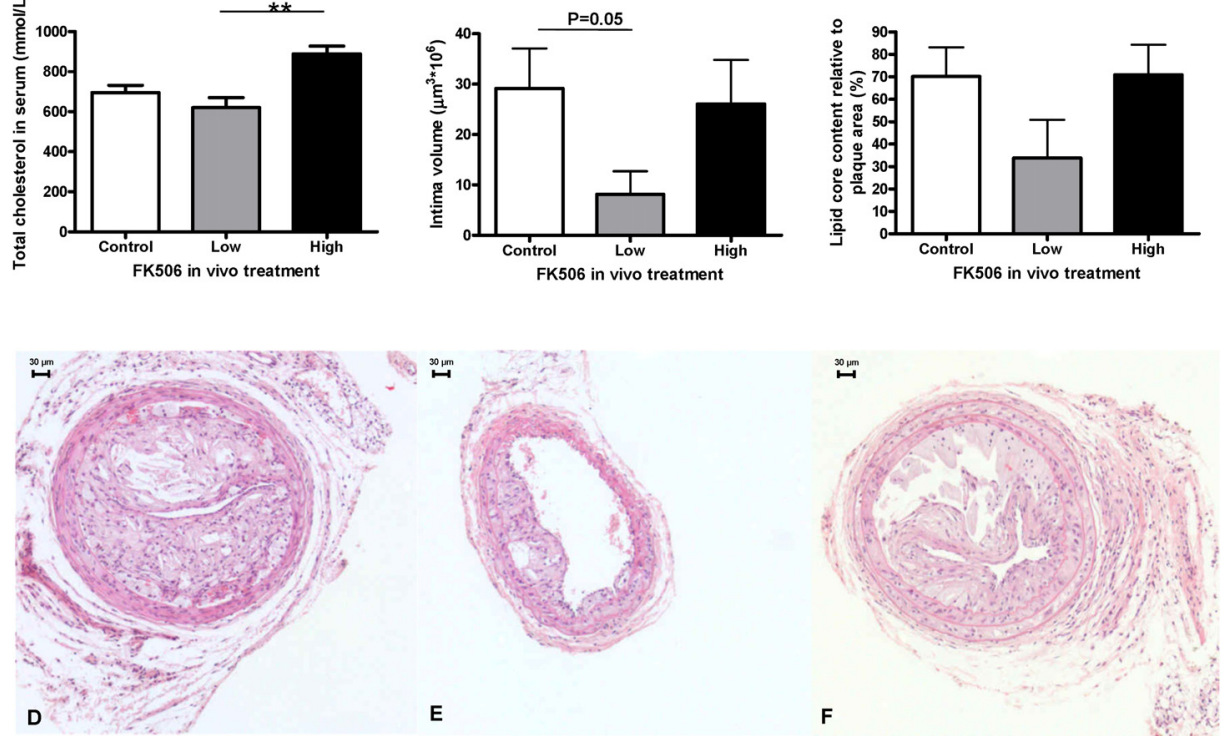

Figure 1. Effect of low- $(0.05 \mathrm{mg} / \mathrm{kg} /$ day) and high-dose $(1 \mathrm{mg} / \mathrm{kg} /$ day $)$ FK506 in vivo on serum cholesterol level (A, $n=5-6$ per group), intima volume (B), and lipid/necrotic core content (C), and representative $\mathrm{HE}$-stained cross-sections of control $(\mathbf{D}, \mathrm{n}=10)$, low-dose $(\mathrm{E}, \mathrm{n}=9)$ and highdose $(\mathbf{F}, \mathrm{n}=10)$ FK506-treated mice, respectively. ${ }^{* *} \mathrm{p}<0.01$. 
Both low- and high-dose FK506 treatment suppressed peripheral immune activity

To examine whether FK506 influenced lesion development indirectly by altering peripheral immune activity, single-cell suspensions of spleen, lymph nodes and blood were analyzed to determine the number of T-cells by FACS (Figure 2). The $\mathrm{CD}^{+}$T-cell \% out of total living cells in spleen, lymph node and blood was significantly reduced after low- and high-dose FK506 treatment (Figure $2 \mathrm{~A}$ ). The relative abundance of $\mathrm{CD} 4^{+}$cells within the $\mathrm{CD}^{+}$population in lymph node was significantly reduced after high-dose FK506 treatment, whereas low dose did not alter the $\mathrm{CD}^{+}$cell content (Figure 2B). Overall, highbut not low-dose FK506 decreased the lymph node $\mathrm{CD} 4^{+}$to $\mathrm{CD}^{+}$ratio (Figure 2D). Activated T-cell numbers $\left(\mathrm{CD} 4^{+} \mathrm{CD} 25^{+}\right)$in spleen, lymph node and blood were reduced to a similar extent with low- and high-dose treatment as compared to controls (Figure 2E). Finally, low- and high-dose treatment resulted in a comparable, albeit moderate suppression of spleen Foxp ${ }^{+}$ regulatory $\mathrm{T}$-cell population (Figure $\mathbf{2 F}$ ).
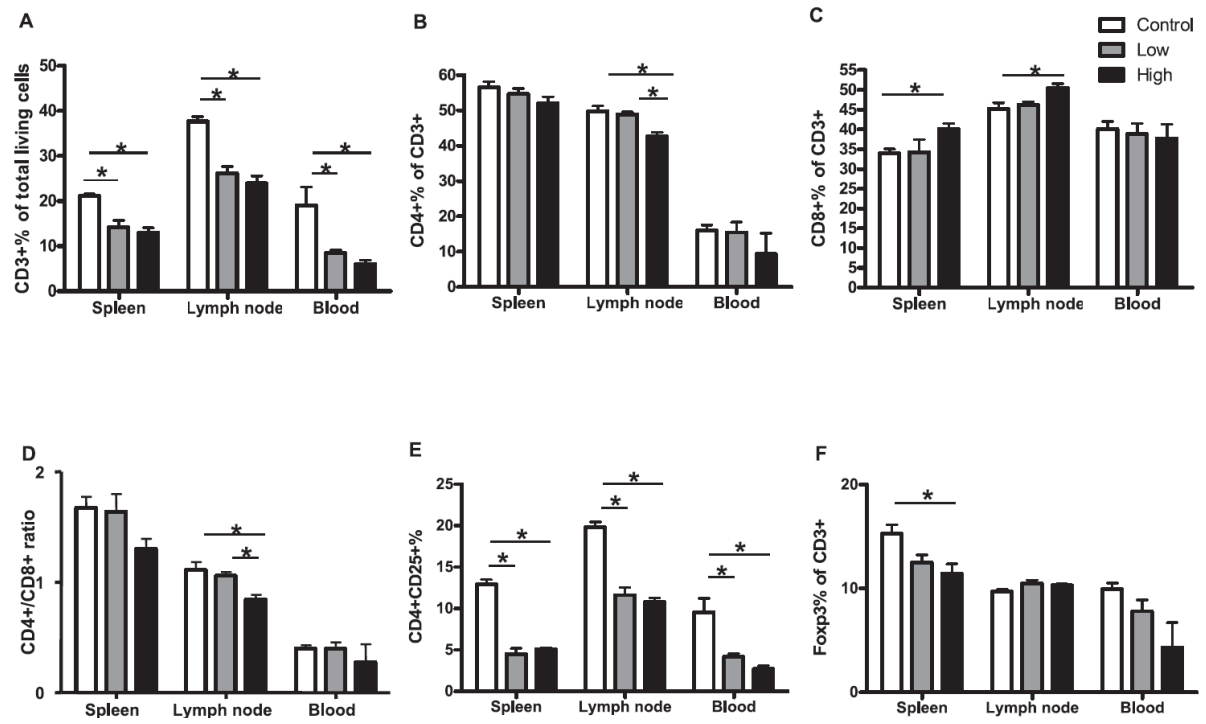

Figure 2. Flow-cytometric analysis of the effect of low- $(0.05 \mathrm{mg} / \mathrm{kg} / \mathrm{day})$ and high-dose (1 $\mathrm{mg} / \mathrm{kg} /$ day) FK506-treatment ( $\mathrm{n}=6$ per group) on $\% \mathrm{CD}^{+}$T-cells of total living cells $(\mathbf{A}), \% \mathrm{CD}^{+}$of $\mathrm{CD}^{+}{ }^{+}$-cells (B), \% $\mathrm{CD}^{+}$of $\mathrm{CD}^{+}{ }^{+}$-cells (C), $\mathrm{CD} 4^{+}$to $\mathrm{CD}^{+}$ratio (D), $\mathrm{CD} 4^{+} \mathrm{CD} 25^{+}$T-cells of total cells (E), \% Foxp3 ${ }^{+}$of $\mathrm{CD}^{+}$T-cells (F). ${ }^{*} \mathrm{p}<0.05$. 
To further investigate the effects of FK506 treatment on critical T-cell differentiation factors, gene-expression of Foxp3, T-bet, RorpT and GATA-3 in spleens of in vivo treated animals was analyzed (Supplemental Figure II on page 62). Foxp3 and RoryT gene expression was not affected by FK506 treatment, whereas both the low- and high-dose led to a profound decrease in T-bet and GATA-3 expression, compatible with the observed systemic reduction of $\mathrm{CD}^{+}$and $\mathrm{CD} 4^{+} \mathrm{CD} 25^{+}$T-cell populations. Thus, both low- and highdose FK506 treatment led to a systemic suppression of T-cell numbers and activation.

\section{High-dose FK506 treatment decreased IgG antibodies to MDA-oxLDL}

As the aforementioned reduction in CD4/CD8 ratio might reflect a shift in humoral immune response, we investigated whether FK506 treatment affected anti-oxLDL antibody titers, anti-MDA-LDL IgG and IgM titers in serum. As shown in Figure 3, low- and high-dose FK506 did not affect anti-MDA-LDL IgM levels. Anti-MDA-IgG levels, however, were sharply decreased in the highdose group only.

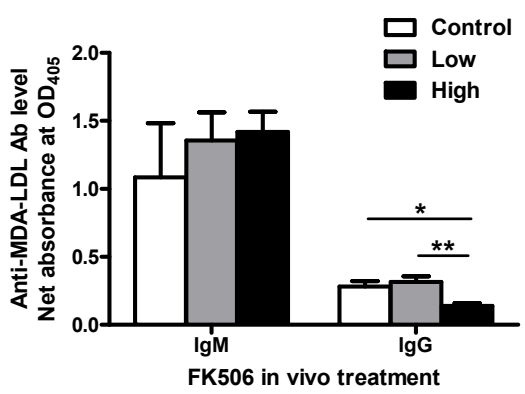

Figure 3. Analysis of the antibody titers (IgM and $\operatorname{IgG}$ ) to oxLDL in $A p o E^{/-}$mice treated in vivo for four weeks with low- $(0.05 \mathrm{mg} / \mathrm{kg} /$ day) and high-dose $(1 \mathrm{mg} / \mathrm{kg} /$ day) FK506. The net absorbance was calculated by subtracting the mean absorbance of native LDL from that of MDA-oxLDL. $n=5-6$ mice per group, ${ }^{*} p<0.05,{ }^{* *} p<0.01$. 


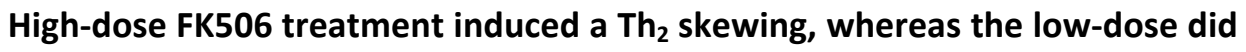
not affect $\mathrm{Th}_{1}-\mathrm{Th}_{2}$ parameters

Giving the important role of calcineurin-signaling in T-cell responses, the effect of FK506 treatment on T-cell function and cytokine secretion profiles was further investigated in in vivo and in vitro experiments.

Assessment of the percentage of IL-4-positive T-cells by FACS showed that in vivo low-dose FK506 treatment did not affect Th-cell skewing to $\mathrm{Th}_{2}$ (IL4) or $\mathrm{Th}_{1}$ (IFN- $\gamma$ ) (Figure 4); high-dose treatment did not alter intracellular IFN$\mathrm{V}^{+} \mathrm{CD} 4^{+}$cell numbers but did increase IL- $4^{+} \mathrm{CD} 4^{+}$cell numbers, suggestive of a $\mathrm{Th}_{2}$ skewing.

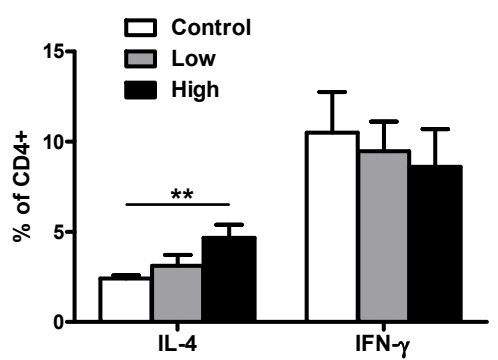

Figure 4. Presence of IL-4 $4^{+}$and IFN- $\gamma^{+} \mathrm{CD}^{+}$splenocytes in $A p o E^{-/}$mice treated in vivo for four weeks with low- $(0.05 \mathrm{mg} / \mathrm{kg} /$ day) and high-dose ( $1 \mathrm{mg} / \mathrm{kg} /$ day) FK506. $\mathrm{n}=5-6$ mice per group, $* * p<0.01$.

Cytokine secretion patterns of isolated $\mathrm{CD} 4^{+}$cells from in vivo treated animals were analyzed to further assess the potential effects of FK506 on $\mathrm{Th}_{1^{-}}$ $\mathrm{Th}_{2}$ skewing. As shown in Supplemental Figure IIIA-C on page 63, neither lownor high-dose in vivo FK506 treatment affected secretion of $\mathrm{Th}_{2}$ cytokines (IL-4 and IL-10) or the $\mathrm{Th}_{1}$ cytokine IFN- $\gamma$.

In the next experiment, Jurkat T-cells were used to verify the lack of effect of FK506 in CD4 ${ }^{+}$T-cells. IL-10 and IFN- $\gamma$ secretion were significantly suppressed by both 20 and 2000 ng/ml FK506 (Supplemental Figure IIID-E on page 63), suggesting that the human Jurkat T-cells are more responsive to FK506, regardless of the dose. The effect of FK506 on transcriptional activation of downstream calcineurin-responsive transcription factors was addressed in a luciferase-reporter assay. NFAT activity was almost completely inhibited independent of the FK506 concentration, confirming the observed strong inhibition of IFN- $\gamma$ and IL-10 secretion by FK506 in Jurkat T-cells. IKB activity, on 
the other hand was unaffected by FK506, even at concentrations of 2000 $\mathrm{ng} / \mathrm{ml}$, suggesting that FK506 does not interfere with nuclear factor KB (NFKB) signaling in Jurkat cells (data not shown). These data are in close agreement with our earlier study ${ }^{5}$, in which FK506 inhibited the activity of NFAT but not NFKB in RAW264.7 macrophages and vascular smooth muscle cells (vSMCs).

\section{Low-dose FK506 induced M2 macrophage skewing in vitro}

As the data on analysis of T-cell function did not reveal major dose-dependent differences in FK506 response, we focused on effects on function and phenotype of BMDM. Baseline expression of M2 macrophage markers such as arginase-1, IL-10 and MR, and M1 macrophage markers such as IL-18 and Nos2 were measured in $\mathrm{BMDM}$ isolated from $\mathrm{ApoE}^{-/}$mice, treated in vitro with low$(20 \mathrm{ng} / \mathrm{ml})$ and high-concentration $(2000 \mathrm{ng} / \mathrm{ml}) \mathrm{FK} 506$. Compared to control and low-FK506 concentration, high-FK506 concentration significantly reduced gene expression of M2 macrophage markers arginase-1 and IL-10 (Figure 5A). In keeping, the high concentration of FK506 almost ablated M2 macrophage MR expression as compared to the low concentration (Figure 5A). The low concentration, on the other hand, significantly elevated $M 2$ macrophage marker MR (Figure 5A). Both low- and high-FK506 concentrations did not significantly alter M1 macrophage marker (Nos2 and IL-18) expression (Figure 5A). Therefore, low-FK506 concentration skewed basal macrophage polarization towards an M2 macrophage phenotype, whereas high-FK506 concentration reversed this effect. In addition, the capacity of BMDM to polarize in response to IL-4 (M2) or LPS (M1) stimuli in vitro was investigated. Again, the low-concentration FK506 significantly suppressed M1 macrophage marker IL-18 (Figure 5B) and enhanced that of the M2 marker arginase-1 (Figure 5C), indicating a pronounced M2 macrophage skewing upon low-FK506 concentration. The high concentration, however, downregulated both M1 (IL18; Figure 5B) and M2 (MR; Figure 5C) macrophage marker expression in LPSand IL-4-primed macrophages respectively. 

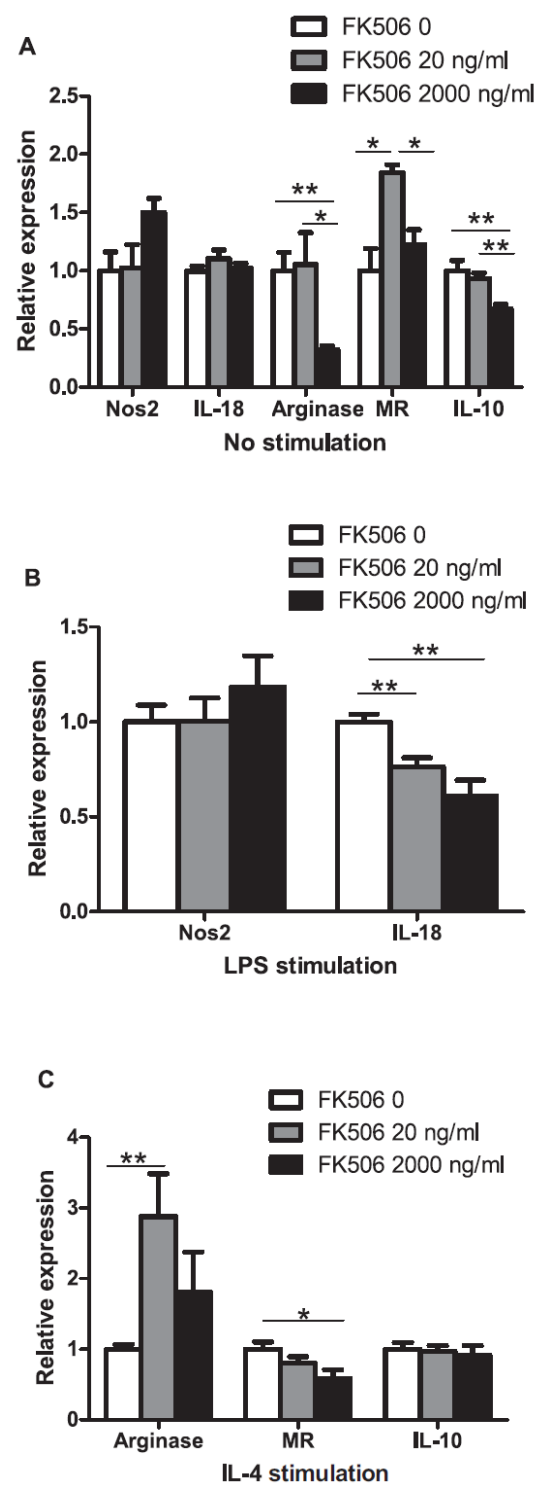

Figure 5: Effect of FK506 in vitro treatment on M1 (Nos2, IL-18) and M2 (arginase-1, mannose receptor (MR) and IL-10) macrophage marker expression of non-stimulated (A), LPS-stimulated (B) and IL-4-stimulated (C) BMDM. BMDM from $A p o E^{-/}$mice were isolated and cultured in the absence or presence of LPS/IL-4 for $16 \mathrm{~h}$ and FK506 at a concentration of 0,20 and $2000 \mathrm{ng} / \mathrm{ml}$. BMDM cell lysates were analyzed for $\mathrm{M} 1$ and $\mathrm{M} 2$ marker gene expression relative to cyclophilin expression. $\mathrm{n}=6$ per group, ${ }^{*} \mathrm{p}<0.05,{ }^{*} \mathrm{p}<0.01$. 


\section{Discussion}

Inflammation plays an important role in atherosclerosis formation, rendering immunosuppressive therapy an attractive therapeutic modality in the treatment of this disease. Though the immunosuppressive drug FK506 is widely used in clinical transplantation, diverse side-effects of this drug in clinical dosage limit its utility in other applications such as the promising treatment of (auto)immune diseases and atherosclerosis. ${ }^{13}$ We have in this study investigated the dose-dependent effect of FK506 on collar-induced carotid atherogenesis in $A p o E^{--}$mice. This is an extension of our previous study $^{5}$ in which only the low-dose regime was applied in the treatment of atherosclerosis. Consistent with our previous study, low dose of FK506 markedly reduced atherosclerosis. High-dose treatment on the other hand did not protect against atherosclerosis at all. Plaque macrophage and collagen content were not influenced by FK506 treatment regardless of the dose. $\mathrm{CD} 3^{+}$leukocyte content in the adventitia was, however, markedly inhibited by the high-dose treatment. FK506 increased total serum cholesterol levels, resulting in significantly increased cholesterol levels in the high-dose group only. FACS analysis showed that both low- and high-dose FK506 treatment significantly reduced systemic $\mathrm{CD}^{+}$and $\mathrm{CD} 4^{+} \mathrm{CD} 25^{+}$T-cell populations. Assessment of Thcell differentiation (based on intracellular cytokine expression) and anti IgG MDA-LDL antibody titers pointed to a selective, albeit modest $\mathrm{Th}_{2}$ skewing in the high-dose treatment group only, despite the fact that atherosclerosis was more pronounced in the high-dose treatment group.

As the data on analysis of T-cell function did not reveal major dosedependent differences in FK506 response, we focused on effects on macrophage function, as calcineurin-signaling pathways are also important in innate immune responses. ${ }^{4}$ Low-dose FK506 skewed basal as well as LPSprimed polarization of BMDM towards a M2-macrophage phenotype, whereas high dose did not. These data suggest that the low-dose FK506 treatment regime protected against atherosclerosis partly due to a favorable (M2) macrophage polarization, whereas this protective effect did not occur at the high dose. In addition, the increase in cholesterol levels may have conduced to a lack of effect of high-dose FK506 treatment, despite a compensatory switch towards a $\mathrm{Th}_{2}$ response that was observed in the high-dose group only. 
The use of calcineurin inhibitors, such as FK506 and cyclosporine A (CsA), in transplant recipients has been associated with the development of hypercholesterolemia. ${ }^{14,} 15$ In our study, the high-dose FK506 treatment induced a (mild) hypercholesterolemia whereas the low dose did not. From a clinical point of view, this would make the low dose amendable to long-term treatment of chronic inflammatory disorders such as atherosclerosis. Besides FK506, other immunosuppressive drugs, for instance mycophenolate mofetil (MMF), sirolimus, CSA and their concomitant anti-inflammatory effects have been studied in atherosclerotic animal models. ${ }^{16} \mathrm{MMF}$ and sirolimus showed a consistent atheroprotective potential. Regarding CSA and FK506, results in animal studies are rather contradictory, probably due to specific animal models used and large differences in dosages. ${ }^{16}$ As shown, the dosage could very well be of vital importance as many of the side-effects of FK506 and CsA reported in patients occur at high dose and long-term regimes. Indeed our animal study indicated that only low dose suppressed atherosclerosis, whereas high dose did not.

Given the recent data on the interaction between NFAT and regulatory T-cell activity ${ }^{17}$, we investigated whether NFAT can act as regulator of the $\mathrm{Th}_{1} / \mathrm{Th}_{2}$ balance. NFAT proteins are expressed in most cells of the immune system and play a pivotal role in the transcriptional activation of cytokine genes and other genes critical for the immune response. In the current study, several independent sets of experiments showed that both the low- and highdose FK506 led to a repression of systemic T-cell numbers and activation. This was mirrored by a suppression of the expression of important T-cell transcription factors T-bet and GATA-3. It is thought that the fate of CD4 ${ }^{+}$Thcell differentiation is at least in part governed by T-bet $\left(\mathrm{Th}_{1}\right)$, GATA-3 $\left(\mathrm{Th}_{2}\right)$ and Rory $T\left(T_{17}\right)$, respectively. ${ }^{18}$ Low- and high-dose FK506 had comparable suppressive effects on T-bet and GATA3, while leaving RorpT expression unaltered. Although low- and high-dose FK506 treatment did not affect in vitro secretion of $\mathrm{Th}_{2}$ cytokines, such as IL-4 and IL-10, or the $\mathrm{Th}_{1}$ cytokine IFN- $\gamma$ in isolated $\mathrm{CD}^{+}$cells from in vivo treated mice, FK506 markedly reduced IFN- $\gamma$ and IL-10 release by human Jurkat T-cells. This reduction, however, was equally potent after both low- and high-concentration FK506. While the in vitro studies did not point to dose-dependent effects of FK506 on $\mathrm{Th}_{1}-\mathrm{Th}_{2}$ differentiation, spleen cells showed a modest enrichment in IL- $4^{+} \mathrm{Th}_{2}$ cells after 
high-dose FK506. In addition, high- but not the low-dose treatment reduced the $C D 4 / C D 8$ ratio, suggestive of a decreased humoral immune response. ${ }^{19}$ In support of this finding, anti-MDA-IgG titers were decreased in the high-dose group only. It has been suggested that IgM anti-oxLDL antibodies may have a protective role, whereas IgG anti-oxLDL displays a more pathogenic role in atherosclerosis. ${ }^{11,} 20$ Taken together, high-dose FK506 induced hypercholesterolemia and a selective, albeit modest $\mathrm{Th}_{2}$ skewing, concomitant with decreased humoral response. A similar $\mathrm{Th}_{2}$ response during hypercholesterolemia has been described in a study by Zhou et al. ${ }^{21}$, where $A p o E^{\prime-}$ mice on a high-fat diet also showed modulation of the T-cell response towards $\mathrm{Th}_{2}$.

Low-dose treatment of FK506 appeared to induce a subtle shift towards an atheroprotective immune response, especially in the myeloid lineage. Although the role of calcineurin in T-cell function is well established, less is known on its role in innate immune cells. Jennings et al. ${ }^{4}$ recently showed that FK506 treatment of macrophages and dendritic cells induced a state of reduced LPS responsiveness in vitro and conferred protection to LPS toxicity in vivo in mice. This tolerance to LPS may well be associated with a M2macrophage phenotype, as Sly et al. ${ }^{22}$ recently reviewed that $S H I P^{-/}$mice did not display LPS-induced tolerance, most likely due to a M2-macrophage skewing. In the present study, a low-, but not a high-concentration FK506 induced a M2 polarization, which is generally considered anti-inflammatory and anti-atherogenic. ${ }^{23}$ Indeed, Khallou-Laschet et al. ${ }^{24}$ recently showed that lesion development in $A p o E^{/-}$mice was associated with a progressive M2 to M1 switch of plaque macrophages. Conceivably, the detainment of the M2 phenotype by low-dose FK506 might have at least partly contributed to the pronounced atheroprotective effects seen in this study.

In summary, low- and high-dose FK506 differently affected atherogenesis. Our findings indicate that a low-dose FK506 treatment regime protects against atherosclerosis by suppressing T-cell activation and favoring (M2) macrophage polarization. While high-dose FK506 treatment effected a similar T-cell suppressive effect, with an even more pronounced shift towards $\mathrm{Th}_{2}$-type immune responses, this did not translate in atheroprotection due to the hypercholesterolemia and absent M2 skewing. The fact that low- but not high-dose FK506 treatment reduced plaque development and induced M2 
macrophage polarization suggests that it can be particularly effective for longterm therapy of chronic inflammatory disorders such as atherosclerosis. 


\section{Supplemental data}

Supplemental Table I. Primer sequences.

Forward primer ( $\left.5^{\prime}-3^{\prime}\right)$

Reverse primer (5'-3')

\begin{tabular}{ccc}
\hline FoxP3 & CCAGTCTGGAATGGGTGTCC & CTGCTTGGCAGTGCTTGAGA \\
T-bet & GGGAACCGCTTATATGTCCA & GGGCTGGTACTTGTGGAGAG \\
GATA3 & CAGCTGCCAGATAGCATGAA & GCAGGCATTGCAAAGGTAGT \\
RoryT & CGACTGGAGGACCTTCTACG & TTGGCAAACTCCACCACATA \\
Arginase & ATGGAAGAGACCTTCAGCTAC & GCTGTCTTCCCAAGAGTTGGG \\
MR & GCAAATGGAGCCGTCTGTGC & CTCGTGGATCTCCGTGACAC \\
IL-10 & TCTTACTGACTGGCATGAGGATCA & GTCCGCAGCTCTAGGAGCAT \\
Nos2 & CAGCTGGGCTGTACAAACCTT & CATTGCAAGTGAAGCGTTTCG \\
IL-18 & ACAACTTTGGCCGACTTCAC & GGGTTCACTGGCACTTTGAT \\
IFN-y & TGGCTGTTTCTGGCTGTTACTG & GCTCTGCAGGATTTTCATGTCA \\
cyclophilin & CAAATGCTGGACCAAACACAA & TTCACCTTCCCAAAGACCACAT \\
\hline
\end{tabular}



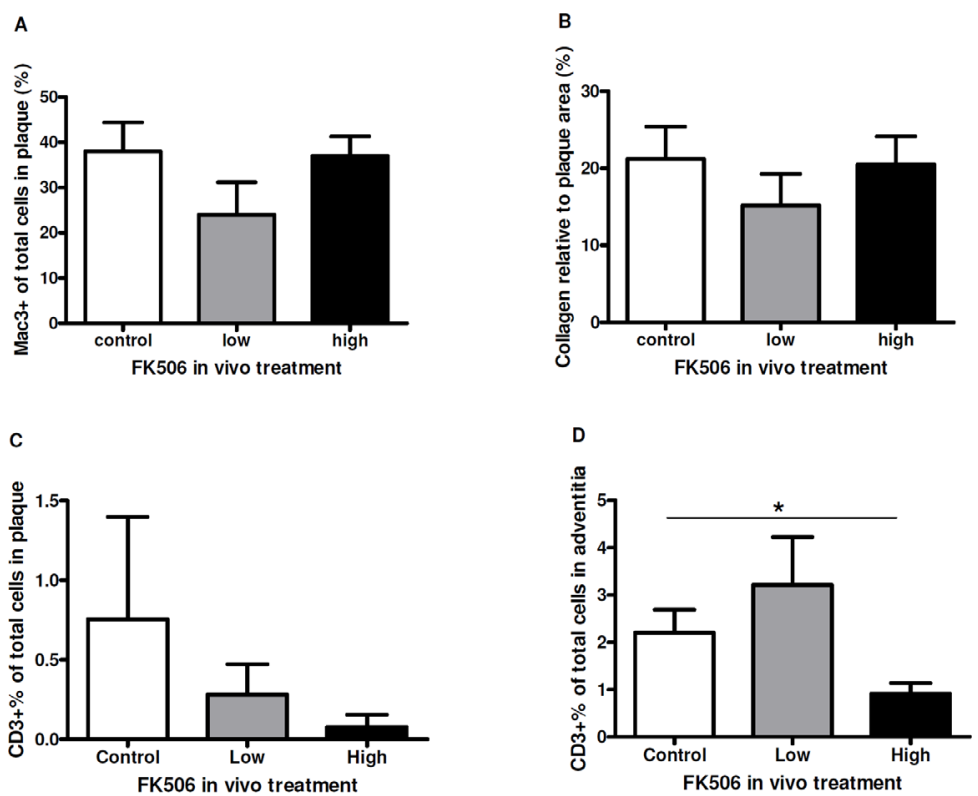

Supplemental Figure I. The effect of low- $(0.05 \mathrm{mg} / \mathrm{kg} / \mathrm{day})$ and high-dose $(1 \mathrm{mg} / \mathrm{kg} /$ day) FK506 treatment on macrophage- (A), collagen- (B) and $\mathrm{CD}^{+}$leukocyte- (C and D) content. Macrophage content was expressed as MAC3-positive cell numbers relative to total number of plaque cells (A). Collagen content is expressed as area stained by picrosirius red relative to the plaque area (B). T-cell content was expressed as CD3-positive cell numbers relative to total number of plaque cells (C) or adventitial cells (D). $n=8-10$ mice per group, ${ }^{*} p<0.05$.

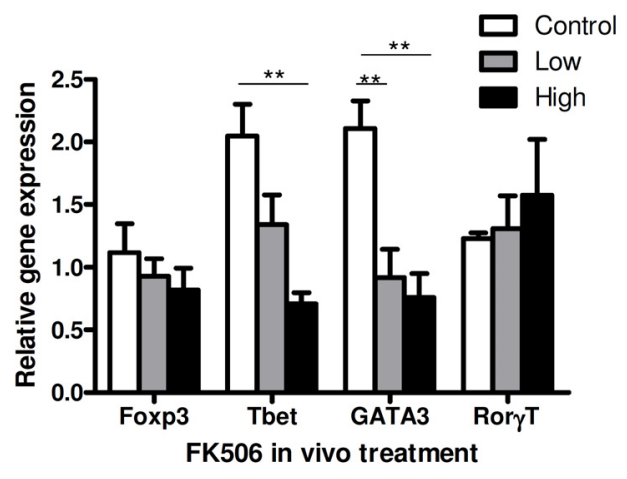

Supplemental Figure II. qPCR of Foxp3, Tbet, GATA3 and RoryT mRNA expression relative to the average expression of $18 \mathrm{~S}$ and cyclophilin in spleen of $A p o E^{--}$mice treated in vivo for 4 weeks with low- $(0.05 \mathrm{mg} / \mathrm{kg} /$ day) and high-dose (1 mg/kg/day) of FK506. $\mathrm{n}=5-10$ mice per group, $* * p<0.01$. 


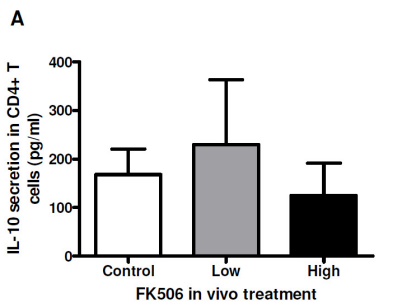

B

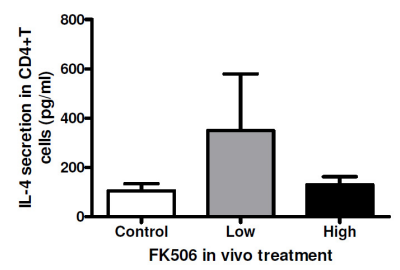

$\mathrm{E}$
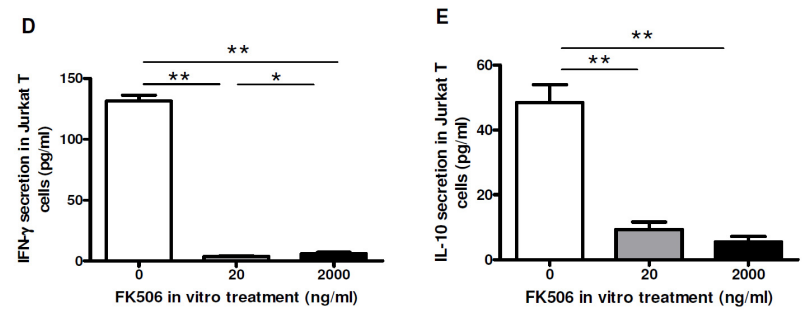

C

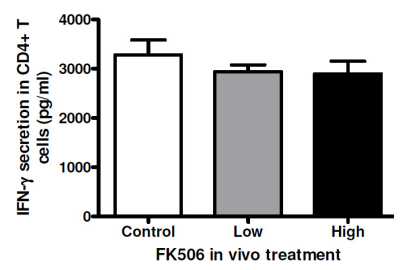

Supplemental Figure III. Effects of FK506 treatment on cytokine secretion. Panel A-C show IL-10 (A), IL-4 (B) and IFN- $\gamma$ (C) secretion by spleen $\mathrm{CD}^{+}{ }^{+}$T-cells isolated from $A p o E^{-/}$mice treated with low- $(0.05 \mathrm{mg} / \mathrm{kg} / \mathrm{day})$ and high-dose ( $1 \mathrm{mg} / \mathrm{kg} /$ day) of FK506 ( $\mathrm{n}=4$ mice per group). Panel $\mathbf{D}$ and E show the effect of FK506 in vitro treatment on IFN- $\gamma$ (D) and IL-10 (E) secreted by PMA- and ionomycin-stimulated Jurkat T-cells that were pretreated with FK506 of 0, 20, and $2000 \mathrm{ng} / \mathrm{ml}$ for 1 hour ( $n=6$ per group). $* p<0.05, * * p<0.01$. 


\section{References}

1. Sewell TJ, Lam E, Martin MM, Leszyk J, Weidner J, Calaycay J, Griffin P, Williams H, Hung S, Cryan J, et al. Inhibition of calcineurin by a novel FK-506-binding protein. J Biol Chem. 1994;269:21094-21102.

2. Abraham RT, Wiederrecht GJ. Immunopharmacology of rapamycin. Annu Rev Immunol. 1996;14:483-510.

3. Rao A, Luo C, Hogan PG. Transcription factors of the NFAT family: regulation and function. Annu Rev Immunol. 1997;15:707-747.

4. Jennings C, Kusler B, Jones PP. Calcineurin inactivation leads to decreased responsiveness to LPS in macrophages and dendritic cells and protects against LPSinduced toxicity in vivo. Innate Immun. 2009;15:109-120.

5. Donners MM, Bot I, De Windt LJ, van Berkel TJ, Daemen MJ, Biessen EA, Heeneman S. Low-dose FK506 blocks collar-induced atherosclerotic plaque development and stabilizes plaques in ApoE-/- mice. Am J Transplant. 2005;5:1204-1215.

6. Matsumoto $T$, Saito E, Watanabe H, Fujioka T, Yamada T, Takahashi Y, Ueno T, Tochihara T, Kanmatsuse K. Influence of FK506 on experimental atherosclerosis in cholesterol-fed rabbits. Atherosclerosis. 1998;139:95-106.

7. Wakabayashi H, Karasawa Y, Tanaka S, Kokudo Y, Maeba T. The effect of FK506 on warm ischemia and reperfusion injury in the rat liver. Surg Today. 1994;24:994-1002.

8. Jain AB, Fung JJ, Todo S, Alessiani M, Takaya S, Abu-Elmagd K, Tzakis A, Starzl TE. Incidence and treatment of rejection episodes in primary orthotopic liver transplantation under FK 506. Transplant Proc. 1991;23:928-930.

9. Shapiro R, Jordan M, Fung J, McCauley J, Johnston J, Iwaki Y, Tzakis A, Hakala T, Todo S, Starzl TE. Kidney transplantation under FK 506 immunosuppression. Transplant Proc. 1991;23:920-923.

10. von der Thusen JH, van Berkel TJ, Biessen EA. Induction of rapid atherogenesis by perivascular carotid collar placement in apolipoprotein E-deficient and low-density lipoprotein receptor-deficient mice. Circulation. 2001;103:1164-1170.

11. Smook ML, van Leeuwen M, Heeringa P, Damoiseaux JG, Theunissen R, Daemen MJ, Lutgens E, Cohen Tervaert JW. Anti-oxLDL antibody isotype levels, as potential markers for progressive atherosclerosis in APOE and APOECD40L mice. Clin Exp Immunol. 2008;154:264-269.

12. Bot I, von der Thusen JH, Donners MM, Lucas A, Fekkes ML, de Jager SC, Kuiper J, Daemen MJ, van Berkel TJ, Heeneman S, Biessen EA. Serine protease inhibitor Serp-1 strongly impairs atherosclerotic lesion formation and induces a stable plaque phenotype in ApoE-/-mice. Circ Res. 2003;93:464-471.

13. Muraoka K, Fujimoto K, Sun X, Yoshioka K, Shimizu K, Yagi M, Bose H, Jr., Miyazaki I, Yamamoto K. Immunosuppressant FK506 induces interleukin-6 production through the activation of transcription factor nuclear factor (NF)-kappa(B). Implications for FK506 nephropathy. J Clin Invest. 1996;97:2433-2439.

14. Berman $M$, Ben-Gal T, Stamler A, Kogan A, Shapira $Y$, Sagie A, Saute M, Kramer M, Aravot D, Vidne B, Sahar G. Lipid metabolism and immunosuppressive therapy in heart transplant recipients. Transplant Proc. 2003;35:677.

15. Ichimaru N, Takahara S, Kokado Y, Wang JD, Hatori M, Kameoka H, Inoue T, Okuyama A. Changes in lipid metabolism and effect of simvastatin in renal transplant recipients induced by cyclosporine or tacrolimus. Atherosclerosis. 2001;158:417-423.

16. Heeneman S, Donners MM, Bai L, Daemen MJ. Drug-induced immunomodulation to affect the development and progression of atherosclerosis: a new opportunity? Expert Rev Cardiovasc Ther. 2007;5:345-364. 
17. Wu Y, Borde M, Heissmeyer V, Feuerer M, Lapan AD, Stroud JC, Bates DL, Guo L, Han A, Ziegler SF, Mathis D, Benoist C, Chen L, Rao A. FOXP3 controls regulatory $T$ cell function through cooperation with NFAT. Cell. 2006;126:375-387.

18. Miller SA, Weinmann AS. Common themes emerge in the transcriptional control of T helper and developmental cell fate decisions regulated by the T-box, GATA and ROR families. Immunology. 2009;126:306-315.

19. Maue AC, Haynes L. CD4+ T cells and immunosenescence--a mini-review. Gerontology. 2009;55:491-495.

20. Shoenfeld $Y, W u$ R, Dearing LD, Matsuura E. Are anti-oxidized low-density lipoprotein antibodies pathogenic or protective? Circulation. 2004;110:2552-2558.

21. Zhou X, Paulsson G, Stemme S, Hansson GK. Hypercholesterolemia is associated with a T helper (Th) 1/Th2 switch of the autoimmune response in atherosclerotic apo Eknockout mice. J Clin Invest. 1998;101:1717-1725.

22. Sly LM, Ho V, Antignano F, Ruschmann J, Hamilton M, Lam V, Rauh MJ, Krystal G. The role of SHIP in macrophages. Front Biosci. 2007;12:2836-2848.

23. Mantovani A, Garlanda C, Locati M. Macrophage diversity and polarization in atherosclerosis: a question of balance. Arterioscler Thromb Vasc Biol. 2009;29:14191423.

24. Khallou-Laschet J, Varthaman A, Fornasa G, Compain C, Gaston AT, Clement M, Dussiot M, Levillain O, Graff-Dubois S, Nicoletti A, Caligiuri G. Macrophage plasticity in experimental atherosclerosis. PLoS One;5:e8852. 



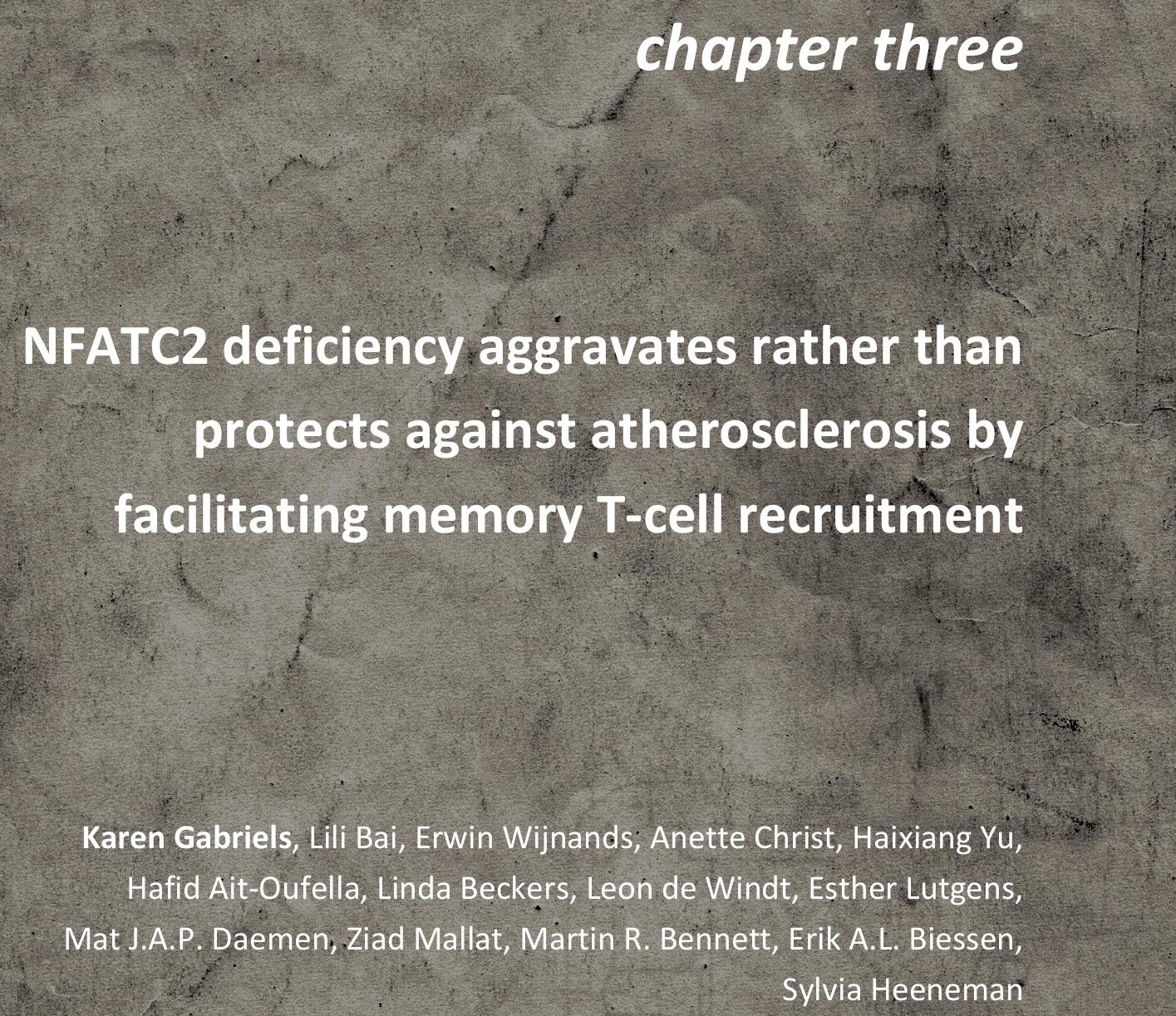

Sylvia Heeneman

Submitted for publication 


\section{Abstract}

Objective Nuclear Factor of Activated T-cells C2 (NFATC2) is a crucial transcriptional regulator of numerous inflammatory genes during immune responses. The recently reported role of NFATC2 in regulatory T-cell function and Thelper $_{1}$-cell differentiation, as well as the finding that the NFAT signaling inhibitor FK506 diminished atherosclerosis, suggestive of a pro-atherogenic role of NFATC2, led us to investigate the effect of NFATC2 deficiency on atherosclerosis.

Approach and Results The effect of NFATC2 deficiency on atherosclerosis and T-cell phenotype and function was investigated in $L D L r^{-/}$mice with either whole body or hematopoietic NFATC2 deficiency. Contrary to our expectations, both murine models showed significantly increased advanced atherosclerotic lesion burden in the aortic arch, and sharply increased plaque $\mathrm{CD}^{+} \mathrm{T}$-cell content. NFATC2-deficient splenic T-cells displayed $\mathrm{Th}_{2}$-biased T-cell responses in vivo, enhanced $\mathrm{CD} 3$ expression and $\mathrm{CD} 3$-induced mitogenic response, which was not attributable to a change in regulatory T-cell function. Importantly, flow-cytometric analysis of T-cell subsets revealed a clear shift from naïve towards migratory $\mathrm{CD} 44^{\text {high }} \mathrm{CD}_{2} \mathrm{~L}^{\text {low }}$ effector/memory T-cells in NFATC2 ${ }^{-/}$ $/ / L D L r^{-/}$as well as hematopoietic NFATC2-deficient $L D L r^{-/}$mice. Moreover, NFATC2 ${ }^{-1-}$ T-cells showed impaired spleen grafting and preferential homing to the atherosclerotic plaque.

Conclusions Collectively, NFATC2 knockout and hematopoietic depletion resulted in an augmented rather than compromised T-cell response, which underlies the aggravated atherogenic response. 


\section{Introduction}

The transcription factor Nuclear Factor of Activated T-cells (NFAT) is essential for an adequate immune response. ${ }^{1,2}$ It is expressed in a variety of immune cells such as T- and B-lymphocytes, natural killer cells, monocytes and other myeloid cells. $^{2-4}$ The NFAT family encompasses five well-characterized members with NFATC1 and NFATC2 as major isoforms relevant to T-cell activation. ${ }^{5,6}$ NFAT function is tightly regulated by calcineurin, a calmodulindependent calcium-activated phosphatase. ${ }^{7}$ Upon dephosphorylation NFAT translocates to the nucleus to induce the expression of several cytokine genes, such as interleukins IL-2, IL-3, IL-4, IL-5, interferon- $\gamma$ (IFN- - ), tumor necrosis factor $\alpha$ (TNF $\alpha$ ), granulocyte macrophage colony-stimulating factor (GM-CSF), and TNF family members, such as CD4OL, CTLA-4, and FasL (reviewed in ref. ${ }^{8}$ ). However, NFAT-family members $\mathrm{C} 1$ and $\mathrm{C} 2$ were also reported to regulate $\mathrm{T}$ helper (Th) and regulatory T-cell (Treg) differentiation ${ }^{1,9-11}$, and mice deficient in NFATC2 showed modest splenomegaly with hyperproliferation of T- and Blymphocytes and an augmented allergic phenotype characterized by eosinophilia in vivo and in vitro. ${ }^{12-15}$ Despite the pleiotropic activity of NFAT, intervention in NFAT signaling by immunosuppressive drugs such as FK506 (tacrolimus) and cyclosporine A (CsA) is widely regarded as an effective therapeutic strategy in a number of chronic inflammatory and autoimmune disorders as well as in transplant rejection. ${ }^{16-19}$

Several lines of evidence indicate that NFAT is implicated in chronic inflammatory processes that underlie atherosclerosis. Firstly, low-dose treatment with FK506 inhibited the initiation and progression of collar-induced atherosclerosis in apolipoprotein $E(A p O E)^{-1-}$ mice. ${ }^{20,}{ }^{21}$ Secondly, NFATC2 was recently reported to control Treg development and suppressive function ${ }^{11,22,23}$ and NFATC2 deficiency led to $\mathrm{Th}_{2}$-biased T-cell responses ${ }^{9}, 12,24,25$, both processes that were previously shown to attenuate atherosclerosis. ${ }^{26}$ However, no data are available on the role of NFATC2 in atherosclerosis. Here, we showed that NFATC2 knockout and hematopoietic depletion led to $\mathrm{Th}_{2}$ skewed immune responses and, contrary to our expectations, deteriorated atherosclerosis. NFATC2-deficient T-cells showed an enhanced mitogenic response to $\mathrm{CD} 3$ stimulation and displayed an effector/memory T-cell 
phenotype more prone to migrate to the atherosclerotic plaque, which may have contributed to the exacerbation of atherosclerosis.

\section{Materials and methods}

\section{Animal experimental design}

Female low density lipoprotein receptor-knockout $\left(L D L r^{-/}\right)$mice on a $C 57 \mathrm{BL} / 6 \mathrm{~J}$ background (6-8 weeks old) were obtained from Jackson (Bar Harbor, USA). The generation of NFATC2 ${ }^{-/}$mice has been described previously. ${ }^{13}$ NFATC2 and LDLr double-knockout (DKO) mice were generated by intercrossing $L D L r^{-/}$mice three times with NFATC2 ${ }^{-/}$mice on a C57BL/6J background. Age- and gendermatched $14 \mathrm{LDLr}^{-/}$and $15 \mathrm{NFATC2} \% / / L D L r^{-/}$mice were placed on a highcholesterol diet containing $0.25 \%$ cholesterol (Special Diets Services, Witham, Essex, UK) for 8 weeks.

In addition to NFATC2 ${ }^{-/} / / L_{L L r^{-/}}$mice, NFATC2 ${ }^{-/}$-bone-marrow transplanted (BMT) mice were generated. One day before the BMT, $L D L r^{-1}$ recipient mice were exposed to a single dose of 9 Gray (Gy) of total body irradiation (Roentgen source, Philips MU15F/225). Bone marrow was harvested by flushing femurs and tibias of either $L D L r^{-/}$or $N F A T C 2^{-/}$donor mice with phosphate-buffered saline (PBS). Single-cell suspensions were prepared by passing the cells through a 19-gauge needle, followed by a 25 gauge-needle. Age- and gender-matched 9 irradiated $L D L r^{-/}$-recipient mice received $5 \times 10^{6}$ $L D L r^{-/}$-bone-marrow cells each and 10 irradiated $L D L r^{-/}$-recipients received $5 \mathrm{x}$ $10^{6}$ NFATC2 $^{-1}$-bone-marrow cells by intravenous injection into the tail vein. BMT-recipient mice were housed in sterilized filter-top cages and fed a sterilized normal-chow diet and sterile drinking water containing neomycin $(100 \mathrm{mg} / \mathrm{L})$ and polymyxin B $(60.000 \mathrm{U} / \mathrm{L})$. Four weeks after the BMT, antibiotic treatment was discontinued and the diet was switched to a high-cholesterol diet containing $0.25 \%$ cholesterol (Special Diets Services, Witham, Essex, UK) for another 23 weeks to induce atherosclerosis.

All animal experiments were approved by the regulatory authority of the University of Maastricht and were performed in compliance with the Dutch government guidelines. 


\section{Determination of chimerism}

Chimerism in transplanted mice was determined as described previously. ${ }^{27}$ Genomic DNA was isolated from the blood of recipient $L D L r^{-/}$mice, at 27 weeks after the BMT, using the Illustra blood genomic prep Mini spin kit (GE Healthcare, Amersham, England). The standard curve was composed of DNA from $\mathrm{LDLr}^{-1-}$ and $\mathrm{LDLr}^{\mathrm{WT}}$ blood mixed at different ratios. Chimerism was determined by quantifying the amount of LDL $^{W T}$ DNA in samples from $40 \mu \mathrm{l}$ peripheral blood by quantitative real-time PCR (qPCR). Samples were assayed in duplicate using the Taqman IQ ${ }^{\mathrm{TM}}$ SYBR Green Super Mix (BIO-RAD, Hercules, CA). Chimerism was calculated as the percentage of LDLr ${ }^{\mathrm{WT}}$ DNA in the blood samples. An average of $96.8 \%$ of the white blood cells was of donor origin, establishing successful engraftment. The degree of chimerism was identical in NFATC2 $^{-1}$ - and $L D L r^{-/}$-BMT mice $(97.1 \% \pm 0.3$ vs $96.5 \% \pm 0.5)$.

\section{Plasma cholesterol}

Serum cholesterol levels of NFATC2 ${ }^{-/} / / L_{L L r^{-1}}, N F A T C 2^{-/}$-chimeric and control mice were determined with the CHOD-PAP method (Roche Diagnostics).

\section{Histological analysis of atherosclerosis}

To study the development of atherosclerosis, sections of the aortic arch were prepared and analyzed as described previously. ${ }^{28}$ Briefly, the arterial system was perfused with PBS containing $0.1 \mathrm{mg} / \mathrm{ml}$ nitroprusside (Sigma, St Louis, $\mathrm{MO})$. The aortic arch, including its main branch points, was excised and fixed with $1 \%$ paraformaldehyde. Approximately 40 serial cross-sections ( $4 \mu \mathrm{m}$ thick) from the longitudinally embedded aortic arch were cut. Every fifth paraffin section was stained with hematoxylin and eosin (H\&E) for the analysis of plaque number and area. Plaque area was measured on 4 of these sections per aortic arch, selected to cover the central part of each lesion. Lesions containing only foam cells were categorized as initial, whereas advanced lesions were determined by the presence of necrotic core and/or fibrous cap. The relative collagen content in atherosclerotic lesions that was stained positive for Sirius red was determined under a microscope coupled to a computerized morphometry system (Quantimet 570, Leica Qwin V3, Leica, Rijswijk, The Netherlands). Morphometric analysis was performed by one blinded investigator (K.G., intra-observer variability was $<10 \%$ ). 


\section{Immunohistochemical stainings}

Sections were stained with the following antibodies: Rabbit anti-mouse/human CD3 (1:200, Dako, Glostrup, Denmark) to detect T-cells, MAC3 rat monoclonal antibody (1:30, BD Biosciences Pharmingen, San Diego, CA) to detect macrophages, CD45 (1:5000, BD Biosciences Pharmingen, San Diego, CA) to detect leukocytes, and cleaved caspase-3 (1:100, Cell Signaling, Boston, MA) to detect apoptotic cells. To determine the relative amounts of T-cells, macrophages, leukocytes and caspase-3-positive cells, the number of respectively CD3-, MAC3-, CD45- and cleaved caspase-3-positive cells in the lesions were divided by the corresponding lesion area. All measurements were conducted by one investigator (K.G., intra-observer variability was $<10 \%$ ).

\section{Fluorescence-activated cell sorting (FACS)}

Spleens, blood and lymph nodes were isolated and single-cell suspensions were created (spleens and lymph nodes were pushed through a $70 \mu \mathrm{m}$ strainer) for FACS analysis using BD FACS CANTO II. All samples were collected in PBS and stored on ice during staining and analysis. Erythrocytes in peripheral blood and spleen were removed by hypotonic lysis with $\mathrm{NH}_{4} \mathrm{Cl}$. First, cells were incubated with anti-CD16/32 (eBioscience, San Diego, CA) in FACS buffer $(0.5 \%$ bovine serum albumin (BSA) and 1mM EDTA in PBS) for 30 minutes to block Fcreceptor binding and secondly stained with anti-CD3, anti-CD8, anti-CD4, antiCD25 (eBioscience, San Diego, CA) and anti-CD45R/B220 (BD-Biosciences Pharmingen, San Diego, CA). Leukocytes were furthermore incubated with anti-CD62L (eBioscience, San Diego, CA) and anti-CD44 (BD-Biosciences Pharmingen, San Diego, CA) to identify naïve T-cells (defined as $\mathrm{CD} 44^{\text {low }}{ }^{\mathrm{CD}} 62 \mathrm{~L}^{\text {high }}$ ) and effector/memory T-cells (defined as CD44 ${ }^{\text {high }} \mathrm{CD} 62 \mathrm{~L}^{\text {low }}$ ). Cells were fixed and made permeable, according to the manufacturer's instructions (eBioscience, San Diego, CA), for anti-Foxp3, anti-Tbet, antiGATA3, anti-RoryT, anti-IFN- $\gamma$, (eBioscience, San Diego, CA), anti-IL-4 (BDBiosciences Pharmingen, San Diego, CA) and anti-IL-17 (Becton \& Dickinson, Franklin Lakes, US) intracellular stainings.

Flow cytometric analysis of IFN- $\gamma, \mathrm{IL}-4$ and IL-17 was performed after 5 hours in vitro incubation (Golgistop $(1 \mu \mathrm{l} / \mathrm{ml}, \mathrm{BD} 554724)$ was added after 1 hour incubation) with phorbol 12-myristate 13-acetate (PMA, 50ng/ml, Sigma p1585, St Louis, MO) and ionomycin (1 $\mu \mathrm{g} / \mathrm{ml}$, Sigma 10634, St Louis, MO) of 
splenocytes resuspended in medium (RPMI medium supplemented with 25 mM HEPES buffer, 2 mM L-glutamine, 1\% penicillin/streptomycin (Gibco) and $10 \%$ fetal calf serum (FCS)). Splenocytes were seeded in 24 -well plates at a density of $1 \times 10^{6}$ cells $/ \mathrm{ml}$.

\section{Preparation of lysates and western immunoblotting}

T-cells were sorted from the spleen of NFATC2 ${ }^{--} / / L D L r^{-/}$and $L D L r^{-/}$mice, and lysed in $1 \mathrm{x}$ protein loading buffer. Lysates were subsequently boiled for 5 minutes and separated by electrophoresis (SDS-PAGE). Proteins were transferred to polyvinylidene fluoride (PVDF) membranes and incubated for $1 \mathrm{~h}$ at room temperature with blocking solution $(5 \%(\mathrm{w} / \mathrm{v})$ milk $+0.1 \%$ Tween 20 in PBS (PBST)). To detect NFAT dephosphorylation, the membranes were first incubated for $1 \mathrm{~h}$ with anti-NFAT1 (NFATC2) antibody (1:000, NEBlab), antiNFAT2 (NFATC1) antibody (1:1000, Abcam) and anti-NFATC3 antibody (1:1000, Santa Cruz) in $5 \%(\mathrm{w} / \mathrm{v})$ milk/PBST, followed by $1 \mathrm{~h}$ incubation with secondary donkey anti-rabbit and sheep-anti mouse horse radish peroxidase- (HRP) conjugated (1:2000, GE Health) in 5\% (w/v) milk/PBST. Next, membranes were extensively washed in PBST and PBS and proteins were visualized by ECL-plus detection system according to the manufacturer's instructions (GE Life Sciences).

\section{T-cell proliferation and regulatory T-cell function assay}

Cell-proliferation experiment and Treg function assay were performed as described before. ${ }^{29}$ Cells were purified and pooled from 3 mice per group at the time of sacrifice. $\mathrm{CD} 4^{+} \mathrm{CD} 25^{-}$cells $\left(0.5 \times 10^{5}\right.$ cells) were cultured alone or in co-culture with $\mathrm{CD} 4^{+} \mathrm{CD} 25^{+}$cells at diverse concentrations $\left(0.5 \times 10^{5}, 0.25 \times 10^{5}\right.$, $\left.0.12 \times 10^{5}, 0.06 \times 10^{5}\right)$, in flat-bottomed 96-well microplates (total volume 200 $\mu \mathrm{l} /$ well). Cells were stimulated with purified soluble CD3-specific antibody (1 $\mu \mathrm{g} / \mathrm{ml}$, Pharmingen) in the presence of antigen-presenting cells $\left(0.1 \times 10^{5}\right.$ cells $)$ purified on CD11c-coated magnetic beads (Miltenyi Biotech). Cells were cultured at $37^{\circ} \mathrm{C}$ for 72 hours, pulsed with $1 \mu \mathrm{Ci}$ of $\left[{ }^{3} \mathrm{H}\right]$ thymidine (Amersham) and incubated for another 18 hours. Thymidine incorporation was assessed using a TopCount NXT scintillation counter (Perkin Elmer). 


\section{RNA isolation and real-time PCR}

RNA was extracted from spleen lysates with Nucleospin RNA II kit (MACHEREYNAGEL, Duren, Germany). cDNA was generated using isCript ${ }^{\mathrm{TM}}$ CDNA synthesis kit (BIO-RAD, Hercules, CA). qPCR was done with a Taqman IQ ${ }^{\text {TM }}$ SYBR Green Super Mix (BIO-RAD, Hercules, CA). Primer sequences of Tbet, IFN- - , GATA3, IL4, Foxp3, Cblb, Egr2, $18 \mathrm{~S}$ and cyclophilin are shown in Supplemental Table I on page 88. An average expression of $18 \mathrm{~S}$ and cyclophilin was considered as reference value for total RNA expression.

\section{In vivo trafficking experiments}

Wild-type (WT) and NFATC2 ${ }^{--}$mice received an intravenous injection of $90 \mu \mathrm{g}$ of lipopolysaccharides (LPS). Two hours after LPS injection, splenocytes from WT and NFATC2 ${ }^{-/}$mice were isolated and labeled with $2 \mu \mathrm{M}$ CFSE (Invitrogen) in PBS at $37^{\circ} \mathrm{C}$ for 15 minutes. Labeled cells were incubated in RPMI medium at $37^{\circ} \mathrm{C}$ for 30 minutes to ensure that by-products had passively diffused into the medium. After washing with PBS containing $0.1 \% \mathrm{BSA}, 3 \times 10^{7}$ of labeled cells in $0.2 \mathrm{ml}$ of PBS were injected intravenously into $A p o E^{-/}$-recipient mice (37-40 weeks old, 4 received labeled splenocytes from WT mice and 5 received labeled splenocytes from NFATC2 $\%$ mice). Forty two hours after the injection, mice were sacrificed and perfused with PBS. Spleen and aortic arch were harvested to identify the number of CFSE-positive cells that migrated to the spleen and atherosclerotic lesions. The percentage of CFSE-labeled splenocytes in the spleen was determined by FACS.

Perfused aortic arches were placed in Tissue-Tek O.C.T. embedding medium (Miles Inc), snap-frozen at $-160^{\circ} \mathrm{C}$ in liquid nitrogen-cooled isopentane (Baxter Scientific). Twenty cross-sections ( $4 \mu \mathrm{m}$ thick) from the longitudinally embedded fresh-frozen aortic arches were cut. Four sections with a distance of $20 \mu \mathrm{m}$ each were selected to analyze CFSE ${ }^{+}$cells in the lesions. Nuclei were counterstained using Mounting Medium with DAPI (VECTOR). Overlay images were acquired using fluorescence microscopy (Leica DM 5000B) with the filter system 13 to detect $\mathrm{CFSE}^{+}$cells, and SGR to detect DAPI. Lesional $\mathrm{CFSE}^{+}$-cell content was calculated from the total number of $\mathrm{CSFE}^{+}$cells divided by that of all cells in the lesion. Analysis was performed by one blinded investigator (L.B., intra-observer variability was $<10 \%$ ). 


\section{Statistics}

Statistical analyses were performed using a nonparametric Mann-Whitney $U$ test. The number of $\mathrm{CFSE}^{+}$cells in the lesion in the in vivo homing experiment was compared with independent sample $T$ test. Data are expressed as mean \pm SEM. Probability values of $<0.05$ were considered significant.

\section{Results}

\section{Serum cholesterol levels}

Western-type diet feeding for 8 weeks led, as expected, to increased plasma total cholesterol levels in $L D L r^{-/}$and NFATC2 $2^{-/} / / L D L r^{-/}$mice; however, cholesterol levels did not differ between $L D L r^{-/-}$and NFATC $2^{-/} / / L D L r^{-/-}$mice both at the start of the experiment and at sacrifice (Supplemental Figure I on page 88). Likewise, plasma cholesterol levels were comparable in $\mathrm{LDLr}^{-/}$mice transplanted with $L D L r^{-/-}$and $N F A T C 2^{-/-}$-bone marrow at sacrifice (Supplemental Figure I on page 88).

Increased atherosclerotic plaque area and T-cell content in NFATC2 ${ }^{-/}$and hematopoietic-depleted mice

While the number of initial or advanced lesions in the aortic arch of $L D L r^{-/}$and NFATC2 ${ }^{-/} / / L D L r^{-/-}$mice did not differ (data not shown), the average plaque size of advanced lesions was significantly increased in NFATC2 ${ }^{-/} / / \mathrm{LDLr}^{-/}$mice compared to $L D L r^{-/}$mice (Figure 1A). Analysis of plaque composition revealed significantly increased relative $\mathrm{CD}^{+} \mathrm{T}$-cell content in $\mathrm{NFATC2}{ }^{-/} / / \mathrm{LDLr}^{-/-}$mice compared to $L D L r^{-/-}$controls (Figure 1B).

Hematopoietic deficiency of NFATC2 resulted in similarly enhanced advanced lesion area (Figure $\mathbf{1 C}$ ), suggesting that hematopoietic NFATC2 depletion was responsible for the aggravated disease progression. Again, we did not observe any differences in the average initial lesion size between both groups (data not shown), indicating that NFATC2 deficiency predominantly impacts advanced plaque development. Similar to the whole body knockouts, NFATC2 deficiency in the hematopoietic-lineage resulted in a dramatic increase in lesional $\mathrm{CD}^{+}{ }^{+}$-cell content (Figure 1D). Relative CD45 ${ }^{+}$-leukocyte and $\mathrm{MAC3}^{+}$-macrophage numbers, collagen content, lipid core size as well as 
percentage cleaved caspase-3-positive cells did not differ between both groups of transplanted mice (Supplemental Figure II on page 89). Interestingly, the degree of calcification, characterized by plaque mineralization and the presence of intraplaque chondrocytes, was dramatically increased in NFATC2transplanted mice, compared with control mice (Figure 1E), which was not observed in NFATC2 $2^{-/} / / L D L r^{-/-}$mice (data not shown).

A

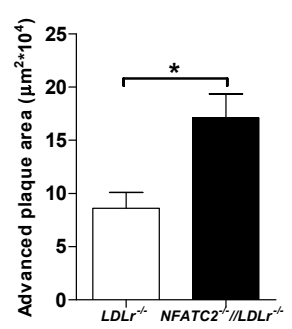

C

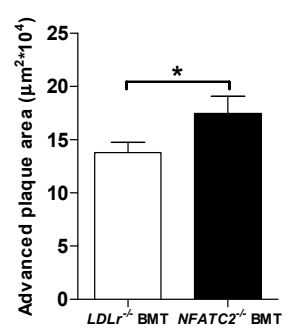

B

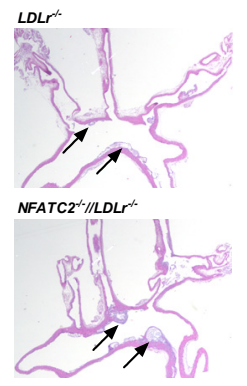

D

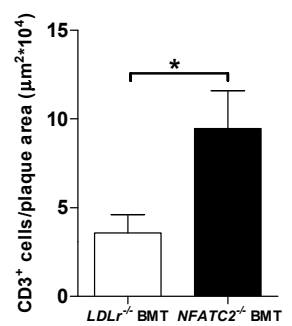

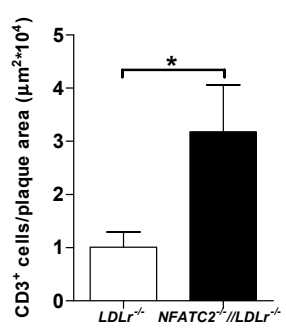

E

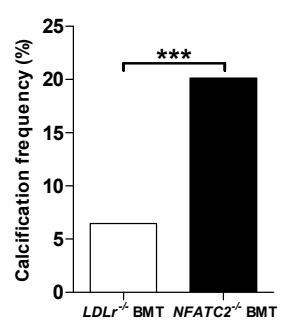

$L D L r^{\prime-}$

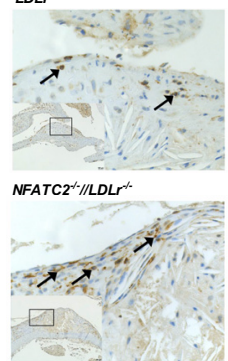

NFATC2 ${ }^{-/}$BMT

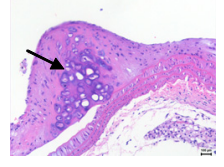

Figure 1. NFATC2 $^{-}$(top panels) and hematopoietic-depleted mice (bottom panels) showed increased advanced lesion size and T-cell content in the aortic arch. A, Area $\left(\mu \mathrm{m}^{2}\right)$ of advanced lesions measured in the aortic arch of $L D L r^{-/}$and $N F A T C 2^{--} / / L D L r^{-/}$mice and representative photographs of H\&E-stained aortic arches containing atherosclerotic plaques (arrows). B, Quantification of $\mathrm{CD}^{+}$T-cells, relative to plaque area, of lesions in the aortic arch of $L D L r^{-/}$and NFATC2 $\% / / L D L r^{--}$mice, and representative photographs of anti-CD3 T-cell staining (arrows). Insets show lower magnification. Similar area measurement $(\mathbf{C})$ and relative $\mathrm{CD}^{+}{ }^{+}$-cell content analysis (D) of plaques in the aortic arch of $L D L r^{-/}$- and NFATC2 ${ }^{--}$-BMT mice. E, The percentage of calcification, characterized by mineralization and the presence of chondrocytes (relative to noncalcified area), in plaques of NFATC2 ${ }^{--}$-BMT mice compared with $L D L r^{-/}$-BMT mice. H\&E-stained advanced plaque of NFATC2 $^{-}$-BMT mouse showing calcified cartilage (arrow). Bars represent mean $\pm \mathrm{SEM} ; * \mathrm{P}<0.05, * * * \mathrm{P}<0.001$. 


\section{NFATC2 $^{-/-}$led to a $\mathrm{Th}_{2} \mathrm{~T}_{\text {-cell }}$ response}

Intracellular flow-cytometric staining of the lineage-specific transcription factors Tbet and GATA3, critical for $\mathrm{Th}_{1^{-}}$and $\mathrm{Th}_{2}$-differentiation respectively, were performed and showed a significant increase in GATA3 expression and no difference in Thet expression in $\mathrm{CD}^{+}$T-cells in spleens of NFATC2 $\% / / L D L r^{-/}$ mice compared with control $L D L r^{-/}$mice (Figure 2A). In keeping, $\mathrm{PMA}$ /ionomycin-induced cytokine IFN- $\gamma$ expression in $\mathrm{CD} 4^{+}$and $\mathrm{CD} 8^{+} \mathrm{T}$-cells in vitro was significantly decreased in NFATC2 $2^{--} / / L D L r^{-1-}$ mice (Figure 2B-C), while that of IL-4 was undetectably low in both genotypes (data not shown). No differences were observed in the intracellular expression of transcription factor RoryT and cytokine IL-17 between NFATC2 ${ }^{-/} / / L D L r^{-/-}$and $L D L r^{-/}$mice, reflective of an unaltered $T h_{17}$ response (data not shown). The $\mathrm{Th}_{1}$ to $T h_{2}$ shifted immune response in NFATC2 ${ }^{-/}$mice could be confirmed in vivo as judged by the markedly increased GATA3 and IL-4 gene expression in spleen of NFATC2 ${ }^{-\gamma} / / L D L r^{--}$mice (Figure 2D). Thet and IFN- $\gamma$ expression was not significantly altered between NFATC2 $2^{-/} / / L D L r^{-/}$and $L D L r^{-/}$mice (data not shown). 
A

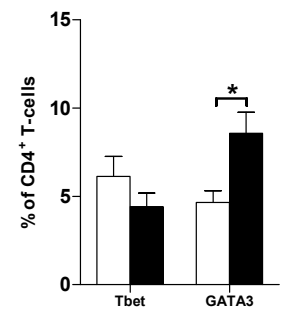

C

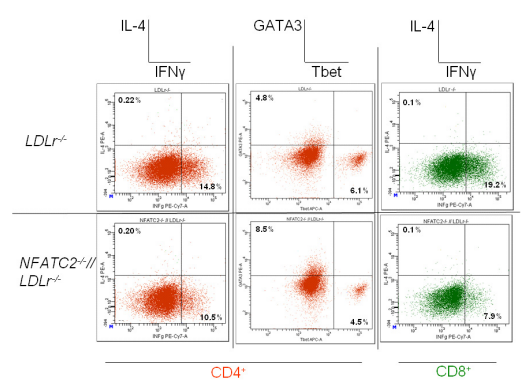

B

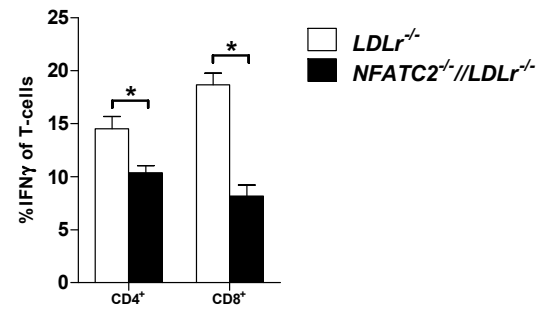

D

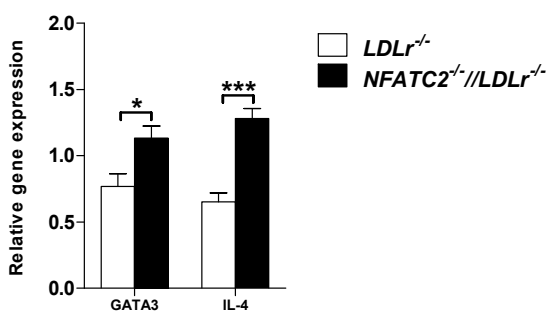

Figure 2. $\mathrm{Th}_{2}$ differentiation in spleen of $\mathrm{NFATC2}^{-/-}$mice. A, Flow cytometric analysis of Thet and GATA3, transcription factors responsible for a $\mathrm{Th}_{1}$ and $\mathrm{Th}_{2}$ response respectively, in splenic CD4 ${ }^{+}$ T-cells of $L D L r^{-/}$and NFATC2 $/ / / L D L r^{-/-}$mice. B, Flow-cytometric analysis of IFN- $\gamma$ level after in vitro stimulation with $\mathrm{PMA}$ /ionomycin of $\mathrm{CD}^{+}$and $\mathrm{CD} 8^{+}$splenocytes. C, Representative FACS plots of intracellular staining of transcription factors Tbet and GATA3, and cytokines IFN- $\gamma$ and IL4 of $\mathrm{CD}^{+}$and $\mathrm{CD}^{+}$T-cells. D, GATA3 and IL-4 gene expression (relative to the average expression level of house-keeping genes) in spleen of $\mathrm{NFATC2}^{-/} / / \mathrm{LDLr} \mathrm{r}^{-/}$mice compared to $\mathrm{LDLr} \mathrm{L}^{-/}$ mice. Bars represent mean $\pm \mathrm{SEM} ;{ }^{*} \mathrm{P}<0.05, * * * \mathrm{P}<0.001$.

\section{NFATC2 deficiency enhanced T-cell mitogenic response to anti-CD3 treatment}

The remarkable increase in plaque T-cell content prompted further investigation of T-cell phenotype and function. Therefore, single-cell suspensions of blood, spleen and lymph nodes of $\mathrm{NFATC2}^{-/}$mice were analyzed for lymphocyte subsets by FACS. Relative $\mathrm{CD}^{+} \mathrm{T}$-cell numbers were significantly elevated in spleen, but decreased in lymph nodes of NFATC2 ${ }^{-/}$ $/ / L D L r^{-/}$mice compared to $L D L r^{-/}$mice (Figure $3 \mathrm{~A}$ ). T-cells in blood, spleen and lymph nodes showed no changes in $\mathrm{CD}^{+}$to $\mathrm{CD} 8^{+}$ratio (data not shown). However, $\mathrm{CD} 4^{+} \mathrm{CD} 25^{-} \mathrm{T}$-cell numbers were significantly increased in spleen and lymph nodes of NFATC2 ${ }^{-/} / / L D L r^{-/}$mice (Figure 3B). Of note, no differences were observed in number of monocytes, granulocytes or natural killer cells between NFATC2 ${ }^{-/} / / L D L r^{-/}$and $L D L r^{-/-}$mice (data not shown). 
Relative $\mathrm{CD}^{+}{ }^{+}$-cell numbers in spleen and blood of $\mathrm{NFATC2}^{-}-\mathrm{BMT}$ mice were not altered compared with $L D L r^{-/}$-transplanted mice (Figure $3 \mathrm{C}$ ). Circulating T-cells in NFATC2 ${ }^{-}$-BMT mice displayed a sharply reduced $\mathrm{CD}^{+}$to $\mathrm{CD}^{+}$ratio (Figure 3D). Relative $\mathrm{CD} 4^{+}, \mathrm{CD}^{+}, \mathrm{CD} 4^{+} \mathrm{CD} 25^{+}$and $\mathrm{CD} 4^{+} \mathrm{CD} 25^{-}$of $\mathrm{CD}^{+}$ T-cell contents in spleen of NFATC2 ${ }^{-/}$-BMT mice remained unaffected (data not shown). Interestingly, while blood and spleen $\mathrm{CD}^{+}{ }^{+}$-cell numbers were not altered in $\mathrm{NFATC2}^{-}$-transplanted mice (Figure $3 \mathrm{C}$ ), $\mathrm{CD}^{+}$expression (mean fluorescent intensity) was markedly enhanced (Figure 3E). In keeping with this notion, the mitogenic response of $\mathrm{CD}^{+} \mathrm{CD} 25^{-} \mathrm{T}$-cells to anti-CD3 antibody treatment in vitro, as measured by incorporation of $\left[{ }^{3} \mathrm{H}\right]$ thymidine, was enhanced by a significant $24 \%$ in NFATC2 ${ }^{--}$T-cells (Figure 3F) pointing to an increased responsiveness of NFATC2 ${ }^{-/}$T-lymphocytes to anti-CD3 activation.

\section{Unchanged Treg-suppressive function}

The $\mathrm{CD}^{+} \mathrm{CD} 25^{+}$T-cell subset, which was significantly expanded in NFATC2 ${ }^{-1}$ BMT mice (Figure 3D), was enriched in $\mathrm{CD} 4^{+} \mathrm{CD} 25^{+}$Foxp $3^{+}$Tregs (blood) and $\mathrm{CD}^{+} \mathrm{CD} 25^{+}$Foxp3 $^{-}$activated T-cells (spleen) (Figure 4A). $\mathrm{CD}^{+} \mathrm{CD}_{2} 5^{+} \mathrm{Foxp}^{+}$ Tregs were also overrepresented in spleen and lymph nodes of FATC2 $^{-1}$ $/ / L D L r^{-/}$mice (Figure 4B). In agreement with the observed Treg expansion, gene expression of Foxp3, a critical transcription factor in Treg differentiation and function ${ }^{30,31}$, was seen to be upregulated in spleen of NFATC2 $\% / / L D L r^{-/}$ mice (Figure 4C). Considering the observed enhanced $\mathrm{CD} 4^{+} \mathrm{CD} 25^{-} \mathrm{T}$-cell responsiveness to CD3 stimulation (Figure 3F) and the increased Treg numbers, we investigated the suppressive capacity of Tregs. However, NFATC2 ${ }^{-}$- and $L D L r^{-/}$-BMT mice showed equal Treg function (Figure 4D). 
A

C

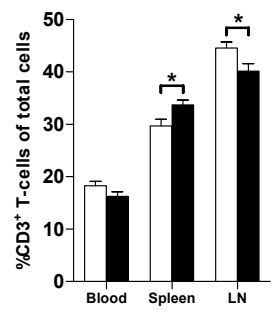

E
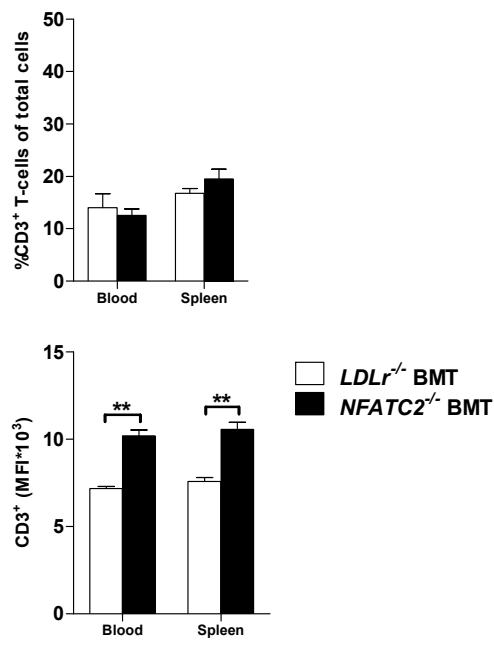

B

D
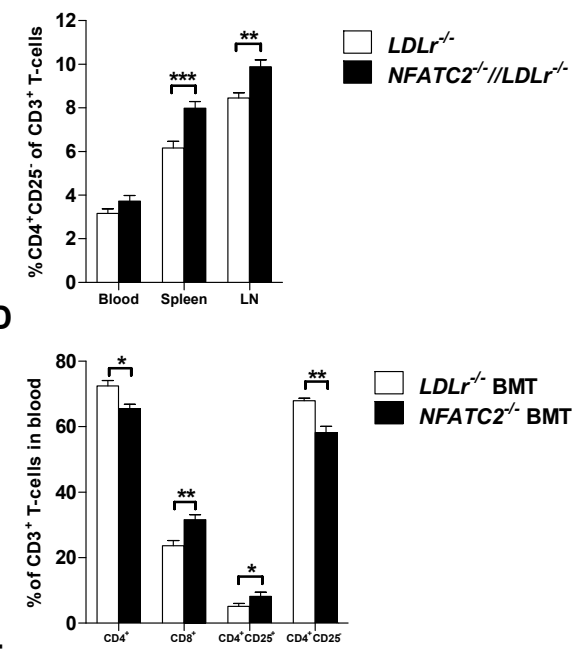

$\mathbf{F}$

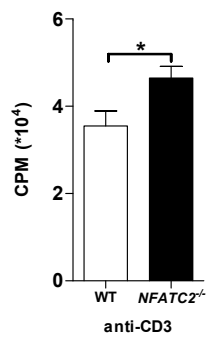

Figure 3. NFATC2 $^{-/}$(top panels) and hematopoietic deficiency (middle panels) altered Tlymphocyte pattern and enhanced mitogenic response to anti-CD3 treatment (bottom panels). A, Flow-cytometric analysis of the percentage $\mathrm{CD}^{+}{ }^{+} \mathrm{T}$-cells of total cells measured in circulation, spleen and lymph nodes (LN) of $L D L r^{-/}$and NFATC2 $2^{-/} / / L D L r^{-/-}$mice. B, The relative number of $\mathrm{CD}^{+} \mathrm{CD} 25^{-}$T-cells in blood, spleen and $\mathrm{LN}$ of $L D L r^{-/}$and NFATC2 $/ / / L D L r^{-/-}$mice. C, Percentage $\mathrm{CD}^{+}$T-cells in blood and spleen of NFATC2 ${ }^{-}$-BMT mice compared with $L D L r^{-\%}$-BMT mice. D, Flow cytometric analysis of $\mathrm{CD}^{+}, \mathrm{CD}^{+}, \mathrm{CD}^{+} \mathrm{CD} 25^{+}$and $\mathrm{CD} 4^{+} \mathrm{CD} 25^{-}$T-cell populations in blood of $\mathrm{LDLr}^{--}$-BMT and NFATC2 ${ }^{--}$-BMT mice. E, CD3 mean fluorescent intensity (MFI) of $\mathrm{CD}^{+}{ }^{+} \mathrm{T}_{\text {-cells in }}$ blood and spleen of $L D L r^{-/}$- and NFATC2 ${ }^{-/}$-BMT mice. F, Assessment of the proliferation of purified $C D 4^{+} \mathrm{CD} 25^{-}$T-cells $([3 \mathrm{H}]$ thymidine incorporation) after stimulation with anti-CD3 in the presence of purified WT CD11 $c^{+}$dendritic cells (counts per minute, CPM). Bars represent mean \pm SEM; * $\mathrm{P}<0.05, * * \mathrm{P}<0.01, * * * \mathrm{P}<0.001$. 
A

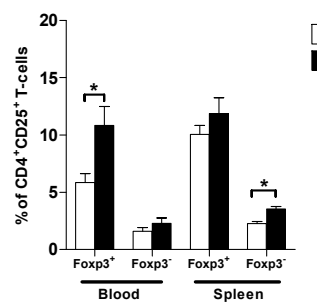

C

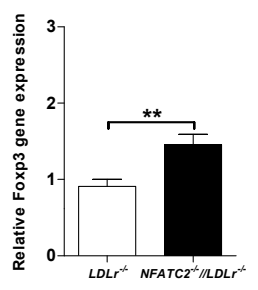

B

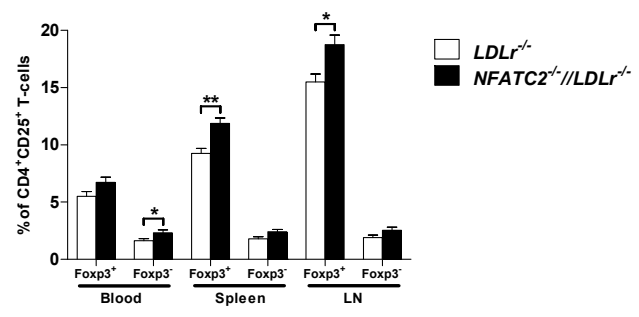

D

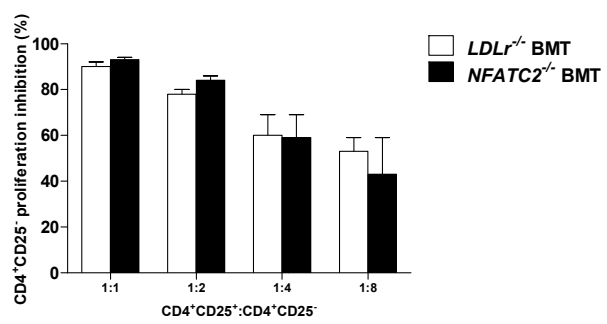

Figure 4. NFATC2 deficiency increased Treg numbers without changing Treg function. Flowcytometric analysis of the effect of hematopoietic NFATC2 depletion (A) and NFATC2 ${ }^{--}$(B) on $\mathrm{CD}^{+} \mathrm{CD} 25^{+}$Foxp $^{+}$and Foxp3 ${ }^{-}$T-cells in blood, spleen and lymph nodes (LN). C, Foxp3 gene expression level (relative to the average expression level of house-keeping genes) in spleen of $L D L r^{-/}$and NFATC2 ${ }^{-/} / / L D L r^{-/}$mice. D, Difference in regulatory T-cell function in suppressing Tcell proliferation. Inhibition of proliferation of $\mathrm{CD}^{+} \mathrm{CD} 25^{-}$T-cells after coculture with $\mathrm{CD} 4^{+} \mathrm{CD} 25^{+}$ Treg cells. Bars represent mean $\pm \mathrm{SEM} ;{ }^{*} \mathrm{P}<0.05,{ }^{* *} \mathrm{P}<0.01$.

Hematopoietic depletion and NFATC2 ${ }^{-}$resulted in enhanced effector/memory T-cell phenotype

Another feature of altered T-cell function in NFATC2 $\% / / L D L r^{-/}$mice was the decreased ratio of naïve T-cells, defined as $\mathrm{CD} 4{ }^{+} \mathrm{CD} 44^{\text {low }}{ }^{\mathrm{CD}} 62 \mathrm{~L}^{\text {high }} \mathrm{T}$-cells, to effector/memory ( $C D 44^{+} \mathrm{CD} 44^{\text {high }} \mathrm{CD} 62 \mathrm{~L}^{\text {low }}$ ) T-cells in blood, spleen and lymph nodes (Figure 5A-B). Of note, the $\mathrm{CD} 8^{+} \mathrm{T}$-cell population showed a comparable pattern with minor decreases and increases, respectively, in naïve and memory T-cell counts in blood, spleen and lymph nodes of NFATC2 $\% / / L D L r^{-/}$mice (data not shown).

Analysis of hematopoietic depletion of NFATC2 confirmed these findings, in that naïve ( $\left.\mathrm{CD} 4{ }^{+} \mathrm{CD} 44^{\text {low }} \mathrm{CD} 62 \mathrm{~L}^{\text {high }}\right) \mathrm{T}$-cells were significantly reduced $(8.7 \%)$ in blood of NFATC2 ${ }^{-}$-transplanted mice, while the effector/memory $\mathrm{CD} 4{ }^{+} \mathrm{CD} 44^{\text {high }} \mathrm{CD} 62 \mathrm{~L}^{\text {low }} \mathrm{T}$-cell subset was expanded by $42.3 \%$ (Figure $5 \mathrm{C}$ ). This ratio shift towards effector/memory T-cells was also apparent in the $\mathrm{CD} 8^{+} \mathrm{T}$ cell population in blood and spleen (data not shown). Not only the $\mathrm{CD}^{+}{ }^{+} \mathrm{T}$-cell 
population as a whole but also the $\mathrm{CD} 4^{+} \mathrm{CD} 25^{+} \mathrm{T}$-cell subset showed a significantly shifted ratio of naïve to effector/memory T-cells in blood and spleen of NFATC2 ${ }^{-1}$-BMT mice (Figure 5D). Interestingly, not only fewer T-cells were $\mathrm{CD}_{2} \mathrm{~L}^{+}$, also the mean $\mathrm{CD} 62 \mathrm{~L}$ expression of $\mathrm{CD} 4^{+}-, \mathrm{CD}^{+}$- and $\mathrm{CD} 4^{+} \mathrm{CD} 25^{+}-$ CD62 $\mathrm{L}^{\text {high }}$ T-cells was substantially reduced (Figure 5E). Furthermore, Western blot data showed no difference in the level of dephosphorylated NFATC1 between $L D L r^{-/}$and NFATC2 ${ }^{-/} / / L D L r^{-/}$splenocytes (data not shown), excluding the possibility of overcompensation. In addition, no significant alteration in expression of anergy-associated genes (Cblb and Egr2) was found (data not shown).

\section{NFATC2 deficiency reduced spleen engraftment, but enhanced homing of splenocytes to atherosclerotic lesions}

Given the marked and consistent skewing towards a migratory effector/memory T-cell phenotype in NFATC2 deficiency, we examined whether this shift accounted for the higher T-cell content in NFATC2 ${ }^{-1}$ atherosclerotic lesions. Therefore, $\mathrm{CSFE}^{+}$splenocytes isolated from NFATC2 ${ }^{--}$ and WT mice were injected into $A p o E^{-/}$recipients with established atherosclerotic lesions. Forty two hours after injection, $\mathrm{CFSE}^{+}$cells could be detected in recipient spleens as measured by FACS. In agreement with our hypothesis, recovery of $\mathrm{NFATC2}^{-/} \mathrm{CFSE}^{+}$cells in spleen was dramatically reduced compared to that of WT CFSE ${ }^{+}$splenocytes (Figure 6A). In contrast, the percentage of $\mathrm{CFSE}^{+}$cells of total cells in plaque was 2.7 fold higher in recipients that had received $\mathrm{NFATC2}^{-} \mathrm{CFSE}^{+}$splenocytes than in recipients receiving WT $\mathrm{CFSE}^{+}$splenocytes (Figure 6B). Thus, NFATC2 deficiency is associated with enhanced migration capacity of splenocytes to atherosclerotic lesions, while splenic grafting was reduced. 
A
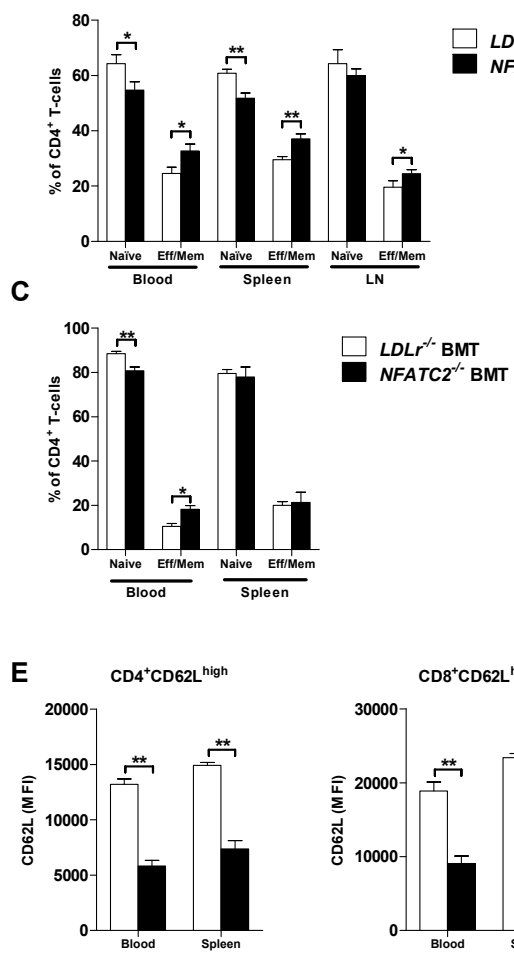

LDLF'

NFATC2-//LDL $r^{-1 / 2}$

B

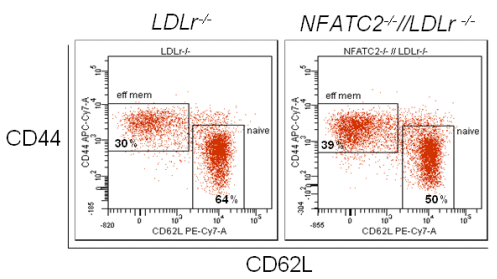

D
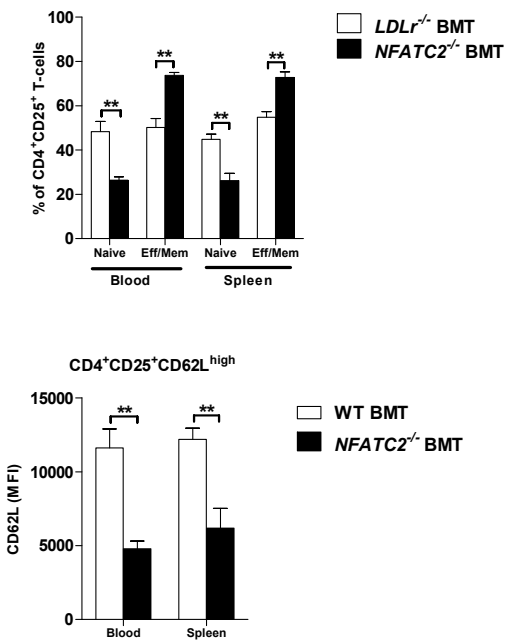

Figure 5. $\mathrm{NFATC2}^{-/}$(top panels) and hematopoietic depletion (lower panels) enhanced effector/memory T-cell phenotype. A, Flow-cytometric analysis of the percentage of naïve $\mathrm{CD} 4^{+}$ T-cells, defined as $\mathrm{CD} 44^{\text {low }}{ }^{\mathrm{CD} 62 \mathrm{~L}^{\text {high }}}$ and effector/memory (Eff/Mem) T-cells, defined as $\mathrm{CD} 44^{\text {high }} \mathrm{CD} 6 \mathrm{~L}^{\text {low }}$ in blood, spleen and lymph nodes (LN) of NFATC2 $\% / / L D L r^{-/}$mice compared with controls. B, FACS plots of splenocytes stained with anti-CD44 and anti-CD62L on gated CD4 ${ }^{+}$ cells. The percentage of naïve and effector/memory $\mathrm{CD}^{+}(\mathrm{C})$ and $\mathrm{CD}^{+} \mathrm{CD} 25^{+}$(D) T-cells in blood and spleen of $L D L r^{-1}$ - and NFATC2 ${ }^{-1}$-BMT mice. E, Flow-cytometric analysis of the effect of NFATC2-hematopoietic deficiency on CD62L mean fluorescent intensity (MFI) of $\mathrm{CD}^{+} \mathrm{CD}_{22} \mathrm{~L}^{\text {high }}$, $\mathrm{CD} 8^{+} \mathrm{CD} 62 \mathrm{~L}^{\text {high }}$ and $\mathrm{CD} 4^{+} \mathrm{CD} 25^{+} \mathrm{CD} 62 \mathrm{~L}^{\text {high }} \mathrm{T}$-cell subsets in blood and spleen. Bars represent mean $\pm \mathrm{SEM} ;{ }^{*} \mathrm{P}<0.05,{ }^{* *} \mathrm{P}<0.01$. 
A

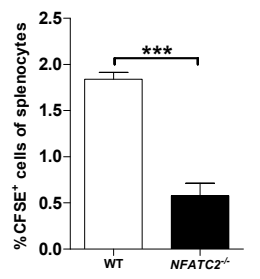

C

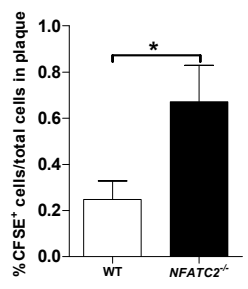

B

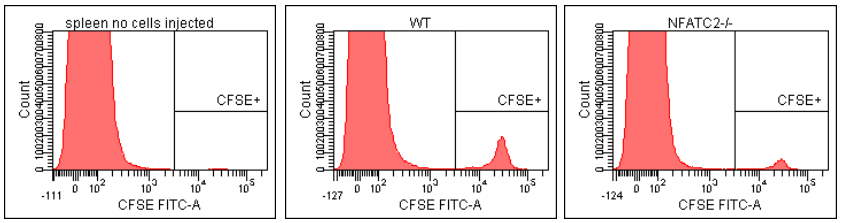

Figure 6. NFATC2 deficiency enhanced homing of splenocytes to atherosclerotic lesions. Flow cytometric analysis of $\mathrm{CFSE}^{+}$splenocytes relative to total cell number, isolated from either donor NFATC2 ${ }^{--}$or WT mice, in spleen (A, B) and atherosclerotic aortic arch lesions (C) of recipient $A p o E^{-/-}$mice. Bars represent mean $\pm \mathrm{SEM} ; * \mathrm{P}<0.05, * * * \mathrm{P}<0.001$.

\section{Discussion}

A critical regulator of immune responses, NFAT, contributes to a variety of inflammatory and autoimmune disorders. The recent finding that NFAT activation was indispensable for Treg function ${ }^{11,22,23}$ and that NFATC2 deficiency led to Th2-biased immune responses ${ }^{12,24,25}$, and the prominent role of T-cells in atherosclerosis ${ }^{26}$, suggested a role of this transcription factor in this disease as well. Indeed, we have previously shown that inhibition of calcineurin/NFAT signaling by low-dose FK506 inhibited the initiation and progression of collar-induced atherosclerosis. ${ }^{20,21}$ This led us to investigate the role of a major mediator in NFAT signaling in T-cells, NFATC2, in atherosclerosis.

Contrary to our expectations, NFATC2 ${ }^{--}$and hematopoietic depletion led to dramatically increased lesional $\mathrm{CD}^{+} \mathrm{T}$-cell content and exacerbated the atherogenic response, and in particular advanced lesion development. As expected, NFATC2 $\% / / L D L r^{-/-}$mice showed an increase in $\mathrm{Th}_{2}$-reponse in spleen, as witnessed by the upregulated transcription factor GATA3 and cytokine IL-4, 
as well as downregulated $\mathrm{Th}_{1}$-cytokine (IFN- - ) expression, an effect that is generally deemed atheroprotective. This is concordant with previous reports that NFATC2-deficient mice exhibited a $\mathrm{Th}_{2}$-dominated pro-allergic phenotype. ${ }^{12-15}$ The nuclear balance between NFAT-family members and costimulatory transcription factors was deemed instrumental in coordinated transcriptional regulation of Th-immune programs. While plaque T-cells are thought to display a pro-atherogenic $\mathrm{Th}_{1}$ phenotype ${ }^{32}$, our study showed that NFATC2 aggravated the atherogenic response due to or despite an overt splenic $\mathrm{Th}_{2}$ polarization of T-cell responses. In support of the former, both $A p o E^{/-} / / I L-4^{-/}$mice ${ }^{33}$ and $L D L r^{-/}$mice reconstituted with IL-4-deficient bone marrow $^{34}$ showed a marked decrease in atherosclerosis, illustrating the dichotomous activity of $\mathrm{Th}_{2}$ cytokines in atherosclerosis.

A consistent feature of NFATC2 deficiency was the observed enrichment in $\mathrm{CD}^{+}{ }^{+} \mathrm{CD} 25^{+}$Foxp $^{+}$Treg subset. Interestingly, NFATC2 has been shown to directly interact with Foxp3 after T-cell receptor (TCR) activation ${ }^{35}$ as part of the transcriptional program required for Foxp3 promoter transactivation, and for proper Treg function ${ }^{11}$. In fact, the balance between initiation of an inflammatory $\mathrm{T}$ (effector)-cell versus Treg response depended critically on the nuclear concentration of NFAT to interact with Foxp3 or activator protein 1 (AP1). ${ }^{36}$ To illustrate this notion, pharmacological inhibition of NFAT dephosphorylation with CsA in $\mathrm{CD}^{+}{ }^{+} \mathrm{CD} 25^{-}$T-cells favored Treg activity. ${ }^{22}$ In this study, however, while $\mathrm{CD} 4^{+} \mathrm{CD} 25^{+} \mathrm{Foxp}^{+}$Treg numbers were augmented in NFATC2 $\%$, we found that their intrinsic suppressive activity was unaltered. Thus, the stronger proliferative response of $\mathrm{NFATC}^{-/}$responder T-cells to in vitro CD3 activation was not attributable to compromised Treg function with NFATC2 deficiency, but might be associated with the enhanced CD3 expression on T-lymphocytes in these mice reflecting a lower threshold for TCR activation. This is in keeping with the previously suggested involvement of NFATC2 in the modulation of TCR responsiveness, as T-cells from NFATC2 and C3-DKO mice showed increased proliferation in response to CD3 stimulation, even without CD28 costimulation. ${ }^{37}$ Thus in the absence of NFATC2 the threshold is lowered, resulting in increased proliferation and activation, and attenuated responsiveness to Treg-mediated suppression. As Treg function remained intact in NFATC2-deficiency, Treg function in itself appeared not exclusively dependent on NFATC2-transcriptional activity. In normolipidemic mice the 
$\mathrm{CD}^{+} \mathrm{CD} 25^{+}$T-cell subset largely comprises Foxp ${ }^{+} \mathrm{Tregs}^{38}$, but this does not necessarily hold for high-fat fed $L D L r^{-/}$recipients. The $\mathrm{CD} 4^{+} \mathrm{CD} 25^{+} \mathrm{CD} 44^{\text {high }} \mathrm{T}$-cell subset encompasses Foxp3- effector T-cells as well as self-antigen specific Foxp $3^{+}$memory Tregs, which were recently reported to constitute a first line of tolerogenic control to self antigens. ${ }^{39}$ Therefore, the Foxp3 ${ }^{-}$effector subset skewed T-cell differentiation seen in NFATC2 deficiency, paralleled by a concomitant increase in memory Treg, may possibly represent a compensatory response to control T-cell activity.

Another intriguing observation in this study was that NFATC2 deficiency resulted in enhanced effector/memory T-cell numbers characterized by $\mathrm{CD} 44^{\text {high }} \mathrm{CD} 62^{\text {low }}$ and reduced levels of the $\mathrm{CD} 44^{\text {low }} \mathrm{CD} 62 \mathrm{~L}^{\text {high }}$ naïve T-cell phenotype in $\mathrm{CD}^{+}$and $\mathrm{CD} 4^{+} \mathrm{CD} 25^{+} \mathrm{T}$-cells. This observation fits well with the earlier reported effector/memory phenotype displayed by peripheral T-cells from NFATC2/C3 compound knockout mice, featuring elevated CD44 expression. ${ }^{40}$ NFATC2 indeed is expressed and operational in memory CD4 ${ }^{+} \mathrm{T}$ cells where it is, amongst others, required for IL-2 production. ${ }^{41}$ Enhanced NFATC1/C2 transcriptional activity was considered instrumental in the rapid response of memory $\mathrm{CD}^{+}$T-cells to antigen stimulation by inducing cell migration and cytokine expression and release..$^{41}$ Our study thus adds to these findings, identifying NFATC2 as key suppressor of $\mathrm{CD} 44^{\text {high }} \mathrm{CD} 62 \mathrm{~L}^{\text {low }}$ effector/memory T-cell differentiation.

CD44 expression is important for effector/memory T-cell extravasation at inflammatory sites ${ }^{42}$, whereas CD62L is responsible for homing of naïve Tcells to and retention in lymph nodes. ${ }^{43}$ Central memory T-cells, unlike naïve Tcells, were able to migrate to inflammatory sites and subsequently responded rapidly to antigens by secreting large amounts of effector cytokines such as IL4, IL-5 and IFN- - , whereas naïve T-cells mainly traffic to lymph nodes. ${ }^{44-47}$ Our in vivo trafficking studies showed that NFATC2 ${ }^{-}$splenocytes preferentially home to the atherosclerotic lesion compared with WT splenocytes and the associated impairment of spleen grafting points in that direction. The increased plaque homing capacity and plaque $\mathrm{CD}^{+}{ }^{+}$T-cell content in NFATC2 deficiency may thus be explained by the profoundly shifted balance between naïve and effector/memory T-cells, the predominant subset in chronically inflamed tissue. ${ }^{48}$ 
How exactly NFATC2 deficiency tunes effector/memory function remains elusive. As reported, T-cells lacking NFATC2 were resistant to anergy induction and showed drastically reduced expression of anergy-associated genes, such as Cblb, Egr2, Egr3, Grail and Caspase 3. ${ }^{49,} 50$ One might speculate that the failure to undergo T-cell anergy could have contributed to the observed expansion of the effector/memory T-cell subset and to the proliferative response in NFATC2 ${ }^{-/}$mice, as anergy renders the TCR uncoupled from down-stream signaling pathways preventing proliferation and cytokine expression in response to subsequent antigen encounter. However, we did not observe any major changes in anergy-associated gene expression.

In conclusion, although NFAT-family members are critical activators of immune responses and NFATC2 deficiency in mice resulted in a $\mathrm{Th}_{2}$-biased Tcell response, deficiency in NFATC2 in atherosclerosis-prone $L D L r^{-/}$mice aggravated rather than ameliorated atherosclerosis. NFATC2-deficient T-cells displayed an augmented proliferative response to CD3 stimulation and an effector/memory phenotype, and showed robust accumulation in atherosclerotic lesions, which could well have contributed to the surprising, aggravated atherogenic response in NFATC2 deficiency. 


\section{Supplemental data}

Supplemental Table I. Forward and reverse primer sequences of genes tested by qPCR.

\begin{tabular}{|c|c|c|}
\hline & Forward primer (5'-3') & Reverse primer (5'-3') \\
\hline Tbet & GGGAACCGCTTATATGTCCA & GGGCTGGTACTTGTGGAGAG \\
\hline IFN-Y & TGGCTGTTTCTGGCTGTTACTG & GCTCTGCAGGATTTTCATGTCA \\
\hline GATA3 & CAGCTGCCAGATAGCATGAA & GCAGGCATTGCAAAGGTAGT \\
\hline IL-4 & ACGTCCTCACAGCAACGAAGA & AATATGCGAAGCACCTTGGAA \\
\hline Foxp3 & CCAGTCTGGAATGGGTGTCC & CTGCTTGGCAGTGCTTGAGA \\
\hline Cblb & ACAGGCTGGCGAGTGTTC & GAGCCTGGCGATGTGACT \\
\hline Egr2 & CTACCCGGTGGAAGACCTC & AATGTTGATCATGCCATCTCC \\
\hline Cyclophilin & CAAATGCTGGACCAAACACAA & TTCACСТTCССАAАGACСАСАТ \\
\hline $18 S$ & GTAACCCGTTGAACCCCATT & CCATCCAATCGGTAGTAGCG \\
\hline
\end{tabular}

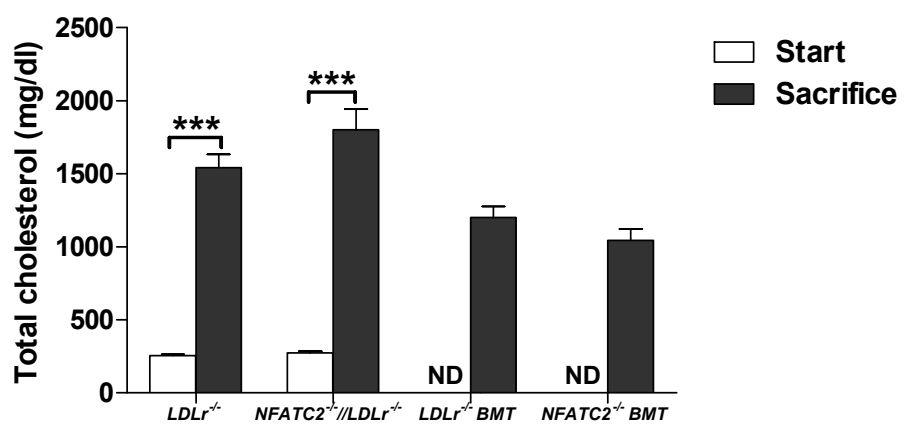

Supplemental Figure I. No difference in total cholesterol between control and NFATC2 ${ }^{-/}$or -BMT mice. Differences in total cholesterol levels at the start of the experiment and time of sacrifice of $L D L r^{-/}$and NFATC2 $\% / / L D L r^{-/}$mice, and $L D L r^{-/}$- and NFATC2 ${ }^{--}$-BMT mice. Bars represent mean \pm $\mathrm{SEM} ;{ }^{* * *} \mathrm{P}<0.001$. ND means not determined. 
A

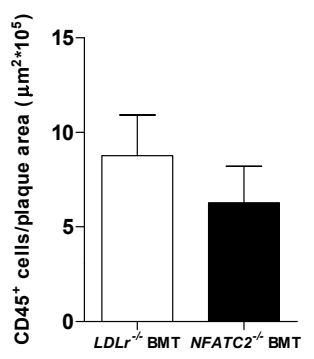

D

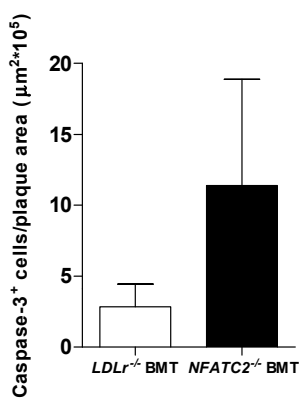

B

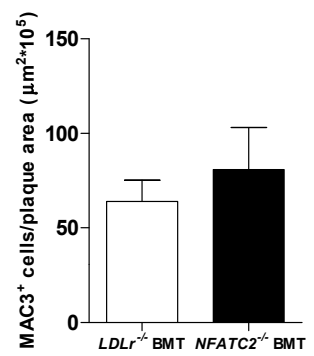

E

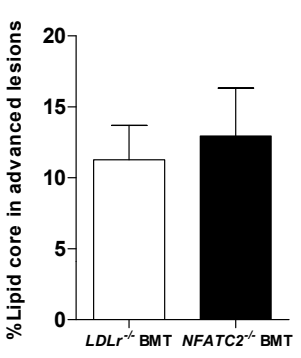

C

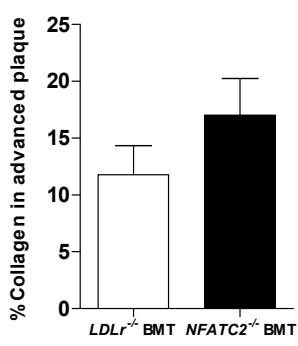

Supplemental Figure II. Influence of hematopoietic NFATC2 deficiency on plaque composition. Leukocyte content $\left(\mathrm{CD} 45^{+}\right.$staining, A) and macrophage content $\left(\mathrm{MAC3}^{+}\right.$staining, B) relative to advanced lesion area were not significantly different between NFATC2 ${ }^{-1}$-BMT and $L D L r^{-/}$-BMT mice. C, Percentage collagen content in advanced plaques, measured by Sirius red staining, and (D) number of cells positive for cleaved caspase-3 relative to advanced lesion area, as well as (E) the percentage lipid core area. Bars represent mean \pm SEM. 


\section{References}

1. Macian F. Nfat proteins: Key regulators of t-cell development and function. Nature reviews. Immunology. 2005;5:472-484

2. Muller MR, Rao A. Nfat, immunity and cancer: A transcription factor comes of age. Nature reviews. Immunology. 2010;10:645-656

3. Kiani A, Habermann I, Haase M, Feldmann S, Boxberger S, Sanchez-Fernandez MA, Thiede $C$, Bornhauser $M$, Ehninger $G$. Expression and regulation of nfat (nuclear factors of activated $\mathrm{t}$ cells) in human cd34+ cells: Down-regulation upon myeloid differentiation. Journal of leukocyte biology. 2004;76:1057-1065

4. Fric J, Lim CX, Koh EG, Hofmann B, Chen J, Tay HS, Mohammad Isa SA, Mortellaro A, Ruedl C, Ricciardi-Castagnoli P. Calcineurin/nfat signalling inhibits myeloid haematopoiesis. EMBO molecular medicine. 2012;4:269-282

5. Rao A, Luo C, Hogan PG. Transcription factors of the nfat family: Regulation and function. Annual review of immunology. 1997;15:707-747

6. Timmerman LA, Healy JI, Ho SN, Chen L, Goodnow CC, Crabtree GR. Redundant expression but selective utilization of nuclear factor of activated $t$ cells family members. J Immunol. 1997;159:2735-2740

7. Baine I, Abe BT, Macian F. Regulation of t-cell tolerance by calcium/nfat signaling. Immunological reviews. 2009;231:225-240

8. Masuda ES, Imamura R, Amasaki Y, Arai K, Arai N. Signalling into the t-cell nucleus: Nfat regulation. Cellular signalling. 1998;10:599-611

9. Hermann-Kleiter N, Baier G. Nfat pulls the strings during $\mathrm{cd} 4+\mathrm{t}$ helper cell effector functions. Blood. 2010;115:2989-2997

10. Brogdon JL, Leitenberg $\mathrm{D}$, Bottomly $\mathrm{K}$. The potency of tcr signaling differentially regulates nfatc/p activity and early il-4 transcription in naive cd4+t cells. J Immunol. 2002;168:3825-3832

11. Wu Y, Borde $M$, Heissmeyer V, Feuerer M, Lapan AD, Stroud JC, Bates DL, Guo L, Han A, Ziegler SF, Mathis D, Benoist C, Chen L, Rao A. Foxp3 controls regulatory t cell function through cooperation with nfat. Cell. 2006;126:375-387

12. Schuh K, Kneitz B, Heyer J, Siebelt F, Fischer C, Jankevics E, Rude E, Schmitt E, Schimpl A, Serfling E. Nf-atp plays a prominent role in the transcriptional induction of th2-type lymphokines. Immunology letters. 1997;57:171-175

13. Hodge MR, Ranger AM, Charles de la Brousse F, Hoey T, Grusby MJ, Glimcher LH. Hyperproliferation and dysregulation of il-4 expression in nf-atp-deficient mice. Immunity. 1996;4:397-405

14. Xanthoudakis S, Viola JP, Shaw KT, Luo C, Wallace JD, Bozza PT, Luk DC, Curran T, Rao A. An enhanced immune response in mice lacking the transcription factor nfat1. Science. 1996;272:892-895

15. Viola JP, Kiani A, Bozza PT, Rao A. Regulation of allergic inflammation and eosinophil recruitment in mice lacking the transcription factor nfat1: Role of interleukin-4 (il-4) and il-5. Blood. 1998;91:2223-2230

16. Heeneman S, Donners MM, Bai L, Daemen MJ. Drug-induced immunomodulation to affect the development and progression of atherosclerosis: A new opportunity? Expert review of cardiovascular therapy. 2007;5:345-364

17. Daum S, Sahin E, Jansen A, Heine B, Riecken EO, Zeitz M, Schmidt W. Adult autoimmune enteropathy treated successfully with tacrolimus. Digestion. 2003;68:8690 
18. Larsen FS, Vainer B, Eefsen M, Bjerring PN, Adel Hansen B. Low-dose tacrolimus ameliorates liver inflammation and fibrosis in steroid refractory autoimmune hepatitis. World journal of gastroenterology : WJG. 2007;13:3232-3236

19. Yu H, van Berkel TJ, Biessen EA. Therapeutic potential of vivit, a selective peptide inhibitor of nuclear factor of activated $t$ cells, in cardiovascular disorders. Cardiovascular drug reviews. 2007;25:175-187

20. Bai L, Gabriels K, Wijnands E, Rousch M, Daemen MJ, Tervaert JW, Biessen EA, Heeneman S. Low- but not high-dose fk506 treatment confers atheroprotection due to alternative macrophage activation and unaffected cholesterol levels. Thrombosis and haemostasis. 2010;104:143-150

21. Donners MM, Bot I, De Windt LJ, van Berkel TJ, Daemen MJ, Biessen EA, Heeneman S. Low-dose fk506 blocks collar-induced atherosclerotic plaque development and stabilizes plaques in apoe-/- mice. American journal of transplantation : official journal of the American Society of Transplantation and the American Society of Transplant Surgeons. 2005;5:1204-1215

22. Sumpter TL, Payne KK, Wilkes DS. Regulation of the nfat pathway discriminates $\mathrm{cd} 4+\mathrm{cd} 25+$ regulatory $\mathrm{t}$ cells from $\mathrm{cd} 4+\mathrm{cd} 25$ - helper $\mathrm{t}$ cells. Journal of leukocyte biology. 2008;83:708-717

23. Torgerson TR, Genin A, Chen $C$, Zhang $M$, Zhou B, Anover-Sombke S, Frank MB, Dozmorov I, Ocheltree E, Kulmala $P$, Centola $M$, Ochs HD, Wells AD, Cron RQ. Foxp3 inhibits activation-induced nfat2 expression in t cells thereby limiting effector cytokine expression. J Immunol. 2009;183:907-915

24. Kiani A, Garcia-Cozar FJ, Habermann I, Laforsch S, Aebischer T, Ehninger G, Rao A. Regulation of interferon-gamma gene expression by nuclear factor of activated $t$ cells. Blood. 2001;98:1480-1488

25. Rengarajan J, Tang B, Glimcher LH. Nfatc 2 and nfatc3 regulate $t(h) 2$ differentiation and

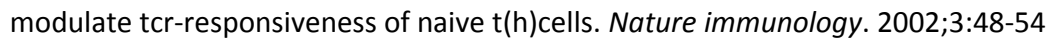

26. Daugherty A, Rateri DL. T lymphocytes in atherosclerosis: The yin-yang of th1 and th2 influence on lesion formation. Circulation research. 2002;90:1039-1040

27. Kanters E, Pasparakis M, Gijbels MJ, Vergouwe MN, Partouns-Hendriks I, Fijneman RJ, Clausen BE, Forster I, Kockx MM, Rajewsky K, Kraal G, Hofker MH, de Winther MP. Inhibition of nf-kappab activation in macrophages increases atherosclerosis in Idl receptor-deficient mice. The Journal of clinical investigation. 2003;112:1176-1185

28. Lutgens E, Gijbels M, Smook M, Heeringa P, Gotwals P, Koteliansky VE, Daemen MJ. Transforming growth factor-beta mediates balance between inflammation and fibrosis during plaque progression. Arteriosclerosis, thrombosis, and vascular biology. 2002;22:975-982

29. Taleb S, Herbin O, Ait-Oufella H, Verreth W, Gourdy P, Barateau V, Merval R, Esposito $B$, Clement $K$, Holvoet $P$, Tedgui A, Mallat Z. Defective leptin/leptin receptor signaling improves regulatory $\mathrm{t}$ cell immune response and protects mice from atherosclerosis. Arteriosclerosis, thrombosis, and vascular biology. 2007;27:2691-2698

30. Hori S, Nomura T, Sakaguchi S. Control of regulatory t cell development by the transcription factor foxp3. Science. 2003;299:1057-1061

31. Fontenot JD, Gavin MA, Rudensky AY. Foxp3 programs the development and function of cd4+cd25+ regulatory t cells. Nature immunology. 2003;4:330-336

32. Ponnuswamy $P$, Van Vre EA, Mallat Z, Tedgui A. Humoral and cellular immune responses in atherosclerosis: Spotlight on b- and t-cells. Vascular pharmacology. 2012;56:193-203

33. Davenport P, Tipping PG. The role of interleukin-4 and interleukin-12 in the progression of atherosclerosis in apolipoprotein e-deficient mice. The American journal of pathology. 2003;163:1117-1125 
34. King VL, Szilvassy SJ, Daugherty A. Interleukin-4 deficiency decreases atherosclerotic lesion formation in a site-specific manner in female Idl receptor-/- mice. Arteriosclerosis, thrombosis, and vascular biology. 2002;22:456-461

35. Mantel PY, Ouaked N, Ruckert B, Karagiannidis C, Welz R, Blaser K, Schmidt-Weber CB. Molecular mechanisms underlying foxp3 induction in human t cells. J Immunol. 2006;176:3593-3602

36. Rudensky AY, Gavin M, Zheng Y. Foxp3 and nfat: Partners in tolerance. Cell. 2006;126:253-256

37. Bopp T, Palmetshofer A, Serfling E, Heib V, Schmitt S, Richter C, Klein M, Schild H, Schmitt E, Stassen M. Nfatc2 and nfatc3 transcription factors play a crucial role in suppression of $\mathrm{cd} 4+\mathrm{t}$ lymphocytes by $\mathrm{cd} 4+\mathrm{cd} 25+$ regulatory $\mathrm{t}$ cells. The Journal of experimental medicine. 2005;201:181-187

38. Kuniyasu $Y$, Takahashi T, Itoh M, Shimizu J, Toda G, Sakaguchi S. Naturally anergic and suppressive $\mathrm{cd} 25(+) \mathrm{cd} 4(+) \mathrm{t}$ cells as a functionally and phenotypically distinct immunoregulatory t cell subpopulation. International immunology. 2000;12:1145-1155

39. Darrasse-Jeze G, Bergot AS, Durgeau A, Billiard F, Salomon BL, Cohen JL, Bellier B, Podsypanina K, Klatzmann D. Tumor emergence is sensed by self-specific cd44hi memory tregs that create a dominant tolerogenic environment for tumors in mice. The Journal of clinical investigation. 2009;119:2648-2662

40. Ranger AM, Oukka M, Rengarajan J, Glimcher LH. Inhibitory function of two nfat family members in lymphoid homeostasis and th2 development. Immunity. 1998;9:627-635

41. Dienz O, Eaton SM, Krahl TJ, Diehl S, Charland C, Dodge J, Swain SL, Budd RC, Haynes L, Rincon M. Accumulation of nfat mediates il-2 expression in memory, but not naive, $\mathrm{cd} 4+\mathrm{t}$ cells. Proceedings of the National Academy of Sciences of the United States of America. 2007;104:7175-7180

42. DeGrendele HC, Estess $\mathrm{P}$, Siegelman $\mathrm{MH}$. Requirement for cd44 in activated $\mathrm{t}$ cell extravasation into an inflammatory site. Science. 1997;278:672-675

43. Warnock RA, Askari S, Butcher EC, von Andrian UH. Molecular mechanisms of lymphocyte homing to peripheral lymph nodes. The Journal of experimental medicine. 1998;187:205-216

44. Kedl RM, Mescher MF. Qualitative differences between naive and memory t cells make a major contribution to the more rapid and efficient memory cd8+t cell response. $J$ Immunol. 1998;161:674-683

45. Rogers PR, Dubey C, Swain SL. Qualitative changes accompany memory $\mathrm{t}$ cell generation: Faster, more effective responses at lower doses of antigen. $J$ Immunol. 2000;164:2338-2346

46. Berard M, Tough DF. Qualitative differences between naive and memory $\mathrm{t}$ cells. Immunology. 2002;106:127-138

47. Sallusto F, Geginat J, Lanzavecchia A. Central memory and effector memory $t$ cell subsets: Function, generation, and maintenance. Annual review of immunology. 2004;22:745-763

48. Oppenheimer-Marks N, Lipsky PE. Migration of naive and memory t cells. Immunology today. 1997; 18:456-457

49. Soto-Nieves N, Puga I, Abe BT, Bandyopadhyay S, Baine I, Rao A, Macian F. Transcriptional complexes formed by nfat dimers regulate the induction of $t$ cell tolerance. The Journal of experimental medicine. 2009;206:867-876

50. Macian F, Garcia-Cozar F, Im SH, Horton HF, Byrne MC, Rao A. Transcriptional mechanisms underlying lymphocyte tolerance. Cell. 2002;109:719-731 




\section{chapter four}

\section{Irradiation of existing atherosclerotic lesions increased inflammation by favoring pro-inflammatory macrophàges}

Karen Gabriels, Saske Hoving, Marion J. Gijbels, Jeffrey F. Pol, Johannes A. te Poele, Erik A.L. Biessen, Mat J.A.P. Daemen, Fiona A. Stewart, Sylvia Heeneman

Submitted for publication 


\section{Abstract}

Background and purpose: Recent studies have shown an increased incidence of localized atherosclerosis and subsequent cardiovascular events in cancer patients treated with thoracic radiotherapy. We previously demonstrated that irradiation accelerated the development of atherosclerosis and predisposed to an inflammatory plaque phenotype in young hypercholesterolemic $A p o E^{-1}$ mice. However, as older cancer patients already have early or advanced stages of atherosclerosis at the time of radiotherapy, we investigated the effects of irradiation on the progression of existing atherosclerotic lesions in vivo.

Material and methods: $A p o E^{-1}$ mice (28 weeks old) received local irradiation with $14 \mathrm{~Gy}$ or $0 \mathrm{~Gy}$ (sham-treated) at the aortic arch and were examined after 4 and 12 weeks for atherosclerotic lesions, plaque size and phenotype. Moreover, we investigated the impact of irradiation on macrophage phenotype (pro- or anti-inflammatory) and function (efferocytotic capacity, i.e. clearance of apoptotic cells) in vitro.

Results: Irradiation of existing lesions in the aortic arch resulted in smaller, macrophage-rich plaques with intraplaque hemorrhage and increased apoptosis. In keeping with the latter, in vitro studies revealed augmented polarization towards pro-inflammatory macrophages after irradiation and reduced efferocytosis by anti-inflammatory macrophages. In addition, considerably more lesions in irradiated mice were enriched in proinflammatory macrophages.

Conclusions: Irradiation of existing atherosclerotic lesions led to smaller but more inflamed plaques, with increased numbers of apoptotic cells, most likely due to a shift towards pro-inflammatory macrophages in the plaque. 


\section{Introduction}

Cardiovascular disease (CVD) and cancer are the two leading causes of morbidity and mortality in industrialized societies. ${ }^{1}$ Although the number of patients diagnosed with cancer grows continuously, screening and treatment have improved, leading to increased survival rates. At least half of all long-term cancer survivors will have received radiotherapy. As a consequence, new challenges are emerging due to the development of secondary illnesses caused by radiotherapy. Survivors of Hodgkin's Lymphoma or breast cancer have higher risk of stroke and coronary heart disease. ${ }^{2-7}$ This is partly due to vascular damage and sustained inflammation leading to atherothrombosis, decades after receiving thoracic radiotherapy. Most radiotherapy treatments for breast cancer deliver more than $40 \mathrm{~Gy}$ in total to the tumor bed. Although only a small part of the heart is usually exposed to this high dose, additional research dissecting the underlying causes of radiation-induced CVD is crucial for developing specific intervention therapies.

One of the main causes of cardiovascular morbidity and mortality is atherosclerosis; it is a chronic lipid-driven inflammatory disorder of the arterial wall that can give rise to acute atherothrombotic events due to plaque erosion or rupture. ${ }^{8}$ Whereas wild-type mice have very low cholesterol levels and are resistant to atherosclerosis, hypercholesterolemic apolipoprotein E-knockout $\left(A p O E^{-}\right)$mice have elevated levels of total cholesterol and low-density lipoproteins (LDL) and develop atherosclerotic lesions spontaneously with age. As we have shown previously, local irradiation of the carotid arteries with a single dose of $14 \mathrm{~Gy}$ accelerated the progression of atherosclerosis in young $A p o E^{\prime-}$ mice and predisposed to macrophage-rich, thrombotic plaques, with less collagen, all features of a rupture-prone plaque. ${ }^{9,} 10$ Clinically relevant fractionated schedules of $20 \times 2$ Gy to the carotid artery resulted in a similar plaque phenotype in $A p o E^{-1}$ mice compared to a single-dose treatment (14 Gy). ${ }^{9}$ Furthermore, local cardiac irradiation of $A p o E^{-/}$mice induced an inflammatory response and microvascular damage, and enhanced atherosclerosis development in coronary arteries. ${ }^{11}$

In the absence of monocytes/macrophages, hypercholesterolemia is not sufficient to drive the pathologic process of atherosclerosis, indicating that macrophages exert essential functions during atherogenesis. ${ }^{12}$ They are the 
major cellular components of an atherosclerotic lesion and can impact plaque progression and stability by producing inflammatory mediators, regulating cholesterol metabolism, recruiting vascular smooth muscle cells (vSMCs), inducing lipid necrotic core formation, and producing matrix metalloproteinases (MMPs) and reactive oxygen species (ROS). ${ }^{13,}{ }^{14}$ Macrophages have remarkable plasticity that allows them to efficiently respond to different micro-environmental signals and to change their phenotype. Their physiology can also be markedly altered by both innate and adaptive immune responses. ${ }^{15,16}$ In the last few years, it has become accepted that macrophages can reversibly polarize into two main phenotypes, classically- (M1 phenotype) and alternatively-activated (M2 phenotype) macrophages, responsible for promoting and resolving inflammation respectively. ${ }^{17-20}$ Classically-activated macrophages are generated by proatherogenic stimuli and support a T-helper (Th) ${ }_{1}$-immune response, by producing pro-inflammatory cytokines as well as ROS and nitrogen intermediates through inducible nitric oxide synthase (iNOS) expression. In contrast, alternatively-activated macrophages are induced by $\mathrm{Th}_{2}$-related cytokines and secrete anti-inflammatory cytokines and upregulate scavenger receptors and arginase-1. M1- and M2-macrophage subsets have been identified in multiple pathological settings ${ }^{21}, 22$, including experimental and human atherosclerotic lesions. ${ }^{23-25}$ Due to the very heterogeneous plaque micro-environment, new plaque-specific macrophage phenotypes, such as Mox and M4 macrophages, were recently discovered. ${ }^{26-28}$

In developed countries, almost all individuals have subclinical atherosclerotic lesions even at young age, and although cancer may affect people of all ages, the risk for the more common varieties of cancer increases with age. Moreover, Mitchel et al. have recently stressed the importance of atherosclerotic disease stage in determining the effect of radiation exposure on the progression of atherosclerosis. ${ }^{29}$ Therefore, we here investigated the effect of local radiotherapy on pre-existing atherosclerotic lesions in the aortic arch of aged $A p o E^{-/}$mice. 


\section{Material and Methods}

\section{Mice and irradiation procedure}

At an age of 28 weeks and an average body weight of 33.2 gram $\pm 1.1, A{ }^{\prime \prime} E^{-}$ mice on a $\mathrm{C} 57 \mathrm{BL} / 6 \mathrm{~J}$ background were randomly allocated to receive irradiation or sham-treatment. The mice were housed in filter-top cages and provided ad libitum with standardized mouse chow containing 3.7\% fat (RM1 (E) SQC, SDS London, UK) and with drinking water. A total of 46 mice were included in the quantitative analysis of atherosclerotic lesions, 22 mice were sacrificed 4 weeks after treatment (10 mice were used as control, 12 mice received irradiation) and 24 mice were sacrificed 12 weeks after treatment (control and irradiated groups contained each 12 mice).

Mice were locally irradiated with a single dose of $14 \mathrm{~Gy}^{(1)}(250-\mathrm{kV}$ X-rays at $12 \mathrm{~mA}$, filtered with $0.6 \mathrm{~mm}$ copper) to the neck region encompassing carotid arteries, aortic arch and base of the heart, as described before ${ }^{10}$, or received sham-treatment ( $0 \mathrm{~Gy}$ ). During irradiation or sham-treatment, mice were immobilized in perspex jigs with the non-target areas shielded with lead.

Experiments were in agreement with the national regulations for animal experiments and the local animal welfare committee approved all experimental protocols.

\section{Tissue preparation}

Immediately after sacrifice the arterial system was perfused with $0.1 \mathrm{mg} / \mathrm{ml}$ sodium-nitroprusside in phosphate-buffered saline (PBS), followed by $1 \%$ paraformaldehyde. The cervical, thoracic and abdominal arterial tree was excised and fixed for 24 hours in 1\% paraformaldehyde before transfer to $70 \%$ ethanol. The aortic arch was embedded in paraffin and $4 \mu \mathrm{m}$ longitudinal, serial sections were cut and numbered sequentially.

\footnotetext{
(1) Assuming an $\alpha / \beta$ ratio of 2-3 Gy for late vascular damage, a single dose of $14 \mathrm{~Gy}$ is approximately equivalent to $48-56$ Gy in 2 Gy fractions, according to the Linear Quadratic formula:

$\mathrm{EQD2}=\mathrm{D}(\mathrm{d}+(\alpha / \beta) / 2+(\alpha / \beta))$

EQD2 = equivalent dose in 2 Gy fractions; $D$ = total dose; $d$ = dose per fraction
} 
Morphometric analysis of plaque

Every fifth section of the aortic arch was stained with hematoxylin and eosin (H\&E) and examined for the presence of atherosclerotic plaques, as described previously ${ }^{10}$. These plaques were categorized as initial lesions (macrophagerich without a thick fibrous cap) or advanced lesions (well-defined necrotic core or thick fibrous cap) based on the criteria by Virmani et al. ${ }^{30}$ The mean number of initial and advanced lesions in the brachiocephalic artery was determined 4 and 12 weeks after 0 Gy or $14 \mathrm{~Gy}$.

Morphometric parameters were analyzed using a microscope coupled to a computerized morphometry system (Leica Qwin V3, Leica, The Netherlands). All measurements were done by one investigator (KG), without prior knowledge of the treatment group. The intra-observer variation was less than $10 \%$. Plaque and necrotic areas (expressed as percentage of individual plaque area) were measured on four selected sections that cover the central part of the brachiocephalic artery lesion (present in $90 \%$ of the mice) and the average of these measurements was determined.

The collagen content, based on a Sirius Red staining, was analyzed on two selected sections that cover the central part of the advanced brachiocephalic artery lesion. The relative collagen content was calculated by dividing the area of collagen by the individual plaque area. The average collagen content was determined per lesion.

Evaluation of thrombotic characteristics of plaques in the aortic arch was performed on one of the central sections and scored semi-quantitatively. Sections were examined for the presence of fibrin deposits (Martius-ScarletBlue Trichrome staining) and erythrocyte- (H\&E staining) or iron (Fe)containing macrophages (Perl's staining), as an indication of previous intraplaque hemorrhage.

\section{Immunohistochemistry}

One central section per brachiocephalic artery lesion was stained with MAC3antibody (1:30, Becton \& Dickinson, USA), cleaved caspase-3-antibody (1:100, Cell Signaling, USA) and CD45-antibody (1:5000, Becton \& Dickinson, USA) to detect macrophages, apoptotic cells and leukocytes, respectively. Results were expressed as number of antibody-positive cells relative to the average plaque area and group means were calculated. Furthermore, a staining with rabbit- 
anti-mouse iNOS (1:20, Abcam, UK) and rabbit-anti-mouse arginase-1 (1:500, kindly provided by Paul van Dijk, department of Anatomy and Embryology, Maastricht University, The Netherlands) was performed to semi-quantitatively score the presence of respectively M1 (pro-inflammatory) and M2 (antiinflammatory) macrophages in the plaque (grading no presence, presence or high presence).

\section{Macrophage culture and irradiation}

Both tibias and femurs were removed from $\mathrm{ApoE}^{-/}$mice. The bone marrow was harvested by flushing the bones with PBS using a $25 \mathrm{G}$ needle. After collecting, the cells were centrifuged for 5 minutes at $4^{\circ} \mathrm{C}, 1100 \mathrm{rpm}$. Cell pellets were resuspended in cell culture medium (RPMI + 25MM HEPES buffer + L-glutamine, with $1 \%$ penicillin/streptavidin and $10 \%$ filtered fetal calf serum), containing $15 \%$ fresh LCM. LCM, a conditioned medium from L929 cells (fibroblast cell line), contains macrophage-colony stimulating factor (M-CSF) and differentiates the bone marrow cells into macrophages attaching to the plate, while other cell types do not survive. After 3 and 6 days at $37^{\circ} \mathrm{C}$, medium was refreshed and on day 7 macrophages were collected from the plate by adding lidocaine dissolved in PBS containing EDTA (0.2\%) for 1-2 minutes at $37^{\circ} \mathrm{C}$. Cell number was counted using a Burker Chamber. Depending on the type of experiment, cells were diluted to the desired concentration to be seeded in culture plates.

To test the effect of irradiation on M1- and M2-macrophage polarization and function, cells were seeded in a 24 (RNA isolation and efferocytosis assay) or 48 well cell-culture plate (apoptosis assay). The following conditions were investigated: $0 \mathrm{~Gy}, 0.5 \mathrm{~Gy}$ (low-dose) and $5 \mathrm{~Gy}$ (high-dose) irradiation of either M0 (unstimulated), M1 (18 hours lipopolysaccharides (LPS) stimulation, 0.01 $\mu \mathrm{g} / \mathrm{ml}$, Sigma), or $\mathrm{M} 2$ (18 hours interleukin (IL)-4 stimulation, $20 \mathrm{ng} / \mathrm{ml}$, Peprotech via Bioconnect) macrophages using X-radiation (Philips MU15F/225, RNL, Maastricht, The Netherlands).

\section{Apoptosis assay}

Macrophages were plated in a 48 well cell-culture cluster plate at a concentration of $1.5 \times 10^{5}$ cells per well, skewed towards a M0, M1 or M2 phenotype, and irradiated as described above. Immediately after irradiation, 
macrophages were labeled with Annexin A5-Alexa fluor (Invitrogen, 1:20 diluted in binding buffer, incubated at $37^{\circ} \mathrm{C}$ for 15 minutes). Bright field and fluorescent photos were taken with a $40 x$ objective ( 5 photos per well) and the number of apoptotic cells was determined by overlaying both photos. Results were expressed as the ratio of fluorescent (apoptotic) to total cells.

\section{Efferocytosis assay}

Macrophages were seeded in a 24 well cell-culture plate $\left(3.5 \times 10^{5}\right.$ cells per well) and labeled with cell tracker Red (Invitrogen, 1:500, 30 min in serum free RPMI medium). Apoptotic macrophages, stained with Calcein-AM (Invitrogen, 1:1000, $60 \mathrm{~min}$ ) and induced by 7-ketocholesterol (7KC, Sigma, 1:500, 24hrs), were added to the labeled macrophages ( $1 \times 10^{6}$ apoptotic cells per well) and incubated for 45 minutes. After incubation, non-bound cells were washed and cells were dissociated from the wells with lidocaine as described above, centrifuged $\left(5 \mathrm{~min}, 4^{\circ} \mathrm{C}, 1100 \mathrm{rpm}\right)$ and resuspended in fluorescence-activated cell sorting (FACS) buffer (0.5\% BSA and $1 \mathrm{mM}$ EDTA in PBS) for analysis using FACS Canto II. Results were expressed as the percentage of double positive events (macrophages containing apoptotic cells).

\section{Gene expression profiling}

Gene expression profiles were determined by quantitative real-time polymerase chain reaction ( $\mathrm{qPCR}$ ) of $5 \times 10^{5}$ cells per well. RNA was isolated according to the manufacturer's protocol (RNA isolation kit of Bioké, Nucleospin ${ }^{\circledR}$ RNA II, Macherey-Nagel, Germany) and stored at $-80^{\circ} \mathrm{C}$. RNA was converted into stable CDNA by reverse transcriptase PCR (RT-PCR) using iSCript $^{\text {TM }}$ CDNA synthesis kit (BIO-RAD, CA) to a desired concentration of 25 $\mathrm{ng} / \mu \mathrm{l}$. cDNA (10 ng) was used for amplification and products were probed with Taqman IQ ${ }^{\text {TM }}$ SYBR Green Super Mix (BIO-RAD, CA). Specific genes of interest (Supplemental Table I on page 111) were analyzed with Biorad CFX manager. An average housekeeping gene expression of $18 \mathrm{~S}$ and cyclophilin was considered as reference value for total RNA expression.

\section{Statistics}

Groups were compared using a non-parametric Mann-Whitney U-test. Data of semi-quantitative assessment of plaque phenotype were compared using 
Fisher's exact test. Group differences were considered statistically significant at $P<0.05$.

\section{Results}

\section{Evaluation of systemic effects}

There was no significant difference in body weight between the irradiated and sham-treated mice at the start of treatment or time of sacrifice. After 12 weeks follow-up the sham-treated mice gained weight, whereas the irradiated mice did not (Supplemental Table II on page 112). No mice had to be prematurely sacrificed due to health problems.

Plaque size and phenotype after in vivo irradiation

Lesions in the brachiocephalic artery were categorized as initial or advanced. Four weeks after sham-treatment, $37.5 \%$ of lesions were classed as initial, while by 12 weeks all lesions had progressed to the advanced stage (Figure 1AB). This shift from initial to advanced plaque phenotype was confirmed by a significant increase in relative collagen content from $20.8 \%$ at 4 weeks to $44.2 \%$ at 12 weeks follow-up ( $P<0.05$, data not shown). Four weeks after $14 \mathrm{~Gy}$ irradiation, $90.9 \%$ of lesions were classified as advanced ( $P<0.001$, Figure 1A), suggesting that irradiation had accelerated the disease progression. On the other hand, irradiation significantly decreased advanced (Figure 1C) and total plaque area (Figure 1D) after 12 weeks follow-up, compared to unirradiated controls. The relative lipid core areas of irradiated and control lesions were not different at 4 and 12 weeks follow-up (means of $26.7 \% \pm 4.0$ and $24 \% \pm 4.5$ at 12 weeks after 0 and 14 Gy respectively, data not shown). 
A

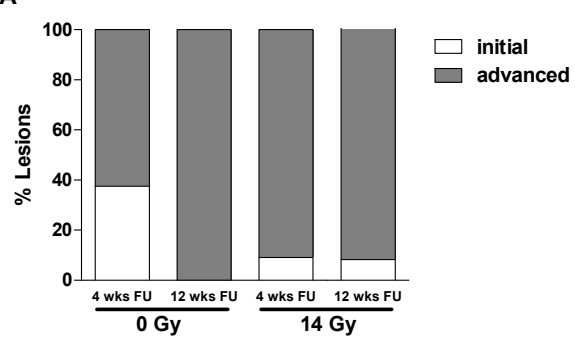

C

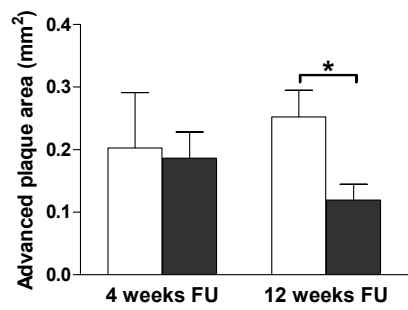

B

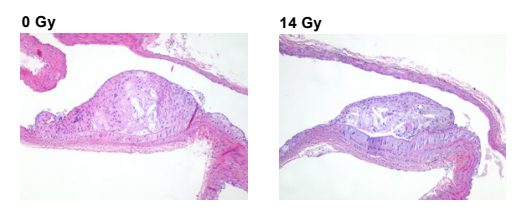

D

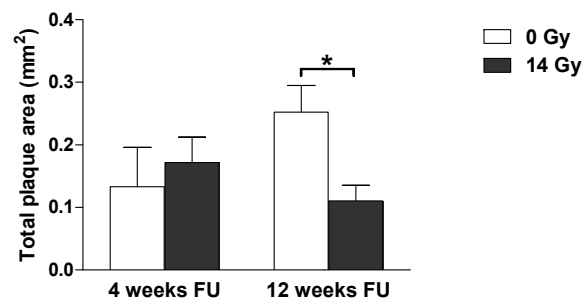

Figure 1. Morphometric analysis of existing lesions in the brachiocephalic artery after 4 and 12 weeks follow-up (FU). (A) Bar graphs showing percentage initial and advanced lesions of total lesions after $0 \mathrm{~Gy}$ and $14 \mathrm{~Gy}$ irradiation. (B) Representative photographs (10 x objective) of H\&E staining of an advanced lesion 12 weeks after 0 and $14 \mathrm{~Gy}$. (C) The mean advanced and (D) total (initial and advanced) plaque areas. Error bars are SEM and * indicates significant differences between irradiated ( $14 \mathrm{~Gy}$ ) and unirradiated ( $0 \mathrm{~Gy}$ ) mice ( $P<0.05$ by Mann-Whitney test).

The number of erythrocyte- or Fe-containing macrophages (indicative of previous hemorrhage) was higher in lesions 12 weeks after irradiation than in control lesions (Supplemental Table III on page 112), without an increase in fibrin deposits.

In unirradiated lesions the macrophage content and number of apoptotic cells decreased with time (Figure 2A-B). In the irradiated lesions, however, macrophage content progressively increased with time and the number of apoptotic cells, characterized histological as macrophage foam cells confirmed by MAC3-immunostaining on adjacent sections (Figure 2C), remained high (Figure 2A-B). At 12 weeks after treatment, both the macrophage and apoptotic cell content of irradiated lesions were significantly higher than control lesions (Figure 2A-B). The increased apoptotic rate in lesions of irradiated mice may have contributed to the observed decrease in advanced plaque area (Figure 1C). There were no significant differences in lesional CD45 $5^{+}$ 
leukocyte content between treatment groups at 4 to 12 weeks follow-up (data not shown).

A

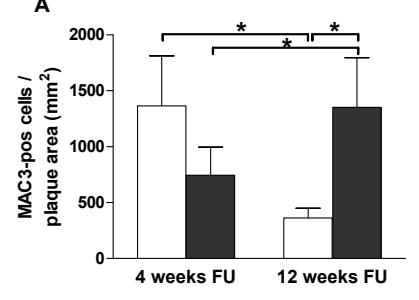

B

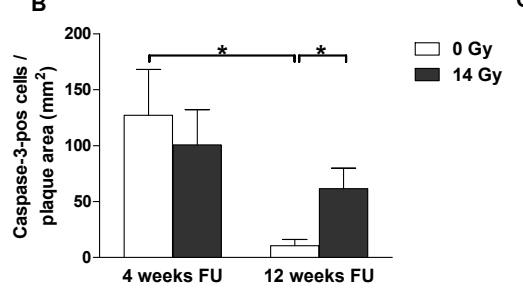

C

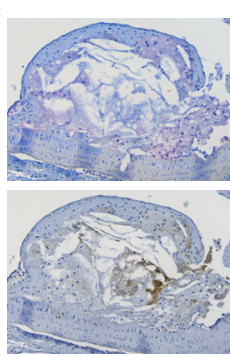

Figure 2. (A) Mean MAC3- and (B) cleaved caspase-3-positive cells relative to total plaque area 4 and 12 weeks after (sham-)irradiation of the brachiocephalic artery. Error bars show SEM. * $P<0.05$ by Mann-Whitney test. (C) Representative photographs ( $20 \times$ objective) of MAC3 (top, red) and cleaved caspase-3 (bottom, brown) immunostaining of an irradiated lesion at 12 weeks follow-up (FU).

\section{Effects of irradiation on macrophages}

Addition of the positive control 7KC resulted in $29.7 \%$ apoptosis in $\mathrm{MO}$ macrophages (Supplemental Figure IA on page 113). After sham-treatment (0 Gy), the unstimulated macrophages (MO) contained $4.6 \%$ apoptotic cells. Stimulation with LPS (M1) or IL-4 (M2) both increased apoptosis $(13.7 \%$ and $12.1 \%$ respectively). Low- and high-dose irradiation induced similar levels of apoptosis in the M0 macrophages (10.9\% and $12.3 \%$, respectively), whereas irradiation did not induce apoptosis in $\mathrm{M} 1$ or $\mathrm{M} 2$ macrophages. Taken together, these data indicate that in vitro macrophage skewing induced a similar level of apoptosis as irradiation, and that irradiation of skewed M1 or M2 macrophages did not further increase apoptosis.

The influence of irradiation on phagocytic capacity was determined in M0 (unstimulated), M1 (LPS stimulated) and M2 (IL-4 stimulated) macrophages. Phagocytic capacity of MO macrophages was not influenced by irradiation (Supplemental Figure IB on page 113). However, high-dose irradiation significantly decreased the ability of $\mathrm{M} 2$ macrophages to take up apoptotic cells (Supplemental Figure IB-C on page 113). The baseline phagocytic capacity of M1 macrophages was lower than M0 macrophages, and was stimulated by low- and high-dose irradiation. 
Macrophage phenotype after irradiation

Irradiated or sham-treated macrophages were stimulated in vitro with either LPS or IL-4 to polarize towards a pro- (M1) or an anti-inflammatory (M2) phenotype. Differential cytokine production is a key feature of polarized macrophages and many specific markers of M1 and M2 macrophages have been described. ${ }^{31}$ As expected, IL-4-primed macrophages showed no expression of the M1-specific marker iNOS (Figure 3A) and LPS-stimulated macrophages showed undetectable expression of the M2-specific marker arginase-1 (Figure 4A). This indicates that macrophages were fully polarized into M1 or M2 macrophages.

Gene expression levels of iNOS, IFN- - , TNF- $\alpha$ and interleukins IL-6, IL-12 $\beta$ and IL-18 were higher after polarization with LPS (Figure 3A-F). The expression of all of these M1-related genes was dose-dependently augmented after irradiation with $0.5 \mathrm{~Gy}$ and $5 \mathrm{~Gy}$ (not significant for iNOS and IFN- $\gamma$ ), compared to unirradiated control macrophages (Figure 3A-F).

Polarization of anti-inflammatory M2 macrophages with IL-4 resulted in specific upregulation of arginase-1, IL-10, insulin-like growth factor 1 (IGF1), chitinase-like lectin (YM1) and scavenger receptors such as mannose receptor (MaRc) and dendritic cell immune receptor (DCIR) (Figure 4A-F). High-dose irradiation ( $5 \mathrm{~Gy}$ ) was seen to further increase expression levels of all of these M2-related genes, while low doses of 0.5 Gy did not (Figure 4A-F).

Considerably more lesions in irradiated mice were enriched in $\mathrm{M} 1$ macrophages at 12 weeks follow-up (9/11 brachiocephalic artery lesions showed high expression of iNOS versus $4 / 11$ for the controls) (Figure 5A). In keeping, M2 macrophages were less prominent in irradiated brachiocephalic artery lesions (8/9 showed no expression of arginase-1 versus $6 / 12$ for the controls). 
A
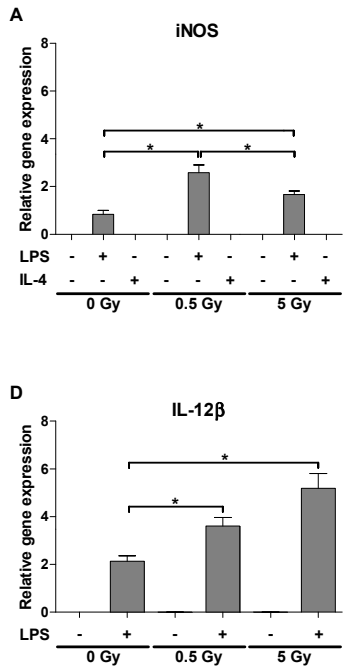

B

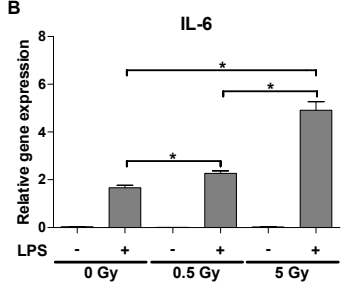

$E$

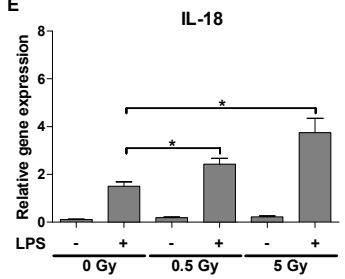

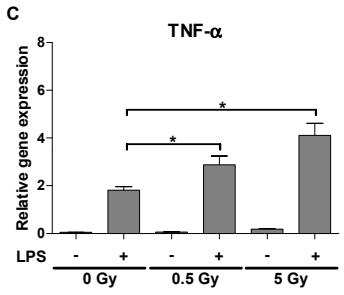

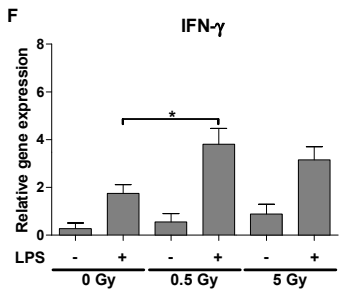

Figure 3. Gene expression levels (relative to housekeeping genes) of specific M1 markers after irradiation and stimulation of in vitro $A p o E^{-/}$bone-marrow derived macrophages ( $n=8$ wells/condition). Error bars are SEM and ${ }^{*}$ indicates significant differences $(P<0.05$ by MannWhitney test).

A

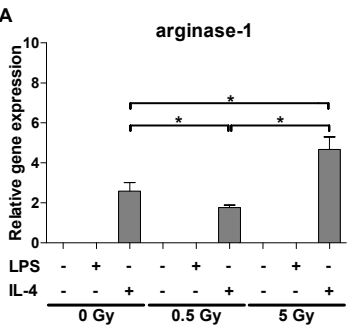

D

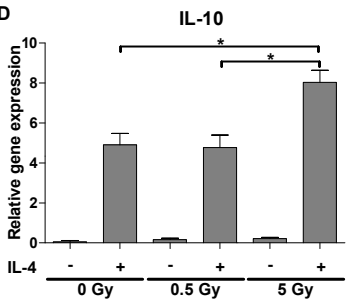

B

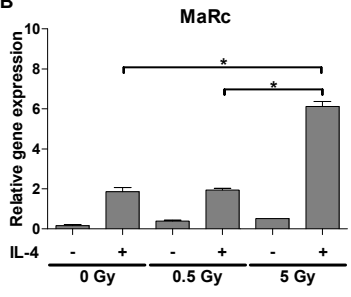

E

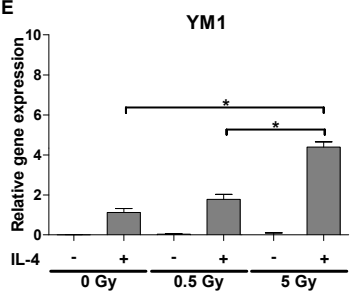

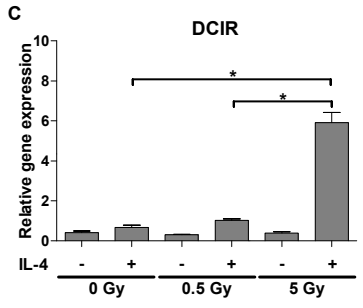

F

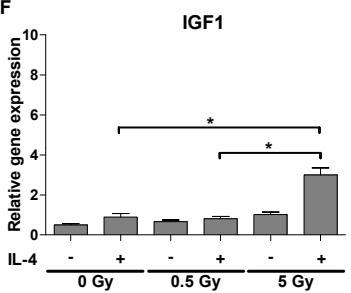

Figure 4. Gene expression levels (relative to housekeeping genes) of specific M2 markers after irradiation and stimulation of in vitro $A p o E^{-/}$bone-marrow derived macrophages ( $\mathrm{n}=8$ wells/condition). Error bars are SEM and $*$ indicates significant differences ( $P<0.05$ by MannWhitney test). 

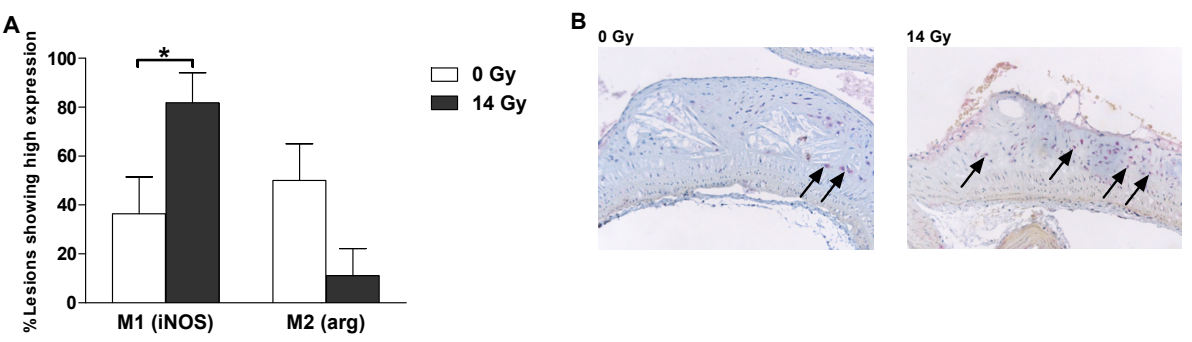

Figure 5. Percentage of brachiocephalic artery lesions showing high expression of $M 1$ or $M 2$ macrophages 12 weeks after 0 or $14 \mathrm{~Gy}$. (A) Percentage of lesions showing high presence of iNOS- or arginase-1- (arg) positive macrophages. (B) Representative photographs (20x objective) of iNOS-immunostaining (red, arrows) of unirradiated and irradiated lesions at 12 weeks followup.

\section{Discussion}

To emulate most closely the clinical situation for elderly cancer patients with a cardiovascular burden receiving radiotherapy, we exposed aged $\mathrm{ApoE}^{-/}$mice with pre-existing atherosclerotic lesions to local thoracic irradiation. We found that irradiation of existing lesions accelerated advanced atherosclerosis development and predisposed to an inflammatory, macrophage-rich plaque phenotype prone to hemorrhage. These findings are consistent with previous studies of plaque development after single dose or fractionated irradiation. ${ }^{9,10,}$ ${ }^{32-34}$ Such a shift in phenotype could render the plaques more vulnerable to rupture, thereby contributing to the higher risk for CVD after radiotherapy. Of note, an association between plaque hemorrhage and macrophage presence has been reported. ${ }^{35}$

Rapid recognition, uptake and degradation of apoptotic macrophages by phagocytes, prevents secondary necrosis and triggers an anti-inflammatory response mediated by IL-10, transforming growth factor $\beta$ (TGF $\beta$ ) and other cytokines. ${ }^{36}$ The process of efferocytosis, one of the main functions of antiinflammatory M2 macrophages ${ }^{20,36}$, is therefore crucial in the resolution of inflammation and plaque stability. ${ }^{37,}{ }^{38}$ There can be many underlying reasons for impaired efferocytosis, including improper presentation of apoptotic ligands, failure to secrete recruitment signals or a defect at the level of the phagocyte itself. In case of mice lacking the engulfment receptor MerTK, a 
defect in macrophage efferocytosis was observed, which resulted in an increase in plaque apoptotic cellular debris, inflammation and necrosis thereby accelerating the progression of atherosclerosis. ${ }^{39,40}$

In advanced atherosclerotic plaques, macrophages outnumber all other phagocytes. ${ }^{41}$ Therefore, a defect in apoptotic cell clearance is most likely attributable to macrophage loss or dysfunction. Our study showed that in vitro irradiation of M2 macrophages reduced its phagocytic function. This could contribute to the increased presence of lesional apoptotic cells, which was not compensated by an increased phagocytic capacity of M1 macrophages as observed after in vitro irradiation. The increased number of apoptotic cells results in a more inflammatory plaque phenotype as new leukocytes are recruited.

One of the hallmarks of macrophages is their ability to maintain plasticity, meaning that alteration of micro-environmental signals could change their phenotype and subsequent function, and shifts the balance between M1 and $M 2$ populations. Such adaptive responses may well be decisive for the course of atherosclerotic plaque development and progression. ${ }^{42}$ Illustratively, Hirata et al. showed a positive correlation between the expression of M1derived pro-inflammatory cytokines and the severity of coronary artery disease. ${ }^{43}$ It was proposed that M2 macrophages predominate in initial lesions, with a switch to M1 macrophages in advanced lesions, due to changes in the cytokine milieu. ${ }^{23,44}$ In vivo radiation exposure of an existing plaque could lead to a chronic hyperinflammatory plaque micro-environment by inducing oxidative damage and cell death ${ }^{45}$, thereby indirectly favoring a switch in macrophage polarization. Indeed, we observed more macrophages with a proinflammatory $\mathrm{M} 1$ phenotype after plaque irradiation. In addition, increased gene expression of specific M1 and M2 markers after macrophage irradiation in vitro suggests a possible direct effect of irradiation on the inflammatory status of plaque macrophages. The radiation-induced imbalance in M1 and M2 macrophages in the plaque can contribute to the accumulation of apoptotic cells, rendering the plaque more unstable. Future studies should investigate how irradiation can directly alter macrophage inflammatory status and function in the plaque, and can augment the polarization-effects of specific stimuli, in order to identify specific targets for early preventive measures in radiation-induced inflammatory atherosclerosis. 
In conclusion, we highlighted the importance of investigating the effect of irradiation on pre-existing atherosclerotic lesions as an underlying pathogenic cause of increased long-term risk for CVD. We show that irradiation results in an increased presence of lesional macrophages, specifically proinflammatory M1 macrophages, and an accumulation of apoptotic cells. Further understanding of the underlying effects of irradiation will help to identify interventional strategies to prevent or ameliorate the accelerated development and progression of radiation-induced atherosclerosis. 


\section{Supplemental data}

Supplemental Table I. Forward and reverse primer sequences of genes tested by qPCR.

Forward primer (5'-3') Reverse primer (5'-3')

\begin{tabular}{|c|c|c|}
\hline \multicolumn{3}{|l|}{ M1-markers } \\
\hline iNOS & CCTGGTACGGGCATTGCT & GCTCATGCGGCCTCCTTT \\
\hline TNF- $\alpha$ & САTСTTCTCAAAATTCGAGTGACAA & TGGGAGTAGACAAGGTACAACCC \\
\hline IFN- $\boldsymbol{\gamma}$ & ATCTGGAGGAACTGGCAAAA & TTCAAGACTTCAAAGAGTCTGAGGTA \\
\hline IL-12及 & CGCAGCAAAGCAAGATGTGT & TGGAGACACCAGCAAAACGA \\
\hline IL-6 & ACAAGTCGGAGGCTTAATTACACAT & TTGCCATTGCACAACTCTTTTC \\
\hline IL-18 & ACAACTTTGGCCGACTTCAC & GGGTTCACTGGCACTTTTGAT \\
\hline \multicolumn{3}{|l|}{ M2-markers } \\
\hline arginase-1 & ATGGAAGAGACCTTCAGCTAC & GCTGTCTTCCCAAGAGTTGGG \\
\hline MaRc & GCAAATGGAGCCGTCTGTGC & CTCGTGGATCTCCGTGACAC \\
\hline DCIR & CCTGGTGATTCTATGCTGTGGT & GTCAGAAGAGAGCCTTGTTCCTTC \\
\hline IL-10 & TGCTCCTAGAGCTGCGGACT & CTTGATTTCTGGGCCATGCT \\
\hline YM1 & TGGCCCACCAGGAAAGTACA & CAGTGGCTCCTTCATTCAGAAA \\
\hline IGF-1 & TTCAGTTCGTGTGTGGACCGAG & TCCACAATGCCTGTCTGAGGTG \\
\hline Cyclophilin & CAAATGCTGGACCAAACACAA & TTCACCTTCCCAAAGACCACAT \\
\hline $18 S$ & GTAACCCGTTGAACCCCATT & CCATCCAATCGGTAGTAGCG \\
\hline
\end{tabular}


Supplemental Table II. Changes in mouse weight in gram (g) between the start of treatment and the time of sacrifice.

\begin{tabular}{|c|c|c|c|}
\hline & Weight $(\mathrm{g})$ at treatment & Weight (g) at sacrifice & $\begin{array}{c}\text { Finale weight } \\
\text { (\% of initial weight) }\end{array}$ \\
\hline \multicolumn{4}{|c|}{4 weeks FU } \\
\hline 0 Gy & $33.1 \pm 0.8$ & $33.0 \pm 0.8$ & $99.7 \pm 1.1$ \\
\hline $14 \mathrm{~Gy}$ & $33.1 \pm 0.8$ & $33.0 \pm 0.7$ & $99.8 \pm 1.0$ \\
\hline \multicolumn{4}{|c|}{12 weeks FU } \\
\hline 0 Gy & $32.7 \pm 2.1$ & $33.9 \pm 0.7$ & $104.6 \pm 2.4$ \\
\hline $14 \mathrm{~Gy}$ & $33.9 \pm 0.7$ & $32.8 \pm 0.5$ & $99.0 \pm 0.9^{*}$ \\
\hline
\end{tabular}

Supplemental Table III. Semi-quantitative assessment of aortic arch lesions containing specific thrombotic characteristics at 4 and 12 weeks follow-up (FU). Due to bad quality of the tissue during staining procedure, 1 and 2 aortic arches could not be analyzed 4 weeks after respectively 14 Gy and 0 Gy.

\begin{tabular}{lcc}
\hline & Ery-/Fe-macrophages & Fibrin deposits \\
\hline 4 weeks FU & & \\
0 Gy & $2 / 8$ & $4 / 8$ \\
14 Gy & $3 / 11$ & $9 / 11$ \\
& & \\
$\mathbf{1 2}$ weeks FU & & \\
0 Gy & $2 / 12$ & $8 / 12$ \\
$\mathbf{1 4}$ Gy & $7 / 12^{*}$ & $6 / 12$ \\
\hline
\end{tabular}

* indicates significant difference between irradiated ( $14 \mathrm{~Gy}$ ) and control ( $0 \mathrm{~Gy}$ ) mice, $P<0.05$ by Fisher's Exact test. 

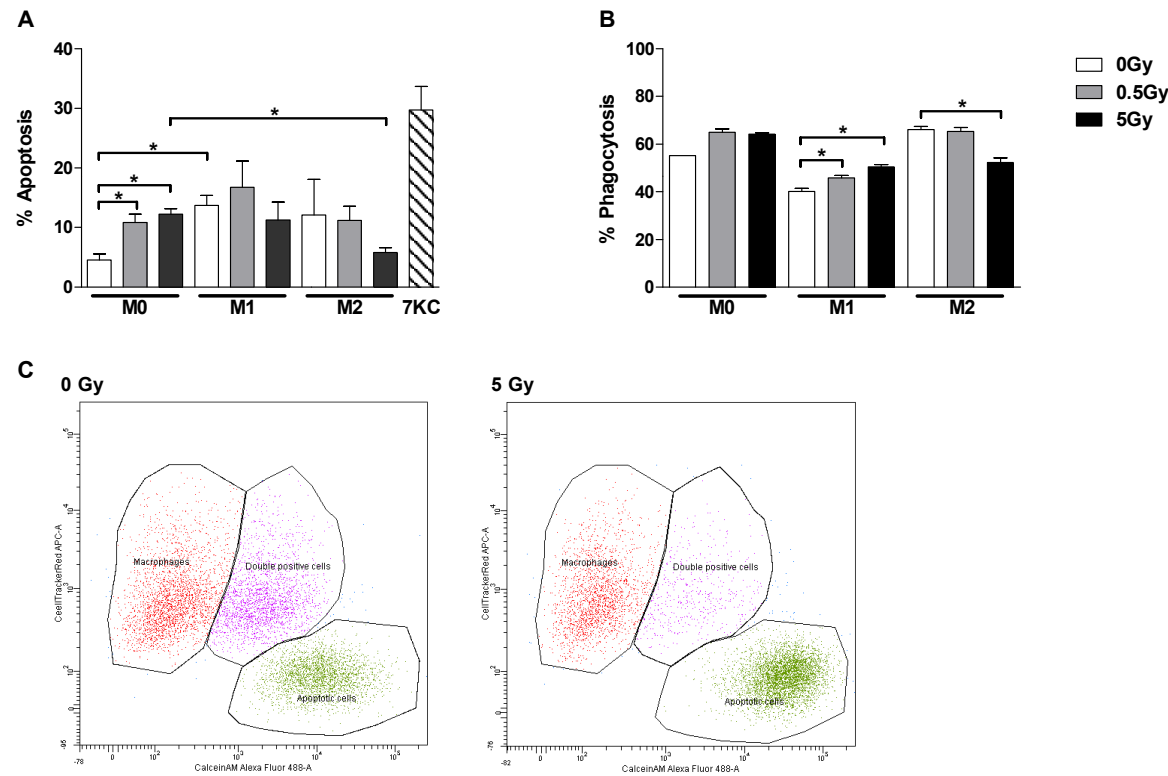

Supplemental Figure I. (A) Percentage of apoptosis of $A p o E^{-/-}$bone-marrow derived macrophages ( $n=5$ wells/condition), with 7-ketocholesterol (7KC) as a control inducer, and (B) percentage uptake of apoptotic macrophages (\% phagocytosis) by unstimulated (M0) and polarized $A p o E^{-1-}$ bone-marrow derived macrophages (M1, M2) after low- and high-dose irradiation ( $\mathrm{n}=5$ wells/condition). Error bars are SEM and ${ }^{*}$ indicates significant differences ( $P<0.05$ by Mann-Whitney test). (C) Representative FACS plots of Cell Tracker Red-labeled M2 macrophages (red), Calcein-AM-labeled apoptotic cells (green) and double positive cells (purple) after 0 and $5 \mathrm{~Gy}$. 


\section{References}

1. Lopez AD, Mathers CD, Ezzati M, Jamison DT, Murray CJ. Global and regional burden of disease and risk factors, 2001: Systematic analysis of population health data. Lancet. 2006;367:1747-1757

2. Sardaro A, Petruzzelli MF, D'Errico MP, Grimaldi L, Pili G, Portaluri M. Radiationinduced cardiac damage in early left breast cancer patients: Risk factors, biological mechanisms, radiobiology, and dosimetric constraints. Radiotherapy and oncology : journal of the European Society for Therapeutic Radiology and Oncology. 2012;103:133-142

3. Andratschke N, Maurer J, Molls M, Trott KR. Late radiation-induced heart disease after radiotherapy. Clinical importance, radiobiological mechanisms and strategies of prevention. Radiotherapy and oncology : journal of the European Society for Therapeutic Radiology and Oncology. 2011;100:160-166

4. McGale P, Darby SC, Hall P, Adolfsson J, Bengtsson NO, Bennet AM, Fornander T, Gigante B, Jensen MB, Peto R, Rahimi K, Taylor CW, Ewertz M. Incidence of heart disease in 35,000 women treated with radiotherapy for breast cancer in denmark and sweden. Radiotherapy and oncology : journal of the European Society for Therapeutic Radiology and Oncology. 2011;100:167-175

5. Darby SC, Cutter DJ, Boerma M, Constine LS, Fajardo LF, Kodama K, Mabuchi K, Marks LB, Mettler FA, Pierce L, Trott KR, Yeh ET, Shore RE. Radiation-related heart disease: Current knowledge and future prospects. International journal of radiation oncology, biology, physics. 2010;76:656-665

6. Adams MJ, Hardenbergh PH, Constine LS, Lipshultz SE. Radiation-associated cardiovascular disease. Critical reviews in oncology/hematology. 2003;45:55-75

7. Aleman BM, van den Belt-Dusebout AW, Klokman WJ, Van't Veer MB, Bartelink H, van Leeuwen FE. Long-term cause-specific mortality of patients treated for hodgkin's disease. Journal of clinical oncology : official journal of the American Society of Clinical Oncology. 2003;21:3431-3439

8. Ross R. Atherosclerosis--an inflammatory disease. The New England journal of medicine. 1999;340:115-126

9. Hoving S, Heeneman S, Gijbels MJ, te Poele JA, Russell NS, Daemen MJ, Stewart FA. Single-dose and fractionated irradiation promote initiation and progression of atherosclerosis and induce an inflammatory plaque phenotype in apoe(-/-) mice. International journal of radiation oncology, biology, physics. 2008;71:848-857

10. Stewart FA, Heeneman S, Te Poele J, Kruse J, Russell NS, Gijbels M, Daemen M. lonizing radiation accelerates the development of atherosclerotic lesions in apoe-/- mice and predisposes to an inflammatory plaque phenotype prone to hemorrhage. The American journal of pathology. 2006;168:649-658

11. Gabriels K, Hoving S, Seemann I, Visser NL, Gijbels MJ, Pol JF, Daemen MJ, Stewart FA, Heeneman S. Local heart irradiation of apoe(-/-) mice induces microvascular and endocardial damage and accelerates coronary atherosclerosis. Radiotherapy and oncology : journal of the European Society for Therapeutic Radiology and Oncology. 2012;105:358-364

12. Stoneman V, Braganza D, Figg N, Mercer J, Lang R, Goddard M, Bennett M. Monocyte/macrophage suppression in $\mathrm{cd} 11 \mathrm{~b}$ diphtheria toxin receptor transgenic mice differentially affects atherogenesis and established plaques. Circulation research. 2007;100:884-893

13. Moore KJ, Tabas I. Macrophages in the pathogenesis of atherosclerosis. Cell. 2011;145:341-355 
14. Libby P. Inflammation in atherosclerosis. Nature. 2002;420:868-874

15. Mosser DM, Edwards JP. Exploring the full spectrum of macrophage activation. Nature reviews. Immunology. 2008;8:958-969

16. Gordon S. Alternative activation of macrophages. Nature reviews. Immunology. 2003;3:23-35

17. Classen A, Lloberas J, Celada A. Macrophage activation: Classical versus alternative. Methods Mol Biol. 2009;531:29-43

18. Martinez FO, Helming L, Gordon S. Alternative activation of macrophages: An immunologic functional perspective. Annual review of immunology. 2009;27:451-483

19. Mosser DM, Zhang X. Activation of murine macrophages. Current protocols in immunology / edited by John E. Coligan ... [et al.]. 2008;Chapter 14:Unit 1412

20. Martinez FO, Sica A, Mantovani A, Locati M. Macrophage activation and polarization. Frontiers in bioscience : a journal and virtual library. 2008;13:453-461

21. Odegaard JI, Ricardo-Gonzalez RR, Red Eagle A, Vats D, Morel CR, Goforth MH, Subramanian V, Mukundan L, Ferrante AW, Chawla A. Alternative m2 activation of kupffer cells by ppardelta ameliorates obesity-induced insulin resistance. Cell metabolism. 2008;7:496-507

22. Mantovani A, Sozzani S, Locati M, Allavena P, Sica A. Macrophage polarization: Tumorassociated macrophages as a paradigm for polarized $\mathrm{m} 2$ mononuclear phagocytes. Trends in immunology. 2002;23:549-555

23. Khallou-Laschet J, Varthaman A, Fornasa G, Compain C, Gaston AT, Clement M, Dussiot M, Levillain O, Graff-Dubois S, Nicoletti A, Caligiuri G. Macrophage plasticity in experimental atherosclerosis. PloS one. 2010;5:e8852

24. Waldo SW, Li Y, Buono C, Zhao B, Billings EM, Chang J, Kruth HS. Heterogeneity of human macrophages in culture and in atherosclerotic plaques. The American journal of pathology. 2008;172:1112-1126

25. Bouhlel MA, Derudas B, Rigamonti E, Dievart R, Brozek J, Haulon S, Zawadzki C, Jude B, Torpier G, Marx N, Staels B, Chinetti-Gbaguidi G. Ppargamma activation primes human monocytes into alternative $\mathrm{m} 2$ macrophages with anti-inflammatory properties. Cell metabolism. 2007;6:137-143

26. Kadl A, Meher AK, Sharma PR, Lee MY, Doran AC, Johnstone SR, Elliott MR, Gruber F, Han J, Chen W, Kensler T, Ravichandran KS, Isakson BE, Wamhoff BR, Leitinger N. Identification of a novel macrophage phenotype that develops in response to atherogenic phospholipids via nrf2. Circulation research. 2010;107:737-746

27. Gleissner CA, Shaked I, Erbel C, Bockler D, Katus HA, Ley K. Cxcl4 downregulates the atheroprotective hemoglobin receptor cd163 in human macrophages. Circulation research. 2010;106:203-211

28. Boyle JJ, Harrington HA, Piper E, Elderfield K, Stark J, Landis RC, Haskard DO. Coronary intraplaque hemorrhage evokes a novel atheroprotective macrophage phenotype. The American journal of pathology. 2009;174:1097-1108

29. Mitchel RE, Hasu M, Bugden M, Wyatt $H$, Little MP, Gola A, Hildebrandt G, Priest ND, Whitman SC. Low-dose radiation exposure and atherosclerosis in apoe(-)/(-) mice. Radiation research. 2011;175:665-676

30. Virmani R, Kolodgie FD, Burke AP, Farb A, Schwartz SM. Lessons from sudden coronary death: A comprehensive morphological classification scheme for atherosclerotic lesions. Arteriosclerosis, thrombosis, and vascular biology. 2000;20:1262-1275

31. Lopez-Castejon G, Baroja-Mazo A, Pelegrin P. Novel macrophage polarization model: From gene expression to identification of new anti-inflammatory molecules. Cellular and molecular life sciences : CMLS. 2011;68:3095-3107 
32. Yu T, Parks BW, Yu S, Srivastava R, Gupta K, Wu X, Khaled S, Chang PY, Kabarowski JH, Kucik DF. Iron-ion radiation accelerates atherosclerosis in apolipoprotein e-deficient mice. Radiation research. 2011;175:766-773

33. Pakala R, Leborgne L, Cheneau E, Chan RC, Yazdi H, Fournadjiev J, Weber D, Hellinga D, Kolodgie F, Virmani R, Waksman R. Radiation-induced atherosclerotic plaque progression in a hypercholesterolemic rabbit: A prospective vulnerable plaque model? Cardiovascular radiation medicine. 2003;4:146-151

34. Schiller NK, Kubo N, Boisvert WA, Curtiss LK. Effect of gamma-irradiation and bone marrow transplantation on atherosclerosis in Idl receptor-deficient mice. Arteriosclerosis, thrombosis, and vascular biology. 2001;21:1674-1680

35. Kolodgie FD, Gold HK, Burke AP, Fowler DR, Kruth HS, Weber DK, Farb A, Guerrero L, Hayase M, Kutys R, Narula J, Finn AV, Virmani R. Intraplaque hemorrhage and progression of coronary atheroma. The New England journal of medicine. 2003;349:2316-2325

36. Tabas I. Macrophage death and defective inflammation resolution in atherosclerosis. Nature reviews. Immunology. 2010;10:36-46

37. Van Vre EA, Ait-Oufella H, Tedgui A, Mallat Z. Apoptotic cell death and efferocytosis in atherosclerosis. Arteriosclerosis, thrombosis, and vascular biology. 2012;32:887-893

38. Schrijvers DM, De Meyer GR, Kockx MM, Herman AG, Martinet W. Phagocytosis of apoptotic cells by macrophages is impaired in atherosclerosis. Arteriosclerosis, thrombosis, and vascular biology. 2005;25:1256-1261

39. Thorp E, Cui D, Schrijvers DM, Kuriakose G, Tabas I. Mertk receptor mutation reduces efferocytosis efficiency and promotes apoptotic cell accumulation and plaque necrosis in atherosclerotic lesions of apoe-/- mice. Arteriosclerosis, thrombosis, and vascular biology. 2008;28:1421-1428

40. Ait-Oufella $H$, Pouresmail V, Simon T, Blanc-Brude O, Kinugawa K, Merval R, Offenstadt G, Leseche G, Cohen PL, Tedgui A, Mallat Z. Defective mer receptor tyrosine kinase signaling in bone marrow cells promotes apoptotic cell accumulation and accelerates atherosclerosis. Arteriosclerosis, thrombosis, and vascular biology. 2008;28:1429-1431

41. Thorp E, Subramanian M, Tabas I. The role of macrophages and dendritic cells in the clearance of apoptotic cells in advanced atherosclerosis. European journal of immunology. 2011;41:2515-2518

42. Mantovani A, Garlanda C, Locati M. Macrophage diversity and polarization in atherosclerosis: A question of balance. Arteriosclerosis, thrombosis, and vascular biology. 2009;29:1419-1423

43. Hirata $Y$, Tabata $M$, Kurobe $H$, Motoki T, Akaike M, Nishio $C$, Higashida M, Mikasa $H$, Nakaya Y, Takanashi S, Igarashi T, Kitagawa T, Sata M. Coronary atherosclerosis is associated with macrophage polarization in epicardial adipose tissue. Journal of the American College of Cardiology. 2011;58:248-255

44. Feig JE, Parathath S, Rong JX, Mick SL, Vengrenyuk Y, Grauer L, Young SG, Fisher EA. Reversal of hyperlipidemia with a genetic switch favorably affects the content and inflammatory state of macrophages in atherosclerotic plaques. Circulation. 2011;123:989-998

45. Fei P, El-Deiry WS. P53 and radiation responses. Oncogene. 2003;22:5774-5783 




\section{chapter five}

\section{Irradiation induced modest changes in}

murine cardiac function despite progressive structural damage to the myocardium and microvasculature

Karen Gabriels*, Ingar Seemann*, Nils L. Visser, Saske Hoving, Johannes A. te Poele, Jeffrey F. Pol, Marion J. Gijbels, Ben J. Janssen, Fijs W. van Leeuwen, Mat.J. Daemen, Sylvia Heeneman", Fiona A. Stewart*

*Authors contributed equally (performing experiments and analyses) "Authors contributed equally. (designing and supervision of the study)

Radiotherapy and Oncology 2012;103(2):143-50 


\section{Abstract}

Background: Radiotherapy of thoracic and chest wall tumors increases the long-term risk of cardiotoxicity, but the underlying mechanisms are unclear.

Methods: Single doses of 2, 8 or $16 \mathrm{~Gy}$ were delivered to the hearts of mice and damage was evaluated at 20, 40 and 60 weeks, relative to age-matched controls. Single photon emission computed tomography (SPECT/CT) and ultrasound were used to measure cardiac geometry and function, which was related to histo-morphology and microvascular damage.

Results: Gated SPECT/CT and ultrasound demonstrated decreases in end diastolic and systolic volumes, while the ejection fraction was increased at 20 and 40 weeks after 2, 8 and $16 \mathrm{~Gy}$. Cardiac blood volume was decreased at 20 and 60 weeks after irradiation. Histological examination revealed inflammatory changes at 20 and 40 weeks after 8 and 16 Gy. Microvascular density in the left ventricle was decreased at 40 and 60 weeks after 8 and $16 \mathrm{~Gy}$, with functional damage to remaining microvasculature manifest as decreased alkaline phosphatase (2, 8 and $16 \mathrm{~Gy})$, increased von Willebrand Factor and albumin leakage from vessels ( 8 and $16 \mathrm{~Gy}$ ), and amyloidosis ( $16 \mathrm{~Gy}$ ). $16 \mathrm{~Gy}$ lead to sudden death between 30 and 40 weeks in $38 \%$ of mice.

Conclusions: Irradiation with 2 and 8 Gy induced modest changes in murine cardiac function within 20 weeks but this did not deteriorate further, despite progressive structural and microvascular damage. This indicates that heart function can compensate for significant structural damage, although higher doses, eventually lead to sudden death. 


\section{Introduction}

Radiation-induced heart disease (RIHD) can be a severe late side effect in cancer patients irradiated to their thorax. ${ }^{1}$ This has relevance for long-term survivors of cancer. ${ }^{2}$ Cancers with a good long-term prognosis that are treated with thoracic irradiation include childhood cancers, breast cancer and Hodgkin's lymphoma. RIHD was first described in the 1960s, after mantle field radiotherapy for Hodgkin's lymphoma. ${ }^{3}$ Since then treatment options and techniques, especially the development of 3D conformal radiation techniques, have improved and the relative 5 -year survival rates for childhood cancer, including Hodgkin's lymphoma, have increased from 30\% in 1960 to $79 \%$ in 2010. ${ }^{4}$ However, longer survival in Hodgkin's lymphoma patients is associated with increased risks (relative to age-matched unirradiated populations) of late cardiac morbidity and mortality; from $2 \%$ after 5 years to $23 \%$ after 20 years. ${ }^{5}$ Epidemiological studies also demonstrate increased risks for cardiac mortality and morbidity for breast cancer patients that received radiotherapy. ${ }^{2,} 6$ Although the relative risk is lower than for Hodgkin's lymphoma patients, the large number of women irradiated for breast cancer makes this a significant health problem. For both patient groups, the risk of RIHD becomes significant 10 years after treatment and increases with time. ${ }^{6,7}$

RIHD includes a wide spectrum of cardiac pathologies, such as pericarditis, cardiomyopathy, valvular disorders, myocardial fibrosis, coronary artery disease, conduction abnormalities, and sudden death. ${ }^{8-10}$ In the early stages, before the onset of functional impairment, some experimental studies have shown evidence of inflammation in the myocardium, endothelial cell damage and decreased myocardial capillary density. ${ }^{11-13}$ Regional cardiac perfusion defects have also been identified in non-symptomatic breast cancer patients from 6 months after radiotherapy. ${ }^{14,}{ }^{15}$ This suggests that early microvascular damage may precede severe cardiac functional impairment.

The risk of RIHD is now well recognized but the underlying mechanisms of its initiation and progression, and the roles played by microvascular damage, fibrosis and atherosclerosis remain unclear. To shed light on the dose dependence of the severity and rate of progression of cardiovascular damage, mouse hearts were irradiated with doses of 2, 8 or $16 \mathrm{~Gy}$ and structural and functional changes were monitored after 20, 40 and 60 weeks. This is the first 
study that characterizes in detail both the functional and structural cardiac damages after local heart irradiation in mice.

\section{Material and methods}

\section{Mice and irradiation procedure}

Male C57BL/6J mice aged 8-12 weeks (from Charles River Laboratories, France) were randomly allocated to different treatment groups and housed in a temperature-controlled room with $12 \mathrm{~h}$ light-dark cycle. Standard mouse chow and water were provided ad libitum. During irradiation or sham-treatment ( 0 Gy) unanaesthetized mice were held in a prone position, in restraining jigs with the thorax fixed using adjustable hinges. Single doses of 2, 8 or $16 \mathrm{~Gy}$ were given to the heart using $250 \mathrm{kV} \mathrm{X}$-rays, operating at $12 \mathrm{~mA}$ and filtered with 0.6 $\mathrm{mm}$ of copper. The dose rate was $0.94 \mathrm{~Gy} / \mathrm{min}$. The field size $(10.6 \times 15.0 \mathrm{~mm})$ and the position was determined in pilot studies using soft X-rays $(25 \mathrm{kV}, 85$ $\mathrm{mA}$ ) to visualize the hearts of mice of the same sex and weight. In order to ensure that the whole heart was irradiated in all mice, up to $30 \%$ of the lung volume was included in the field. The rest of the body was shielded with a 3 $\mathrm{mm}$ thick lead plate.

Separate cohorts of animals were irradiated for functional imaging and collecting of hearts for analyses at 20, 40 and 60 weeks after irradiation. Each dose and time point typically comprised 10-15 mice ( $n=165$ in total). Agematched controls (sham-irradiated with $0 \mathrm{~Gy}$ ) were always included and these provide the appropriate comparison for irradiated groups at that time point.

Experiments were in agreement with the Dutch law on animal experiments and welfare, and in line with the international Guide for the Care and Use of Laboratory Animals (Eighth edition).

\section{SPECT/CT}

Single photon emission computed tomography (SPECT) acquisitions were made with the dedicated small-animal NanoSPECT/CT (Bioscan Europe, Ltd., Paris, France). Animals were anesthetized with Hypnorm (Fentanyl 0.26 $\mathrm{mg} / \mathrm{kg} /$ Fluanisone $8.33 \mathrm{mg} / \mathrm{kg}$, VetaPharma, Ltd., Leeds, UK) and Dormicum (Midazolam, $4.17 \mathrm{mg} / \mathrm{kg}$, Roche, Woerden, The Netherlands) via 
intraperitoneal (i.p.) injection (1:2:1 Hypnorm: $\mathrm{H}_{2} \mathrm{O}$ :Dormicum; $120 \mu \mathrm{l} / \mathrm{mouse}$ ). They were then placed on the animal bed in the prone position and scanned in the tail-first direction. Human Serum Albumin (HSA) (Vasculosis, IBA Molecular, Gif-sur-Yvette, France) was labeled with $1-1.5 \mathrm{ml}{ }^{99 \mathrm{~m}} \mathrm{Tc}$-pertechnetate. The radiotracer $(150 \mu \mathrm{l})$ was injected intravenously (i.v.), at a total activity of about $50 \mathrm{MBq}$ per mouse. X-ray topogram and SPECT acquisition were initiated directly after tracer administration. A total body scan was used to calculate the ratio between the total radioactivity $(\mathrm{MBq})$ in the mouse and in the heart, and hence to calculate the blood volume of the heart chambers.

\section{Gated SPECT/CT}

Three-lead electrodes (3M red Dot 2282E, 3M, St. Paul, USA) were attached to both hind paws and right front paw of the mouse and connected to the integrated electrocardiography (ECG) monitor to measure heart rate (HR). ECG-gated data were recorded in 8 time-bins per cardiac cycle. The tracer tetrofosmin (Myoview, GE-healthcare, Hoevelaken, The Netherlands) was labeled with ${ }^{99 \mathrm{~m}} \mathrm{Tc}$-pertechnetate according to the manufacturer's protocol. The radiotracer $(150 \mu \mathrm{l})$ was injected i.v. with a total activity of about $65 \mathrm{MBq}$ per mouse. Acquisitions were started $1 \mathrm{~h}$ after injection of the tracer. Once a stable HR was established, a short X-ray topogram was made to set the field of view (FOV) and to focus on the thorax to reduce scan time. After the FOV was set, gated SPECT acquisition was started using a quadruple-head gamma camera high precision gantry, equipped with 4 pyramid collimators and 9 pinhole apertures (diameter $1.2 \mathrm{~mm}$ ). The axial FOV was $16 \mathrm{~mm}$. A $20 \%$ window centered on the $140 \mathrm{keV}$ photoelectric peak of ${ }^{99 \mathrm{~m}} \mathrm{Tc}$ was used to acquire 20 projections with uniform angular sampling over a $360^{\circ}$ radius into a $128 \times 128$ matrix. ECG-gated data were recorded in 8 time-bins per cardiac cycle, with an accepted frame time of $180 \mathrm{~s}$. HiSPECT NG software (InVivoScope, Bioscan) was used to perform iterative reconstruction into 3D datasets. Quantitative analysis of the reconstructed datasets was performed on a clinical e.soft (syngo-based) workstation (Siemens Medical Solutions, Siemens AG, Erlangen, Germany), using algorithms to automatically reconstruct a count based 3D model of the dimensions of the left ventricular (LV) end diastolic and systolic volumes (EDV, ESV), as well as the thickness of 
the LV wall in diastole and systole. The ejection fraction (EF) was calculated based on the difference between EDV and ESV divided by EDV.

\section{D-Ultrasound}

Mice were lightly sedated with $2 \%$ isoflurane (Forane, Abbott, Hoofddorp, The Netherlands). Echocardiography images were acquired using a Vevo 770 system (VisualSonics, Toronto, Canada). Images were obtained using a $30 \mathrm{MHz}$ transducer with a focal depth range of $13 \mathrm{~mm}$. Acquisitions were made in Bmode in the long-axis view as well as in the short view, at the papillary muscle level, at a frame rate of about $90 \mathrm{MHz}$. Measurements of LV dimensions were obtained by visual determination in three respective cardiac cycles in long-axis mode. Calculations were based on the measurement of LV length and LV surface area during diastole and systole and the EF was calculated as described above.

\section{Tissue preparation}

On termination of the experiment, the heart was perfused via the aortic arch (retro-grade), under lethal sodium pentobarbital anesthesia (18 mg i.p. per mouse), with PBS (frozen sections) or PBS followed by $1 \%$ paraformaldehyde (paraffin sections). The heart was then quickly excised before freezing on dry ice or immersion in $1 \%$ paraformaldehyde.

\section{Histology}

Cross-sections were cut at the level of the mid-horizontal plane of the heart from fixed paraffin-embedded tissues $(3 \mu \mathrm{m})$ or frozen tissues $(7 \mu \mathrm{m})$.

\section{Paraffin sections}

Transverse sections were stained with hematoxylin and eosin (H\&E) to measure the epicardial and myocardial thickness. To determine the extent of inflammation, sections were immuno-labeled with anti-CD45 antibody (1:5000, Becton\&Dickinson, Franklin lakes, USA). Perls' staining was performed to investigate the presence of iron-containing macrophages, indicative of previous hemorrhage. Based on a Sirius red staining, interstitial collagen was determined in the subendocardium and myocardium of the LV. Double staining for laminin (1:600) and collagen IV (1:2000, both kindly provided by Dr. J 
Cleutjens, Maastricht University, The Netherlands) was used to measure the cross-sectional area of cardiomyocytes. To investigate vascular leakage, paraffin sections were stained for albumin (1:2500, Abcam, Cambridge, USA) and myocardial deposition was determined. A Congo red staining was used to detect amyloid deposits in the myocardium. Within one time group all sections were processed identically, at the same time with precisely the same incubation times for the primary and secondary antibody and diaminobenzidine (DAB) solution (Sigma, Zwijndrecht, The Netherlands). Therefore, all differences between the treatments are ultimately due to DAB identification of the relevant protein.

Photographs of the LV wall (excluding the septum) were taken using a $5 x$ objective (Leica DFC320) and 12 measurements per heart were performed to measure the epicardial and myocardial thickness. The number of CD45-positive cells per section was counted separately in the epicard and myocard to determine the extent of inflammation. Perls' stained sections were examined for evidence of iron-containing macrophages and this was recorded as positive or negative for each section. Interstitial collagen was quantified in five randomly selected areas of the subendocardium and myocardium of the LV (40x objective) and results are expressed as percentage tissue positive for Sirius red relative to myocardial area. Photographs of laminin and collagen IV stained sections were taken using a 20x objective and approximately 200 subendocardial myocytes were measured per heart. Cardiac amyloidosis was diagnosed by the apple-green birefringence of extracellular deposited amyloid fibrils, when stained with Congo red dye and viewed under polarized light. Morphometric parameters were analyzed using a computerized morphometry system (Leica Qwin V3, Leica, Rijswijk, The Netherlands).

\section{Frozen sections}

An anti-CD31 antibody (1:50, Becton\&Dickinson) was used to visualize cardiac vasculature of the central part of the heart. To quantify the percentage of perfused microvessels, FITC-lectin (Fluorescein labeled Lycopersicon Esculentum (Tomato) Lectin (LEL, TL), Vector, Burlingame, USA) (100 $\mu \mathrm{l}$ ) was injected i.v. $5 \mathrm{~min}$ before a lethal injection of sodium pentobarbital. Frozen sections were then stained for CD31 (1:50, Becton\&Dickinson) using a fluorescent secondary antibody labeled with Alexa Fluor 594 (Invitrogen, 
Breda, The Netherlands). To visualize tissue hypoxia, mice were injected i.v. with $10 \mathrm{nM}$ of the hypoxic cell marker 2-nitroimidazole agent EF5 (a kind gift from Dr. C Koch, Department of Radiation Oncology, University of Pennsylvania, USA) $2 \mathrm{~h}$ prior to humane killing, and hearts were stained according to published protocols (www.hypoxia-imaging.org). To check the immunohistochemical procedure, tumor tissue was included as positive hypoxic control; this showed significant areas of EF5 positivity.

To determine functional changes in the microvasculature a histochemical staining with Naphtol AS-MX/DMF and fast Blue BB salt was performed to detect endothelial cell alkaline phosphatase. Sections were also reacted with antibodies against von Willebrand Factor (vWF) (1:4000, Abcam) or thrombomodulin (TM) (1:200, American Diagnostica, Stamford, USA), as markers of thrombotic changes, and vascular cell adhesion molecule 1 (VCAM1) (1:200, Becton\&Dickinson), as a marker for vascular inflammation. Within one time group all sections were processed identically, at the same time with precisely the same incubation times for the primary and secondary antibody and DAB solution.

For quantification of microvessels, five random fields (40x objective) from transverse sections of the subendocardium were photographed with a CCD 2-Color Microscope system, including a Zeiss AxioCam color camera (Axiocam HRc, Zeiss, Göttingen, Germany) and a computerized morphometry system (Leica Qwin V3) was used to quantify the microvascular density (MVD). Vessels beneath a size of 1.5 or above $200 \mu \mathrm{m}^{2}$ were automatically excluded from the measurements. Photographs of CD31/FITC-lectin were taken with a confocal microscope (Leica) and analyzed using Image J computer analysis program, to determine the percentage of microvessels that were perfused. Photographs of whole sections stained for ALP, vWF and TM were taken with an Aperio scanner (Scanscope-XT, Aperio technologies, Vista, USA) using 40x objective. Analyses of the percentage myocardium, excluding endocardium, positive for each marker were done with a computerized morphometry system (Leica Qwin V3). VCAM-1-stained sections were semi-quantitatively analyzed (without knowledge of treatment group) according to the criteria: no, mild or strong expression. 


\section{Statistics}

Data are expressed as mean \pm SEM. Irradiated and control groups were compared using non-parametric Mann-Whitney U-tests or Fisher's exact test (Table 2, Supplemental Table 1 and Figure 5). Group differences were considered statistically significant at $p<0.05$.

\section{Results}

\section{Mouse survival and weight}

There were very few unscheduled deaths after 2 and 8 Gy cardiac irradiation, although heart/body weight ratios of irradiated mice were $12-13 \%$ lower than in age-matched controls at 40 weeks and body weights were reduced by $6-13 \%$ at 60 weeks (Table 1). After $16 \mathrm{~Gy}, 38 \%$ of mice died or had to be humanely killed between 30 and 40 weeks. Because of these unscheduled deaths, all remaining animals in the 16 Gy group were killed at 40 weeks.

Table 1. Body and organ weights of mice at sacrifice.

\begin{tabular}{|c|c|c|c|c|}
\hline Treatment & Body weight ( $\mathrm{g}$ ) & Heart weight $(\mathrm{g})$ & Lung weight (g) & Heart/body weight (g) \\
\hline \multicolumn{5}{|l|}{20 Weeks } \\
\hline & $30.6 \pm 0.7$ & ND & ND & ND \\
\hline $2 \mathrm{~Gy}$ & $32.4 \pm 0.4$ & $0.21 \pm 0.007$ & ND & $6.4 \pm 0.2$ \\
\hline $8 \mathrm{~Gy}$ & $31.9 \pm 0.7$ & $0.19 \pm 0.005$ & ND & $5.9 \pm 0.2$ \\
\hline $16 \mathrm{~Gy}$ & $29.4 \pm 0.6$ & ND & $\mathrm{ND}$ & ND \\
\hline \multicolumn{5}{|l|}{40 Weeks } \\
\hline $0 \mathrm{~Gy}$ & $32.8 \pm 0.6$ & $0.19 \pm 0.005$ & $0.18 \pm 0.003$ & $6.0 \pm 0.1$ \\
\hline $2 \mathrm{~Gy}$ & $35.2^{-} \pm 0.4$ & $0.18 \pm 0.005$ & $0.17^{7} \pm 0.003$ & $5.2 \pm 0.1$ \\
\hline $8 \mathrm{~Gy}$ & $34.0 \pm 0.5$ & $0.18 \pm 0.005$ & $0.17^{7} \pm 0.002$ & $5.3^{-} \pm 0.1$ \\
\hline $16 \mathrm{~Gy}$ & $32.7 \pm 0.5$ & $0.18^{\circ} \pm 0.004$ & $0.19 \pm 0.005$ & $5.4 \pm 0.1$ \\
\hline \multicolumn{5}{|l|}{60 Weeks } \\
\hline & $38.9 \pm 0.7$ & $0.20 \pm 0.007$ & $0.18 \pm 0.005$ & $5.2 \pm 0.2$ \\
\hline $2 G y$ & $36.7^{\circ} \pm 0.8$ & $0.21 \pm 0.006$ & $0.19 \pm 0.006$ & $5.8^{\prime} \pm 0.2$ \\
\hline 8 Gy & $34.0^{\circ} \pm 0.8$ & $0.20 \pm 0.007$ & $0.19 \pm 0.007$ & $5.9 \pm 0.3$ \\
\hline 16 Gy & ND & ND & ND & \\
\hline
\end{tabular}

* Indicates significant differences between irradiated and age-matched control groups $(p<0.05$; Mann-Whitney U-test). ND = not determined.

\section{Non-invasive cardiac imaging}

SPECT/CT and ultrasound were used to examine whether irradiation influenced cardiac function; these imaging experiments were performed in separate groups of mice. Static SPECT/CT images $\left({ }^{99 \mathrm{~m}} \mathrm{Tc}-\mathrm{HSA}\right)$ indicated a significant reduction (18-25\%) in total cardiac blood volume at 20 weeks after 2, 8 and 16 Gy compared to age-matched controls. There was no further reduction in mean cardiac blood volume for remaining mice tested at 40 weeks and no significant differences were observed between irradiated and control groups at 
this time. By 60 weeks, cardiac blood volumes were again significantly lower after 2 and $8 \mathrm{~Gy}$ than in control animals (21-36\%) (Figure 1A).

Gated SPECT/CT images ( $\left.{ }^{99 \mathrm{~m}} \mathrm{Tc}-M y o v i e w\right)$ showed radiation-induced decreases in EDV (10-25\%) and ESV (16-39\%) and increases in EF (6-20\%) at 20 weeks after 2, 8 and 16 Gy (Figure 1B). At 40 weeks, EDV and ESV were still similarly decreased, concomitant with a significant increase in $\mathrm{EF}(20 \%)$ after 8 Gy (Figure 1B). ${ }^{99 m}$ TC-Myoview gated SPECT/CT scans also showed increases in both anterior and posterior wall thickening (systole versus diastole) at 20 weeks after $16 \mathrm{~Gy}$ and in the posterior wall at 40 weeks after $8 \mathrm{~Gy}$ (Figure 2).

Ultrasound measurements showed similar decreases in EDV (20\%) and ESV (33\%) to those measured by gated SPECT, and an increase in EF (28\%) at 20 weeks after 16 Gy. However, at 40 weeks irradiated and control groups were not significantly different when measured by ultrasound (Supplemental Figure I on page 138). 
A $\quad 99 \mathrm{~m}$ Tc-HSA Blood volume

B ${ }^{99 m}$ Tc-Myoview
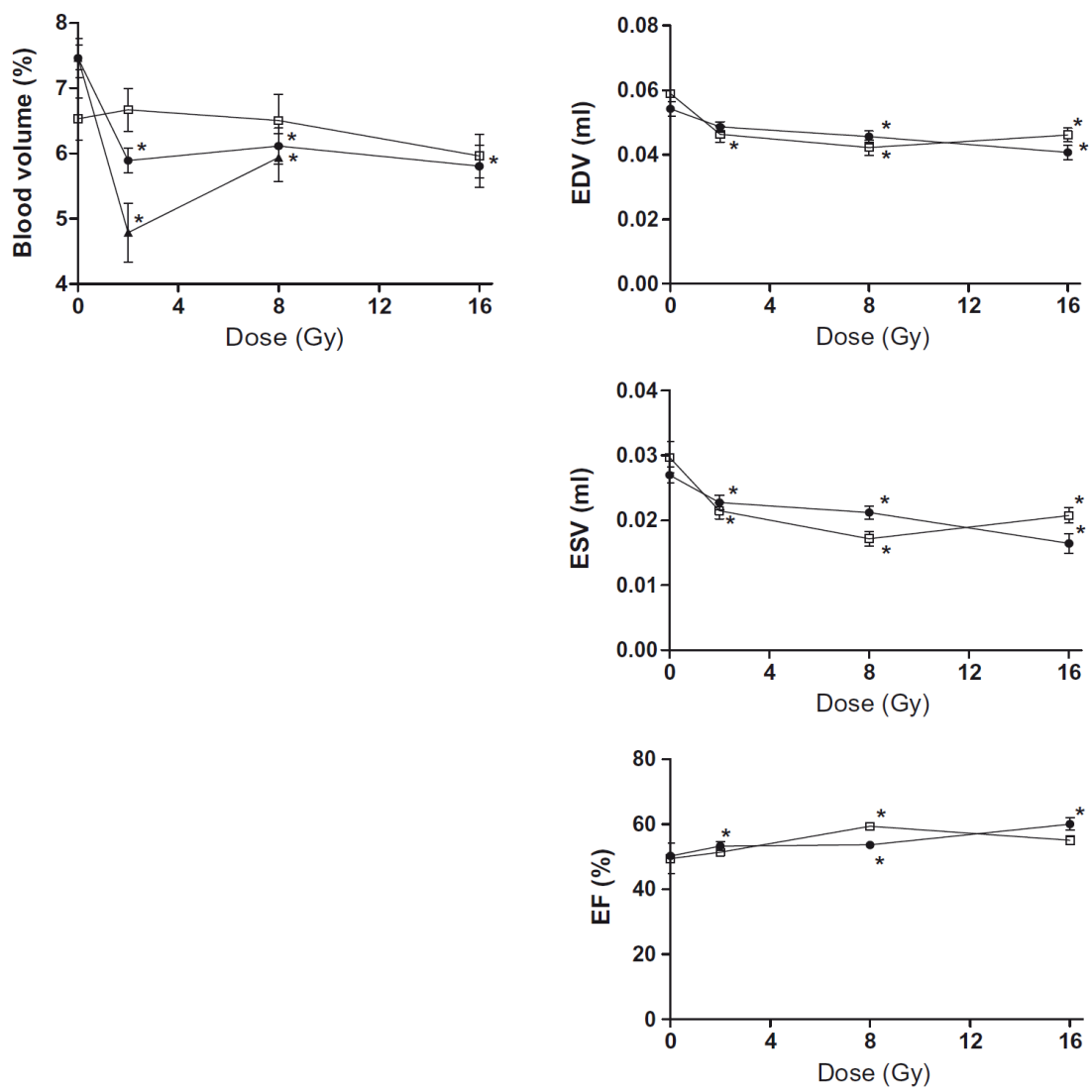

Figure 1. Cardiac blood volume (A) or EDV, ESV and EF (B) at 20 weeks (•), 40 weeks ( $\square$ ) or 60 weeks $(\boldsymbol{\Delta})$ after irradiation or sham-treatment. Values represent mean \pm SEM (9-18 mice in each irradiated group), ${ }^{*} p<0.05$ compared to age-matched controls.
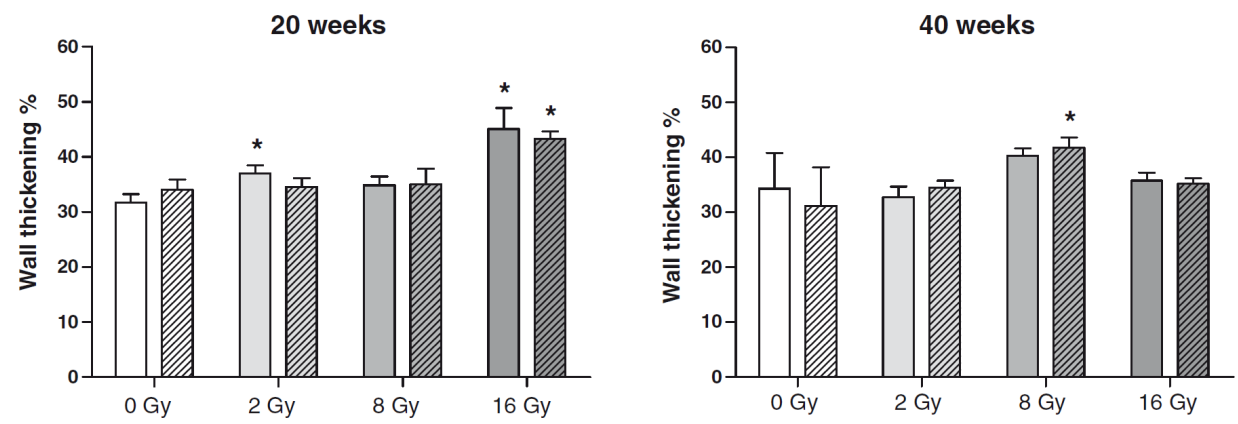

Figure 2. Mean LV wall thickening at anterior (solid bars) and posterior (hatched bars) positions 20 and 40 weeks after irradiation (mean \pm SEM). Values represent mean \pm SEM (9-18 mice in each irradiated group), ${ }^{*} p<0.05$ compared to age-matched controls. 
Inflammatory and fibrotic changes in irradiated hearts

The epicardium and myocardium of irradiated and age-matched control mice were examined for evidence of inflammatory and fibrotic changes. At 20 weeks, doses of 8 and 16 Gy resulted in increased epicardial thickness (Figure 3A), associated with the presence of CD45-positive inflammatory cells (Figure 3B) and iron-containing macrophages (Table 2), indicative of previous hemorrhage. At 40 weeks, epicardial thickening and increased numbers of CD45-positive inflammatory cells (per section) were found after 16 Gy (Figure $3 \mathrm{~A}$ and $\mathrm{B}$ ). Doses of 2 and $8 \mathrm{~Gy}$ also resulted in epicardial thickening relative to age-matched controls, but not with respect to other control groups. Ironcontaining macrophages were still present at 40 weeks in the epicardium of all hearts after 8 and 16 Gy (Table 2). At 60 weeks, there was no evidence of increased epicardial thickening or inflammation after 2 or 8 Gy (Figure 3A and B) and the incidence of hearts with iron-containing macrophages was reduced compared to 40 weeks.

The number of CD45-positive inflammatory cells (per section) in the myocardium increased significantly at 40 weeks after $16 \mathrm{~Gy}$, but not at earlier times or lower doses (Figure $\mathbf{3 C}$ ). Iron-containing macrophages were found in the myocardium of all these hearts, as well as at 20 weeks after 8 and $16 \mathrm{~Gy}$ (Table 2). The amount of interstitial collagen in the LV myocardium was significantly increased at 40 weeks after 8 and 16 Gy and 60 weeks after 2 and $8 \mathrm{~Gy}$, although this was never more than $2-5 \%$ of the tissue area (Figure 3D). Analysis of the mean size of individual myocytes showed transient increased size (indicative of swelling) at 20 weeks after $16 \mathrm{~Gy}$, followed by reduced myocyte cell size in irradiated hearts at later times after all doses (Supplemental Figure II on page 139). 

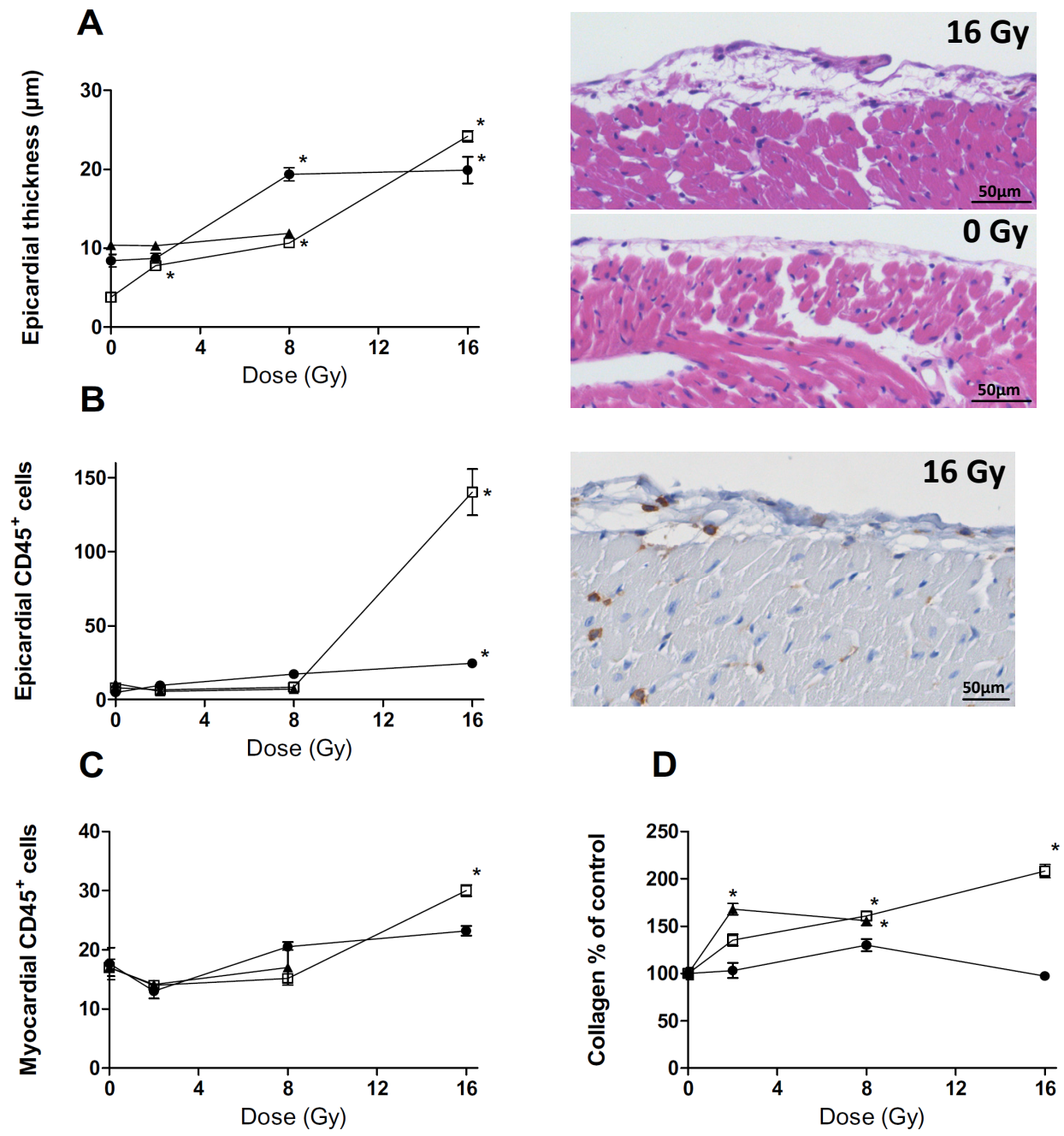

Figure 3. Inflammatory and fibrotic changes at 20 weeks $(\bullet), 40$ weeks $(\square)$ or 60 weeks $(\mathbf{\Delta})$ after irradiation or sham-treatment. Values represent mean \pm SEM (with at least 4-7 mice in each irradiated group), ${ }^{*} p<0.05$ compared to age-matched controls. (A) Epicardial thickness and H\&E photographs illustrate extensive fibrous thickening after irradiation. (B) Quantification and photograph (16 Gy, 20 weeks) of $\mathrm{CD}^{+} 5^{+}$cells per section in the epicardium and (C) myocardium. (D) Percentage interstitial collagen content of irradiated heart sections, relative to age-matched controls. 
Table 2. Perl's staining at $20-60$ weeks after irradiation demonstrates increased incidence of iron-containing macrophages in the epicardium and myocardium.

\begin{tabular}{lll}
\hline & Epicard & Myocard \\
\hline 20 Weeks & & \\
$0 \mathrm{~Gy}$ & $0 / 4$ & $0 / 4$ \\
$2 \mathrm{~Gy}$ & $0 / 5$ & $0 / 5$ \\
$8 \mathrm{~Gy}$ & $9 / 9^{*}$ & $9 / 9^{*}$ \\
$16 \mathrm{~Gy}$ & $10 / 10^{*}$ & $10 / 10^{*}$ \\
40 Weeks & & \\
$0 \mathrm{~Gy}$ & $0 / 8$ & $4 / 8$ \\
$2 \mathrm{~Gy}$ & $2 / 8$ & $7 / 8$ \\
$8 \mathrm{~Gy}$ & $8 / 8^{*}$ & $7 / 8$ \\
$16 \mathrm{~Gy}$ & $14 / 14^{*}$ & $14 / 14^{*}$ \\
60 Weeks & & \\
$0 \mathrm{~Gy}$ & $0 / 5$ & $2 / 5$ \\
$2 \mathrm{~Gy}$ & $2 / 7$ & $5 / 7$ \\
$8 \mathrm{~Gy}$ & $3 / 5$ & $2 / 5$ \\
$16 \mathrm{~Gy}$ & $\mathrm{ND}$ & $\mathrm{ND}$ \\
\hline
\end{tabular}

* Indicates significant differences between irradiated and age-matched control groups $(p<0.05$; Mann-Whitney U-test), ND = not determined.

Microvascular density (MVD) and vascular function in irradiated hearts

Doses of 2 and $8 \mathrm{~Gy}$ led to a transient increase (16-24\%) in MVD at 20 weeks, relative to age-matched controls. At 40 weeks MVD was comparable between controls and 2 and $8 \mathrm{~Gy}$, but there was a significant decrease after $16 \mathrm{~Gy}$ (26\%). By 60 weeks MVD was significantly decreased after 8 Gy (23\%), indicative of progressive loss of microvessels in a dose and time dependent way (Figure 4A). However, the loss of MVD did not lead to marked impairment of perfusion or tissue hypoxia. In 40-week age-matched controls, $87 \%$ of microvessels were functionally perfused (positive for CD31 and FITC-lectin), compared with 84\% at 40 weeks after $16 \mathrm{~Gy}$. There was a total absence of severe hypoxia in both control and irradiated hearts, since all sections were completely negative for EF5 staining, whereas positive control samples of mouse tumor sections (processed together with the heart sections) demonstrated clear areas of EF5 staining.

To further investigate functional changes in the microvasculature, the amount of endothelial cell ALP was quantified (Figure 4B). At 20 weeks after irradiation with 8 and $16 \mathrm{~Gy}$, there was a significant decrease (30-44\%) in percentage tissue stained for ALP, relative to age-matched controls. By 40 weeks, the 2 Gy dose group also had significantly less ALP expression, 
indicative of further progression of endothelial damage in small blood vessel. At 60 weeks the ALP expression in irradiated groups ( 2 and $8 \mathrm{~Gy}$ ) was $50 \%$ of the mean control value, but these differences were borderline significant compare to age-matched controls $(p=0.05)$.

Analysis of the pro-thrombotic endothelial marker vWF showed significant increases at 20 weeks after 8 and 16 Gy and 40 weeks after 16 Gy (Figure 4C). By 60 weeks no differences between groups were observed. Semiquantitative analysis of VCAM-1 expression in endothelial cells showed significant increases at 20 weeks after 2 and 16 Gy and 40 weeks after 8 Gy (Supplemental Table I on page 138). There were no significant changes in the amount of thrombomodulin expression at 20 to 60 weeks after irradiation, relative to age-matched controls (data not shown).

A
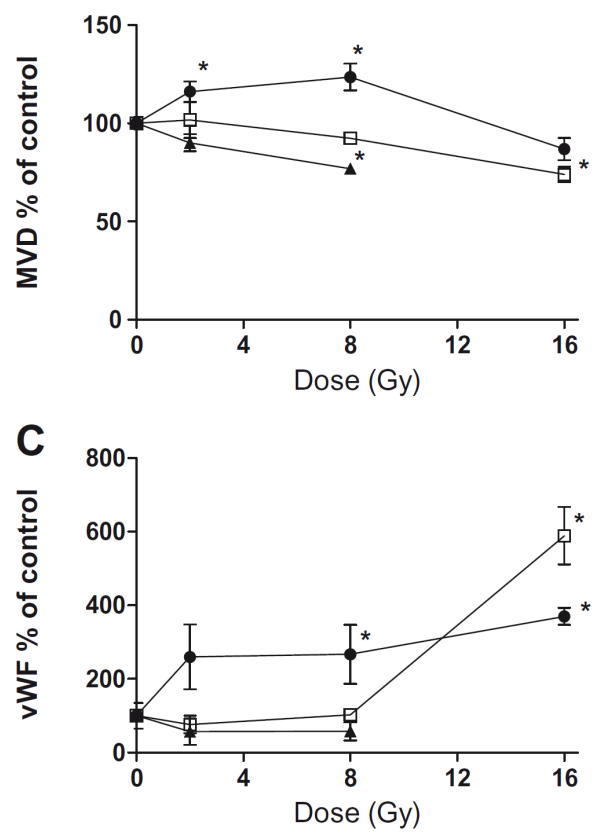

B

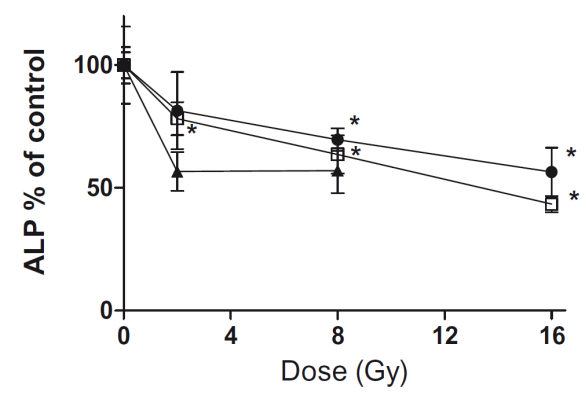

Figure 4. Microvascular alterations at 20 weeks $(\bullet), 40$ weeks $(\square)$ or 60 weeks $(\boldsymbol{\Delta})$ after irradiation or sham-treatment (Mean \pm SEM with at least 4-7 mice in almost all groups). ${ }^{*} p<$ 0.05 compared to age-matched controls. (A) MVD per unit area expressed as percentage of agematched control values. (B) ALP positive tissue areas as $\%$ of age-matched unirradiated controls. (C) VWF positive tissue areas as $\%$ of age-matched controls. 
To investigate whether these structural and functional changes in the microvasculature were associated with vascular leakage, albumin deposition in the myocardium was examined. At 40 weeks, half of the hearts irradiated with $2 \mathrm{~Gy}$ and almost all hearts irradiated with 8 or $16 \mathrm{~Gy}$ showed albumin in the myocardium (Figure 5). Only one age-matched control heart showed mild albumin deposition in the myocardium. After $16 \mathrm{~Gy}$, myocardial albumin was extensive in 5 of 11 hearts and all these animals also had diffuse amyloidosis, which was confirmed with a Congo red staining (Figure 5B and C). Of the remaining 6 animals from this group, 5 hearts showed mild albumin deposition and all these also had focal amyloidosis (Figure 5A).

Incidence of hearts with albumin protein deposition in the myocardium

$\begin{array}{lccc}20 \text { weeks } & \begin{array}{c}\text { mild deposition } \\ \text { ND }\end{array} & \begin{array}{c}\text { strong deposition } \\ \text { ND }\end{array} & \begin{array}{c}\text { any deposition } \\ \text { ND }\end{array} \\ 40 \text { weeks } & & & 1 / 5 \\ 0 \text { Gy } & 1 / 5 & 0 / 5 & 4 / 8 \\ 2 \text { Gy } & 4 / 8 & 0 / 8 & 8 / 8 \text { * } \\ 8 \text { Gy } & 8 / 8 * & 0 / 8 & 10 / 11^{*} \# \\ 16 \text { Gy } & 5 / 11 & 5 / 11 & \end{array}$

$\begin{array}{llll}60 \text { weeks } & & & \\ 0 \mathrm{~Gy} & 1 / 5 & 2 / 5 & 3 / 5 \\ 2 \mathrm{~Gy} & 3 / 7 & 1 / 7 & 4 / 7 \\ 8 \mathrm{~Gy} & 2 / 4 & 2 / 4 & 4 / 4 \\ 16 \mathrm{~Gy} & \mathrm{ND} & \mathrm{ND} & \mathrm{ND}\end{array}$
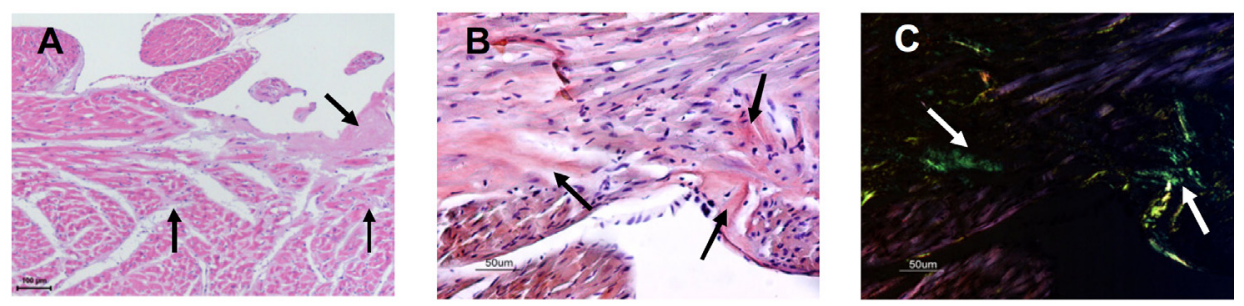

Figure 5. Evidence for blood vessel leakage after irradiation. (A) H\&E staining showing amyloid deposition (arrows). (B) Amyloidosis was confirmed by Congo-Red staining and (C) yellow-green birefringence by polarizing microscopy at 40 weeks after $16 \mathrm{~Gy}$. Incidence of hearts showing increased expression of plasma protein albumin outside blood vessels. ${ }^{*} p<0.05$ compared to age-matched controls. \# Hearts showing strong albumin protein deposition also had diffuse amyloidosis. $\mathrm{ND}=$ not determined. 


\section{Discussion}

This study demonstrated that irradiation affected cardiac structure and microvascular function in a dose- and time-dependent manner, with substantial damage after intermediate and high dose irradiation ( 8 and $16 \mathrm{~Gy}$ ) and minor alterations after lower doses ( $2 \mathrm{~Gy}$ ). Moreover, high doses induced changes at earlier time points and these effects progressed in time.

The transient increase in MVD at 20 weeks after 2 and 8 Gy was presumably due to stimulated proliferation in response to damage, whereas proliferation after $16 \mathrm{~Gy}$ was counterbalanced by endothelial cell loss. The decreased MVD at 40-60 weeks after high doses confirms earlier studies in irradiated rat hearts. ${ }^{16}$ However, this did not lead to a marked loss of vascular perfusion and no severe hypoxia was detected.

Despite the lack of hypoxia, progressive microvasculature damage was indicated by the vascular leakage, decreased amount of endothelial cell ALP and increased VWF in irradiated hearts. ALP is abundantly present in healthy cardiac microvasculature whereas loss of ALP is indicative of endothelial cell damage. ${ }^{16}$ ALP expression was significantly reduced at 20 weeks after doses of 8 or 16 Gy and after 2, 8 or 16 Gy at 40 and 60 weeks. Increased deposition of VWF in irradiated rat hearts has been previously described as an indicator of thrombotic endothelial cell damage. ${ }^{17}$ In our studies, increases in VWF deposition were limited to hearts that received 8 or $16 \mathrm{~Gy}$, with the largest increase at later times after the highest dose. Myocardial deposition of albumin (indicative of vascular leakage) was seen in almost all hearts examined at 40 weeks after 8 and $16 \mathrm{~Gy}$, and this was strongly correlated with amyloidosis. All of the hearts exhibiting strong extracellular albumin deposition at 40 weeks after $16 \mathrm{~Gy}$ also had diffuse amyloidosis and those with mild albumin deposition had focal amyloidosis. Amyloidosis is caused by extracellular deposition of insoluble, abnormal fibrils, derived from aggregation of misfolded proteins. A prominent clinical feature of cardiac amyloidosis is heart failure. ${ }^{18}$ The presence of amyloidosis may therefore have contributed to the sudden death seen in $38 \%$ of mice between 30 and 40 weeks after $16 \mathrm{~Gy}$.

Changes in cardiac function after irradiation were modest and non progressive, despite the progressive deterioration of microvascular structure 
and function. This suggests that in mice the myocardium can compensate for structural degeneration to some extent. However, $16 \mathrm{~Gy}$ lead to sudden death at 30-40 weeks in a significant proportion of mice. It was only possible to autopsy a few of these mice so the exact cause of death remained unclear. The cardiac function at 20 weeks, for those mice that subsequently died, was comparable to mice which completed 40 weeks follow up after $16 \mathrm{~Gy}$ (Supplemental Figure III on page 139). There was also no indication of arrhythmia at 20 weeks in these mice. However, neither cardiac function nor histological analyses were done between 20 weeks and sudden death of these mice; therefore it remains possible that they subsequently developed conduction defects leading to arrhythmia and sudden cardiac death. ${ }^{19}$ We suspect that amyloidosis may be involved in the sudden deaths seen after 16 Gy, since 4 of 7 mice that died immediately after their 40 week imaging procedure did have diffuse amyloidosis. These sudden deaths imply that compensatory mechanisms seen after low to intermediate doses ( 2 and $8 \mathrm{~Gy}$ ), especially at earlier times, can not maintain cardiac function after high dose irradiation.

There is some evidence from in vitro studies that cardiomyocytes can react to stress signals directly by initiating an inflammatory response. ${ }^{20}$ This response leads to the presence of macrophages, which can interact with cardiac myocytes and lead to decreased myocyte contractility, both in vitro and in vivo, resulting in a decrease in systolic and diastolic filling. ${ }^{21}$ We also observed this effect in our mouse model after irradiation. Decreased myocyte cell area and increased collagen deposition after irradiation may also have contributed to impaired myocardial contractility. ${ }^{22}$ Sarcoplasmic reticulum $\mathrm{Ca}^{2+}$ ATPase (SERCA) has been described as a compensatory mechanism in failing human myocardium, by maintaining relaxation and contraction of cardiomyocytes. However, this remains speculative and further investigations are necessary to understand compensatory mechanisms in the damaged heart. $^{20}$

In conclusion, these studies demonstrated decreases in both systolic and diastolic volumes and increased ejection fractions at 20-40 weeks after irradiation. The presence of inflammatory cells and iron-containing macrophages within the thickened epicardium suggests this could be due to constrictive pericarditis. This constrictive remodeling of the heart could also 
lead to loss of normal blood filling and emptying during diastole and systole. However, the overall cardiac function remained within normal physiological limits, which suggests that compensatory mechanisms can initially maintain cardiac function after irradiation, despite deteriorating underlying morphology and vascular function. Ultimately, however, this compensatory mechanism fails, leading to sudden death. 


\section{Supplemental data}

Supplemental Table I. Incidence of hearts with VCAM-1 expression in the myocadium.

\begin{tabular}{lccc}
\hline & mild expression & strong expression & any expression \\
\hline 20 weeks & & & \\
$0 \mathrm{~Gy}$ & $0 / 4$ & $0 / 4$ & $0 / 4$ \\
$2 \mathrm{~Gy}$ & $3 / 4$ & $1 / 4$ & $4 / 4^{*}$ \\
$8 \mathrm{~Gy}$ & $2 / 4$ & $0 / 4$ & $2 / 4$ \\
$16 \mathrm{~Gy}$ & $1 / 4$ & $3 / 4$ & $4 / 4^{*}$ \\
& & & \\
40 weeks & & & \\
$0 \mathrm{~Gy}$ & $2 / 10$ & $0 / 10$ & $2 / 10$ \\
$2 \mathrm{~Gy}$ & $3 / 7$ & $0 / 7$ & $3 / 7$ \\
$8 \mathrm{~Gy}$ & $5 / 10$ & $4 / 10$ & $9 / 10^{*}$ \\
$16 \mathrm{~Gy}$ & $7 / 14$ & $1 / 14$ & $8 / 14$ \\
& & & \\
60 weeks & & & $7 / 7$ \\
$0 \mathrm{~Gy}$ & $7 / 7$ & $0 / 7$ & $5 / 5$ \\
$2 \mathrm{~Gy}$ & $2 / 5$ & $3 / 5$ & $4 / 4$ \\
$8 \mathrm{~Gy}$ & $2 / 4$ & $\mathrm{ND}$ \\
$16 \mathrm{~Gy}$ & $2 / 4$ & $\mathrm{ND}$ & \\
\hline
\end{tabular}

* indicates significant differences between irradiated and age-matched control groups $(p<0.05$; Mann-Whitney U-test). ND = not determined.

20 weeks
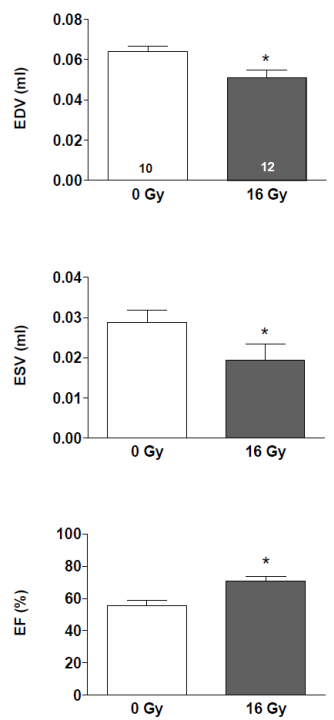

40 weeks
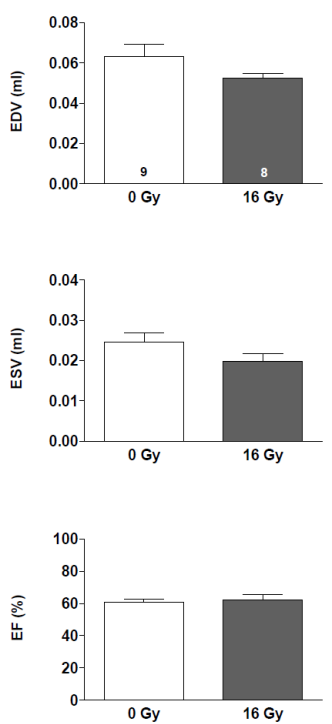

Supplemental Figure I. Ultrasound measurements (mean \pm SEM) of EDV, ESV and EF for control and $16 \mathrm{~Gy}$ mice at 20 and 40 weeks. Numbers of mice indicated in the bars. ${ }^{*} p<0.05$ compared to age-matched controls. 
A 20 weeks

B
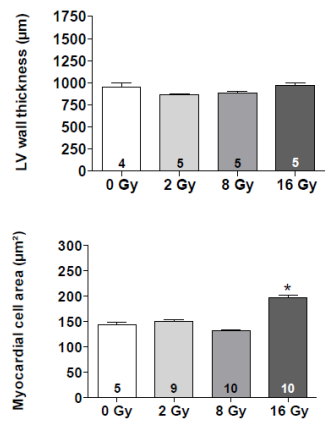

40 weeks
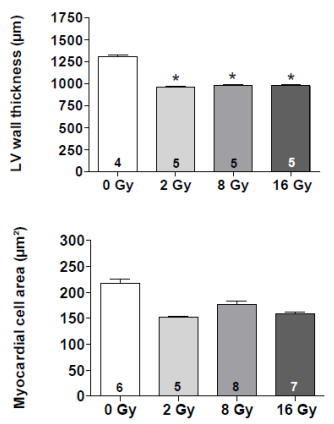

60 weeks
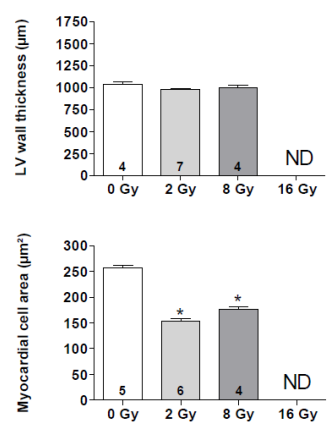

Supplemental Figure II. Myocardial alterations 20-60 weeks after irradiation (mean \pm SEM with numbers of mice per group indicated). ${ }^{*} p<0.05$ compared to age-matched controls. (A) LV wall thickness. (B) Mean myocardial cell area.

A

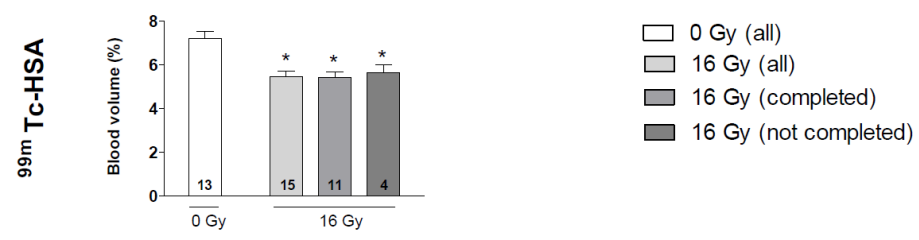

B
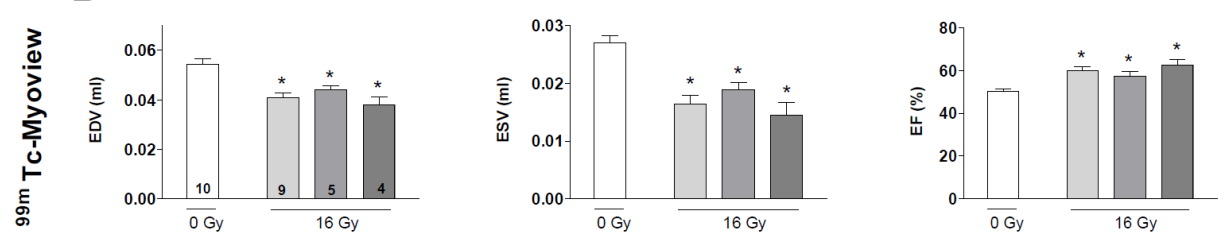

Supplemental Figure III. Non-invasive imaging for measurement of cardiac function in unirradiated and age-matched irradiated groups at 20 weeks after treatment, including $16 \mathrm{~Gy}$ treated mice that suddenly died between 30-40 weeks. (A) SPECT/CT, using ${ }^{99 \mathrm{~m}} \mathrm{Tc}-\mathrm{HSA}$ measurements of mean cardiac blood volume (\% total) \pm SEM. (B) Gated SPECT/CT measurements with ${ }^{99 m}$ Tc-Myoview. Values represent mean \pm SEM, numbers of mice indicated in the bars. ${ }^{*} p<0.05$ compared to age-matched controls, (all) representing total number of mice of group $0 \mathrm{~Gy}$ and $16 \mathrm{~Gy}$, (completed) representing number of mice that completed 40 weeks follow up, (not completed) representing number of mice that died before 40 weeks. 


\section{References}

1. McGale P, Darby SC, Hall P et al. Incidence of heart disease in 35,000 women treated with radiotherapy for breast cancer in Denmark and Sweden. Radiother Oncol. 2011;100:167-175.

2. Gyenes G, Rutqvist LE, Liedberg A and Fornander T. Long-term cardiac morbidity and mortality in a randomized trial of pre- and postoperative radiation therapy versus surgery alone in primary breast cancer. Radiother Oncol. 1998;48:185-190.

3. Cohn KE, Stewart JR, Fajardo LF and Hancock EW. Heart disease following radiation. Medicine (Baltimore). 1967;46:281-298.

4. Armstrong GT, Stovall M and Robison LL. Long-term effects of radiation exposure among adult survivors of childhood cancer: results from the childhood cancer survivor study. Radiat Res. 2010;174:840-850.

5. Galper SL, Yu JB, Mauch PM et al. Clinically significant cardiac disease in patients with Hodgkin lymphoma treated with mediastinal irradiation. Blood. 2011;117:412-418.

6. Darby SC, Cutter DJ, Boerma $M$ et al. Radiation-related heart disease: current knowledge and future prospects. Int J Radiat Oncol Biol Phys. 2010;76:656-665.

7. Aleman BM, van den Belt-Dusebout AW, Klokman WJ, Van't Veer MB, Bartelink $\mathrm{H}$ and van Leeuwen FE. Long-term cause-specific mortality of patients treated for Hodgkin's disease. J Clin Oncol. 2003;21:3431-3439.

8. Adams MJ, Hardenbergh PH, Constine LS and Lipshultz SE. Radiation-associated cardiovascular disease. Crit Rev Oncol Hematol. 2003;45:55-75.

9. Yusuf SW, Sami S and Daher IN. Radiation-induced heart disease: a clinical update. Cardiol Res Pract. 2011;2011:317659.

10. Andratschke N, Maurer J, Molls M, Trott KR. Late radiation-induced heart disease after radiotherapy. Clinical importance, radiobiological mechanisms and strategies of prevention. Radiother Oncol. 2011;100:160-166.

11. Fajardo LF, Stewart JR. Capillary injury preceding radiation-induced myocardial fibrosis. Radiology. 1971;101:429-433.

12. Lauk S, Kiszel Z, Buschmann J and Trott KR. Radiation-induced heart disease in rats. Int J Radiat Oncol Biol Phys. 1985;11:801-808.

13. Schultz-Hector S, Trott KR. Radiation-induced cardiovascular diseases: is the epidemiologic evidence compatible with the radiobiologic data? Int J Radiat Oncol Biol Phys. 2007;67:10-18.

14. Marks LB, Yu X, Prosnitz RG et al. The incidence and functional consequences of RTassociated cardiac perfusion defects. Int J Radiat Oncol Biol Phys. 2005;63:214-223.

15. Seddon B, Cook A, Gothard $L$ et al. Detection of defects in myocardial perfusion imaging in patients with early breast cancer treated with radiotherapy. Radiother Oncol. 2002;64:53-63.

16. Schultz-Hector S, Balz K. Radiation-induced loss of endothelial alkaline phosphatase activity and development of myocardial degeneration. An ultrastructural study. Lab Invest. 1994;71:252-260.

17. Boerma M, Kruse JJ, van Loenen M et al. Increased deposition of von Willebrand factor in the rat heart after local ionizing irradiation. Strahlenther Onkol. 2004;180:109-116.

18. McCarthy RE, III, Kasper EK. A review of the amyloidoses that infiltrate the heart. Clin Cardiol. 1998;21:547-552.

19. Heidenreich PA, Kapoor JR. Radiation induced heart disease: systemic disorders in heart disease. Heart. 2009;95:252-258. 
20. Boyd JH, Kan B, Roberts $H$, Wang $Y$ and Walley KR. S100A8 and S100A9 mediate endotoxin-induced cardiomyocyte dysfunction via the receptor for advanced glycation end products. Circ Res. 2008;102:1239-1246.

21. Simms MG, Walley KR. Activated macrophages decrease rat cardiac myocyte contractility: importance of ICAM-1-dependent adhesion. Am J Physiol. 1999;277:H253-H260.

22. Kruse JJ, Zurcher C, Strootman EG et al. Structural changes in the auricles of the rat heart after local ionizing irradiation. Radiother Oncol. 2001;58:303-311. 



\section{chapter six}

\section{Local heart irradiation of $\mathrm{ApoE}^{-/}$mice induces microvascular and endocardial damage and accelerates coronary atherosclerosis}

\footnotetext{
Karen Gabriels*, Saske Hoving*, Ingar Seemann, Nils L. Visser, Marion J. Gijbels, Jeffrey F. Pol, Mat J. Daemen, Fiona A. Stewart", Sylvia.Heeneman ${ }^{\#}$

*Authors contributed equally (performing experiments and analyses) "Authors contributed equally. (designing and supervision of the study)
}

Radiotherapy and Oncology 2012;105(3):358-64 


\section{Abstract}

Background and purpose: Radiotherapy of thoracic and chest-wall tumors increases the long-term risk of radiation-induced heart disease, such as a myocardial infarction. Cancer patients commonly have additional risk factors for cardiovascular disease, such as hypercholesterolemia. The goal of this study is to define the interaction of irradiation with such cardiovascular risk factors in radiation-induced damage to the heart and coronary arteries.

Material and methods: Hypercholesterolemic and atherosclerosis-prone $A p o E^{\prime-}$ mice received local heart irradiation with a single dose of $0,2,8$ or 16 Gy. Histopathological changes, microvascular damage and functional alterations were assessed after 20 and 40 weeks.

Results: Inflammatory cells were significantly increased in the left ventricular myocardium at 20 and 40 weeks after 8 and 16 Gy. Microvascular density decreased at both follow-up time-points after 8 and $16 \mathrm{~Gy}$. Remaining vessels had decreased alkaline phosphatase activity (2-16 Gy) and increased von Willebrand Factor expression (16 Gy), indicative of endothelial cell damage. The endocardium was extensively damaged after $16 \mathrm{~Gy}$, with foam cell accumulations at 20 weeks, and fibrosis and protein leakage at 40 weeks.

Despite an accelerated coronary atherosclerotic lesion development at 20 weeks after $16 \mathrm{~Gy}$, gated SPECT and ultrasound measurements showed only minor changes in functional cardiac parameters at 20 weeks.

Conclusions: The combination of hypercholesterolemia and local cardiac irradiation induced an inflammatory response, microvascular and endocardial damage, and accelerated the development of coronary atherosclerosis. Despite these pronounced effects, cardiac function of $\mathrm{ApoE}^{-/}$mice was maintained. 


\section{Introduction}

Improvements in cancer therapy and earlier detection and diagnosis have lead to increasing numbers of cancer survivors. Unfortunately, this also means that more patients are at risk of developing treatment-related late tissue damage and mortality. Thoracic radiotherapy, given to Hodgkin's lymphoma and breast cancer patients, is widely recognized as an independent long-term risk factor for developing heart diseases. ${ }^{1-4}$ The pathological consequences of radiationinduced heart disease following therapeutic irradiation are pericarditis, myocardial fibrosis, coronary artery disease, valvular disorders and conduction abnormalities. $^{5-7}$

In a previous study ${ }^{8}$, the dose and time dependence of structural and functional cardiovascular damage after thoracic irradiation were investigated in C57BL/6j mice. Inflammation, especially in the epicardium, and microvascular endothelial damage leading to vascular leakage progressed with dose (2-16 Gy) and time (20-60 weeks follow-up). However, only modest and nonprogressive changes in cardiac function, detected by gated SPECT, were observed in mice surviving cardiac irradiation of 2 and $8 \mathrm{~Gy}$. These data indicated that the heart was able to compensate for the structural damage. Nevertheless, $16 \mathrm{~Gy}$ irradiation led to excessive protein leakage in the myocardium and $38 \%$ of mice failed to maintain cardiac function at 40 weeks follow-up.

C57BL/6j mice have extremely low plasma levels of cholesterol, especially low-density lipoproteins, and they are resistant to the development of atherosclerosis. ${ }^{9}$ Cardiac damage identified after irradiation in such models therefore does not include any component of macrovascular damage as a result of accelerated atherosclerosis.

The effect of irradiation on the development of atherosclerosis has been studied in apolipoproteinE ${ }^{-/-}\left(A p o E^{-/}\right)$mice, which have elevated cholesterol levels and do develop age-related atherosclerosis. After local carotid artery irradiation with a single dose of $14 \mathrm{~Gy}$ or fractionated doses ( $20 \times 2 \mathrm{~Gy}$ ), an accelerated development of inflammatory atherosclerotic plaques was observed. ${ }^{9,10} \mathrm{Hu}$ et al. ${ }^{11}$ described the distribution of atherosclerotic lesions in the coronary arteries of 60 week old $A p o E^{-/}$mice and found relatively few lesions (approximately 4 lesions per heart) after the second level of branching 
of the coronary arteries, that developed independently from valvular lesions. However, the effect of irradiation on this coronary lesion development is not known.

The aim of this study is to investigate the effect of local thoracic irradiation of hypercholesterolemic $A p o E^{-/}$mice on cardiac structure and function, and to compare this with previous results of irradiated wild-type C57BL/6j mice in the absence of atherosclerosis ${ }^{8}$. This should allow us to evaluate the contribution of macrovascular (atherosclerosis) and microvascular changes in the pathology of radiation-induced cardiac damage.

\section{Material and methods}

\section{Mice and irradiation procedure}

Male $\mathrm{ApoE}^{-/}$mice (C57BL/6j background), aged 10-12 weeks (bred at The Netherlands Cancer Institute), were housed in a temperature-controlled room with $12 \mathrm{~h}$ light-dark cycle and received standardized mouse chow $(3.7 \%$ fat, RMI (E) SQC, SDS, London, UK) and water ad libitum.

Irradiation procedure was performed as described previously. Mice were randomly allocated to receive single doses of 2, 8 or $16 \mathrm{~Gy}$ locally to the heart (irradiation field of $10.6 \times 15.0 \mathrm{~mm}$, including $30 \%$ lung volume) at a dose rate of $0.94 \mathrm{~Gy} / \mathrm{min}$ using $250 \mathrm{kV}$ X-rays, operating at $12 \mathrm{~mA}$ and filtered with $0.6 \mathrm{~mm}$ of copper, or sham-treatment ( $0 \mathrm{~Gy}$ ) as a control. Mice were sacrificed 20 or 40 weeks after irradiation, and hearts and lungs were collected.

Experiments were in agreement with the Dutch law on animal experiments and welfare, and in line with the international Guide for the Care and Use of Laboratory Animals (eighth edition).

\section{Tissue preparation and histology}

The heart was perfused via the aortic arch (retro-grade) with phosphatebuffered saline (PBS) (frozen sections) or PBS followed by $1 \%$ paraformaldehyde (paraffin sections), under lethal sodium pentobarbital anesthesia (18 mg i.p. per mouse). Immediately after perfusion, the heart was excised, divided into three parts (base, mid and apex) and frozen on dry ice or immersed in $1 \%$ paraformaldehyde. Cross-sections were cut at the level of the 
mid-horizontal plane of the heart from fixed paraffin-embedded tissues $(3 \mu \mathrm{m})$ or frozen tissues $(7 \mu \mathrm{m})$.

\section{Paraffin sections}

Sections were immuno-labeled with anti-CD45 antibody (1:5000, Becton\&Dickinson, Franklin lakes, USA) or anti-CD3 antibody (1:200, Dako, Carpinteria, USA) to determine the extent of leukocyte and T-cell infiltration, respectively. The absolute number of CD45-positive leukocytes per section was counted in the left ventricular (LV) myocardium. The number of CD3-positive T cells was counted per LV myocardial area (8 random 40x photographs). Interstitial collagen was quantified in 5 randomly selected areas of the LV myocardium based on a Sirius Red staining and results were expressed as percentage tissue positive for Sirius Red, excluding perivascular collagen, relative to myocardial area. To determine if there was a pre-mortem bleeding, a Perls' staining was performed to detect iron. Macrophages store iron by metabolizing hemoglobin from engulfed red blood cells. An albumin staining (1:2500, Abcam, Cambridge, USA) was performed to determine myocardial deposition as a measure of vascular leakage and a Congo Red staining was used as previously described ${ }^{8}$ to detect amyloid deposits in the myocardium.

To investigate coronary atherosclerotic plaque development, transverse sections of the complete mid-part of the heart were cut, stained every $57 \mu \mathrm{m}$ with hematoxylin and eosin (H\&E) and analyzed for the presence and number of coronary lesions. An average of 20 slides per heart was analyzed. Results are expressed as number of coronary lesions per mouse and mean values per group are shown. Percentage necrotic core of the coronary lesions was determined by dividing the necrotic core area by total plaque area.

\section{Frozen sections}

Sections were stained with H\&E to measure the myocardial thickness. Photographs of the LV wall were taken using a $5 x$ objective and 12 measurements per heart were performed. To detect alterations in the number of macrophages after irradiation, frozen sections were stained with anti-F4/80 antibody (1:300, AbD Serotec, Dusseldorf, Germany) and counted per LV myocardial area (8 random $40 x$ photographs). 
An anti-CD31 antibody (1:50, Becton\&Dickinson, Franklin lakes, USA) was used to visualize cardiac vasculature of the mid part of the heart and to quantify microvascular density (MVD). Five random areas (40x photographs) from transverse sections of the subendocardium were photographed with a CCD 2 - Color Microscope system, including a Zeiss AxioCam color camera (Axiocam HRc, Zeiss, Göttingen, Germany). Vessels beneath a size of 1.5 or above $200 \mu^{2}$ were automatically excluded from the measurements, to ensure that only microvasculature was counted. To determine functional changes in the microvasculature, a histochemical staining with Naphtol AS MX/DMF and fast Blue BB salt was performed to detect endothelial cell alkaline phosphatase (ALP) activity. Sections were also stained with an antibody against von Willebrand Factor (vWF) (1:4000, Abcam, Cambridge, USA) as a thrombotic marker. Photographs of whole sections stained for ALP and VWF were taken with an Aperio scanner (Scanscope-XT, Aperio technologies, Vista, USA) using a 40x objective. Analyses of the percentage myocardium positive for each marker were performed in 23 and 30 mice at 20 and 40 weeks FU respectively.

Morphometric parameters were analyzed using a computerized morphometry system (Leica Qwin V3, Leica, Rijswijk, The Netherlands).

\section{Gene expression profiling and pathway analysis}

Total RNA was isolated from frozen sections (30 slides of $30 \mu \mathrm{m}$ ) of the mid part of the heart of 17 mice at 20 weeks $\mathrm{FU}(5,4$ and 8 for respectively 0,2 and $16 \mathrm{~Gy})$ and 21 mice at 40 weeks FU (6, 7 and 8 for respectively 0, 2 and $16 \mathrm{~Gy})$ using Trizol ${ }^{\circledR}$ Reagent (Invitrogen Corporation, Carlsbad, USA) according to the manufacturer's protocol. The quantity of total RNA was measured using a spectrophotometer (NanoDrop, Thermo scientific, Wilmington, USA) followed by a quality check measured by Agilent 2100 Bioanalyzer with the RNA Integrity Number (RIN) (Agilent technologies, Santa Clara, USA). Samples with a RIN above 7 were used for DNAse treatment and amplified (350 ng per sample) using Illumina Totalprep RNA Amplification kit (Ambion, Grand Island, USA). Hybridization of aRNA to Illumina Expression Bead Chips Mouse Whole Genome (WG-6 vs. 2.0) and subsequent washing, blocking and detecting were performed according to the manufacturer's protocol (Illumina, San Diego, USA). Samples were scanned on the IlluminaR BeadArray ${ }^{\mathrm{TM}}$ 500GX Reader using 
IlluminaR Bead-Scan image data acquisition software (version 2.3.0.13). MouseWG-6 vs. 2.0 BeadChip contains the full set of MouseRef-8 BeadChip probes with additional 11.603 probes from RIKEN FANTOM2, NCBI REfSeq as well from the MEEBO database.

Before analyzing, the database was normalized using the robust spline normalization method within the microarray facility of The Netherlands Cancer Institute. ${ }^{12}$ Log2 ratio between expression of genes from control mice and expression of genes from irradiated mice was calculated using Excel version 2003 , as well as the sum of the expression of genes from both, control and irradiated mice. According to the sum of both expressions, genes with sums below 6 were discarded. The threshold for standard deviation (SD) was set to 3 and mean \pm nSD was calculated to identify genes that are above expression 6 and above threshold 3 of SD. These gene numbers were further analyzed in Ingenuity Pathway Analysis (IPA) version September 2011 core analysis. IPA calculates a significant score for each associated network. This score indicates the likelihood that the assembly of a set of focus genes in a network could be explained by random chance alone. A score of 2 indicates a 1 in 100 chance that the focus genes are together in a network due to random chance. Therefore, networks with scores of 2 or higher have at least a $99 \%$ confidence of not being generated by random chance alone.

Gated single photon emission computed tomography (gSPECT)

The tracer tetrofosmin (Myoview, GE-healthcare, Hoevelaken, The Netherlands) was labeled with ${ }^{99 m}$ Tc-pertechnetate according to the manufacturer's protocol and injected i.v. $(150 \mu \mathrm{l})$ with a total activity of 70 MBq per mouse. Three lead electrodes (3M red Dot 2282E, 3M, St. Paul, USA) were attached to both hind paws and right front paw of the mouse and connected to the integrated electrocardiography (ECG) monitor to measure heart rate (HR). Acquisitions were started $1 \mathrm{~h}$ after injection of the tracer as described previously ${ }^{8}$. HiSPECT NG software (InVivoScope, Bioscan) was used to perform iterative reconstruction into 3D datasets. Quantitative analysis of the reconstructed datasets was performed on a clinical e.soft (syngo-based) workstation (Siemens Medical Solutions, Siemens AG, Erlangen, Germany), using algorithms to automatically reconstruct a count based 3D model of the dimensions of the LV end diastolic and systolic volumes (EDV, ESV). The 
ejection fraction (EF) was calculated based on the difference between EDV and ESV divided by EDV.

\section{D-Ultrasound}

Mice were sedated with $2 \%$ isoflurane (Forane, Abbott, Hoofddorp, The Netherlands). Echocardiography images were acquired using a Vevo 770 system (VisualSonics, Toronto, USA) using a $30 \mathrm{MHz}$ transducer with a focal depth range of $13 \mathrm{~mm}$. Acquisitions were made in B-mode long-axis, as well as short-axis view, at the papillary muscle level as described previously ${ }^{8}$. Calculations were based on the measurement of LV length and surface area during diastole and systole and the EF was calculated as described above.

\section{Statistics}

Except where otherwise stated, data are expressed as mean \pm SEM. Irradiated and control groups were compared using nonparametric Mann-Whitney Utest. Statistical analysis on data presented in tables was performed using Fisher's exact test. Group differences were considered statistically significant at $\mathrm{P}<0.05$.

\section{Results}

\section{Mouse weight}

Local heart irradiation with $16 \mathrm{~Gy}$ induced a significant increase in heart, lung and heart/body weight at 40 weeks follow-up (FU), compared to age-matched controls (Supplemental Table I on page 161). No significant differences were observed after lower doses or at 20 weeks after 16 Gy. Histological examination of lung tissue did not reveal any abnormalities after irradiation. Premature deaths were $7 \%$ and $20 \%$ of total mice (killed before the planned 20 and 40 weeks sacrifice time respectively). This was due to non-radiation induced causes such as elephant teeth, fighting or a tumor that developed spontaneously outside the irradiation field. 


\section{Increased inflammation after 8 and 16 Gy irradiation}

There were no significant differences in LV wall thickness, as measured from histological sections, at $\mathbf{2 0}$ or $\mathbf{4 0}$ weeks after irradiation (data not shown). The number of CD45-positive leukocytes was not increased at 20 weeks after irradiation, but at 40 weeks after 8 and 16 Gy there was a significant increased influx of leukocytes in the myocardium (Figure 1A). The number of CD3positive $T$ cells in the myocardium of $A p o E^{/-}$mice was significantly increased at both 20 and 40 weeks after 8 and $16 \mathrm{~Gy}$, compared to unirradiated mice (Figure 1B), while F4/80-positive macrophages showed no differences between irradiated hearts and controls (data not shown). The amount of interstitial collagen increased significantly at 20 and 40 weeks after 8 and $16 \mathrm{~Gy}$, although not more than $2 \%$ of tissue area was affected (Figure $\mathbf{2}$ ).

A
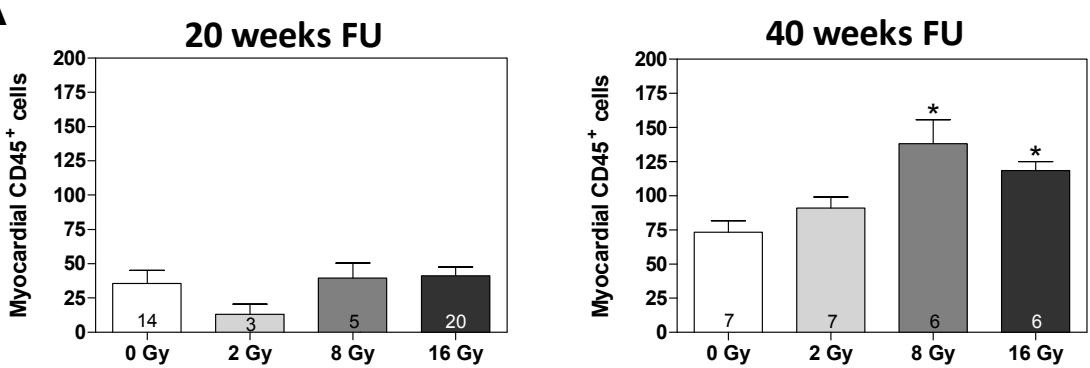

B
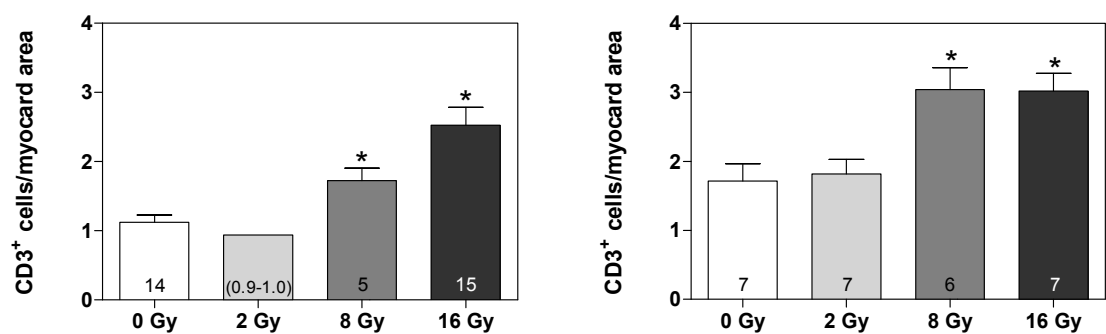

Figure 1. Inflammatory changes in the LV myocardium at $\mathbf{2 0}$ and $\mathbf{4 0}$ weeks after irradiation. (A) Number of CD45-positive leukocytes in the myocardium per section. (B) Quantification of CD3positive T cells per myocardial area (40x objective). Bars represent mean \pm SEM with numbers of mice indicated per group (the total number of mice analyzed per irradiation and FU group can differ between different stainings due to bad quality of the tissue during staining procedure). Analysis of CD3-positive T cells at 20 weeks after 2 Gy was only possible on 2 mice, therefore values are presented in the bar. ${ }^{*} P<0.05$ compared to age-matched controls. 

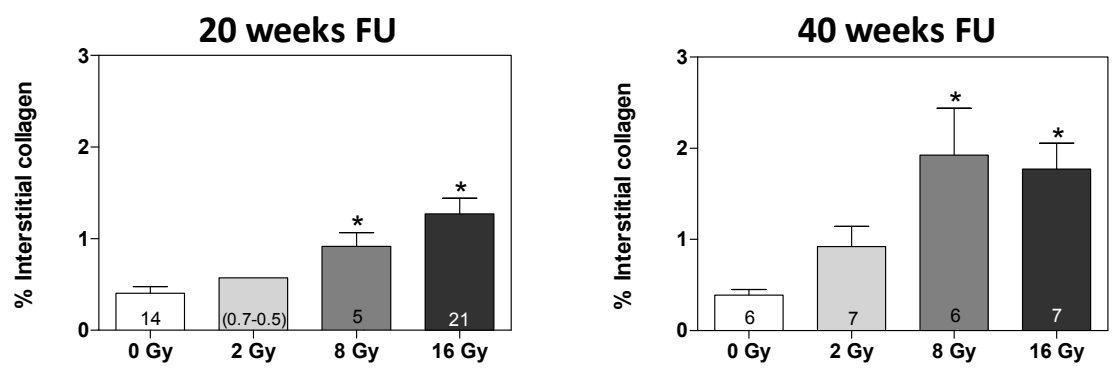

Figure 2. Fibrotic changes in the LV myocardium at 20 and $\mathbf{4 0}$ weeks after irradiation. Percentage interstitial collagen per tissue area. Bars represent mean \pm SEM with numbers of mice indicated per group. Collagen measurements at 20 weeks after $2 \mathrm{~Gy}$ were only possible on 2 mice, therefore values are presented in the bars. ${ }^{*} P<0.05$ compared to age-matched controls.

\section{Endothelial damage of microvasculature after irradiation}

At 20 and 40 weeks after 8 and 16 Gy, there was a significant decrease in MVD compared to control mice (Figure $\mathbf{3 A}$ ). In addition to the loss of capillaries, the remaining vessels had signs of endothelial damage, as indicated by a significant decrease in ALP activity at 20 and 40 weeks (2-16 Gy) (Figure 3B) and increased expression of the thrombotic marker vWF after $16 \mathrm{~Gy}$ (Figure 3C).

Perls' staining was performed to analyze the presence of iron in the myocardium, which is an indication of a previous hemorrhage. Iron-containing macrophages were observed in the myocardium of almost all 8 and $16 \mathrm{~Gy}$ irradiated hearts at 20 and 40 weeks (Table 1).

Analysis of myocardial albumin deposition, as an indication of vascular leakage, showed the presence of albumin in almost all hearts irradiated with 8 or $16 \mathrm{~Gy}$ at 40 weeks FU, but not at 20 weeks (Table 1), while amyloid deposits were not detected. 
A

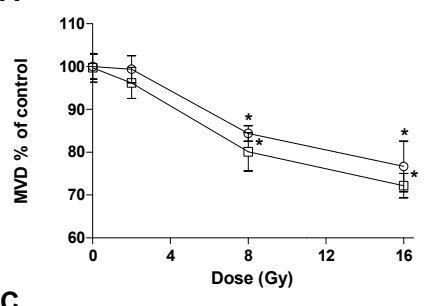

C

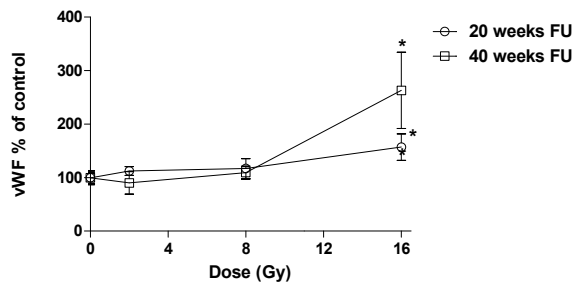

B

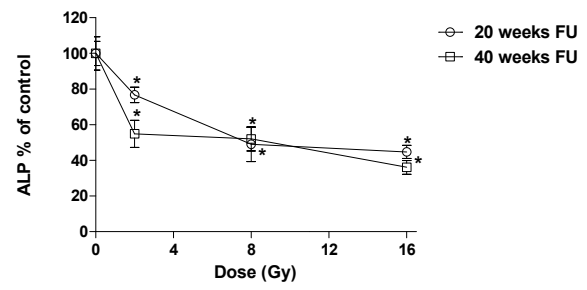

Figure 3. Microvascular alterations at $\mathbf{2 0}$ and $\mathbf{4 0}$ weeks after irradiation. (A) MVD per area expressed as percentage of 0 Gy values. (B) ALP-positive and (C) VWF-positive tissue per myocardial area expressed as percentage of age-matched controls. Number of mice included for analysis was $6,5,4$ and 8 , and $8,7,8$ and 7 at respectively 20 and 40 weeks after $0,2,8$ and 16 Gy. Values represent mean \pm SEM. ${ }^{*} P<0.05$ compared to age-matched controls.

Table 1. Incidence of mice showing iron (Fe)-containing macrophages (Perl's staining) and albumin protein deposition in the myocardium at 20 and 40 weeks after irradiation.

\begin{tabular}{lll}
\hline Treatment & Fe-containing macrophages & Albumin deposition \\
\hline 20 weeks $F U$ & & \\
0 Gy & $3 / 14$ & $0 / 14$ \\
2 Gy & $0 / 3$ & $0 / 3$ \\
8 Gy & $5 / 5^{*}$ & $0 / 5$ \\
16 Gy & $20 / 21^{*}$ & $0 / 21$ \\
40 weeks $F U$ & & \\
0 Gy & $1 / 7$ & $1 / 7$ \\
2 Gy & $1 / 7$ & $2 / 7$ \\
8 Gy & $6 / 6^{*}$ & $4 / 6$ \\
16 Gy & $5 / 7$ & $6 / 7$ \\
\hline
\end{tabular}

$* P<0.05$ compared to age-matched controls. 
Irradiation increased the number of coronary lesions and caused endocardial damage

Irradiation with 16 Gy significantly increased the number of coronary atherosclerotic lesions in the mid part of the heart at 20 weeks FU (Figure 4A and B). There was also a trend for increased numbers of lesions at 40 weeks after 8 or $16 \mathrm{~Gy}$, but this difference was no longer significant due to an increased number of age-related coronary lesions in unirradiated mice. Analysis of the necrotic core of the coronary plaques at 20 and 40 weeks FU revealed an increased level of necrosis after irradiation (an average of 33.7\% and $39.7 \%$ of plaque area was necrotic at respectively 20 and 40 weeks after $16 \mathrm{~Gy}$, compared to $0 \%$ and $1.8 \%$ after $0 \mathrm{~Gy}$ ).

The endocardium of the $16 \mathrm{~Gy}$ irradiated mice showed the appearance of foam cell accumulations, as well as erythrocyte accumulations, at 20 weeks FU (Figure 4C), which was not observed after 0,2 or 8 Gy (Table 2). At 40 weeks after 8 and 16 Gy increased endocardial collagen deposition (Table 2, Figure 4D) and fibrin deposits (confirmed by Martius Scarlet Blue staining), suggesting endocardial protein leakage (Table 2, Figure 4E and F), were observed. 
A

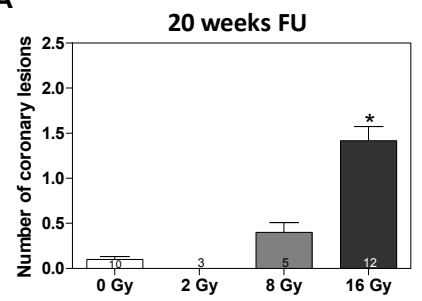

C

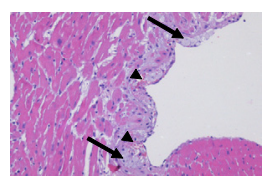

D

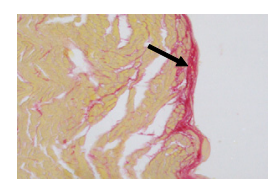

40 weeks FU

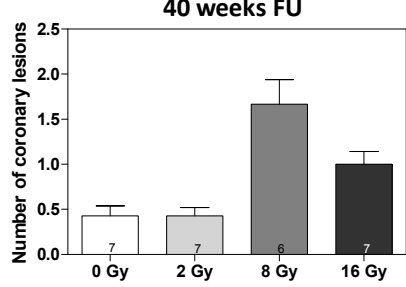

E

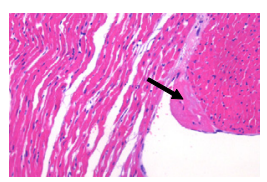

B

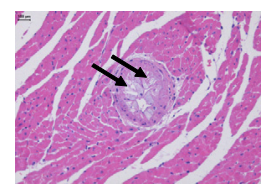

$\mathbf{F}$

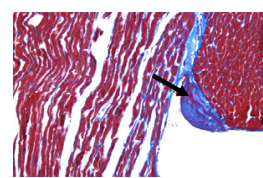

Figure 4. (A) Number of coronary atherosclerotic lesions examined in the mid-part of the heart at 20 and 40 weeks after irradiation. Bars represent mean \pm SEM with numbers of mice indicated per group. ${ }^{*} P<0.05$ compared to age-matched controls. (B) Representative H\&E photograph of a coronary atherosclerotic lesion, showing necrosis (arrows) after $16 \mathrm{~Gy}$. (C) Representative H\&E of subendocardial foam cell (arrows) and erythrocyte (arrowheads) accumulation observed at 20 weeks after 16 Gy. (D) Sirius Red photograph showing endocardial fibrosis (arrow) at 40 weeks after $16 \mathrm{~Gy}$ irradiation. (E) shows endocardial fibrin deposition on H\&E-stained section (arrow), confirmed by Martius Scarlet Blue staining (F). Photographs are taken with 20x objective.

Table 2. Incidence of hearts showing endocardial damage with foam cell accumulation at 20 weeks, and protein leakage and collagen deposition at 40 weeks after irradiation.

\begin{tabular}{lllll}
\hline Treatment & Foam cell accumulation & Protein leakage & \multicolumn{2}{l}{$\begin{array}{l}\text { Collagen } \\
\text { deposition }\end{array}$} \\
\cline { 4 - 5 } & & \multicolumn{2}{c}{ Mild } & Strong \\
\hline \multicolumn{2}{l}{20 weeks FU } & & & \\
$0 \mathrm{~Gy}$ & $0 / 10$ & $0 / 10$ & $0 / 10$ & $0 / 10$ \\
$2 \mathrm{~Gy}$ & $0 / 3$ & $0 / 3$ & $0 / 3$ & $0 / 3$ \\
$8 \mathrm{~Gy}$ & $0 / 5$ & $0 / 5$ & $0 / 5$ & $0 / 5$ \\
$16 \mathrm{~Gy}$ & $7 / 12^{*}$ & $0 / 12$ & $0 / 12$ & $0 / 12$ \\
40 weeks FU & & & \\
$0 \mathrm{~Gy}$ & $0 / 7$ & $0 / 7$ & $5 / 7$ & $2 / 7$ \\
$2 \mathrm{~Gy}$ & $0 / 7$ & $0 / 7$ & $6 / 7$ & $1 / 7$ \\
$8 \mathrm{~Gy}$ & $0 / 6$ & $2 / 6$ & $0 / 5$ & $5 / 5$ \\
$16 \mathrm{~Gy}$ & $0 / 7$ & $6 / 7^{*}$ & $2 / 6$ & $4 / 6$ \\
\hline
\end{tabular}

$* P<0.05$ compared to age-matched controls. 
Low-dose irradiation induced survival pathways, while high dose induced fibrotic pathways

In order to identify genes and pathways potentially involved in the cardiac response to irradiation, microarray and pathway analyses were performed using the software program IPA (a full list of gene expression levels after cardiac irradiation of $A p o E^{/-}$mice can be found at http://www. ebi.ac.uk/arrayexpress). Radiation significantly regulated 111 (2 Gy) and 169 (16 Gy) genes at 20 weeks, and 116 (2 Gy) and 158 (16 Gy) genes at 40 weeks.

Supplemental Figures I-IV show gene interaction networks of these radiationregulated genes. Known ingenuity functional and/or canonical pathway analysis (Supplemental Table II on page 161) was used to identify overrepresentation of radiation-correlated genes within known functional assignments (such as inflammatory response) and to generate hypotheses.

The most significant pathway for $2 \mathrm{~Gy}$ at 20 weeks (Supplemental Figure I on $\mathrm{p} \mathrm{162)}$ was involved in cellular growth and proliferation. Matrix metalloproteinase 2 (MMP2) was identified as a central molecule. Furthermore, genes within this pathway were also involved in the first canonical pathway 'circadian rhythm' (nervous system) and in maintenance of blood pressure and heart beat (aryl hydrocarbon receptor nuclear translocator like, ARNTL). Irradiation with 16 Gy at 20 weeks (Supplemental Figure II on page 163) resulted in a significant regulation in cell-to-cell signaling and interaction pathway, with tissue inhibitor of metalloproteinase 1 (TIMP1) and heme oxygenase 1 (HMOX1) as central genes; both genes were significantly upregulated. Moreover, the classical and alternative pathway of the complement system was negatively regulated after $16 \mathrm{~Gy}$. This operates within the cell-to-cell signaling and interaction pathway and was the first canonical pathway. Inflammatory response and inflammatory disease were also among the top biological functions altered after high-dose irradiation, including significant upregulation of Angiopoietin 2 (ANGPT2).

At 40 weeks after 2 Gy (Supplemental Figure III on page 164), cellular development associated network was significantly regulated. This includes cyclin dependent kinase inhibitor $1 \mathrm{~A}$ (CDKN1A) and a number of heat shock genes, with heat shock protein 70 (Hsp70) as central molecule. P13K/Akt signaling was the prominent canonical pathway. Irradiation with $16 \mathrm{~Gy}$ (Supplemental Figure IV on page 165) resulted in significant regulation in cell 
movement pathway at 40 weeks. The most pronounced molecules within this pathway are fibronectin-1 and collagen, indicating tissue injury. Moreover, fibrosis was the most upregulated canonical pathway including, connective tissue growth factor (CTGF), endothelin 1 (EDN1), fibronectin 1 (FN1) and platelet-derived growth factor (PDGF). Once again, inflammatory response and inflammatory disease were also among the top biological functions altered at 40 weeks after high-dose irradiation.

\section{Modest changes in cardiac function after irradiation}

Ultrasound measurements showed significant decreases in EDV and ESV, and an increase in EF at 20 weeks after 16 Gy (Supplemental Figure $\mathbf{V}$ on page 166). Gated-SPECT $\left.{ }^{99 \mathrm{~m}} \mathrm{Tc}-M y o v i e w\right)$ showed similar radiation-induced decreases in EDV and ESV. However, these parameters are all within normal ranges and are not indicative of severe cardiac dysfunction.

\section{Discussion}

In this study the effect of local cardiac irradiation on heart structure and function, and the development of coronary atherosclerotic lesions, was investigated in hypercholesterolemic $A p o E^{-/}$mice. Compared to previously examined C57BL/6j mice ${ }^{8}$, which do not develop atherosclerosis, radiationinduced inflammatory changes in the myocardium of $A p o E^{-1}$ mice were similar, although the baseline level of inflammation in $A p o E^{-/}$mice was higher, as expected $^{13}$. Pathway analyses also indicated a stimulated inflammatory response at 20 and 40 weeks after $16 \mathrm{~Gy}$. This included upregulation of ANGPT2, which is increased in endothelial cells after tissue injury and stimulates an aggressive fibrotic response. ${ }^{14}$ Furthermore, 16 Gy regulated cellto-cell signaling and interaction pathway of which TIMP1 is a central gene. TIMP1 levels are correlated with myocardial hypertrophy, fibrosis and diastolic dysfunction. ${ }^{15}$ Moreover, the complement system pathway was negatively regulated after $16 \mathrm{~Gy}$, whereas activation of the pathway results in beneficial effects in immune defense. ${ }^{16}$ In contrast, 2 Gy triggered a survival response, presumably in an attempt to stimulate recovery, by regulating the pathway of cellular growth and proliferation (20 weeks) and cellular development (40 
weeks). Hsp and MMP2 are known to be involved in these pathways and play a crucial role in cardiomyocyte protection. ${ }^{17,}{ }^{18} \mathrm{Hsp} 70$ can protect from stressinduced injury by inhibiting Fas-mediated apoptosis. Another central molecule of the cellular development pathway is CDKN1A, which is known to play a role in stress response and repair of DNA damage. ${ }^{19}$

On the other hand, high-dose irradiation induced fibrotic pathways. Diffuse interstitial fibrosis is one of the morphological hallmarks of radiationinduced myocardial injury. ${ }^{20,21}$ An increase in interstitial collagen content with dose was found in the myocardium of $A p o E^{\prime-}$ mice at 20 and 40 weeks after irradiation, which was not observed until 40 weeks after irradiation of C57BL/6j mice ${ }^{8}$. Microarray pathway analysis also showed highly upregulated collagen pathway in $\mathrm{ApoE}^{--}$mice after $16 \mathrm{~Gy}$, which was not observed in C57BL/6j mice (data shown at http://www.ebi.ac.uk/arrayexpress). This could eventually lead to a more serious increase in cardiac fibrosis at later timepoints.

In previous studies ${ }^{9,10}$, we investigated the effect of local irradiation on the progression of atherosclerosis in the carotid arteries of $\mathrm{ApoE}^{--}$mice and observed an accelerated development of inflammatory plaques. In addition, the present study shows an accelerated development, independently from valvular lesions, of atherosclerotic lesions in the coronary arteries after radiotherapy. High-dose irradiation significantly increased the number of coronary lesions at 20 weeks FU (in mice aged 30 weeks), while age-related atherosclerosis in these coronary arteries is mostly observed at 60 weeks of age in $\mathrm{ApoE}^{-1}$ mice. ${ }^{11}$ In addition, the coronary lesions in irradiated hearts contained much larger necrotic cores, indicative of a more advanced phenotype.

Radiation has been shown to increase the permeability of endothelial cells by induction of inflammatory and thrombotic pathways ${ }^{22,23}$, including increased production and release of VWF. The increase in VWF deposition in the irradiated heart observed in this study is also indicative of thrombotic endothelial cell damage. ${ }^{21}$ This could increase vascular permeability and, combined with hypercholesterolemia, lead to lipid accumulation, thus stimulating atherogenesis. Furthermore, at 20 weeks $16 \mathrm{~Gy}$ irradiation regulated genes that are associated with severe and persistent endothelial damage, but prevent intravascular thrombosis (e.g. HMOX124). Irradiated 
$A p o E^{\prime-}$ hearts also showed microvascular damage, indicated by a loss of microvessels and a decreased activity of endothelial ALP in the remaining vessels. Decreased ALP activity was already observed at 20 weeks after $2 \mathrm{~Gy}$ in $A p o E^{\prime-}$ mice, whereas there was no decrease in MVD after this dose. Decreases in ALP were only found after higher doses in C57BL/6j mice ${ }^{8}$, suggesting that hypercholesterolemia accelerated the response. An increase in the presence of iron-containing macrophages, as a sign of vascular damage and bleeding, was found in the myocardium of irradiated mice and was associated with an increased deposition of albumin at 40 weeks after high-dose irradiation. These results indicate that $A p o E^{\prime-}$ mice are susceptible to both macrovascular and microvascular damage. In addition, high-dose irradiation caused an increased permeability of the endocardium, leading to leakage of fibrin at 40 weeks.

Irradiation of $\mathrm{ApOE}^{/-}$mice modestly affected cardiac function at 20 weeks FU, similar to C57BL/6j mice ${ }^{8}$. However, 16 Gy lead to sudden death of C57BL/6j mice before 40 weeks $\mathrm{FU}$, while $A p o E^{\prime-}$ mice survived until 40 weeks after local high-dose irradiation. The high mortality rate observed in C57BL/6j mice was probably due to the prominent deposition of amyloid in the myocardium caused by vascular leakage, leading to the inability to compensate for the structural damage and to maintain cardiac function. Since ApoE itself is one of the components of amyloid ${ }^{25}$, irradiated $A p o E^{-1-}$ mice showed no signs of cardiac amyloidosis, although there was evidence of vascular leakage. The fact that we did not observe a decreased survival in the irradiated $\mathrm{ApoE}^{-\mathrm{r}}$ mice, despite more pronounced microvascular damage and a similar reduction in cardiac function, suggests that the amyloid deposits played a detrimental role in cardiac integrity and led to the high mortality rate of the irradiated C57BL/6j mice.

In C57BL/6j mice, inflammatory changes were mainly observed in the epicardium ${ }^{8}$, while $A_{p o E^{-}}$mice showed endocardial damage with foam cell accumulations at 20 weeks after $16 \mathrm{~Gy}$ and collagen deposits at 40 weeks. Endocardial foam cell accumulation was previously described in diabetes, hyperlipidemic diseases and congenital diseases, whereby the endocardium is subjected to atherosclerotic events similar to those in lesion-prone sites such as aortic valves and bifurcations of large arteries. ${ }^{26,27}$ It is possible that, 20 weeks after irradiation, the underlying damaged inflammatory myocardium 
attracted macrophages to the endocardium, which transform into foam cells in the presence of hyperlipidemia.

In conclusion, the combination of irradiation and hypercholesterolemia led to an early and pronounced inflammatory response and microvascular leakage in the hearts of $\mathrm{ApOE}^{-/}$mice. In addition, the progression of atherosclerosis in the coronary arteries was clearly accelerated after high-dose local irradiation of the heart, combined with foam cell deposits in the endocardium. Despite these pronounced effects on cardiac structure and increased development of coronary atherosclerosis, the mice were able to maintain cardiac function up to 40 weeks after irradiation. 


\section{Supplemental data}

Supplemental Table I. Body and organ weights of mice at sacrifice.

\begin{tabular}{lcccc}
\hline Treatment & Body weight $(\mathbf{g})$ & Heart weight $(\mathbf{g})$ & Lung weight $(\mathbf{g})$ & Heart/body weight \% \\
\hline $\mathbf{2 0}$ weeks FU & & & & \\
0 Gy & $32.3 \pm 0.6$ & $0.21 \pm 0.006$ & $0.17 \pm 0.003$ & $6.7 \pm 0.2$ \\
2 Gy & $32.5 \pm 0.3$ & $0.20 \pm 0.005$ & $0.17 \pm 0.003$ & $6.0 \pm 0.1$ \\
$\mathbf{8}$ Gy & $32.1 \pm 0.9$ & $0.22 \pm 0.013$ & $0.17 \pm 0.006$ & $6.7 \pm 0.4$ \\
16 Gy & $30.9 \pm 0.5$ & $0.21 \pm 0.007$ & $0.17 \pm 0.002$ & $6.7 \pm 0.2$ \\
40 weeks FU & & & & \\
0 Gy & $33.2 \pm 0.8$ & $0.20 \pm 0.006$ & $0.17 \pm 0.004$ & $6.0 \pm 0.1$ \\
2 Gy & $32.5 \pm 1.0$ & $0.21 \pm 0.009$ & $0.17 \pm 0.004$ & $6.3 \pm 0.3$ \\
8 Gy & $34.5 \pm 1.1$ & $0.21 \pm 0.005$ & $0.18 \pm 0.004$ & $6.1 \pm 0.2$ \\
16 Gy & $34.1 \pm 0.8$ & $0.23 \pm 0.006^{*}$ & $0.21 \pm 0.011^{*}$ & $6.9 \pm 0.2^{*}$
\end{tabular}

Values represent mean \pm SEM. $* \mathrm{P}<0.05$ compared to age-matched controls.

Supplemental Table II. Top first pathway and significant canonical pathways (limited to three) analyzed in Ingenuity Pathway Analysis (IPA) at 20 and 40 weeks after 2 and 16 Gy. IPA score represents the likelihood (decreases with a score $>2$ ) that the set of focus genes in a pathway could be explained by random chance alone.

\begin{tabular}{|c|c|c|c|}
\hline & Pathway & IPA score & Canonical pathway \\
\hline \multicolumn{4}{|c|}{20 weeks FU } \\
\hline 2 Gy & $\begin{array}{l}\text { Cellular growth and } \\
\text { proliferation }\end{array}$ & 49 & 1. Circadian rhythm signaling \\
\hline \multirow[t]{2}{*}{$16 \mathrm{~Gy}$} & Cell-To-Cell signaling & 45 & 1. Complement system \\
\hline & & & $\begin{array}{l}\text { 2. Fibrosis } \\
\text { 3. Acute phase response signaling }\end{array}$ \\
\hline \multicolumn{4}{|c|}{40 weeks FU } \\
\hline 2 Gy & Cellular development & 46 & ND \\
\hline $16 \mathrm{~Gy}$ & Cellular movement & 35 & 1. Fibrosis \\
\hline
\end{tabular}

ND means not detected. 


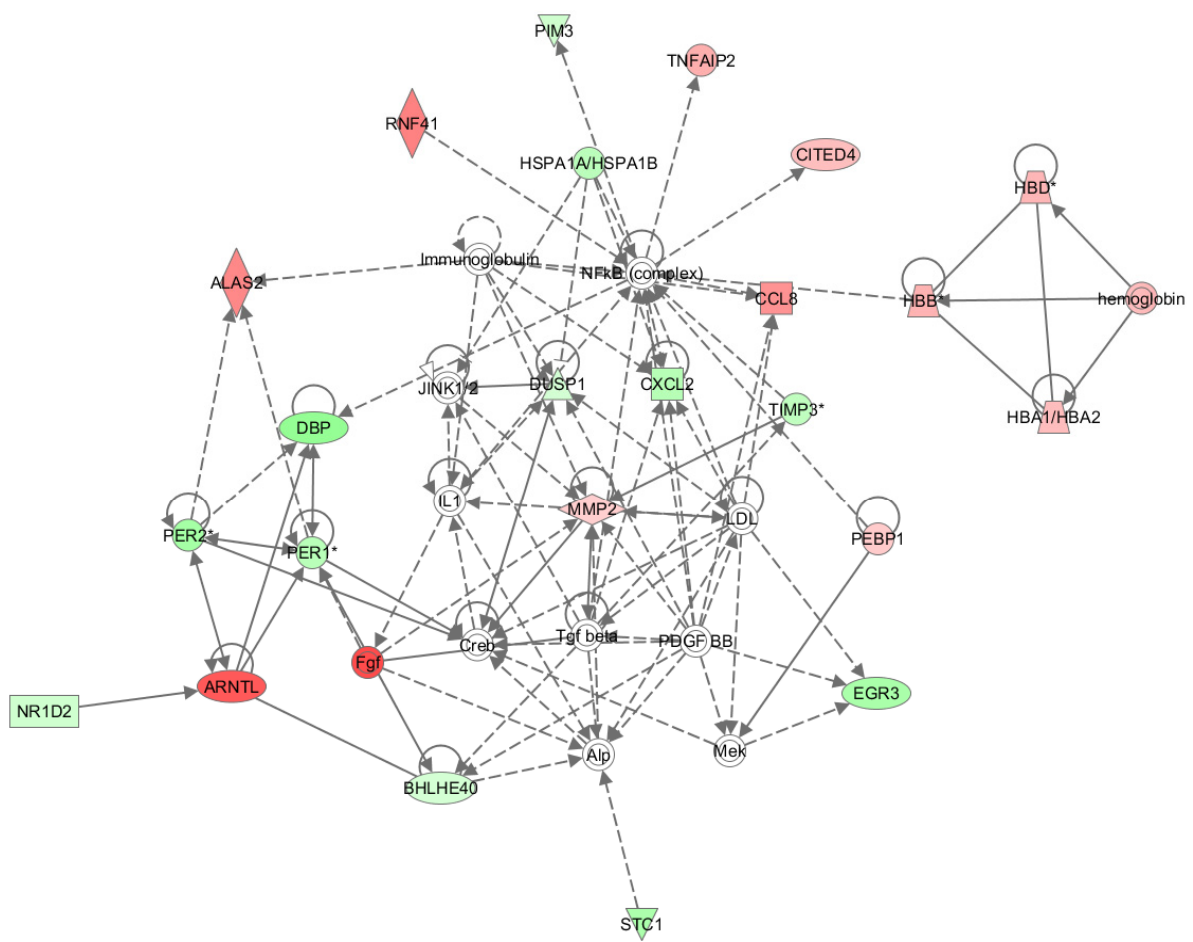

Supplemental Figure I. Gene interaction network of $2 \mathrm{~Gy}$ irradiation-correlated genes at 20 weeks, generated using IPA. Genes are represented as nodes. Solid lines represent a direct relationship and dashed lines represent an indirect relationship. Node color represents the correlation of expression level with irradiation and color intensity indicates the degree of correlation (red means a positive correlation, while green means a negative correlation). 


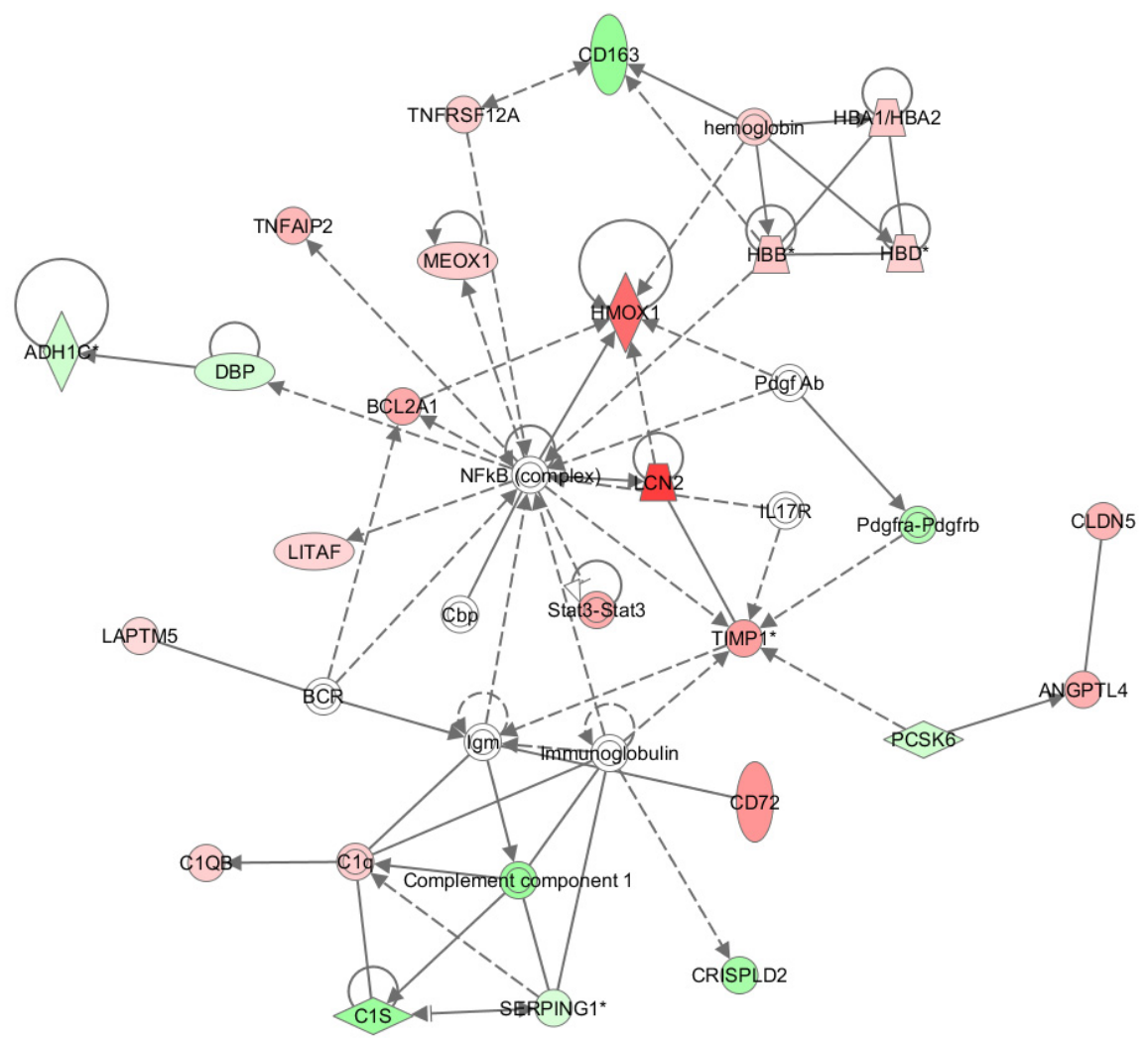

일 2000-2012 Ingenuity Systems, Inc. All rights reserved.

Supplemental Figure II. Gene interaction network of $16 \mathrm{~Gy}$ irradiation-correlated genes at 20 weeks, generated using IPA. Genes are represented as nodes. Solid lines represent a direct relationship and dashed lines represent an indirect relationship. Node color represents the correlation of expression level with irradiation and color intensity indicates the degree of correlation (red means a positive correlation, while green means a negative correlation). 


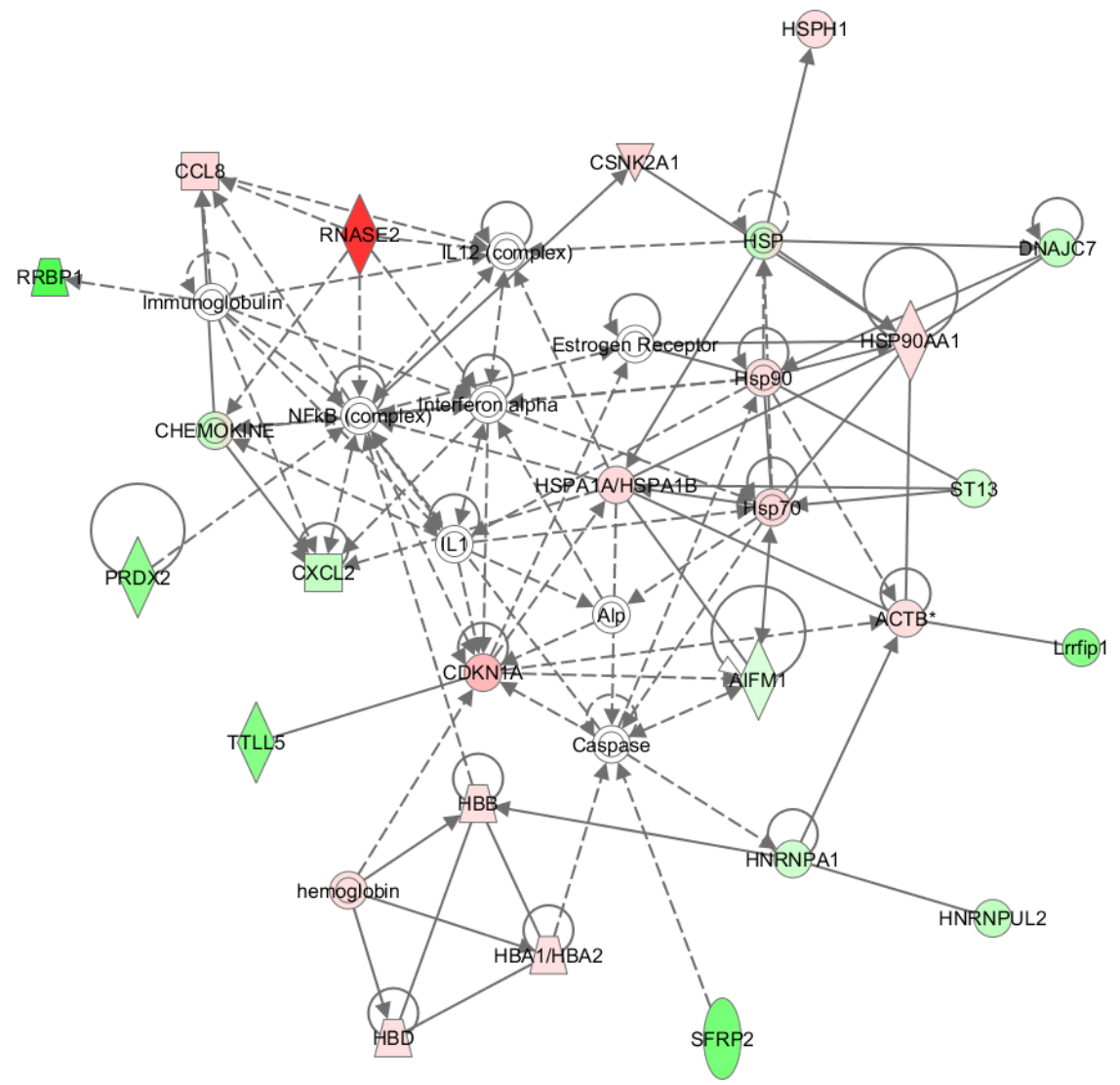

(ㄷ) 2000-2012 Ingenuity Systems, Inc. All rights reserved.

Supplemental Figure III. Gene interaction network of $2 \mathrm{~Gy}$ irradiation-correlated genes at 40 weeks, generated using IPA. Genes are represented as nodes. Solid lines represent a direct relationship and dashed lines represent an indirect relationship. Node color represents the correlation of expression level with irradiation and color intensity indicates the degree of correlation (red means a positive correlation, while green means a negative correlation). 


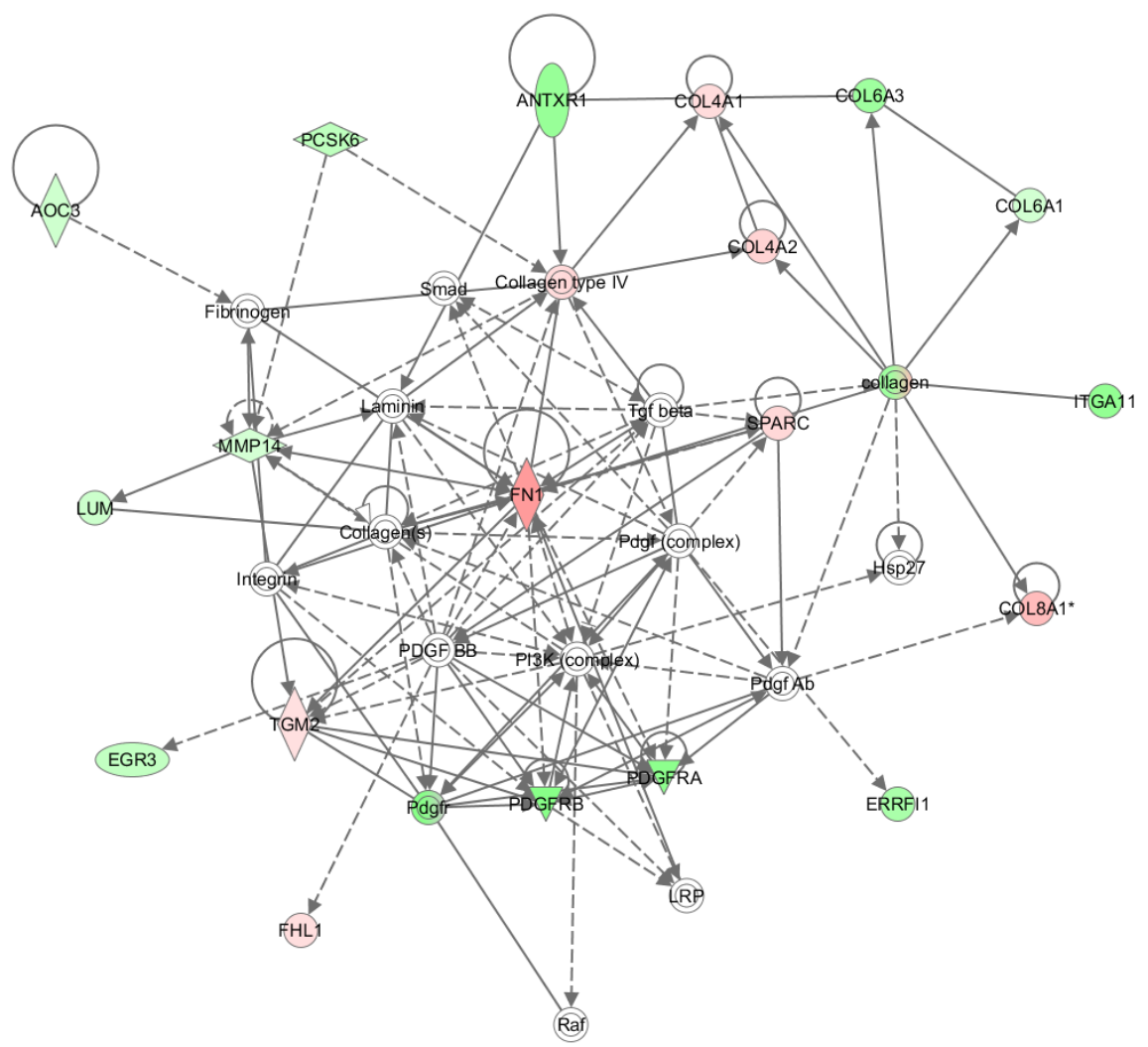

( $2000-2012$ Ingenuity Systems, Inc. All rights reserved

Supplemental Figure IV. Gene interaction network of $16 \mathrm{~Gy}$ irradiation-correlated genes at 40 weeks, generated using IPA. Genes are represented as nodes. Solid lines represent a direct relationship and dashed lines represent an indirect relationship. Node color represents the correlation of expression level with irradiation and color intensity indicates the degree of correlation (red means a positive correlation, while green means a negative correlation). 
A

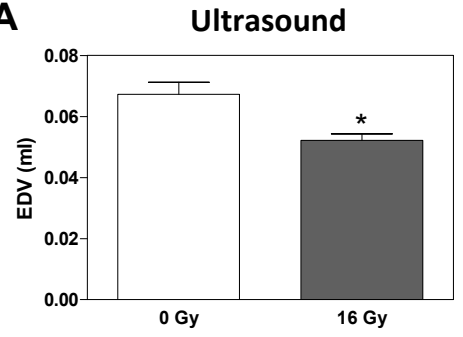

B

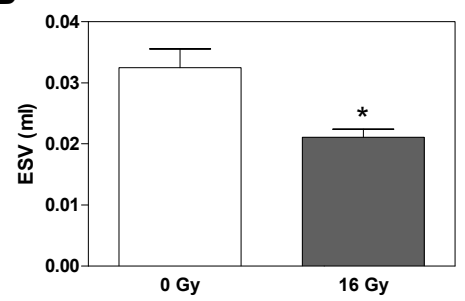

C

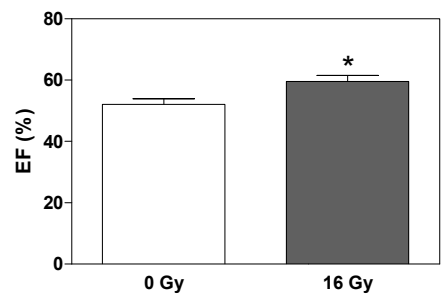

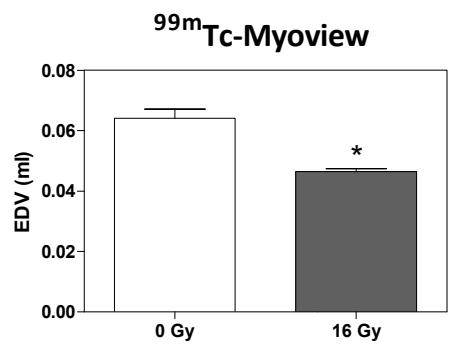
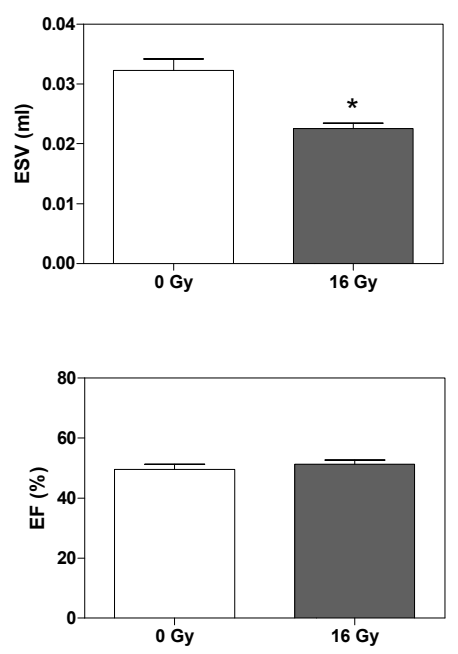

Supplemental Figure V. Ultrasound and myoview (gated SPECT/CT) measurements of (A) EDV, (B) ESV and (C) EF for control and 16 Gy irradiated mice at 20 weeks FU. Bars represent mean \pm SEM. * $\mathrm{P}<0.05$ compared to age-matched controls. 


\section{References}

1. Gyenes G, Rutqvist LE, Liedberg A, et al. Long-term cardiac morbidity and mortality in a randomized trial of pre- and postoperative radiation therapy versus surgery alone in primary breast cancer. Radiother Oncol 1998; 48: 185-190.

2. Aleman BM, van den Belt-Dusebout AW, Klokman WJ, et al. Long-term cause-specific mortality of patients treated for Hodgkin's disease. J Clin Oncol 2003; 21: 3431-3439.

3. Adams MJ, Hardenbergh PH, Constine LS, et al. Radiation-associated cardiovascular disease. Crit Rev Oncol Hematol 2003; 45: 55-75.

4. McGale $P$, Darby SC, Hall $P$, et al. Incidence of heart disease in 35,000 women treated with radiotherapy for breast cancer in Denmark and Sweden. Radiother Oncol 2011; 100: 167-175.

5. Schultz-Hector S, Trott KR. Radiation-induced cardiovascular diseases: is the epidemiologic evidence compatible with the radiobiologic data? Int J Radiat Oncol Biol Phys 2007; 67: 10-18.

6. Darby SC, Cutter DJ, Boerma M, et al. Radiation-related heart disease: current knowledge and future prospects. Int J Radiat Oncol Biol Phys 2010; 76: 656-665.

7. Andratschke N, Maurer J, Molls $M$, et al. Late radiation-induced heart disease after radiotherapy. Clinical importance, radiobiological mechanisms and strategies of prevention. Radiother Oncol 2011; 100: 160-166.

8. Seemann I, Gabriels K, Visser NL, et al. Irradiation induced modest changes in murine cardiac function despite progressive structural damage to the myocardium and microvasculature. Radiother Oncol 2012; 103: 143-150.

9. Hoving S, Heeneman S, Gijbels MJ, et al. Single-dose and fractionated irradiation promote initiation and progression of atherosclerosis and induce an inflammatory plaque phenotype in ApoE(-/-) mice. Int J Radiat Oncol Biol Phys 2008; 71: 848-857.

10. Stewart FA, Heeneman S, Te Poele J, et al. Ionizing radiation accelerates the development of atherosclerotic lesions in ApoE-/- mice and predisposes to an inflammatory plaque phenotype prone to hemorrhage. Am J Pathol 2006; 168: 649658.

11. Hu W, Polinsky P, Sadoun E, et al. Atherosclerotic lesions in the common coronary arteries of ApoE knockout mice. Cardiovasc Pathol 2005; 14: 120-125.

12. Du P, Kibbe WA, Lin SM. lumi: a pipeline for processing Illumina microarray. Bioinformatics 2008; 24: 1547-1548.

13. Tenger $C$, Zhou X. Apolipoprotein E modulates immune activation by acting on the antigen-presenting cell. Immunology 2003; 109: 392-397.

14. Jeansson M, Gawlik A, Anderson G, et al. Angiopoietin-1 is essential in mouse vasculature during development and in response to injury. The Journal of clinical investigation 2011; 121: 2278-2289.

15. Moore L, Fan D, Basu R, et al. Tissue inhibitor of metalloproteinases (TIMPs) in heart failure. Heart failure reviews 2012; 17: 693-706.

16. Yasuda $M$, Takeuchi $K$, Hiruma $M$, et al. The complement system in ischemic heart disease. Circulation 1990; 81: 156-163.

17. Zhao Y, Wang W, Qian L. Hsp70 may protect cardiomyocytes from stress-induced injury by inhibiting Fas-mediated apoptosis. Cell stress \& chaperones 2007; 12: 83-95.

18. Matsusaka H, Ikeuchi M, Matsushima S, et al. Selective disruption of MMP-2 gene exacerbates myocardial inflammation and dysfunction in mice with cytokine-induced cardiomyopathy. American journal of physiology Heart and circulatory physiology 2005; 289: H1858-1864. 
19. Bendjennat $M$, Boulaire J, Jascur $T$, et al. UV irradiation triggers ubiquitin-dependent degradation of p21(WAF1) to promote DNA repair. Cell 2003; 114: 599-610.

20. Kruse JJ, Zurcher C, Strootman EG, et al. Structural changes in the auricles of the rat heart after local ionizing irradiation. Radiother Oncol 2001; 58: 303-311.

21. Boerma $\mathrm{M}$, Kruse JJ, van Loenen $\mathrm{M}$, et al. Increased deposition of von Willebrand factor in the rat heart after local ionizing irradiation. Strahlentherapie und Onkologie : Organ der Deutschen Rontgengesellschaft et al. 2004; 180: 109-116.

22. Konings AW, Smit Sibinga CT, Aarnoudse MW, et al. Initial events in radiation-induced atheromatosis. II. Damage to intimal cells. Strahlentherapie 1978; 154: 795-800.

23. van Kleef $E$, Verheij $M$, te Poele $H$, et al. In vitro and in vivo expression of endothelial von Willebrand factor and leukocyte accumulation after fractionated irradiation. Radiation research 2000; 154: 375-381.

24. True AL, Olive $\mathrm{M}$, Boehm $\mathrm{M}$, et al. Heme oxygenase-1 deficiency accelerates formation of arterial thrombosis through oxidative damage to the endothelium, which is rescued by inhaled carbon monoxide. Circulation research 2007; 101: 893-901.

25. Sawabe M, Hamamatsu A, Ito $\mathrm{T}$, et al. Early pathogenesis of cardiac amyloid deposition in senile systemic amyloidosis: close relationship between amyloid deposits and the basement membranes of myocardial cells. Virchows Archiv : an international journal of pathology 2003; 442: 252-257.

26. Stehbens WE, Delahunt B, Zuccollo JM. The histopathology of endocardial sclerosis. Cardiovasc Pathol 2000; 9: 161-173.

27. Popov D, Sima A, Stern D, et al. The pathomorphological alterations of endocardial endothelium in experimental diabetes and diabetes associated with hyperlipidemia. Acta Diabetol 1996; 33: 41-47. 


The hypotheses underlying this thesis were that the dosage of calcineurinNFAT-dependent immunosuppression is critical in protecting against inflammation-driven atherosclerosis, and that radiotherapy increases the risk for late cardiovascular diseases (CVD) via stimulating inflammation-induced vascular and cardiac damage. Therefore, we aimed to unravel dose-dependent mechanisms of the immunosuppressive drug FK506 on atherosclerosis (chapter 2), to investigate the therapeutic potential of blocking NFATC2, a target of FK506, in atherosclerosis (chapter 3), to determine the effect of irradiation on existing plaque progression and inflammatory responses (chapter 4), and to evaluate the dose and time dependence of structural and functional cardiovascular damage after heart irradiation in wild-type (chapter 5) and hypercholesterolemic (chapter 6) mice.

\section{Immunosuppressive therapy in atherosclerosis}

Transcription factors of the nuclear factor of activated T-cell (NFAT) family have crucial roles in the development and function of the immune system and are tightly regulated by calcineurin and NFAT kinases. NFAT has been considered as a target for therapeutic approaches that are aimed at regulating immune responses, like in the treatment of graft transplant rejection. We explored the therapeutic potential of immunsuppressive FK506 (tacrolimus), a calcineurin-NFAT signaling inhibitor, in protecting against atherosclerosis. We clearly indicated FK506 dosage as a determinant of the effect of FK506 on murine atherosclerosis and risk for developing severe complications.

FK506 is a widely used immunosuppressive drug that inhibits the calcineurin-NFAT signaling pathway, responsible for amongst others activation of T-cell immune responses. Nevertheless, high-dose, long-term use of FK506 in transplant recipients is associated with severe inflammatory complications, such as CVD, due to hyperlipidemia and hypertension. ${ }^{1}$ This was confirmed by experimental studies reporting that high-dose FK506 treatment exacerbated atherosclerosis ${ }^{2}$, whereas we have previously shown that low-dose FK506 treatment attenuated the progression of atherosclerosis and improved plaque stability in apolipoprotein E-knockout $\left(A p O E^{\prime}\right)$ mice without affecting plasma lipid levels or systemic parameters ${ }^{3}$. In chapter $\mathbf{2}$, we were able to address this paradox, showing a dose-dependent effect of FK506 on macrophage polarization and cholesterol levels. Low-dose FK506 treatment protected 
against atherosclerosis by favoring anti-inflammatory $\mathrm{M} 2$ macrophage polarization, whereas high-dose FK506 did not result in atheroprotection due to absent M2 skewing and increased cholesterol levels.

The dose-dependent effect of FK506 on macrophage inflammatory status can be explained by the fact that NFAT family members NFAT1(C2), NFAT2(C1), NFAT4(C3) (activated by intracellular $\mathrm{Ca}^{2+}$ signaling) and NFAT5 (activated in response to osmotic stress) are co-expressed in diverse cell types of the immune system ${ }^{4}$. NFATC1, C2 and C3 isoforms are identified as major transcriptional regulators in naïve T-cells and differentiated effector T-cells, as well as in T-cell anergy and regulatory T-cells (Treg), and high-dose FK506 has been shown to induce a shift towards $\mathrm{Th}_{2}$-immune responses. Recently, it has become apparent that NFAT transcription factors also play a role in various other cells of the haematopoietic system, such as macrophages (NFAT5 regulates expression of Toll-like receptor (TLR)-induced genes and macrophage migration) ${ }^{5,6}$, dendritic cells (NFATC2 regulates life cycle and dectin-1 activated gene expression) ${ }^{7,8}$, mast cells (NFATC1 and C2 regulate hypoxia-inducible factor $1 \alpha($ HIF1 $\alpha)$, interleukin (IL)-13, tumor necrosis factor $\alpha$ (TNF $\alpha)$ and prosurvival protein $\mathrm{A} 1$ gene transcription) ${ }^{9-11}$ and B-cells (NFATC1 regulates CD5 expression) ${ }^{12-15}$. In addition, we identified a possible role of NFAT proteins in macrophage polarization, as low-dose FK506 treatment induced a M2 macrophage polarization (chapter $\mathbf{2}$ ).

In an attempt to pinpoint the target of FK506 atherogenic activity, we further investigated the impact of deficiency of one candidate target of FK506, NFATC2, on atherosclerosis (chapter 3). NFATC2 is known to induce $\mathrm{Th}_{1^{-}}$ immune responses, but surprisingly NFATC2 deficiency aggravated rather than protected against atherosclerotic plaque formation despite $\mathrm{Th}_{2}$ skewing. The increased atherosclerosis was due to an augmented proliferative activity and effector/memory phenotype of T-cells, more prone to migrate to the atherosclerotic lesion. Cell-specific differences in the expression of NFAT proteins or the ability to differentially interact with lineage-specific coactivators and interact with a given promoter domain during T-cell activation or differentiation might explain why opposite T-cell responses and functions were found in mice deficient in specific NFAT isoforms (Table 1). ${ }^{16-29}$ In contrast to NFATC2 deficiency, T-cells deficient in NFATC1 had impaired production of $\mathrm{Th}_{2}$-related cytokines and NFATC3 deficiency resulted in a mild hyperactivation 
of peripheral T-cells. Interestingly, NFATC2 has been shown to bind to both interferon- $\gamma$ (IFN- $\gamma$ ) and IL-4 promoters in activated $\mathrm{Th}_{1^{-}}$and $\mathrm{Th}_{2}$-cells respectively ${ }^{30}$, thus both NFATC1 and C2 are positive regulators of IL-4 gene transcription. ${ }^{24,31}$ This indicates that NFAT proteins not only are functionally redundant in orchestrating $\mathrm{Th}_{2}$-responses, but also can modulate both branches of T-cell differentiation. Furthermore, Ranger et al. showed that the absence of NFATC2 and NFATC3 led to the continuous import of NFATC1 into the nucleus upon T-cell activation to induce IL-4 expression, resulting in an enhanced $\mathrm{Th}_{2}$-immune response. ${ }^{28}$ Thus, selective inhibition of NFAT isoforms can induce compensatory activation of other NFAT-family members forming nuclear homo- or heterodimers, responsible for unexpected immune responses. The balance between NFAT-family members and co-stimulatory transcription factors is therefore decisive in the coordinated transcriptional regulation of immune responses.

Table 1. NFAT-deficient mice. Adapted from Macian ${ }^{4}$.

\begin{tabular}{|c|c|c|}
\hline NFAT protein & Phenotype in the immune system & References \\
\hline NFAT1(C2) & $\begin{array}{l}\text { Moderate hyperproliferation with splenomegaly. } \\
\text { Moderately enhanced B- and T-cell responses, with } \\
\text { bias towards Th2-cell responses. Prolonged IL-4 } \\
\text { expression and decreased IFN-Y production in } \\
\text { response to TCR ligation. Increased Th17 response } \\
\text { with NFAT1 hyperactivation. }\end{array}$ & $16-21$ \\
\hline NFAT2(C1) & $\begin{array}{l}\text { In the RAG2-deficient complementation system, } \\
\text { reduced proliferative responses by T-cells. Impaired } \\
\text { repopulation of the thymus and lymphoid organs. } \\
\text { Impaired Th2-cell responses and IL-4 production. }\end{array}$ & $22-24$ \\
\hline $\begin{array}{l}\text { NFAT1(C2) and } \\
\text { NFAT2(C1) }\end{array}$ & $\begin{array}{l}\text { In fetal liver chimeras, grossly impaired T-cell } \\
\text { effector functions, with profound defects in cytokine } \\
\text { production and cytolytic activity. B-cell hyperactivity. }\end{array}$ & 25 \\
\hline NFAT4(C3) & $\begin{array}{l}\text { Impaired development of CD4 and CD8 single-positive } \\
\text { cells, with increased apoptosis of double-positive } \\
\text { thymocytes. Mild hyperactivation of peripheral T-cells. }\end{array}$ & 26 \\
\hline $\begin{array}{l}\text { NFAT1(C2) and } \\
\text { NFAT4(C3) }\end{array}$ & $\begin{array}{l}\text { TCR hyper-reactivity, with profound lymphopro- } \\
\text { liferative disorder. Notable increase in Th2-cell } \\
\text { responses. Allergic blepharitis and interstitial } \\
\text { pneumonitis. }\end{array}$ & 27,28 \\
\hline NFAT5 & $\begin{array}{l}\text { Impaired T-cell function under hyperosmotic } \\
\text { conditions. Decreased cellularity of the thymus and } \\
\text { spleen. }\end{array}$ & 29 \\
\hline
\end{tabular}


Although $\mathrm{Th}_{2}$-responses were originally deemed atheroprotective ${ }^{32}$, NFATC2 deficiency induced a splenic $\mathrm{Th}_{2}$-differentiation of T-cell responses and decreased $T_{1}$-cytokine IFN- $\gamma$ production concomitant with enhanced atherosclerosis. This is in line with other experimental studies that showed a marked decrease in plaque development when the $\mathrm{Th}_{2}$-cytokine IL-4 was depleted. Davenport and Tipping found a significant reduction in plaque area in the root (at 30 weeks of age) and arch (at 45 weeks of age) of the aorta of IL$4^{-/} / / A p o E^{--}$mice compared to $A p o E^{-/}$mice. ${ }^{33}$ Chimeric low-density lipoprotein receptor $(L D L r)^{-/-}$mice with IL-4-deficient bone marrow also showed reduced atherosclerosis in the arch and thoracic regions of the aorta, but not in the aortic root. $^{34}$ Further support for a pro-atherogenic effect of IL-4 is provided by a study of George et al. using a model of accelerated fatty streak formation. ${ }^{35} \quad \mathrm{~L}-4^{\%}$ mice had significantly reduced fatty streak formation compared with wild-type C57BL/6J mice. On the other hand, exogenous administration of IL-4 had no effect on atherogenesis in $A p o E^{\prime-}$ mice fed a normal chow or high-fat diet. ${ }^{36}$ These data indicate that the role of the $\mathrm{Th}_{2}$ cytokine IL-4 in atherosclerosis development depends on the vascular site, disease stage and experimental model. In contrast, other $\mathrm{Th}_{2}$-cytokines (IL-5, IL-13 and IL-10) have been shown to exhibit overt and consistent antiatherogenic properties. ${ }^{37-39}$ Both high-dose FK506 treatment and NFATC2 deficiency induced $\mathrm{Th}_{2}$-immune responses, indicating that the pro-atherogenic effect of FK506 treatment could in part be determined by inhibition of NFATC2. Blocking NFATC2 transcriptional activity, and thereby inducing possible dominant IL-4-mediated pro-atherogenic responses, would therefore not be an ideal therapeutic option for atherosclerosis. Interestingly, in patients with psoriasis, a prototypic $\mathrm{Th}_{1}$-associated autoimmune disease, daily IL-4 treatment induced a pronounced skewing of intralesional cytokines towards a $\mathrm{Th}_{2}$ pattern and increased IL-4-producing T-cells in blood, resulting in markedly reduced symptoms of psoriasis. ${ }^{40}$

An alternative approach for NFAT inactivation can be achieved by targeting specific docking of calcineurin on NFAT proteins rather than blocking calcineurin phosphatase activity. Already in 1999, a small peptide was discovered by Aramburu et al. ${ }^{41}$, which was able to selectively inhibit calcineurin-NFAT interaction and subsequent cytokine expression without affecting other calcineurin-signaling pathways, thereby reducing unwanted 
side-effects. ${ }^{42-44}$ This small peptide, VIVIT, has been successfully used to prolong graft survival after pancreatic islet cell transplantation in mice ${ }^{44}$ and effectively targets inflammatory and smooth muscle cell (SMC) hyperplastic responses that underlie restenosis. ${ }^{45}$ It is therefore expected that VIVIT has a protective effect on atherosclerosis, but this has not yet been investigated. However, VIVIT has a low potency (i.e. low cellular uptake), limiting its direct clinical application, and displays a preference for NFATC2. It is therefore likely that less selective but more potent antagonists of the calcineurin-NFAT interaction are needed to coordinate inhibition of cytokine secretion and other immune cell functions regulated by NFAT (such as macrophage inflammatory status). Nevertheless, VIVIT is less toxic than FK506 (or cyclosporin A) and can lead to the development of novel immunomodulatory strategies for the treatment of atherosclerosis. In this respect, MCV1 was recently designed, which targets two separate calcineurin docking sites and selectively prevented NFAT dephosphorylation at a potency of almost 1000-fold higher than that of the parental peptide VIVIT, without blocking calcineurin-phosphatase activity (Figure 1). ${ }^{46}$ Another beneficial effect of MCV1 may be that MCV analogues are rather lipophilic, favoring cellular uptake, in contrast to highly hydrophilic VIVIT. Thus MCV1 is not only more potent than VIVIT, but also more selective than FK506 in inhibiting NFAT. Interestingly, whereas the effect on atherosclerosis is still unknown, neointima formation in a mouse model of restenosis was reduced by MCV1. ${ }^{46}$

Overall, a better characterization of the roles of individual NFAT proteins in regulating T-cells and other cells of the immune system, and their extent of overlap in function, is necessary for selecting the optimal target for developing NFAT-mediated immunosuppressive therapeutic approaches in atherosclerosis. Currently, partial inhibition of calcineurin-NFAT signaling by low-dose FK506 has been shown atheroprotective. However, selective prevention of calcineurin-NFAT interactions will circumvent possible unfavorable side-effects and is expected to be even more effective in the treatment of atherosclerosis. 


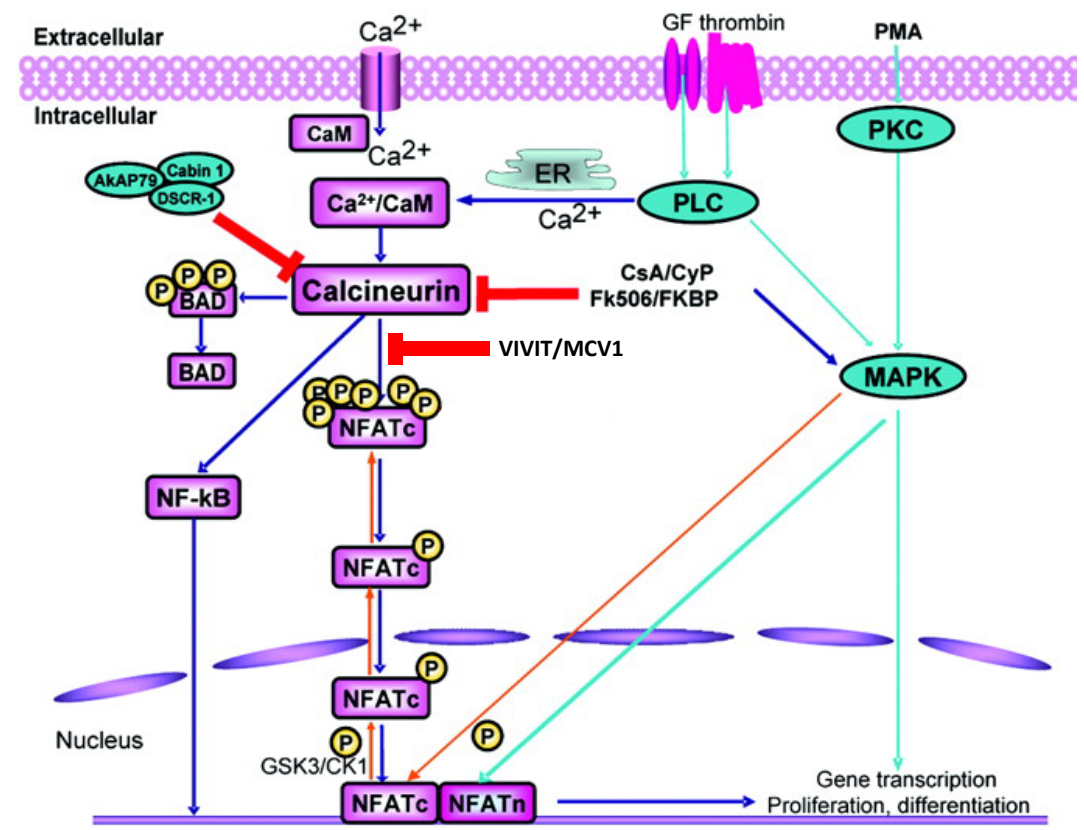

Figure 1. Presumed mode of action of cyclosporin A (CSA)/FK506 and VIVIT/MCV1 interference with NFAT activity. MCV1 selectively inhibits calcineurin-NFAT interactions, whereas CSA or FK506 disrupts the calcineurin phosphatase activity by binding to immunophilin CyP or FK506 binding protein (FKBP). Adapted from Yu et al. ${ }^{46}$ 


\section{Radiation-induced cardiovascular damage}

There is clear epidemiological evidence that thoracic radiotherapy increases the long-term risk for cardiovascular morbidity and mortality. However the pathogenesis of radiation-induced cardiotoxicity has not been studied in detail. In chapters 5 and 6, we reported dose-dependent progressive damage to the microvasculature after cardiac irradiation, indicated by a loss of microvessels, decreased endothelial alkaline phosphatase (ALP) activity as well as thrombotic endothelial cell (EC) damage (release of von Willebrand Factor (vWF)) in remaining microvessels, and vascular leakage. This could eventually lead to focal ischemia, myocardial cell death, inflammation, interstitial fibrosis, arrhythmias and heart failure. ${ }^{4-50}$ Permanent loss of ALP was evident after irradiation doses $\geq 2$ Gray (Gy), making this a particular sensitive marker of radiation-induced EC damage. Furthermore, we showed a transient increase in microvascular density at 20 weeks after irradiation of the heart of C57BL/6J mice with 2 and $8 \mathrm{~Gy}$. This was most probably due to stimulated proliferation in response to damage, a compensatory mechanism that was lost after higher irradiation dose (16 Gy) or at later times after lower doses. In keeping with these results, ECs isolated from irradiated murine hearts were recently reported to have an impaired angiogenic response. ${ }^{51}$ Moreover, after preoperative radiotherapy in the head and neck region, vascularization of the graft bed decreased as a function of the total dose and time after radiotherapy ${ }^{52}$, and free flap necrosis, due to loss of blood supply to the transferred tissue, occurred ${ }^{53}$.

In addition, we showed in chapter 6 that high-dose irradiation, in combination with hypercholesterolemia, accelerated atherosclerosis development with increased intraplaque necrosis in coronary arteries. Furthermore, radiation exposure to the neck region, including both carotid arteries and the aortic arch, of young ${ }^{54}$ mice as well as of old hypercholesterolemic mice with pre-existing atherosclerotic lesions (chapter 4) accelerated atherosclerosis and predisposed to the formation of highly inflammatory, macrophage-rich, thrombotic plaques. In these studies, a high single dose of radiation was used. Although fractionated doses would closer resemble clinical radiotherapy, a previous study by our group demonstrated that fractionation ( $20 \times 2 \mathrm{~Gy}$ ) resulted in a similar plaque phenotype compared to a single-dose treatment (14 Gy). ${ }^{55}$ In line with our findings after single-dose 
irradiation, $\mathrm{Yu}$ et al. recently showed that local radiation exposure of $A p o E^{-1}$ mice resulted in accelerated progression of advanced aortic root lesions, characterized by larger necrotic cores associated with increased numbers of apoptotic macrophages and reduced collagen content compared to shamtreated mice. ${ }^{56}$ Pakala et al. found atherosclerotic lesions in irradiated iliac arteries of hypercholesterolemic rabbits predominantly composed of macrophages expressing matrix metalloproteinases (MMPs). ${ }^{57}$ Interestingly, Virmani et al. reported severe luminal narrowing of pig coronary arteries at 6 months after radioactive stent placement. ${ }^{58}$

There is also epidemiological evidence of vascular damage among cancer survivors that received radiotherapy to the thorax or neck. In a recently published population-based case-control study of Darby et al., including 2168 women who underwent radiotherapy for breast cancer between 1958 and 2001, the mean cardiac dose was $4.9 \mathrm{~Gy}$. The risk of a major coronary event, defined as myocardial infarction, coronary revascularization or death from ischemic heart disease, increased linearly with the mean dose to the heart (7.4\%/Gy), and started to increase within the first 5 years after treatment to continue to be elevated for at least 20 years. ${ }^{59}$ Interestingly, the percentage increase in risk per Gy was higher when breast cancer was diagnosed at an age of 40 to 74 and patients were more likely suffering from subclinical age-related atherosclerosis (6.3-9.7\% increase/Gy), compared to an age of 20-39 years $(-1.5 \%$ increase/Gy). Moreover, the absolute increase in risk for a given cardiac dose was larger for women with pre-existing cardiac risk factors (e.g. history of ischemic heart disease or chronic obstructive pulmonary disease and smoking). Hancock et al. described coronary artery disease (CAD) among Hodgkin's lymphoma survivors treated with mediastinal radiation therapy. The relative risk of death from a myocardial infarction was 3.1 (95\% confidence interval (CI), 2.4-3.7), which progressively increased with time from treatment. ${ }^{60,61}$ Dorresteijn et al. showed an increased intima-media thickness (IMT) in carotid arteries of head and neck cancer patients treated with radiotherapy. ${ }^{62}$ Also an elevated risk for cerebrovascular diseases (stroke or transient ischemic attack) has been reported in survivors of head and neck cancer ${ }^{63-65}$ or Hodgkin's lymphoma, compared with the general population, and was related to largeartery atherosclerosis and cardio-embolisms. ${ }^{66,67}$ Additional recent studies among cancer survivors confirming radiotherapy as a risk factor for vascular 
injury and subsequent cardiac and cerebrovascular diseases are summarized in Table 2. ${ }^{68-78}$

Table 2. Selection of reported vascular studies among cancer survivors. Adapted from Mulrooney et al. ${ }^{79}$

\begin{tabular}{|c|c|c|}
\hline Study type & Major vascular findings & Reference \\
\hline Case series & $\begin{array}{l}\text { Acute carotid (common, internal, and external) } \\
\text { artery hemorrhage following radiotherapy, } \\
\text { fatal in } 4 \text { of } 10\end{array}$ & 68 \\
\hline Cross-sectional & $\begin{array}{l}\text { Total coronary artery calcium volume score higher } \\
\text { in survivors of Hodgkin's lymphoma with verified } \\
\text { coronary disease compared with those without } \\
\text { ( } 439 \text { vs. } 68, p=0.022 \text { ). }\end{array}$ & 69 \\
\hline Cross-sectional & $\begin{array}{l}\text { Carotid plaque present in } 18 \% \text { of pediatric cancer } \\
\text { survivors treated with neck irradiation vs } 2 \% \\
\text { controls }(p<0.001) \text {. Intima-media thickness (IMT) } \\
0.46 \text { mm } \pm 0.12 \text { in survivors vs. } 0.41 \mathrm{~mm} \pm 0.06 \\
\text { in controls }(p<0.001)\end{array}$ & 70 \\
\hline Retrospective cohort & $\begin{array}{l}7.4 \% \text { of Hodgkin's lymphoma survivors developed } \\
\text { carotid and/or subclavian artery disease at a median } \\
\text { of } 17 \text { years from treatment. } \\
\text { Observed-to-expected ratio for coronary bypass } \\
\text { surgery or percutaneous intervention } 1.6(95 \% \\
\mathrm{Cl}, 0.98-2.3)\end{array}$ & 71 \\
\hline Cross-sectional & $\begin{array}{l}\text { Significantly impaired endothelium-dependent } \\
\text { vasodilatation compared with contralateral, } \\
\text { non-irradiated arteries ( }-0.4 \pm 0.4 \text { vs. } 3.2 \pm 0.8 \%) \\
\text { in breast cancer survivors and compared with } \\
\text { healthy controls (-0.4 } \pm 0.4 \text { vs. } 2.5 \pm 0.6 \%), p<0.001\end{array}$ & 72 \\
\hline Cross-sectional & $\begin{array}{l}\text { Impaired endothelium-dependent relaxation } \\
\text { to acetylcholine }(33 \pm 6 \% \text { vs. } 100 \pm 4 \% \text {, } \\
p<0.001) \text { and } A 23187(65 \pm 8 \% \text { vs. } 98 \pm 4 \% \text {, } \\
p<0.01) \text { in human irradiated cervical arteries } \\
\text { compared with non-irradiated arteries. } \\
\text { No expression of endothelial nitric oxide } \\
\text { synthase on irradiated arteries }\end{array}$ & 73 \\
\hline Cross-sectional & $\begin{array}{l}\text { Increased IMT in irradiated carotid vessels compared } \\
\text { with non-irradiated controls }\end{array}$ & 74 \\
\hline Cross-sectional & $\begin{array}{l}\text { Intimal thickness was significantly increased in } \\
\text { irradiated vessels compared to unirradiated } \\
\text { arteries in head and neck cancer patients } \\
(0.173 \pm 0.113 \text { vs. } 0.118 \pm 0.065, p=0.018)\end{array}$ & 75 \\
\hline
\end{tabular}


Table 2. Continued.

\begin{tabular}{llr} 
Study type & Major vascular findings & Reference \\
Cross-sectional & $\begin{array}{l}\text { Larger IMT of the common carotid artery in post- } \\
\text { radiotherapy patients with head and neck malignancy } \\
\text { compared with matched healthy controls } \\
(0.74 \mathrm{~mm} \text { vs. } 0.46 \mathrm{~mm}, \mathrm{p}<0.001)\end{array}$ \\
Cross-sectional & $\begin{array}{l}\text { Irradiated stenotic carotid arteries showing greater } \\
\text { IMT }(0.96 \mathrm{~mm} \text { vs. } 0.80 \mathrm{~mm}, \mathrm{p}=0.008) \\
\text { and a narrower lumen }(5.5 \mathrm{~mm} \text { vs } 6.6 \mathrm{~mm}, \mathrm{p}<0.001)\end{array}$ \\
Cross-sectional & $\begin{array}{l}\text { Mean carotid IMT of patients treated with head and } \\
\text { neck irradiation was statistically greater than controls } \\
(2.2 \pm 1.5 \mathrm{~mm} \text { vs. } 0.7 \pm 0.15 \mathrm{~mm}, \mathrm{p}<0.05)\end{array}$ \\
\hline
\end{tabular}

\section{Potential mechanisms of radiation-induced atherosclerosis initiation}

The underlying mechanisms of radiation-induced atherosclerosis and cardiac damage, progressing subclinically over many years, are unknown and studies investigating the underlying pathogenesis of radiation-induced atherosclerosis in humans and mice are scarce. Since ECs are regarded as highly radiosensitive cells ${ }^{80}$, one possible mechanism is radiation-induced chronic endothelial damage or dysfunction. This may be explained by cumulative radiationinduced DNA injury or chronic oxidative stress by overproduction of reactive oxygen species (ROS) contributing to atherosclerosis. ${ }^{81}$ Endothelial damage following radiation has been observed by electron microscopy with swelling of the cytoplasm, formation of pseudopodia leading to luminal narrowing and detachment of ECs from the basal lamina ${ }^{82,83}$, which could lead to a reduction in the microvascular network and atherosclerotic plaque development in large arteries. This is supported by Halle et al. showing that genes in the nuclear factor kappa B (NFKB) pathway were expressed in arterial biopsies from irradiated vessels compared to unirradiated vessels in the same patients from 4 weeks to 9 years after treatment, suggesting chronic activation of proinflammatory pathways following radiation exposure. ${ }^{84}$ In addition, doses of more than 2 Gy increased endothelial inflammation and adhesiveness, triggering pro-atherogenic subendothelial accumulation of leukocytes. ${ }^{47,80,85,86}$ Further support for a vascular response to radiotherapy was provided by Sugihara et al. indicating, ex vivo, that nitric oxide (NO)-mediated endothelialdependent relaxation is impaired in human cervical arteries 4-6 weeks after radiotherapy. $^{73}$ 
Our group recently evaluated the in vivo expression of well-known endothelial adhesion (vascular (VCAM-1) and intercellular adhesion molecule-1 (ICAM-1)) and thrombotic molecules (thrombomodulin (TM) and tissue factor), pivotal in the initiation of atherosclerosis, short-term after a high local radiotherapeutic dose on the carotid arteries of $A p o E^{/-}$and C57BL/6J mice. ${ }^{87}$ As early as 4 weeks after $14 \mathrm{~Gy}$, a significant increase in the number of fatty streaks was observed compared to non-irradiated $A p o E^{/-}$mice, while none of the $\mathrm{C} 57 \mathrm{BL} / 6 \mathrm{~J}$ mice developed atherosclerotic lesions. Although prothrombotic pathways (governed by TM and tissue factor) were induced in irradiated carotid arteries of $\mathrm{ApoE}^{\prime-}$ mice only, early changes in expression of endothelial adhesion molecules (atheroprotective decrease in VCAM-1, no difference in ICAM-1) did not correlate with the increased fatty streak formation. Recently, Khaled et al. reported that irradiation can indeed change the adhesiveness of inflamed vascular endothelium via a chemokine-dependent activation of leukocyte integrins, establishing firm adhesion, even in the absence of increased expression of adhesion molecules. ${ }^{88}$ This highlights the need for further identification of the chemokines that are responsible for radiationinduced increased endothelial adhesiveness. On the other hand, irradiation of microvascular or tumor ECs enhanced expression of EC adhesion molecules (such as ICAM-1, VCAM-1, platelet endothelial cell adhesion molecule-1 (PECAM-1) and P-selectin) and decreased endothelial thrombo-resistance by loss of TM and increased expression of tissue factor. ${ }^{89-96}$ Jelonek et al. recently isolated mouse primary cardiac ECs and found an upregulated expression of VCAM-1 and E-selectin after in vitro and local heart irradiation. ${ }^{97}$ These data suggest that ECs lining large arteries respond differently to irradiation than ECs in small vessels and that genetic and site-specific differences in response to radiotherapy should be taken into account. Depending on the site of irradiation, radiotherapy may therefore result in different clinical manifestations making it more challenging to develop specific interventions.

In our studies, radiation-induced atherosclerosis was present in both larger elastic (carotid, aortic arch) and coronary arteries. In hypercholesterolemic mice, we found evidence of additional cardiac damage, i.e. lipid-laden macrophages (foam cells) and erythrocyte accumulation in the subendocardial layer (chapter 6), as well as in vessel-like structures with thin walls and absent elastic laminae (Figure 2). It remains to be determined 
whether these thin-walled vessels are cardiac venules, lymph vessels or telangiectatic capillaries, i.e. abnormal, dilated vessels prone to rupture, although the latter has not been described in the heart. Of note, Hoving et al. recently observed a decrease in pericyte coverage after murine cardiac irradiation with $16 \mathrm{~Gy}$, contributing to blood vessel instability. ${ }^{98}$ In breast cancer patients, the incidence of telangiectasia progressively increased in irradiated skin from 1 to 10 years after radiotherapy. ${ }^{99,} 100$ These signs are suggestive of broader radiation-induced endothelial damage.

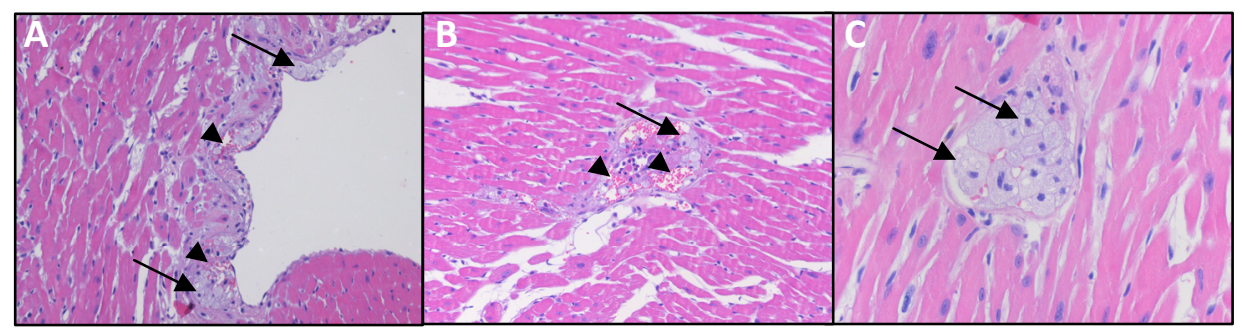

Figure 2. Representative H\&E of foam cell (arrows) and erythrocyte (arrowheads) accumulation in (A) the subendocardial layer and (B, C) thin-walled vessels at 20 weeks after 16 Gy cardiac irradiation of $A p o E^{--}$mice.

In contrast to high doses generally employed in radiotherapy, low radiation doses, as may be delivered by medical, environmental or occupational exposures, are suggested to be anti-inflammatory and atheroprotective. Doses below $1 \mathrm{~Gy}$ reduced leukocyte adhesion to ECs in vitro and in vivo due to elevated expression of the anti-inflammatory cytokine transforming growth factor $\beta$ (TGF $\beta$ ) $1^{101,102}$, decreased expression of adhesion molecules such as E-selectin ${ }^{103}$ and diminished chemokine CCL20 expression ${ }^{104}$. Interestingly, low-dose radiation exposure ( $\leq 1 \mathrm{~Gy}$ ) of murine macrophages before skewing towards a pro-inflammatory $M 1$ phenotype decreased inducible nitric oxide synthase (iNOS) ${ }^{105}$ and $\mathrm{TNF}^{106}$ production, as well as reduced the oxidative burst ${ }^{107}$. In a recent study using activated human monocyte cell line-derived macrophages, a significant decrease in IL-1 $\beta$ secretion after 0.5 and $0.7 \mathrm{~Gy}$ was observed. ${ }^{108}$ The effect of whole body lowdose $(\leq 0.5 \mathrm{~Gy}$ ) radiation on splenocytes has recently been investigated in C57BL/6J mice. Low doses decreased expression of $\mathrm{Th}_{1^{-}}$and $\mathrm{Th}_{2}$-related cytokines, whereas a higher dose of $2 \mathrm{~Gy}$ induced an increased immune response. ${ }^{109}$ In line with these findings, Mitchel et al. found that a total body 
exposure of less than $0.5 \mathrm{~Gy}$ decreased the number and size of atherosclerotic lesions in $\mathrm{ApoE}^{-1}$ mice. ${ }^{110}$ In addition, intracoronary low-dose irradiation prevented neointima formation after coronary injury in pig. ${ }^{111}$ Other preclinical models of inflammatory disorders confirming low-dose radiation-induced antiinflammatory properties are reviewed by Rödel et al. ${ }^{112}$ Furthermore, evidence from atomic-bomb survivors indicated that heart diseases significantly associated with low-dose radiation were related to capillary perfusion defects, inflammation and fibrosis (congestive heart failure and rheumatic heart disease), but not to coronary atherosclerosis, and analysis restricted to doses lower than 0.5 Gy showed no significant risk increments for heart diseases. ${ }^{113-}$ 115 The degree of risk for heart diseases at doses below 0.5 Gy therefore remains unclear. Further elucidation of the existence of a threshold dose below which there is no increased risk of CVD is extremely relevant for therapeutic measures and the development of better treatment guidelines.

\section{Potential mechanisms of radiation-induced atherosclerosis progression}

\section{DNA damage}

Another mechanism by which radiotherapy can increase the risk for CVD presenting years after the initial exposure is accelerating the progression of a stable towards an unstable atherosclerotic plaque. Ionizing radiation of an existing plaque can directly or indirectly (through the production of hydroxyl radicals resulting from the ionization of water or by exposing to free radicals) cause DNA double strand breaks of cells in situ, activating DNA damage checkpoints. ${ }^{116}$ Bennett et al. recently showed that cumulative DNA damage of intimal macrophages and vascular SMCs (vSMCs) in the plaque led to premature senescence (i.e. irreversible growth arrest) and cell death. ${ }^{117,} 118$ Subsequent secondary necrosis (i.e. loss of cell membrane integrity causing leakage of toxic intracellular material) of macrophages will promote inflammation and necrotic core expansion, rendering the plaque more unstable. ${ }^{119}$ vSMC death results in multiple features of plaque instability, like a marked thinning of the fibrous cap, loss of collagen, larger necrotic core and intimal hyperinflammation. ${ }^{120-123}$ Moreover, radiation can also directly trigger cell senescence after telomere damage. ${ }^{124}$ There is extensive evidence in human and mouse models that plaque macrophages and vSMCs express 
markers of (oxidative) DNA damage, senescence and apoptosis, which increased with disease progression. ${ }^{125,126}$ Shortened telomeres have also been reported in circulating leukocytes of patients with CAD. ${ }^{127}$ On the other hand, telomerase was activated in macrophages during experimental atherosclerotic formation ${ }^{128}$ and telomere shortening impaired proliferation of both lymphocytes and macrophages resulting in reduced atherosclerosis in $\mathrm{ApoE}^{\prime-}$ mice. $^{129}$

Although it has to be further elucidated which lesional cell types are the most sensitive for radiation-induced senescence or apoptosis, either oxidative stress or DNA damage could be major targets for controlling radiationassociated atherosclerosis progression. In this respect, Tribble et al. have shown that oxidative damage and inflammation in radiation-induced atherosclerosis could be inhibited by overexpression of the antioxidant superoxide dismutase. ${ }^{130}$ In addition, anti-oxidant diet has been shown to inhibit atherosclerosis and reduce lesional macrophage and oxidized (ox) LDL content in balloon-injured arteries of irradiated hypercholesterolemic rabbits. ${ }^{131}$

In conclusion, radiation-induced oxidative damage and cell death could lead to chronic inflammation and transform the phenotype of an existing stable plaque to an unstable phenotype.

\section{Macrophage polarization}

A macrophage-rich, in particular pro-inflammatory M1 macrophages, thrombotic phenotype and increased number of lesional apoptotic cells longterm after plaque irradiation has been shown in chapter 4 . The atherosclerotic plaque contains a wide range of local factors, such as cytokines (e.g. IFN- $\gamma$, IL4, IL13 and IL10), chemokines (e.g. chemokine (C-X-C motif) ligand (CXCL) $4^{132}$ and chemokine ( $\mathrm{C}-\mathrm{C}$ motif) ligand $(\mathrm{CCL}) 2^{133}$ ), growth factors (macrophage colony-stimulating factor (M-CSF) and granulocyte (G)M-SCF ${ }^{134}$ ) and lipid mediators ${ }^{135}$. These factors exert essential roles in monocyte differentiation into heterogeneous macrophage populations exhibiting a broader spectrum of phenotypes than the extremes identified in vitro. Macrophages maintain phenotypic plasticity, meaning that alteration of micro-environmental signals can shift their differentiated phenotype and subsequent function back and forth from pro- M1 to anti-inflammatory M2. ${ }^{136}$ Khallou-Laschet et al. reported 
that bone-marrow derived macrophages, polarized to an M1 or M2 phenotype, were able to reverse their phenotype when the culture conditions were switched. ${ }^{137}$ This was supported by in vivo studies showing that M2 macrophages predominated in initial lesions that were enriched in M-CSF and the $\mathrm{Th}_{2}$-cytokine IL-4, as well as in regressing plaques, but switched to a M1 phenotype producing pro-inflammatory cytokines when the plaque progressed in size and complexity and contained high levels of pro-atherogenic $\mathrm{Th}_{1}$ cytokine IFN- $y .{ }^{137-139}$ Similarly, M1 macrophages characterized by a high proinflammatory cytokine expression profile were associated with symptomatic carotid atherosclerotic disease in humans. ${ }^{140}$ Taken together, changes in plaque micro-environmental signals, also those induced by irradiation, can induce a phenotypic conversion of plaque macrophages, rendering the plaque more inflammatory. Most likely also a direct effect of irradiation on the inflammatory status of macrophages (as demonstrated in our in vitro studies in chapter 4) and newly recruited monocytes from the circulation play a significant role. There is also data that emphasize the need for investigating the effect of irradiation on VSMCs. Impaired phagocytosis leading to secondary necrosis of apoptotic vSMCs in atherosclerosis releases IL-1 $\alpha$. IL-1 $\alpha$ subsequently stimulates surrounding viable vSMCs to release IL-6 and monocyte chemotactic protein (MCP)-1, thereby attracting more macrophages. ${ }^{120,123}$

Interestingly, as stated above, we have shown that M1 macrophages outnumber M2 macrophages in irradiated murine atherosclerotic lesions containing increased numbers of apoptotic cells. As in vitro studies showed that M1 macrophages secrete MMPs and strongly phagocytose oxLDL rather than apoptotic cells, they are suggested to play a prominent role in promoting plaque inflammation. In contrast, M2 macrophages are less prone to form foam cells, but are highly effective in clearing apoptotic cells, thereby preventing secondary necrosis and triggering anti-inflammatory responses. ${ }^{141}$ Therefore, they are suggested to be protective in atherosclerosis. ${ }^{142,143}$ Indeed, shifting the balance towards M2 macrophages reduced circulating cholesterol levels ${ }^{144,145}$ and plaque size ${ }^{146-148}$ in hypercholesterolemic mice. Moreover, a recent study investigated the spatial distribution of polarized $\mathrm{M} 1$ and $\mathrm{M} 2$ macrophages in advanced human atherosclerosis. It was shown that proatherogenic M1 macrophages preferentially locate in rupture-prone shoulder 
regions of plaques, while $\mathrm{M} 2$ macrophages were more prominent in the vascular adventitia, implying that inflammation is the driving force for fibrous cap rupture and subsequent cardiovascular events. ${ }^{149}$ Indeed, in vitro coculture experiments indicated that macrophages could trigger apoptosis in SMCs by activating their Fas apoptotic pathway and by secreting pro-apoptotic TNF $\alpha$ and NO, which could lead to decreased synthesis of collagen and fibrous cap weakening. ${ }^{150}$ The radiation-induced imbalance in the ratio of lesional M1 and M2 macrophages therefore may cause impaired resolution of inflammation, ultimately leading to necrotic core expansion and enhanced plaque instability.

\section{Radiation-induced cardiac dysfunction}

The heart continues to be an organ at risk in cancer survivors that received thoracic radiotherapy, even despite improved radiotherapy techniques, such as tangential radiotherapy. ${ }^{151}$ Harris et al. observed an increased incidence of myocardial infarction after a median follow-up of 12 years in women irradiated for left-sided versus right-sided breast cancer between 1977 and $1994 .{ }^{152}$ The cardiac risk associated with modern treatment regimens cannot yet be assessed, as the increased risk of cardiac mortality will only become evident after a follow-up of minimum 10 years. Currently available retrospective and prospective studies have shown early regional myocardial perfusion defects (within 6 months to a few years after treatment) in asymptomatic breast cancer patients using functional imaging. ${ }^{153}$ Perfusion defects were substantially more observed in left-side treated patients compared to rightside treated patients. ${ }^{154,155}$ Marks et al. showed that the incidence of perfusion defects was related to the volume of the heart in the irradiation field. ${ }^{156}$ Furthermore, it was reported that the appearance of new perfusion defects continued up to 6 years after radiotherapy. ${ }^{157}$ These persistent radiationinduced perfusion defects are expected to contribute to the long-term increased risk for heart diseases, although the association in humans could not be proven yet. Longer follow-up of prospective studies will enable evaluation of the contribution of early radiation-induced micro- and macrovascular damage to the late development of symptomatic heart diseases and increased risk for cardiac mortality. Furthermore, retrospective analysis of clinical data and cardiac dosimetry of past regimens would enable to develop reliable dose- 
response relationships and to estimate the future risk of thoracic radiotherapy techniques used today, although comorbidity factors most likely influence final outcome. Modern radiotherapy techniques have considerably reduced the average dose exposure to the heart to <2 Gy, yet techniques such as IMRT (intensity modulated radiotherapy) can be associated with total body exposures of 2-3 Gy, again increasing the risk of cardiovascular damage. In addition, part of the heart, including the left anterior descending coronary artery (LADCA), still receives more than $20 \mathrm{~Gy}$ in about $50 \%$ of breast cancer patients treated with left-tangential radiotherapy. ${ }^{158,159}$ This dose was seen to result in left-ventricular perfusion defects in the first months and LADCA stenosis years after treatment, suggesting both micro- and macrovascular damage. ${ }^{160}$ Previous dosimetry studies showed that both recent breast cancer radiotherapy techniques and those used in the past tended to deliver the highest doses to the anterior part of the heart, including the LADCA, which is a common site of myocardial infarction. ${ }^{161-164}$

Next to the aforementioned substantial evidence of micro- and macrovascular injury in mice, radiation was also seen to result in pronounced structural myocardial (interstitial fibrosis) and epicardial damage (epicarditis). Nevertheless, murine cardiac function was maintained for up to 60 weeks after low (2 Gy) and intermediate (8 Gy) doses, whereas high-dose irradiation (16 Gy) led to sudden death in C57BL/6J mice (chapter 5). Moreover, we found that genes involved in survival pathways (heat shock proteins (Hsp), MMP2 and cyclin dependent kinase inhibitor $1 A(C D K N 1 A)$ ), regulating cellular development, growth and proliferation, were activated after low doses in parallel with inflammatory pathways, presumably in an attempt to stimulate recovery, while the expression profile switched to fibrotic pathways after highdose (chapter 6). The radiation-induced myocardial fibrosis and increased infiltration of inflammatory cells in the epicardium could not be circumvented by anti-inflammatory and -fibrotic thalidomide treatment, as recently investigated by Hoving et al. ${ }^{98}$ Although thalidomide has been proven protective in several diseases involving inflammation and fibrosis ${ }^{165-168}$, other strategies reducing radiation-induced heart damage have to be tested.

The increased mortality after high-dose irradiation was most likely due to extensive microvascular leakage resulting in extracellular deposition of amyloid fibrils, i.e. autologous protein in an abnormal insoluble $\beta$-pleated 
sheet fibrillary conformation. ${ }^{169,}{ }^{170}$ Recently it was proposed that radiationinduced oxidative stress in the heart of $\mathrm{C} 57 \mathrm{BL} / 6 \mathrm{~J}$ mice deactivated peroxisome proliferator-activated receptor (PPAR) $\alpha$, a key regulator of cardiac lipid metabolism and anti-inflammatory and -fibrotic responses, leading to a low level of myocardial lipid metabolism, mitochondrial dysfunction, increased ROS production, enhanced inflammation and cardiac amyloidosis. ${ }^{171-173}$ Cardiac amyloid deposition can cause progressive diastolic and subsequently systolic biventricular dysfunction and arrhythmia, associated with higher mortality. ${ }^{174}$ In general, cardiac amyloidosis has a poor prognosis, depending on the type of protein, degree of heart damage and response to therapy (recently reviewed by Banypersad et al. ${ }^{175}$ ). Amyloid deposits contain non-fibrillary constituents, such as $\mathrm{ApoE}$, and $\mathrm{ApoE}^{/-}$mice were protected from amyloidosis and subsequent cardiac dysfunction, but not from the development of coronary atherosclerosis after high-dose irradiation (chapter 6). ApoE is therefore essential in the development of cardiac amyloidosis.

It remains unclear which part of the heart is most radiosensitive and determines the long-term risk of CVD seen in epidemiological studies. In an ongoing project using $A p o E^{-/}$mice, we are investigating whether irradiation of the major branching points of the coronary arteries affects atherosclerosis development in mid-size vessels towards the apex, or whether radiation has a direct effect on smaller vessels even when major branching points are outside the irradiation field. For these ongoing experiments we made use of a cone beam irradiator to irradiate whole and partial volumes of the heart (basal or apical irradiation), as nowadays occurs in the clinical treatment of cancer patients.

\section{Possible targets and strategies for intervention of radiation-induced cardiovascular damage}

Cardiac microvascular endothelial damage was evident after $2 \mathrm{~Gy}$, most likely resulting in perfusion defects, diffuse ischemia and myocardial fibrosis, ultimately leading to congestive heart failure. In combination with elevated cholesterol levels, radiation doses of 8-16 Gy accelerated atherosclerosis development in coronary arteries and predisposed to a macrophage-rich, unstable plaque phenotype with thrombotic features in larger arteries. Specific interventions in thrombotic or inflammatory pathways are therefore suggested 
to be potential therapeutic approaches to prevent radiation-induced atherosclerosis. However, we recently demonstrated that chronic (NOdonating) aspirin treatment was effective in reducing age-related atherosclerosis in larger arteries of $\mathrm{ApOE}^{-\alpha}$ mice, but had no effect on radiation-induced atherosclerotic plaque development ${ }^{176}$, suggesting that other pathways are involved after irradiation. Thus, there is a high need for detailed knowledge about underlying molecular mechanisms of radiation to identify new leads for intervention and to design tailored therapies. Possible strategies to prevent radiation-associated cardiovascular injury are reducing DNA damage and immune therapy.

\section{DNA damage}

Pathways protecting lesional cells from oxidative DNA damage and its consequences are unclear. Sirtuin 1 deacetylase has been shown to promote DNA damage repair and to suppress apoptosis by targeting among others $p 53$, increasing resistance to DNA damage. ${ }^{177,178} \mathrm{ApoE}^{-/}$mice with sirtuin 1-deficient VSMCs exhibit elevated DNA damage markers and VSMC apoptosis, identifying sirtuin 1 as a potential protective protein in atherosclerosis. ${ }^{179}$ P53, the main sensor of DNA damage and transcriptional regulator of genes involved in cellular growth arrest and apoptosis, is activated following radiation-induced DNA damage, and could therefore serve as a potential target in preventing cell-specific apoptosis in atherosclerosis and subsequent accelerated plaque progression after radiotherapy. Although the role of $p 53$ in the induction of proliferation and apoptosis in atherosclerosis is controversial, it has been shown by Mercer et al. that endogenous p53 limited atherosclerosis development in $A p o E^{-/}$mice by protecting VSMCs from apoptosis, in part by inhibiting DNA damage response enzymes, while promoting macrophage apoptosis. ${ }^{180}$ Macrophage p53 deficiency decreased apoptosis and enhanced plaque macrophage content, thereby aggravating atherosclerosis. ${ }^{181,182}$ On the other hand, adenovirus expression of p53 induced apoptosis and plaque rupture in a collar-model of atherosclerosis in $A p o E^{-1-}$ mice. ${ }^{183}$ The adverse consequences of macrophage apoptosis may be explained by difference in plaque stage; in early atherosclerosis it can reduce plaque progression, while in advanced atherosclerosis it will contribute to necrotic core expansion and enhanced plaque instability. ${ }^{184}$ Furthermore, it was recently demonstrated that 
suppression of p53 reduced functional defects in endothelial progenitor cells after radiation exposure, which could prevent the onset of vascular disease. ${ }^{185}$ In addition, $\mathrm{ApoE}^{-/}$mice with reduced p53 functionality were exposed to lowdose irradiation at late stage atherosclerosis and showed increased lesion growth, while at early stage the atheroprotective effect of low dose (discussed on pages 183-184) was not affected. ${ }^{186}$ These studies indicate that the possible protective role of $\mathrm{p} 53$ in atherosclerosis depends on the cell type involved and plaque stage, influencing its use as a therapeutic target for regulating plaque stability.

\section{Immune therapy}

Another potential immunoregulatory mechanism protecting against radiationinduced accelerated inflammatory atherosclerosis is adiponectin treatment, favoring human and murine M2 macrophage polarization. ${ }^{187,}{ }^{188}$ Indeed, adiponectin has been shown effective, reducing age-related atherosclerosis in $A p o E^{\prime-}$ mice ${ }^{189}$ and increasing cholesterol efflux from human macrophages by the activation of liver $X$ receptor (LXR) $\alpha$ and PPARy. ${ }^{190}$ Similarly, as shown in this thesis, low-dose immunosuppressive FK506 treatment induced a M2 skewing and prevented atherosclerosis development in $\mathrm{ApoE}^{-/}$mice, while clinically a high-dose FK506 treatment is applied which increases the risk for $\mathrm{CVD}^{1}$. It is worth noting that pharmacological PPARy activation was seen to upregulate anti-oxidant enzymes and concomitantly induced antiinflammatory M2 pathways ${ }^{191-194}$, interfering in two major pathways in radiation injury. PPARy agonists (e.g. tesaglitazar) or ligands (e.g. pioglitazone) may therefore represent potential therapeutic agents and indeed have previously been shown to block both cholesterol-mediated and radiationinduced atherosclerosis. ${ }^{195,196}$ 


\section{Concluding remarks and future perspectives}

Taken together, our data showed that radiation-induced cardiovascular defects are primarily caused by diffuse damage to the microvasculature after moderate and therapeutic doses, leading to cardiac amyloidosis, and by accelerated inflammatory atherosclerosis in the presence of hypercholesterolemia. We propose that specifically selecting cancer patients with a high-risk profile, based on biomarkers representing (asymptomatic) cardiovascular damage, before and after radiotherapy may enable early prognostic stratification and preventive individualized measures for CVD during clinical follow-up. Developing guidelines for cancer treatment that take cardiovascular profile into account is pivotal to improve care and long-term survival of cancer patients receiving thoracic radiotherapy.

Based on results from this thesis, and recent literature, we propose that radiation-induced oxidative damage is a major causal factor in both accelerated atherosclerosis initiation and progression, by increasing endothelial damage and by inducing apoptosis and pro-inflammatory responses. Preventing or counteracting these adverse effects of radiotherapy and reducing conventional risk factors for CVD (e.g. hyperlipidemia and hypertension) will significantly improve care and long-term survival of cancer patients treated with thoracic radiotherapy. However, specific preventive measures for radiation-induced CVD in humans are not yet available. Potential therapeutic options of particular interest are stabilizing endothelial function, enhancing natural anti-oxidant pathways, reducing DNA damage and targeted (limiting general effects on the immune system) stimulation of antiinflammatory immune responses, before radiotherapy as well as during longterm follow-up. We showed a protective effect of low-dose immunesuppressive FK506 (nuclear factor of activated T-cells (NFAT) inhibitor) treatment in age-related atherosclerosis and suggested future therapeutic potential in selectively blocking calcineurin-NFAT interactions. Nevertheless, our group has shown that anti-inflammatory and -thrombotic intervention strategies were not efficient in reducing radiation-induced atherosclerosis in young mice. Currently, protective effects have only been reported for antioxidant strategies and PPARY activation in animal models of atherosclerosis. This indicates that radiation-induced oxidative damage should be a main target for therapy. 
Future research should address a range of critical open questions, all of which may have an impact on the choice of radiation treatment and course of follow-up. Some of these open questions include:

1. What are the underlying mechanisms of radiation-induced micro- and macrovascular damage and subsequent CVD?

2. Which biomarkers represent cardiovascular damage prior and after radiotherapy and are associated with an increased longterm risk for CVD?

3. Which are potential targets for preventive therapy?

4. Which medication should be given to cancer patients with a higher-risk profile and when?

Most importantly, further studies should be directed to map the molecular pathways involved in early radiation-induced micro- and macrovascular damage to provide important entries for diagnosis and/or prevention of radiotherapy-associated CVD. This will enable the design of potential tailored mechanism-based therapies and will improve treatment guidelines. 


\section{References}

1. Miller LW. Cardiovascular toxicities of immunosuppressive agents. American journal of transplantation : official journal of the American Society of Transplantation and the American Society of Transplant Surgeons. 2002;2:807-818

2. Matsumoto $T$, Saito E, Watanabe H, Fujioka T, Yamada T, Takahashi Y, Ueno T, Tochihara T, Kanmatsuse K. Influence of fk506 on experimental atherosclerosis in cholesterol-fed rabbits. Atherosclerosis. 1998;139:95-106

3. Donners MM, Bot I, De Windt LJ, van Berkel TJ, Daemen MJ, Biessen EA, Heeneman S. Low-dose fk506 blocks collar-induced atherosclerotic plaque development and stabilizes plaques in apoe-/- mice. American journal of transplantation : official journal of the American Society of Transplantation and the American Society of Transplant Surgeons. 2005;5:1204-1215

4. Macian F. Nfat proteins: Key regulators of t-cell development and function. Nature reviews. Immunology. 2005;5:472-484

5. Buxade M, Lunazzi G, Minguillon J, Iborra S, Berga-Bolanos R, Del Val M, Aramburu J, Lopez-Rodriguez C. Gene expression induced by toll-like receptors in macrophages requires the transcription factor nfat5. The Journal of experimental medicine. 2012;209:379-393

6. Halterman JA, Kwon HM, Leitinger N, Wamhoff BR. Nfat5 expression in bone marrowderived cells enhances atherosclerosis and drives macrophage migration. Frontiers in physiology. 2012;3:313

7. Zanoni I, Ostuni R, Capuano G, Collini M, Caccia M, Ronchi AE, Rocchetti M, Mingozzi F, Foti M, Chirico G, Costa B, Zaza A, Ricciardi-Castagnoli P, Granucci F. Cd14 regulates the dendritic cell life cycle after Ips exposure through nfat activation. Nature. 2009;460:264-268

8. Goodridge HS, Simmons RM, Underhill DM. Dectin-1 stimulation by candida albicans yeast or zymosan triggers nfat activation in macrophages and dendritic cells. Journal of immunology. 2007;178:3107-3115

9. Walczak-Drzewiecka A, Ratajewski M, Wagner W, Dastych J. Hif-1alpha is up-regulated in activated mast cells by a process that involves calcineurin and nfat. Journal of immunology. 2008;181:1665-1672

10. Ulleras E, Karlberg M, Moller Westerberg C, Alfredsson J, Gerondakis S, Strasser A, Nilsson G. Nfat but not nf-kappab is critical for transcriptional induction of the prosurvival gene a1 after ige receptor activation in mast cells. Blood. 2008;111:30813089

11. Klein $M$, Klein-Hessling S, Palmetshofer A, Serfling E, Tertilt C, Bopp T, Heib V, Becker $M$, Taube $C$, Schild $H$, Schmitt E, Stassen M. Specific and redundant roles for nfat transcription factors in the expression of mast cell-derived cytokines. Journal of immunology. 2006;177:6667-6674

12. Haylett RS, Koch N, Rink L. Mhc class ii molecules activate nfat and the erk group of mapk through distinct signaling pathways in b cells. European journal of immunology. 2009;39:1947-1955

13. de Gorter DJ, Vos JC, Pals ST, Spaargaren M. The b cell antigen receptor controls ap-1 and nfat activity through ras-mediated activation of ral. Journal of immunology. 2007;178:1405-1414

14. Winslow MM, Gallo EM, Neilson JR, Crabtree GR. The calcineurin phosphatase complex modulates immunogenic b cell responses. Immunity. 2006;24:141-152 
15. Berland $\mathrm{R}$, Wortis $\mathrm{HH}$. Normal b-1a cell development requires b cell-intrinsic nfatc1 activity. Proceedings of the National Academy of Sciences of the United States of America. 2003;100:13459-13464

16. Kiani A, Garcia-Cozar FJ, Habermann I, Laforsch S, Aebischer T, Ehninger G, Rao A. Regulation of interferon-gamma gene expression by nuclear factor of activated $t$ cells. Blood. 2001;98:1480-1488

17. Kiani A, Viola JP, Lichtman AH, Rao A. Down-regulation of il-4 gene transcription and control of th2 cell differentiation by a mechanism involving nfat1. Immunity. 1997;7:849-860

18. Xanthoudakis S, Viola JP, Shaw KT, Luo C, Wallace JD, Bozza PT, Luk DC, Curran T, Rao A. An enhanced immune response in mice lacking the transcription factor nfat1. Science. 1996;272:892-895

19. Hodge MR, Ranger AM, Charles de la Brousse F, Hoey T, Grusby MJ, Glimcher LH. Hyperproliferation and dysregulation of il-4 expression in nf-atp-deficient mice. Immunity. 1996;4:397-405

20. Ghosh S, Koralov SB, Stevanovic I, Sundrud MS, Sasaki Y, Rajewsky K, Rao A, Muller MR. Hyperactivation of nuclear factor of activated t cells 1 (nfat1) in t cells attenuates severity of murine autoimmune encephalomyelitis. Proceedings of the National Academy of Sciences of the United States of America. 2010;107:15169-15174

21. Weigmann B, Lehr HA, Yancopoulos G, Valenzuela D, Murphy A, Stevens S, Schmidt J, Galle PR, Rose-John S, Neurath MF. The transcription factor nfatc2 controls il-6dependent $\mathrm{t}$ cell activation in experimental colitis. The Journal of experimental medicine. 2008;205:2099-2110

22. Porter $\mathrm{CM}$, Clipstone NA. Sustained nfat signaling promotes a th1-like pattern of gene expression in primary murine cd4+ t cells. Journal of immunology. 2002;168:4936-4945

23. Ranger AM, Hodge MR, Gravallese EM, Oukka M, Davidson L, Alt FW, de la Brousse FC, Hoey T, Grusby M, Glimcher LH. Delayed lymphoid repopulation with defects in il-4driven responses produced by inactivation of nf-atc. Immunity. 1998;8:125-134

24. Yoshida H, Nishina $H$, Takimoto $H$, Marengere LE, Wakeham AC, Bouchard D, Kong YY, Ohteki T, Shahinian A, Bachmann M, Ohashi PS, Penninger JM, Crabtree GR, Mak TW. The transcription factor nf-atc1 regulates lymphocyte proliferation and th2 cytokine production. Immunity. 1998;8:115-124

25. Peng SL, Gerth AJ, Ranger AM, Glimcher LH. Nfatc1 and nfatc2 together control both $t$ and $b$ cell activation and differentiation. Immunity. 2001;14:13-20

26. Oukka M, Ho IC, de la Brousse FC, Hoey T, Grusby MJ, Glimcher LH. The transcription factor nfat4 is involved in the generation and survival of t cells. Immunity. 1998;9:295304

27. Rengarajan J, Tang B, Glimcher LH. Nfatc2 and nfatc3 regulate $t(h) 2$ differentiation and

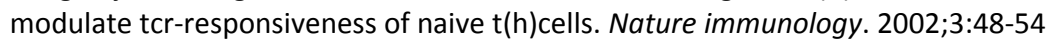

28. Ranger AM, Oukka M, Rengarajan J, Glimcher LH. Inhibitory function of two nfat family members in lymphoid homeostasis and th2 development. Immunity. 1998;9:627-635

29. Go WY, Liu X, Roti MA, Liu F, Ho SN. Nfat5/tonebp mutant mice define osmotic stress as a critical feature of the lymphoid microenvironment. Proceedings of the National Academy of Sciences of the United States of America. 2004;101:10673-10678

30. Avni O, Lee D, Macian F, Szabo SJ, Glimcher LH, Rao A. T(h) cell differentiation is accompanied by dynamic changes in histone acetylation of cytokine genes. Nature immunology. 2002;3:643-651

31. Monticelli S, Rao A. Nfat1 and nfat2 are positive regulators of il-4 gene transcription. European journal of immunology. 2002;32:2971-2978

32. Mallat $Z$, Taleb $S$, Ait-Oufella $H$, Tedgui $A$. The role of adaptive $t$ cell immunity in atherosclerosis. Journal of lipid research. 2009;50 Suppl:S364-369 
33. Davenport P, Tipping PG. The role of interleukin-4 and interleukin-12 in the progression of atherosclerosis in apolipoprotein e-deficient mice. The American journal of pathology. 2003;163:1117-1125

34. King VL, Szilvassy SJ, Daugherty A. Interleukin-4 deficiency decreases atherosclerotic lesion formation in a site-specific manner in female Idl receptor-/- mice. Arteriosclerosis, thrombosis, and vascular biology. 2002;22:456-461

35. George J, Shoenfeld Y, Gilburd B, Afek A, Shaish A, Harats D. Requisite role for interleukin-4 in the acceleration of fatty streaks induced by heat shock protein 65 or mycobacterium tuberculosis. Circulation research. 2000;86:1203-1210

36. King VL, Cassis LA, Daugherty A. Interleukin-4 does not influence development of hypercholesterolemia or angiotensin ii-induced atherosclerotic lesions in mice. The American journal of pathology. 2007;171:2040-2047

37. Cardilo-Reis L, Gruber S, Schreier SM, Drechsler M, Papac-Milicevic N, Weber C, Wagner O, Stangl H, Soehnlein O, Binder CJ. Interleukin-13 protects from atherosclerosis and modulates plaque composition by skewing the macrophage phenotype. EMBO molecular medicine. 2012;4:1072-1086

38. Binder CJ, Hartvigsen K, Chang MK, Miller M, Broide D, Palinski W, Curtiss LK, Corr M, Witztum JL. II-5 links adaptive and natural immunity specific for epitopes of oxidized Idl and protects from atherosclerosis. The Journal of clinical investigation. 2004;114:427437

39. Caligiuri G, Rudling M, Ollivier V, Jacob MP, Michel JB, Hansson GK, Nicoletti A. Interleukin-10 deficiency increases atherosclerosis, thrombosis, and low-density lipoproteins in apolipoprotein e knockout mice. Molecular medicine. 2003;9:10-17

40. Ghoreschi K, Thomas P, Breit S, Dugas M, Mailhammer R, van Eden W, van der Zee R, Biedermann T, Prinz J, Mack M, Mrowietz U, Christophers E, Schlondorff D, Plewig G, Sander CA, Rocken M. Interleukin-4 therapy of psoriasis induces th2 responses and improves human autoimmune disease. Nature medicine. 2003;9:40-46

41. Aramburu J, Yaffe MB, Lopez-Rodriguez C, Cantley LC, Hogan PG, Rao A. Affinity-driven peptide selection of an nfat inhibitor more selective than cyclosporin a. Science. 1999;285:2129-2133

42. Yu H, Sliedregt-Bol K, Overkleeft $H$, van der Marel GA, van Berkel TJ, Biessen EA. Therapeutic potential of a synthetic peptide inhibitor of nuclear factor of activated $t$ cells as antirestenotic agent. Arteriosclerosis, thrombosis, and vascular biology. 2006;26:1531-1537

43. Roehrl MH, Kang S, Aramburu J, Wagner G, Rao A, Hogan PG. Selective inhibition of calcineurin-nfat signaling by blocking protein-protein interaction with small organic molecules. Proceedings of the National Academy of Sciences of the United States of America. 2004;101:7554-7559

44. Noguchi H, Matsushita M, Okitsu T, Moriwaki A, Tomizawa K, Kang S, Li ST, Kobayashi N, Matsumoto S, Tanaka K, Tanaka N, Matsui H. A new cell-permeable peptide allows successful allogeneic islet transplantation in mice. Nature medicine. 2004;10:305-309

45. $\mathrm{Yu} \mathrm{H}$, van Berkel TJ, Biessen EA. Therapeutic potential of vivit, a selective peptide inhibitor of nuclear factor of activated $t$ cells, in cardiovascular disorders. Cardiovascular drug reviews. 2007; 25:175-187

46. Yu H, Bot I, Sliedregt $K, X u X$, Bot M, van Heiningen SH, van der Marel GA, Bennett MR, Overkleeft $\mathrm{H}$, van Berkel TJ, Biessen EA. Selective modulation of nuclear factor of activated t-cell function in restenosis by a potent bipartite peptide inhibitor. Circulation research. 2012;110:200-210

47. Schultz-Hector S, Trott KR. Radiation-induced cardiovascular diseases: Is the epidemiologic evidence compatible with the radiobiologic data? International journal of radiation oncology, biology, physics. 2007;67:10-18 
48. Adams MJ, Hardenbergh PH, Constine LS, Lipshultz SE. Radiation-associated cardiovascular disease. Critical reviews in oncology/hematology. 2003;45:55-75

49. Schultz-Hector S. Radiation-induced heart disease: Review of experimental data on dose response and pathogenesis. International journal of radiation biology. 1992;61:149-160

50. Lauk S. Endothelial alkaline phosphatase activity loss as an early stage in the development of radiation-induced heart disease in rats. Radiation research. 1987;110:118-128

51. Kanthou C GZ, Haagen J, et al. Inhibition of angiogenesis in the mouse heart by ionizing radiation. AACR 103rd Annual Meeting. Chicago: Cancer Research. 2012

52. Schultze-Mosgau S, Grabenbauer GG, Radespiel-Troger M, Wiltfang J, Ries J, Neukam FW, Rodel F. Vascularization in the transition area between free grafted soft tissues and pre-irradiated graft bed tissues following preoperative radiotherapy in the head and neck region. Head \& neck. 2002;24:42-51

53. Halle $M$, Bodin I, Tornvall $P$, Wickman M, Farnebo F, Arnander C. Timing of radiotherapy in head and neck free flap reconstruction--a study of postoperative complications. Journal of plastic, reconstructive \& aesthetic surgery : JPRAS. 2009;62:889-895

54. Stewart FA, Heeneman S, Te Poele J, Kruse J, Russell NS, Gijbels M, Daemen M. Ionizing radiation accelerates the development of atherosclerotic lesions in apoe-/- mice and predisposes to an inflammatory plaque phenotype prone to hemorrhage. The American journal of pathology. 2006;168:649-658

55. Hoving S, Heeneman S, Gijbels MJ, te Poele JA, Russell NS, Daemen MJ, Stewart FA. Single-dose and fractionated irradiation promote initiation and progression of atherosclerosis and induce an inflammatory plaque phenotype in apoe(-/-) mice. International journal of radiation oncology, biology, physics. 2008;71:848-857

56. Yu T, Parks BW, Yu S, Srivastava R, Gupta K, Wu X, Khaled S, Chang PY, Kabarowski JH, Kucik DF. Iron-ion radiation accelerates atherosclerosis in apolipoprotein e-deficient mice. Radiation research. 2011;175:766-773

57. Pakala R, Leborgne L, Cheneau E, Chan RC, Yazdi H, Fournadjiev J, Weber D, Hellinga D, Kolodgie F, Virmani R, Waksman R. Radiation-induced atherosclerotic plaque progression in a hypercholesterolemic rabbit: A prospective vulnerable plaque model? Cardiovascular radiation medicine. 2003;4:146-151

58. Virmani R, Farb A, Carter AJ, Jones RM. Comparative pathology: Radiation-induced coronary artery disease in man and animals. Seminars in interventional cardiology : SIIC. 1998;3:163-172

59. Darby SC, Ewertz M, McGale P, Bennet AM, Blom-Goldman U, Bronnum D, Correa C, Cutter D, Gagliardi G, Gigante B, Jensen MB, Nisbet A, Peto R, Rahimi K, Taylor C, Hall $P$. Risk of ischemic heart disease in women after radiotherapy for breast cancer. The New England journal of medicine. 2013;368:987-998

60. Hancock SL, Donaldson SS, Hoppe RT. Cardiac disease following treatment of hodgkin's disease in children and adolescents. Journal of clinical oncology : official journal of the American Society of Clinical Oncology. 1993;11:1208-1215

61. Hancock SL, Tucker MA, Hoppe RT. Factors affecting late mortality from heart disease after treatment of hodgkin's disease. JAMA : the journal of the American Medical Association. 1993;270:1949-1955

62. Dorresteijn LD, Kappelle AC, Scholz NM, Munneke M, Scholma JT, Balm AJ, Bartelink H, Boogerd W. Increased carotid wall thickening after radiotherapy on the neck. European journal of cancer. 2005;41:1026-1030 
63. Plummer C, Henderson RD, O'Sullivan JD, Read SJ. Ischemic stroke and transient ischemic attack after head and neck radiotherapy: A review. Stroke; a journal of cerebral circulation. 2011;42:2410-2418

64. Lee CC, Su YC, Ho HC, Hung SK, Lee MS, Chiou WY, Chou P, Huang YS. Increased risk of ischemic stroke in young nasopharyngeal carcinoma patients. International journal of radiation oncology, biology, physics. 2011;81:e833-838

65. Chu CN, Chen SW, Bai LY, Mou CH, Hsu CY, Sung FC. Increase in stroke risk in patients with head and neck cancer: A retrospective cohort study. British journal of cancer. 2011;105:1419-1423

66. De Bruin ML, Dorresteijn $L D$, van't Veer $M B$, Krol $A D$, van der Pal $H J$, Kappelle $A C$, Boogerd W, Aleman BM, van Leeuwen FE. Increased risk of stroke and transient ischemic attack in 5-year survivors of hodgkin lymphoma. Journal of the National Cancer Institute. 2009;101:928-937

67. Steele SR, Martin MJ, Mullenix PS, Crawford JV, Cuadrado DS, Andersen CA. Focused high-risk population screening for carotid arterial stenosis after radiation therapy for head and neck cancer. American journal of surgery. 2004;187:594-598

68. Greve J, Bas M, Schuler P, Turowski B, Scheckenbach K, Budach W, Bolke E, Bergmann C, Lang S, Arweiler-Harbeck D, Lehnerdt G, Mattheis S, Bier H, Hoffmann TK. Acute arterial hemorrhage following radiotherapy of oropharyngeal squamous cell carcinoma. Strahlentherapie und Onkologie : Organ der Deutschen Rontgengesellschaft ... [et al]. 2010;186:269-273

69. Andersen R, Wethal T, Gunther A, Fossa A, Edvardsen T, Fossa SD, Kjekshus J. Relation of coronary artery calcium score to premature coronary artery disease in survivors $>15$ years of hodgkin's lymphoma. The American journal of cardiology. 2010;105:149-152

70. Meeske KA, Siegel SE, Gilsanz V, Bernstein L, Nelson MB, Sposto R, Weaver FA, Lavey RS, Mack MP, Nelson MD, Jr. Premature carotid artery disease in pediatric cancer survivors treated with neck irradiation. Pediatric blood \& cancer. 2009;53:615-621

71. Hull MC, Morris CG, Pepine CJ, Mendenhall NP. Valvular dysfunction and carotid, subclavian, and coronary artery disease in survivors of hodgkin lymphoma treated with radiation therapy. JAMA : the journal of the American Medical Association. 2003;290:2831-2837

72. Beckman JA, Thakore A, Kalinowski BH, Harris JR, Creager MA. Radiation therapy impairs endothelium-dependent vasodilation in humans. Journal of the American College of Cardiology. 2001;37:761-765

73. Sugihara T, Hattori Y, Yamamoto Y, Qi F, Ichikawa R, Sato A, Liu MY, Abe K, Kanno M. Preferential impairment of nitric oxide-mediated endothelium-dependent relaxation in human cervical arteries after irradiation. Circulation. 1999;100:635-641

74. Bilora F, Pietrogrande F, Petrobelli F, Polato G, Pomerri F, Muzzio PC. Is radiation a risk factor for atherosclerosis? An echo-color doppler study on hodgkin and non-hodgkin patients. Tumori. 2006;92:295-298

75. Russell NS, Hoving S, Heeneman S, Hage JJ, Woerdeman LA, de Bree R, Lohuis PJ, Smeele L, Cleutjens J, Valenkamp A, Dorresteijn LD, Dalesio O, Daemen MJ, Stewart FA. Novel insights into pathological changes in muscular arteries of radiotherapy patients. Radiotherapy and oncology : journal of the European Society for Therapeutic Radiology and Oncology. 2009;92:477-483

76. Shariat M, Alias NA, Biswal BM. Radiation effects on the intima-media thickness of the common carotid artery in post-radiotherapy patients with head and neck malignancy. Postgraduate medical journal. 2008;84:609-612

77. Cheng SW, Ting AC, Wu LL. Ultrasonic analysis of plaque characteristics and intimalmedial thickness in radiation-induced atherosclerotic carotid arteries. European 
journal of vascular and endovascular surgery : the official journal of the European Society for Vascular Surgery. 2002;24:499-504

78. So NM, Lam WW, Chook P, Woo KS, Liu KH, Leung SF, Wong KS, Metreweli C. Carotid intima-media thickness in patients with head and neck irradiation for the treatment of nasopharyngeal carcinoma. Clinical radiology. 2002;57:600-603

79. Mulrooney DA, Blaes AH, Duprez D. Vascular injury in cancer survivors. Journal of cardiovascular translational research. 2012;5:287-295

80. Stewart FA, Hoving S, Russell NS. Vascular damage as an underlying mechanism of cardiac and cerebral toxicity in irradiated cancer patients. Radiation research. 2010;174:865-869

81. Robbins ME, Zhao W. Chronic oxidative stress and radiation-induced late normal tissue injury: A review. International journal of radiation biology. 2004;80:251-259

82. Fajardo LF. The pathology of ionizing radiation as defined by morphologic patterns. Acta oncologica. 2005;44:13-22

83. Paris F, Fuks Z, Kang A, Capodieci P, Juan G, Ehleiter D, Haimovitz-Friedman A, CordonCardo C, Kolesnick R. Endothelial apoptosis as the primary lesion initiating intestinal radiation damage in mice. Science. 2001;293:293-297

84. Halle M, Gabrielsen A, Paulsson-Berne G, Gahm C, Agardh HE, Farnebo F, Tornvall P. Sustained inflammation due to nuclear factor-kappa $b$ activation in irradiated human arteries. Journal of the American College of Cardiology. 2010;55:1227-1236

85. Little MP, Tawn EJ, Tzoulaki I, Wakeford R, Hildebrandt G, Paris F, Tapio S, Elliott P. A systematic review of epidemiological associations between low and moderate doses of ionizing radiation and late cardiovascular effects, and their possible mechanisms. Radiation research. 2008;169:99-109

86. Heckmann M, Douwes K, Peter R, Degitz K. Vascular activation of adhesion molecule mrna and cell surface expression by ionizing radiation. Experimental cell research. 1998;238:148-154

87. Hoving S, Heeneman S, Gijbels MJ, Te Poele JA, Visser N, Cleutjens J, Russell NS, Daemen MJ, Stewart FA. Irradiation induces different inflammatory and thrombotic responses in carotid arteries of wildtype $c 57 \mathrm{bl} / 6 \mathrm{j}$ and atherosclerosis-prone apoe(-/-) mice. Radiotherapy and oncology : journal of the European Society for Therapeutic Radiology and Oncology. 2012;105:365-370

88. Khaled S, Gupta KB, Kucik DF. Ionizing radiation increases adhesiveness of human aortic endothelial cells via a chemokine-dependent mechanism. Radiation research. 2012;177:594-601

89. Baluna RG, Eng TY, Thomas CR. Adhesion molecules in radiotherapy. Radiation research. 2006;166:819-831

90. Wondergem J, Wedekind LE, Bart Cl, Chin A, van der Laarse A, Beekhuizen H. Irradiation of mechanically-injured human arterial endothelial cells leads to increased gene expression and secretion of inflammatory and growth promoting cytokines. Atherosclerosis. 2004;175:59-67

91. Van der Meeren A, Vandamme M, Squiban C, Gaugler MH, Mouthon MA. Inflammatory reaction and changes in expression of coagulation proteins on lung endothelial cells after total-body irradiation in mice. Radiation research. 2003;160:637646

92. Wang J, Zheng $\mathrm{H}$, Ou X, Fink LM, Hauer-Jensen M. Deficiency of microvascular thrombomodulin and up-regulation of protease-activated receptor-1 in irradiated rat intestine: Possible link between endothelial dysfunction and chronic radiation fibrosis. The American journal of pathology. 2002;160:2063-2072

93. Hallahan DE, Virudachalam S. Accumulation of $p$-selectin in the lumen of irradiated blood vessels. Radiation research. 1999;152:6-13 
94. Quarmby S, Kumar P, Kumar S. Radiation-induced normal tissue injury: Role of adhesion molecules in leukocyte-endothelial cell interactions. International journal of cancer. Journal international du cancer. 1999;82:385-395

95. Richter KK, Fink LM, Hughes BM, Sung CC, Hauer-Jensen M. Is the loss of endothelial thrombomodulin involved in the mechanism of chronicity in late radiation enteropathy? Radiotherapy and oncology : journal of the European Society for Therapeutic Radiology and Oncology. 1997;44:65-71

96. Hallahan D, Kuchibhotla J, Wyble C. Cell adhesion molecules mediate radiationinduced leukocyte adhesion to the vascular endothelium. Cancer research. 1996;56:5150-5155

97. Jelonek K, Walaszczyk A, Gabrys D, Pietrowska M, Kanthou C, Widlak P. Cardiac endothelial cells isolated from mouse heart - a novel model for radiobiology. Acta biochimica Polonica. 2011;58:397-404

98. Hoving S, Seemann I, Visser NL, Te Poele JA, Stewart FA. Thalidomide is not able to inhibit radiation-induced heart disease. International journal of radiation biology. 2013

99. Scharpfenecker $M$, Floot B, Russell NS, Ten Dijke P, Stewart FA. Endoglin haploinsufficiency reduces radiation-induced fibrosis and telangiectasia formation in mouse kidneys. Radiotherapy and oncology : journal of the European Society for Therapeutic Radiology and Oncology. 2009;92:484-491

100. Turesson I, Notter G. The influence of fraction size in radiotherapy on the late normal tissue reaction--i: Comparison of the effects of daily and once-a-week fractionation on human skin. International journal of radiation oncology, biology, physics. 1984;10:593598

101. Arenas M, Gil F, Gironella M, Hernandez V, Jorcano S, Biete A, Pique JM, Panes J. Antiinflammatory effects of low-dose radiotherapy in an experimental model of systemic inflammation in mice. International journal of radiation oncology, biology, physics. 2006;66:560-567

102. Roedel F, Kley N, Beuscher HU, Hildebrandt G, Keilholz L, Kern P, Voll R, Herrmann M, Sauer R. Anti-inflammatory effect of low-dose $x$-irradiation and the involvement of a tgf-beta1-induced down-regulation of leukocyte/endothelial cell adhesion. International journal of radiation biology. 2002;78:711-719

103. Hildebrandt G, Maggiorella L, Rodel F, Rodel V, Willis D, Trott KR. Mononuclear cell adhesion and cell adhesion molecule liberation after $\mathrm{x}$-irradiation of activated endothelial cells in vitro. International journal of radiation biology. 2002;78:315-325

104. Rodel F, Hofmann D, Auer J, Keilholz L, Rollinghoff M, Sauer R, Beuscher HU. The antiinflammatory effect of low-dose radiation therapy involves a diminished ccl20 chemokine expression and granulocyte/endothelial cell adhesion. Strahlentherapie und Onkologie : Organ der Deutschen Rontgengesellschaft ... [et al]. 2008;184:41-47

105. Hildebrandt G, Seed MP, Freemantle CN, Alam CA, Colville-Nash PR, Trott KR. Mechanisms of the anti-inflammatory activity of low-dose radiation therapy. International journal of radiation biology. 1998;74:367-378

106. Tsukimoto $M$, Homma $T$, Mutou $Y$, Kojima S. 0.5 gy gamma radiation suppresses production of tnf-alpha through up-regulation of mkp-1 in mouse macrophage raw264.7 cells. Radiation research. 2009;171:219-224

107. Schaue D, Marples B, Trott KR. The effects of low-dose x-irradiation on the oxidative burst in stimulated macrophages. International journal of radiation biology. 2002;78:567-576

108. Lodermann B, Wunderlich R, Frey S, Schorn C, Stangl S, Rodel F, Keilholz L, Fietkau R, Gaipl US, Frey B. Low dose ionising radiation leads to a nf-kappab dependent decreased secretion of active il-1beta by activated macrophages with a discontinuous dose-dependency. International journal of radiation biology. 2012;88:727-734 
109. Bogdandi EN, Balogh A, Felgyinszki N, Szatmari T, Persa E, Hildebrandt G, Safrany G, Lumniczky K. Effects of low-dose radiation on the immune system of mice after totalbody irradiation. Radiation research. 2010;174:480-489

110. Mitchel RE, Hasu M, Bugden M, Wyatt $H$, Little MP, Gola A, Hildebrandt G, Priest ND, Whitman SC. Low-dose radiation exposure and atherosclerosis in apoe(-)/(-) mice. Radiation research. 2011;175:665-676

111. Waksman R, Robinson KA, Crocker IR, Gravanis MB, Cipolla GD, King SB, 3rd. Endovascular low-dose irradiation inhibits neointima formation after coronary artery balloon injury in swine. A possible role for radiation therapy in restenosis prevention. Circulation. 1995;91:1533-1539

112. Rodel F, Frey B, Manda K, Hildebrandt G, Hehlgans S, Keilholz L, Seegenschmiedt MH, Gaipl US, Rodel C. Immunomodulatory properties and molecular effects in inflammatory diseases of low-dose x-irradiation. Frontiers in oncology. 2012;2:120

113. Shimizu $Y$, Kodama K, Nishi N, Kasagi F, Suyama A, Soda M, Grant EJ, Sugiyama H, Sakata R, Moriwaki H, Hayashi M, Konda M, Shore RE. Radiation exposure and circulatory disease risk: Hiroshima and nagasaki atomic bomb survivor data, 19502003. Bmj. 2010;340:b5349

114. Preston DL, Shimizu Y, Pierce DA, Suyama A, Mabuchi K. Studies of mortality of atomic bomb survivors. Report 13: Solid cancer and noncancer disease mortality: 1950-1997. Radiation research. 2003;160:381-407

115. Shimizu Y, Pierce DA, Preston DL, Mabuchi K. Studies of the mortality of atomic bomb survivors. Report 12, part ii. Noncancer mortality: 1950-1990. Radiation research. 1999;152:374-389

116. Fei P, El-Deiry WS. P53 and radiation responses. Oncogene. 2003;22:5774-5783

117. Gray K, Bennett M. Role of DNA damage in atherosclerosis--bystander or participant? Biochemical pharmacology. 2011;82:693-700

118. Mercer J, Mahmoudi M, Bennett M. DNA damage, p53, apoptosis and vascular disease. Mutation research. 2007;621:75-86

119. Bennett $\mathrm{M}, \mathrm{Yu} \mathrm{H}$, Clarke M. Signalling from dead cells drives inflammation and vessel remodelling. Vascular pharmacology. 2012;56:187-192

120. Clarke MC, Talib S, Figg NL, Bennett MR. Vascular smooth muscle cell apoptosis induces interleukin-1-directed inflammation: Effects of hyperlipidemia-mediated inhibition of phagocytosis. Circulation research. 2010;106:363-372

121. Clarke MC, Littlewood TD, Figg N, Maguire JJ, Davenport AP, Goddard M, Bennett MR. Chronic apoptosis of vascular smooth muscle cells accelerates atherosclerosis and promotes calcification and medial degeneration. Circulation research. 2008;102:15291538

122. Clarke $M$, Bennett $M$. The emerging role of vascular smooth muscle cell apoptosis in atherosclerosis and plaque stability. American journal of nephrology. 2006;26:531-535

123. Clarke MC, Figg N, Maguire JJ, Davenport AP, Goddard M, Littlewood TD, Bennett MR. Apoptosis of vascular smooth muscle cells induces features of plaque vulnerability in atherosclerosis. Nature medicine. 2006;12:1075-1080

124. Hewitt G, Jurk D, Marques FD, Correia-Melo C, Hardy T, Gackowska A, Anderson R, Taschuk M, Mann J, Passos JF. Telomeres are favoured targets of a persistent DNA damage response in ageing and stress-induced senescence. Nature communications. 2012;3:708

125. Mahmoudi M, Gorenne I, Mercer J, Figg N, Littlewood T, Bennett M. Statins use a novel nijmegen breakage syndrome-1-dependent pathway to accelerate DNA repair in vascular smooth muscle cells. Circulation research. 2008;103:717-725

126. Matthews C, Gorenne I, Scott S, Figg N, Kirkpatrick P, Ritchie A, Goddard M, Bennett M. Vascular smooth muscle cells undergo telomere-based senescence in human 
atherosclerosis: Effects of telomerase and oxidative stress. Circulation research. 2006;99:156-164

127. Brouilette SW, Moore JS, McMahon AD, Thompson JR, Ford I, Shepherd J, Packard CJ, Samani NJ, West of Scotland Coronary Prevention Study G. Telomere length, risk of coronary heart disease, and statin treatment in the west of scotland primary prevention study: A nested case-control study. Lancet. 2007;369:107-114

128. Gizard F, Heywood EB, Findeisen HM, Zhao Y, Jones KL, Cudejko C, Post GR, Staels B, Bruemmer $\mathrm{D}$. Telomerase activation in atherosclerosis and induction of telomerase reverse transcriptase expression by inflammatory stimuli in macrophages. Arteriosclerosis, thrombosis, and vascular biology. 2011;31:245-252

129. Poch E, Carbonell P, Franco S, Diez-Juan A, Blasco MA, Andres V. Short telomeres protect from diet-induced atherosclerosis in apolipoprotein e-null mice. FASEB journal : official publication of the Federation of American Societies for Experimental Biology. 2004;18:418-420

130. Tribble DL, Barcellos-Hoff MH, Chu BM, Gong EL. Ionizing radiation accelerates aortic lesion formation in fat-fed mice via sod-inhibitable processes. Arteriosclerosis, thrombosis, and vascular biology. 1999;19:1387-1392

131. Leborgne L, Pakala R, Dilcher C, Hellinga D, Seabron R, Tio FO, Waksman R. Effect of antioxidants on atherosclerotic plaque formation in balloon-denuded and irradiated hypercholesterolemic rabbits. Journal of cardiovascular pharmacology. 2005;46:540547

132. Gleissner CA, Shaked I, Erbel C, Bockler D, Katus HA, Ley K. Cxcl4 downregulates the atheroprotective hemoglobin receptor cd163 in human macrophages. Circulation research. 2010;106:203-211

133. Roca H, Varsos ZS, Sud S, Craig MJ, Ying C, Pienta KJ. Ccl2 and interleukin-6 promote survival of human cd11b+ peripheral blood mononuclear cells and induce m2-type macrophage polarization. The Journal of biological chemistry. 2009;284:34342-34354

134. Fleetwood AJ, Dinh H, Cook AD, Hertzog PJ, Hamilton JA. Gm-csf- and m-csf-dependent macrophage phenotypes display differential dependence on type i interferon signaling. Journal of leukocyte biology. 2009;86:411-421

135. Kadl A, Meher AK, Sharma PR, Lee MY, Doran AC, Johnstone SR, Elliott MR, Gruber F, Han J, Chen W, Kensler T, Ravichandran KS, Isakson BE, Wamhoff BR, Leitinger N. Identification of a novel macrophage phenotype that develops in response to atherogenic phospholipids via nrf2. Circulation research. 2010;107:737-746

136. Porcheray F, Viaud S, Rimaniol AC, Leone C, Samah B, Dereuddre-Bosquet N, Dormont D, Gras G. Macrophage activation switching: An asset for the resolution of inflammation. Clinical and experimental immunology. 2005;142:481-489

137. Khallou-Laschet J, Varthaman A, Fornasa G, Compain C, Gaston AT, Clement M, Dussiot M, Levillain O, Graff-Dubois S, Nicoletti A, Caligiuri G. Macrophage plasticity in experimental atherosclerosis. PloS one. 2010;5:e8852

138. Feig JE, Rong JX, Shamir R, Sanson M, Vengrenyuk $Y$, Liu J, Rayner K, Moore K, Garabedian M, Fisher EA. Hdl promotes rapid atherosclerosis regression in mice and alters inflammatory properties of plaque monocyte-derived cells. Proceedings of the National Academy of Sciences of the United States of America. 2011;108:7166-7171

139. Feig JE, Parathath S, Rong JX, Mick SL, Vengrenyuk Y, Grauer L, Young SG, Fisher EA. Reversal of hyperlipidemia with a genetic switch favorably affects the content and inflammatory state of macrophages in atherosclerotic plaques. Circulation. 2011;123:989-998

140. Shalhoub J CA, Allin D, et al. . Cytokine profiling in culture reveals a predominance of $\mathrm{m} 1$ macrophage polarization in symptomatic carotid plaques. Presented on the BSCR Spring Meeting. 2010;96(17):e23-e23 
141. Van Vre EA, Ait-Oufella H, Tedgui A, Mallat Z. Apoptotic cell death and efferocytosis in atherosclerosis. Arteriosclerosis, thrombosis, and vascular biology. 2012;32:887-893

142. Chinetti-Gbaguidi G, Baron M, Bouhlel MA, Vanhoutte J, Copin C, Sebti Y, Derudas B, Mayi T, Bories G, Tailleux A, Haulon S, Zawadzki C, Jude B, Staels B. Human atherosclerotic plaque alternative macrophages display low cholesterol handling but high phagocytosis because of distinct activities of the ppargamma and Ixralpha pathways. Circulation research. 2011;108:985-995

143. Gordon S, Martinez FO. Alternative activation of macrophages: Mechanism and functions. Immunity. 2010;32:593-604

144. Stanley RG, Jackson CL, Griffiths K, Doenhoff MJ. Effects of schistosoma mansoni worms and eggs on circulating cholesterol and liver lipids in mice. Atherosclerosis. 2009;207:131-138

145. Doenhoff MJ, Stanley RG, Griffiths K, Jackson CL. An anti-atherogenic effect of schistosoma mansoni infections in mice associated with a parasite-induced lowering of blood total cholesterol. Parasitology. 2002;125:415-421

146. El Hadri K, Mahmood DF, Couchie D, Jguirim-Souissi I, Genze F, Diderot V, Syrovets T, Lunov $\mathrm{O}$, Simmet $\mathrm{T}$, Rouis $\mathrm{M}$. Thioredoxin-1 promotes anti-inflammatory macrophages of the $\mathrm{m} 2$ phenotype and antagonizes atherosclerosis. Arteriosclerosis, thrombosis, and vascular biology. 2012;32:1445-1452

147. Salagianni M, Galani IE, Lundberg AM, Davos CH, Varela A, Gavriil A, Lyytikainen LP, Lehtimaki T, Sigala F, Folkersen L, Gorgoulis V, Lenglet S, Montecucco F, Mach F, Hedin U, Hansson GK, Monaco C, Andreakos E. Toll-like receptor 7 protects from atherosclerosis by constraining "inflammatory" macrophage activation. Circulation. 2012;126:952-962

148. Lutgens E, Lievens D, Beckers L, Wijnands E, Soehnlein O, Zernecke A, Seijkens T, Engel D, Cleutjens J, Keller AM, Naik SH, Boon L, Oufella HA, Mallat Z, Ahonen CL, Noelle RJ, de Winther MP, Daemen MJ, Biessen EA, Weber C. Deficient cd40-traf6 signaling in leukocytes prevents atherosclerosis by skewing the immune response toward an antiinflammatory profile. The Journal of experimental medicine. 2010;207:391-404

149. Stoger JL, Gijbels MJ, van der Velden S, Manca M, van der Loos CM, Biessen EA, Daemen MJ, Lutgens E, de Winther MP. Distribution of macrophage polarization markers in human atherosclerosis. Atherosclerosis. 2012;225:461-468

150. Boyle JJ, Weissberg PL, Bennett MR. Tumor necrosis factor-alpha promotes macrophage-induced vascular smooth muscle cell apoptosis by direct and autocrine mechanisms. Arteriosclerosis, thrombosis, and vascular biology. 2003;23:1553-1558

151. Taylor CW, McGale P, Darby SC. Cardiac risks of breast-cancer radiotherapy: A contemporary view. Clinical oncology. 2006;18:236-246

152. Harris EE, Correa C, Hwang WT, Liao J, Litt HI, Ferrari VA, Solin L. Late cardiac mortality and morbidity in early-stage breast cancer patients after breast-conservation treatment. Journal of clinical oncology : official journal of the American Society of Clinical Oncology. 2006;24:4100-4106

153. Hardenbergh PH, Munley MT, Bentel GC, Kedem R, Borges-Neto S, Hollis D, Prosnitz LR, Marks LB. Cardiac perfusion changes in patients treated for breast cancer with radiation therapy and doxorubicin: Preliminary results. International journal of radiation oncology, biology, physics. 2001;49:1023-1028

154. Tzonevska A, Tzvetkov K, Parvanova V, Dimitrova M. 99mtc-mibi myocardial perfusion scintigraphy for assessment of myocardial damage after radiotherapy in patients with breast cancer. Journal of B.U.ON. : official journal of the Balkan Union of Oncology. 2006;11:505-509

155. Seddon B, Cook A, Gothard L, Salmon E, Latus K, Underwood SR, Yarnold J. Detection of defects in myocardial perfusion imaging in patients with early breast cancer treated 
with radiotherapy. Radiotherapy and oncology : journal of the European Society for Therapeutic Radiology and Oncology. 2002;64:53-63

156. Marks LB, Yu X, Prosnitz RG, Zhou SM, Hardenbergh PH, Blazing $M$, Hollis D, Lind $P$, Tisch $\mathrm{A}$, Wong TZ, Borges-Neto $\mathrm{S}$. The incidence and functional consequences of rtassociated cardiac perfusion defects. International journal of radiation oncology, biology, physics. 2005;63:214-223

157. Prosnitz RG, Hubbs JL, Evans ES, Zhou SM, Yu X, Blazing MA, Hollis DR, Tisch A, Wong TZ, Borges-Neto S, Hardenbergh PH, Marks LB. Prospective assessment of radiotherapy-associated cardiac toxicity in breast cancer patients: Analysis of data 3 to 6 years after treatment. Cancer. 2007;110:1840-1850

158. Borst GR, Sonke JJ, den Hollander S, Betgen A, Remeijer P, van Giersbergen A, Russell NS, Elkhuizen PH, Bartelink $H$, van Vliet-Vroegindeweij C. Clinical results of imageguided deep inspiration breath hold breast irradiation. International journal of radiation oncology, biology, physics. 2010;78:1345-1351

159. Taylor CW, Povall JM, McGale P, Nisbet A, Dodwell D, Smith JT, Darby SC. Cardiac dose from tangential breast cancer radiotherapy in the year 2006. International journal of radiation oncology, biology, physics. 2008;72:501-507

160. Correa CR, Litt HI, Hwang WT, Ferrari VA, Solin L, Harris EE. Coronary artery findings after left-sided compared with right-sided radiation treatment for early-stage breast cancer. Journal of clinical oncology : official journal of the American Society of Clinical Oncology. 2007;25:3031-3037

161. Taylor CW, Bronnum D, Darby SC, Gagliardi G, Hall P, Jensen MB, McGale P, Nisbet A, Ewertz M. Cardiac dose estimates from danish and swedish breast cancer radiotherapy during 1977-2001. Radiotherapy and oncology : journal of the European Society for Therapeutic Radiology and Oncology. 2011;100:176-183

162. Taylor CW, McGale P, Povall JM, Thomas E, Kumar S, Dodwell D, Darby SC. Estimating cardiac exposure from breast cancer radiotherapy in clinical practice. International journal of radiation oncology, biology, physics. 2009;73:1061-1068

163. Taylor CW, Nisbet A, McGale P, Goldman U, Darby SC, Hall P, Gagliardi G. Cardiac doses from swedish breast cancer radiotherapy since the 1950s. Radiotherapy and oncology : journal of the European Society for Therapeutic Radiology and Oncology. 2009;90:127-135

164. Taylor CW, Nisbet A, McGale P, Darby SC. Cardiac exposures in breast cancer radiotherapy: 1950s-1990s. International journal of radiation oncology, biology, physics. 2007;69:1484-1495

165. Choe JY, Jung HJ, Park KY, Kum YS, Song GG, Hyun DS, Park SH, Kim SK. Anti-fibrotic effect of thalidomide through inhibiting tgf-beta-induced erk1/2 pathways in bleomycin-induced lung fibrosis in mice. Inflammation research : official journal of the European Histamine Research Society ... [et al.]. 2010;59:177-188

166. Kim DH, Kim YJ, Chang SA, Lee HW, Kim HN, Kim HK, Chang HJ, Sohn DW, Park YB. The protective effect of thalidomide on left ventricular function in a rat model of diabetic cardiomyopathy. European journal of heart failure. 2010;12:1051-1060

167. Tabata C, Tabata R, Kadokawa Y, Hisamori S, Takahashi M, Mishima M, Nakano T, Kubo $\mathrm{H}$. Thalidomide prevents bleomycin-induced pulmonary fibrosis in mice. Journal of immunology. 2007;179:708-714

168. Franks ME, Macpherson GR, Figg WD. Thalidomide. Lancet. 2004;363:1802-1811

169. Sharma N, Howlett J. Current state of cardiac amyloidosis. Current opinion in cardiology. 2013;28:242-248

170. Falk RH, Dubrey SW. Amyloid heart disease. Progress in cardiovascular diseases. 2010;52:347-361 
171. Azimzadeh O, Sievert W, Sarioglu H, Yentrapalli R, Barjaktarovic Z, Sriharshan A, Ueffing M, Janik D, Aichler M, Atkinson MJ, Multhoff G, Tapio S. Ppar alpha: A novel radiation target in locally exposed mus musculus heart revealed by quantitative proteomics. Journal of proteome research. 2013

172. Azimzadeh $O$, Scherthan $H$, Yentrapalli $R$, Barjaktarovic $Z$, Ueffing $M$, Conrad $M$, Neff $F$, Calzada-Wack J, Aubele M, Buske C, Atkinson MJ, Hauck SM, Tapio S. Label-free protein profiling of formalin-fixed paraffin-embedded (ffpe) heart tissue reveals immediate mitochondrial impairment after ionising radiation. Journal of proteomics. 2012;75:2384-2395

173. Barjaktarovic Z, Schmaltz D, Shyla A, Azimzadeh O, Schulz S, Haagen J, Dorr W, Sarioglu $\mathrm{H}$, Schafer A, Atkinson MJ, Zischka H, Tapio S. Radiation-induced signaling results in mitochondrial impairment in mouse heart at 4 weeks after exposure to x-rays. PloS one. 2011;6:e27811

174. Falk RH. Diagnosis and management of the cardiac amyloidoses. Circulation. 2005;112:2047-2060

175. Banypersad SM, Moon JC, Whelan C, Hawkins PN, Wechalekar AD. Updates in cardiac amyloidosis: A review. Journal of the American Heart Association. 2012;1:e000364

176. Hoving S, Heeneman S, Gijbels MJ, te Poele JA, Bolla M, Pol JF, Simons MY, Russell NS, Daemen MJ, Stewart FA. No-donating aspirin and aspirin partially inhibit age-related atherosclerosis but not radiation-induced atherosclerosis in apoe null mice. PloS one. 2010;5:e12874

177. Wang C, Chen L, Hou X, Li Z, Kabra N, Ma Y, Nemoto S, Finkel T, Gu W, Cress WD, Chen J. Interactions between e2f1 and sirt1 regulate apoptotic response to DNA damage. Nature cell biology. 2006;8:1025-1031

178. Luo J, Nikolaev AY, Imai S, Chen D, Su F, Shiloh A, Guarente L, Gu W. Negative control of $\mathrm{p} 53$ by sir2alpha promotes cell survival under stress. Cell. 2001;107:137-148

179. Gorenne I, Kumar S, Gray K, Figg N, Yu H, Mercer J, Bennett M. Vascular smooth muscle cell sirtuin 1 protects against DNA damage and inhibits atherosclerosis. Circulation. 2013;127:386-396

180. Mercer J, Figg N, Stoneman V, Braganza D, Bennett MR. Endogenous p53 protects vascular smooth muscle cells from apoptosis and reduces atherosclerosis in apoe knockout mice. Circulation research. 2005;96:667-674

181. Boesten LS, Zadelaar AS, van Nieuwkoop A, Hu L, Teunisse AF, Jochemsen AG, Evers B, van de Water B, Gijbels MJ, van Vlijmen BJ, Havekes LM, de Winther MP. Macrophage p53 controls macrophage death in atherosclerotic lesions of apolipoprotein e deficient mice. Atherosclerosis. 2009;207:399-404

182. van Vlijmen BJ, Gerritsen G, Franken AL, Boesten LS, Kockx MM, Gijbels MJ, Vierboom $M P$, van Eck $M$, van De Water $B$, van Berkel TJ, Havekes LM. Macrophage p53 deficiency leads to enhanced atherosclerosis in apoe*3-leiden transgenic mice. Circulation research. 2001;88:780-786

183. von der Thusen JH, van Vlijmen BJ, Hoeben RC, Kockx MM, Havekes LM, van Berkel TJ, Biessen EA. Induction of atherosclerotic plaque rupture in apolipoprotein e-/- mice after adenovirus-mediated transfer of p53. Circulation. 2002;105:2064-2070

184. Moore KJ, Tabas I. Macrophages in the pathogenesis of atherosclerosis. Cell. 2011;145:341-355

185. Lee MO, Song SH, Jung S, Hur S, Asahara T, Kim H, Kwon SM, Cha HJ. Effect of ionizing radiation induced damage of endothelial progenitor cells in vascular regeneration. Arteriosclerosis, thrombosis, and vascular biology. 2012;32:343-352

186. Mitchel RE, Hasu M, Bugden M, Wyatt $H$, Hildebrandt G, Chen YX, Priest ND, Whitman SC. Low-dose radiation exposure and protection against atherosclerosis in apoe(-/-) mice: The influence of p53 heterozygosity. Radiation research. 2013;179:190-199 
187. Ohashi K, Parker JL, Ouchi N, Higuchi A, Vita JA, Gokce N, Pedersen AA, Kalthoff C, Tullin S, Sams A, Summer R, Walsh K. Adiponectin promotes macrophage polarization toward an anti-inflammatory phenotype. The Journal of biological chemistry. 2010;285:6153-6160

188. Lovren F, Pan Y, Quan A, Szmitko PE, Singh KK, Shukla PC, Gupta M, Chan L, Al-Omran $\mathrm{M}$, Teoh $\mathrm{H}$, Verma S. Adiponectin primes human monocytes into alternative antiinflammatory $\mathrm{m} 2$ macrophages. American journal of physiology. Heart and circulatory physiology. 2010;299:H656-663

189. Okamoto $Y$, Kihara S, Ouchi N, Nishida M, Arita Y, Kumada M, Ohashi K, Sakai N, Shimomura I, Kobayashi H, Terasaka N, Inaba T, Funahashi T, Matsuzawa Y. Adiponectin reduces atherosclerosis in apolipoprotein e-deficient mice. Circulation. 2002;106:2767-2770

190. Tsubakio-Yamamoto K, Matsuura F, Koseki M, Oku H, Sandoval JC, Inagaki M, Nakatani K, Nakaoka H, Kawase R, Yuasa-Kawase M, Masuda D, Ohama T, Maeda N, NakagawaToyama Y, Ishigami M, Nishida M, Kihara S, Shimomura I, Yamashita S. Adiponectin prevents atherosclerosis by increasing cholesterol efflux from macrophages. Biochemical and biophysical research communications. 2008;375:390-394

191. Stienstra R, Duval C, Keshtkar S, van der Laak J, Kersten S, Muller M. Peroxisome proliferator-activated receptor gamma activation promotes infiltration of alternatively activated macrophages into adipose tissue. The Journal of biological chemistry. 2008;283:22620-22627

192. Bouhlel MA, Staels B, Chinetti-Gbaguidi G. Peroxisome proliferator-activated receptors--from active regulators of macrophage biology to pharmacological targets in the treatment of cardiovascular disease. Journal of internal medicine. 2008;263:28-42

193. Charo IF. Macrophage polarization and insulin resistance: Ppargamma in control. Cell metabolism. 2007;6:96-98

194. Bouhlel MA, Derudas B, Rigamonti E, Dievart R, Brozek J, Haulon S, Zawadzki C, Jude B, Torpier G, Marx N, Staels B, Chinetti-Gbaguidi G. Ppargamma activation primes human monocytes into alternative $\mathrm{m} 2$ macrophages with anti-inflammatory properties. Cell metabolism. 2007;6:137-143

195. van der Hoorn JW, Jukema JW, Havekes LM, Lundholm E, Camejo G, Rensen PC, Princen HM. The dual pparalpha/gamma agonist tesaglitazar blocks progression of preexisting atherosclerosis in apoe*3leiden.Cetp transgenic mice. British journal of pharmacology. 2009;156:1067-1075

196. Pakala R, Dilcher $C$, Baffour R, Hellinga $D$, Seabron $R$, Joner $M$, Kolodgie $F$, Virmani $R$, Waksman R. Peroxisome proliferator-activated receptor gamma ligand pioglitazone alters neointimal composition in a balloon-denuded and radiated hypercholesterolemic rabbit. Journal of cardiovascular pharmacology. 2006;48:299305 


Cardiovascular disease (CVD) and cancer are two leading life-threatening diseases in developed countries. The main underlying pathological cause of most CVDs is atherosclerosis, characterized by a chronic inflammatory response in the arterial wall. In the first part of this thesis, we focused on two immunosuppressive strategies to protect against inflammation-driven atherosclerosis. In chapter 2, we explored the potential therapeutic use of immunosuppressive drug FK506 (tacrolimus), targeting the calcineurin-nuclear factor of activated T-cells (NFAT) signaling pathway, in atherosclerosis. Transcription factors of the NFAT family have crucial roles in the development and function of the immune system and are tightly regulated by calcineurin, a calmodulin-dependent calcium-activated phosphatase, and NFAT kinases. NFAT has been considered as a target for therapeutic approaches that are aimed at regulating T-cell-mediated immune responses, like in the treatment of graft transplant rejection and autoimmune diseases. Low-dose 0.05 $\mathrm{mg} / \mathrm{kg} /$ day) FK506 treatment markedly reduced atherosclerotic plaque initiation and progression in apolipoprotein E-knockout $\left(A p o E^{-}\right)$mice, most likely by favoring anti-inflammatory M2-macrophage polarization, whereas this protective effect was not observed after high-dose treatment $(1 \mathrm{mg} / \mathrm{kg} / \mathrm{day})$. Moreover, high-dose FK506 treatment was associated with hypercholesterolemia, an adverse side-effect that has also been reported after the long-term use of calcineurin inhibitors in transplant recipients. These data show that FK506 dosage is critical for its therapeutic application in atherosclerosis.

To circumvent the regulation of undesired targets when blocking calcineurin, we additionally investigated the role of a specific isoform of NFAT signaling in T-cells, NFATC2, in atherosclerosis (chapter $\mathbf{3}$ ). As NFAT activation is indispensable for regulatory T-cell function and NFATC2 selectively promotes T-helper (Th) ${ }_{1}$-cell differentiation, we hypothesized that NFATC2 would be an excellent target for anti-atherogenic therapy. Although we observed a pronounced compensatory shift towards a $\mathrm{Th}_{2}$-immune response, NFATC2 deficiency, either specific in whole-body or hematopoietic cell-lineage, aggravated rather than protected against atherosclerotic plaque formation. An augmented proliferative response and effector/memory phenotype of NFATC2-deficient T-cells, more prone to migrate to the atherosclerotic lesion, contributed to the aggravated atherogenic response. 
In the next chapters, we focused on a unique interface between CVD and radiotherapy. There is a strong correlation between radiotherapy treatment and an increased long-term risk for developing CVD in breast cancer, Hodgkin's lymphoma and head and neck cancer patients. In previous experimental studies, we have shown that local radiation exposure to the carotid arteries of young hypercholesterolemic $A p o E^{\prime-}$ mice accelerated the progression of atherosclerotic plaques and predisposed to an inflammatory, thrombotic plaque phenotype. In chapter $\mathbf{4}$, we demonstrate that irradiation of preexisting atherosclerotic lesions in the aortic arch of aged $A p o E^{\prime-}$ mice resulted in a macrophage-rich plaque phenotype, more specifically pro-inflammatory M1 macrophages, with increased presence of intraplaque hemorrhage and apoptotic cells. These highly-inflamed plaques can augment the risk for cardiovascular complications. As the majority of cancer patients involve the elderly suffering subclinical cardiovascular damage, stratification of patients with a higher risk for CVD to enable tailored therapeutic approaches and early preventive measures should be a major future concern in our progressively aging society.

Breast cancer is one of the most common cancers among women. Each month almost 1000 women are diagnosed in the Netherlands (Netherlands Cancer Registry). There is abundant epidemiological evidence that breast cancer patients treated with radiotherapy have an increased risk of cardiac mortality, which is higher for left-side-treated than right-side-treated patients. In chapters 5 and 6 we addressed radiation-induced cardiac damage in wildtype $\mathrm{C} 57 \mathrm{BL} / 6 \mathrm{~J}$ and hypercholesterolemic $\mathrm{ApoE}^{-1}$ mice. Whereas mice were able to maintain cardiac function to a certain extent, progressive cardiac microvascular damage with increasing radiation dose and follow-up time, indicated by a loss of microvessels and endothelial cell injury in remaining vessels, was found. Consequently, cardiac irradiation caused vascular leakage, which was extensively observed after radiotherapy with $16 \mathrm{~Gy}$ as evidenced by diffuse myocardial albumin and amyloid deposition, and lead to sudden death. Although $\mathrm{ApOE}^{-/}$mice were protected from developing radiation-induced cardiac amyloidosis, as ApoE itself is one of the components of amyloid, hypercholesterolemia in combination with $16 \mathrm{~Gy}$ irradiation enhanced microvascular damage and accelerated coronary atherosclerosis development. 
In chapter $\mathbf{7}$ the major findings of this thesis and future directions are given. Potential underlying mechanisms of radiation-induced cardiovascular damage and possible targets for intervention, as well as the therapeutic potential of inhibiting calcineurin-NFAT interactions in atherosclerosis, are discussed. In conclusion, future research characterizing the roles of individual NFAT proteins in regulating immune cells, and their extent of overlap in function, is necessary for selecting the optimal target for developing NFATmediated immunosuppressive anti-atherogenic approaches. Novel immunosuppressive agents selectively targeting calcineurin-docking sites on NFAT can prevent unwanted side effects, thereby enhancing their therapeutic potential in the treatment of atherosclerosis. Our data further provide new insights into the pathogenesis of radiation-induced CVD, emphasizing the need to assess individual cardiovascular risk profile and to develop clinical preventive measures. 




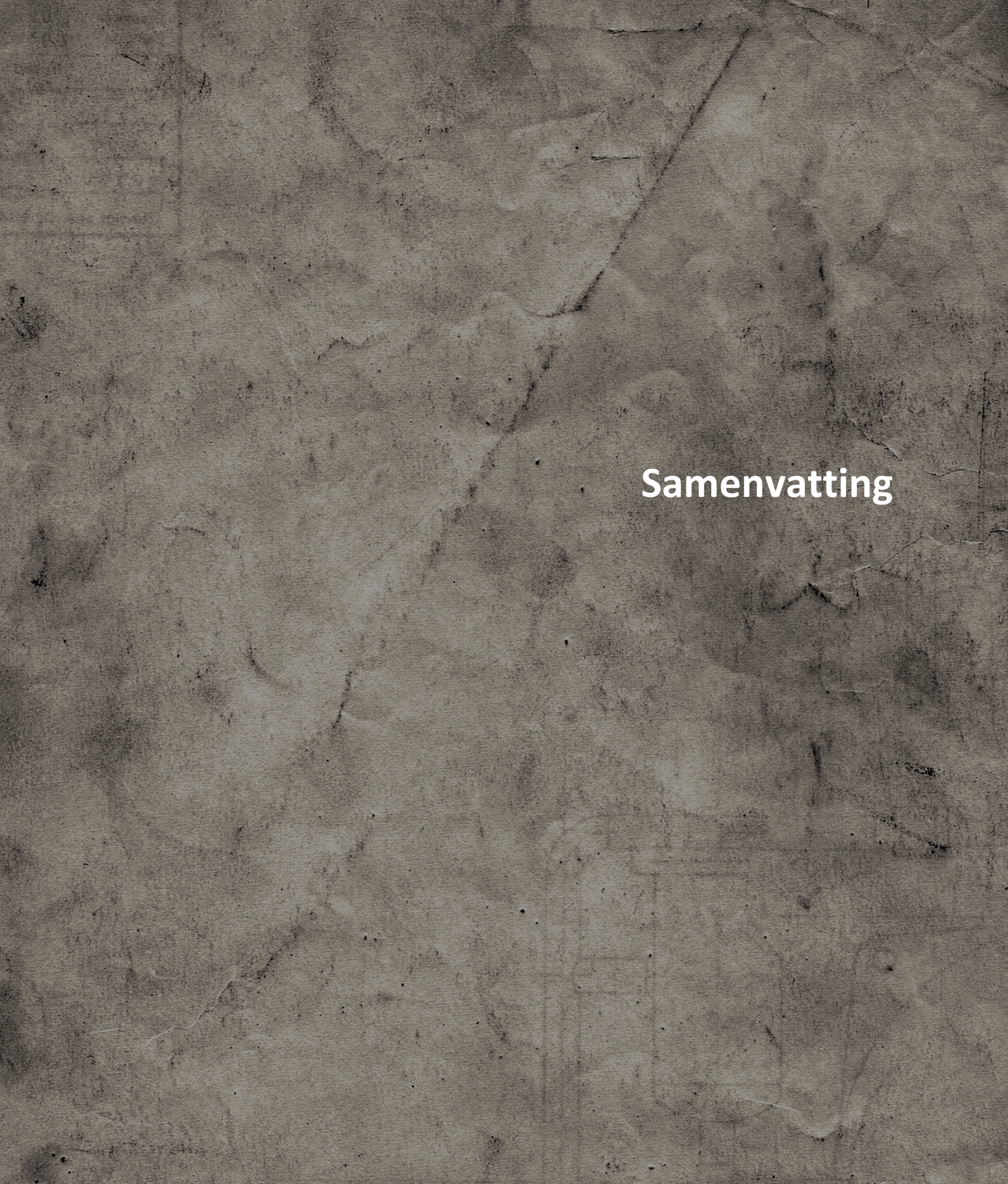


Hart- en vaatziekten en kanker zijn de twee meest voorkomende doodsoorzaken in de Westerse landen. Atherosclerose (of 'aderverkalking') is de voornaamste onderliggende oorzaak van hart- en vaatziekten en wordt gekenmerkt door een chronische ontstekingsreactie in de arteriële vaatwand. In het eerste deel van mijn proefschrift hebben we twee strategieën onderzocht die beschermen tegen de ontsteking in atherosclerose.

Als eerste hebben we in hoofdstuk 2 gekeken naar de behandeling met FK506 (tacrolimus), een medicijn dat het immuunsysteem onderdrukt door remming van calcineurine. Calcineurine controleert de werking van bepaalde transcriptiefactoren, genaamd NFAT's, die cruciaal zijn voor de activatie van een subset van belangrijke ontstekingscellen, de T-cellen. Medicijnen, zoals FK506, worden ook in andere ziekten waarbij het immuunsysteem geblokkeerd moet worden, zoals auto-immuun ziekten en bij orgaantransplantaties, gebruikt. Uit eerder onderzoek in ons laboratorium bleek dat behandeling met een lage dosis FK506 de start en verdere ontwikkeling van atherosclerose in een muismodel voor atherosclerose $\left(A p o E^{/-}\right.$muis) verminderde. In dit proefschrift is dit verder onderzocht. Daaruit bleek dat de lage dosis FK506 een effect had op de macrofagen en dat leidde tot een verhoogde aanwezigheid van anti-inflammatoire (M2) macrofagen. Dit beschermend effect werd niet geobserveerd na een hoge dosis FK506, sterker nog, de hoge dosis resulteerde in verhoogde cholesterol waarden in het bloed. Een hoge cholesterolconcentratie in het bloed is ook aangetoond na lang gebruik van calcineurine remmende medicatie door patiënten met een orgaantransplantatie. Deze resultaten geven aan dat de dosering een kritische factor is bij de effecten van FK506-behandeling van atherosclerose.

Om de neveneffecten van calcineurineremming te vermijden, hebben we vervolgens de rol van een specifiek subtype van de NFAT transcriptiefactoren, namelijk NFATC2, in atherosclerose onderzocht (hoofdstuk 3). Aangezien NFAT-activatie onmisbaar is voor het normaal functioneren van ontstekingsremmende T-helper $(\text { Th })_{2}$-cellen en NFATC2 selectief de werking van ontstekingsbevorderende $\mathrm{Th}_{1}$-cellen stimuleert, veronderstelden we dat blokkering van NFATC2 bescherming zou bieden tegen atherosclerose. Hoewel de afwezigheid van NFATC2 in atherosclerotische muizen wel de ontstekingsremmende $\mathrm{Th}_{2}$ immuun respons veroorzaakte, werd een verergering van de atherosclerose geobserveerd. Dit was te verklaren door een 
verhoogde aanwezigheid van een ander type T-cellen, de 'effector/memory' Tcellen, die een hogere reactiviteit vertoonden en meer geneigd waren zich naar de plek van atherosclerose te verplaatsen om daar de ontstekingsreactie te versterken.

In de volgende hoofdstukken van mijn proefschrift hebben we een unieke interactie tussen het ontstaan van hart- en vaatziekten en de behandeling van kanker bestudeerd. $\mathrm{Er}$ is een sterke correlatie tussen radiotherapiebehandeling en een verhoogd risico op hart- en vaatziekten op lange termijn bij borstkanker, Hodgkinlymfoom en hoofd/hals kankerpatiënten. Uit vorige experimentele studies van onze groep is gebleken dat lokale bestraling van de halsslagaders van jonge $A p o E^{-/}$muizen de ontwikkeling van atherosclerose versnelt en verergert. In hoofdstuk 4 tonen we aan dat bestraling van reeds bestaande atherosclerotische plaques in de aortaboog van oude $A p o E^{--}$muizen leidde tot macrofaag-rijke plaques, met name meer pro-inflammatoire (M1) macrofagen, met meer intraplaque bloedingen en meer dode cellen. Deze plaques zijn gevaarlijk, aangezien ze kunnen scheuren en er een bloedstolsel kan ontstaan. Sinds de meeste kankerpatiënten van oudere leeftijd zijn en daardoor al atherosclerose ontwikkeld hebben, ligt het risico op complicaties, namelijk een hart- of herseninfarct, bij oudere kankerpatiënten behandeld met radiotherapie mogelijk dan ook hoger. Het is daarom - in onze verouderende samenleving van groot belang patiënten met kanker en een hoger risico op hart- en vaatziekten te selecteren om zo de kankertherapie individueel aan te passen en preventieve maatregelen te treffen.

Borstkanker is één van de meest voorkomende kankers bij vrouwen. Elke maand krijgen bijna 1000 vrouwen in Nederland de diagnose (Netherlands Cancer Registry). Er is sterk epidemiologisch bewijs dat vrouwen met borstkanker, die behandeld zijn met radiotherapie, een verhoogd risico hebben op sterfte door een hartaandoening, waarbij het risico hoger ligt bij behandeling van de linkerborst dan bij behandeling van de rechterborst. In hoofdstukken 5 en 6 hebben we radiotherapie geïnduceerde hartschade onderzocht in normale en atherosclerotische $\mathrm{ApoE}^{-/}$muizen. Hoewel de hartfunctie van deze muizen redelijk goed behouden bleef, werd voortschrijdende schade aan de kleine weerstandsvaatjes in het hart gezien. Deze schade was erger na een hogere stralingsdosis en naarmate meer tijd 
verliep na de behandeling. De kleine vaatjes bleken ook niet meer goed te functioneren en lekten bloedbestanddelen (o.a. albumine) in het hart. Dit was waarschijnlijk de oorzaak van een verhoogde aanwezigheid van amyloid (abnormaal afgezette eiwitvezels) en de ontwikkeling van hartfalen. Hoewel we bij de $\mathrm{ApoE}^{\prime-}$ muizen geen amyloid zagen (omdat ApoE zelf een component is van amyloid), zorgden de hoge cholesterolconcentraties in het bloed van deze muizen in combinatie met $16 \mathrm{~Gy}$ bestraling voor meer schade aan de kleine vaatjes en een versnelde ontwikkeling van atherosclerose in de kransslagaders.

In hoofdstuk 7 worden de belangrijkste bevindingen uit dit proefschrift en verdere onderzoeksmogelijkheden aangegeven. Onderliggende mechanismen van straling geïnduceerde hart- en vaatschade en mogelijke opties voor interventie, alsook de remming van calcineurine-NFAT interacties als immuun onderdrukkende therapie voor atherosclerose worden bediscussieerd. Concluderend kan gesteld worden dat de rol van individuele NFAT-eiwitten in de ontstekingsreactie, en hun overlap in functie, verder onderzocht moet worden om het ideale eiwit te selecteren in de behandeling van atherosclerose. Nieuwe medicijnen, die selectief de binding plaatsen van calcineurine op NFAT blokkeren en als gevolg mogelijk neveneffecten kunnen voorkomen, moeten verder ontwikkeld en getest worden. Op deze manier kan hun klinisch gebruik in de behandeling van atherosclerose verbeterd worden. Ons onderzoek heeft ook nieuwe inzichten in de pathogenese van straling geïnduceerde hart- en vaatziekten opgeleverd, die de noodzaak voor het vaststellen van individuele risicoprofielen en de ontwikkeling van klinisch preventieve maatregelen bij patiënten behandeld met radiotherapie benadrukken. 




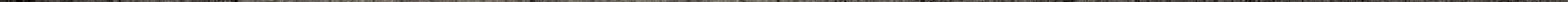


7KC

7-ketocholesterol

ALP alkaline phosphatase

ANGPT2 angiopoietin 2

AP1 activator protein 1

APC antigen-presenting cell

ApoE

apolipoprotein E

Arg1

arginase 1

BMDM bone marrow-derived macrophages

BMT bone-marrow transplanted

BSA bovine serum albumin

CAD coronary artery disease

$\mathrm{CCL} \quad$ chemokine ( $\mathrm{C}-\mathrm{C}$ motif) ligand

CCR CC-chemokine receptor

CDKN1A cyclin dependent kinase inhibitor $1 \mathrm{~A}$

$\mathrm{Cl} \quad$ confidence interval

CRP C-reactive protein

CsA cyclosporin A

CTGF connective tissue growth factor

CVD cardiovascular disease

$\mathrm{CXCL} \quad$ chemokine ( $\mathrm{C}-\mathrm{X}-\mathrm{C}$ motif) ligand

DAB diaminobenzidine

DCIR dendritic cell immuno receptor

DKO double knockout

EC endothelial cell

ECG electrocardiography

ECM extracellular matrix

EDN1 endothelin 1

EDV end diastolic volume

EF ejection fraction

Eff/Mem effector/memory 
EPC endothelial progenitor cell

ER endoplasmic reticulum

ESV end systolic volume

FACS fluorescence-activated cell sorting

FCS fetal calf serum

$\mathrm{Fe} \quad$ iron

FKBP FK506 binding protein

FN1 fibronectin 1

FOV field of view

Foxp3 forkhead box p3

FU follow-up

GATA3 GATA-binding protein 3

Gy Gray

GM-CSF granulocyte macrophage-colony stimulating factor

gSPECT gated single photon emission computed tomography

H\&E hematoxylin and eosin

HIF1 $\alpha$ hypoxia-inducible factor $1 \alpha$

HMOX1 heme oxygenase 1

HR heart rate

HRP horse radish peroxidase

HSA human serum albumin

Hsp heat shock protein

ICAM-1 intercellular adhesion molecule-1

IFN- $\gamma \quad$ interferon- $\gamma$

IGF1 insulin-like growth factor 1

IL interleukin

IMT intima-media thickening

iNOS inducible nitric oxide synthase

i.p. intraperitoneal

IPA ingenuity pathway analysis

i.v. intravenously 
LADCA left anterior descending coronary artery

LDLr low-density lipoprotein receptor

LN lymph nodes

LPS lipopolysaccharides

LRP-1 lipoprotein receptor-related protein 1

LV left ventricular

LXR liver $\mathrm{X}$ receptor

MCP-1 monocyte chemoattractant protein-1

M-CSF macrophage-colony stimulating factor

MDA malondialdehyde

MFI mean fluorescent intensity

MHC major histocompatibility complexes

MMF mycophenolate mofetil

MMP matrix metalloproteinase

$\mathrm{MR} / \mathrm{MaRc}$ mannose receptor

MVD microvascular density

NFAT nuclear factor of activated T-cells

NFKB nuclear factor $\mathrm{kB}$

NO nitric oxide

Nos2 nitric oxide synthase 2

oxLDL oxidized low-density lipoprotein

PAMP pathogen associated molecular pattern

PBS phosphate-buffered saline

PECAM-1 platelet endothelial cell adhesion molecule-1

PCR polymerase chain reaction

PDGF platelet-derived growth factor

PMA phorbol 12-myristate 13-acetate

PPAR peroxisome proliferator-activated receptor

qPCR quantitative polymerase chain reaction 
RIHD radiation-induced heart disease

RIN RNA integrity number

RorpT retinoid-related orphan receptor ${ }^{\top} T$

ROS reactive oxygen species

$\mathrm{RR} \quad$ relative risk

RT-PCR reverse transcriptase polymerase chain reaction

SD standard deviation

SEM standard error of the mean

SERCA sarcoplasmic reticulum $\mathrm{Ca}^{2+}$ ATPase

SMC smooth muscle cell

SPECT/CT single photon emission computed tomography

STAT signal transducer and activator of transcription

T-bet T-box transcription factor TBX21

TCR T-cell receptor

TGF $\beta \quad$ transforming growth factor $\beta$

Th T-helper cell

TIMP1 tissue inhibitor of metalloproteinase 1

TLR Toll-like receptor

TM thrombomodulin

TNF $\alpha$ tumor necrosis factor $\alpha$

Treg regulatory $\mathrm{T}$-cell

TXA2 thromboxane

VCAM-1 vascular cell adhesion molecule 1

VSMC vascular smooth muscle cell

vWF von Willebrand factor

WT wild-type

YM1 chitinase-like lectin 



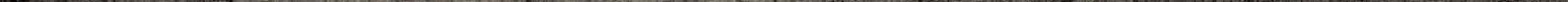




\section{Personal details:}

Name

Date of birth

Place of birth

Nationality

\section{Education:}

September 2009 - August 2013

January 2008 - August 2009

September 2004 - December 2007

September 1998 - June 2004
Karen Gabriels

February $18^{\text {th }}, 1986$

Genk, Belgium

Belgian
Department of Pathology, Maastricht University, the Netherlands

PhD student

transnational University Limburg (University of Hasselt/Maastricht)

Master Clinical Molecular Sciences

University of Hasselt, Belgium

Bachelor Biomedical Sciences

St-Augustinusinstitute, Bree, Belgium $\underline{\text { Latin-Mathematics }}$

Kootstra Talent Fellowship (Talented

Future Postdoc), Maastricht UMC

\section{Publications:}

Karen Gabriels, Lili Bai, Erwin Wijnands, Anette Christ, Haixiang Yu, Hafid AitOufella, Linda Beckers, Leon de Windt, Esther Lutgens, Mat J.A.P. Daemen, Ziad Mallat, Martin R. Bennett, Erik A.L. Biessen, Sylvia Heeneman. NFATC2 deficiency aggravates rather than protects against atherosclerosis by facilitating memory T-cell recruitment. Submitted

Karen Gabriels, Saske Hoving, Marion J. Gijbels, Jeffrey F. Pol, Johannes A. te Poele, Erik A.L. Biessen, Mat J.A.P. Daemen, Fiona A. Stewart, Sylvia Heeneman. Irradiation of existing atherosclerotic lesions increased inflammation by favoring pro-inflammatory macrophages. Submitted 
Karen Gabriels*, Saske Hoving*, Ingar Seemann, Nils L. Visser, Marion J. Gijbels, Jeffrey F. Pol, Mat J. Daemen, Fiona A. Stewart\#, Sylvia Heeneman\#. Local heart irradiation of $\mathrm{ApoE}^{-/-}$mice induces microvascular and endocardial damage and accelerates coronary atherosclerosis. Radiotherapy and Oncology 2012;105(3):358-64.

* Contributed equally (performing experiments and analyses)

\# Contributed equally (designing and supervision of the study)

Karen Gabriels*, Ingar Seemann*, Nils L. Visser, Saske Hoving, Johannes A. te Poele, Jeffrey F. Pol, Marion J. Gijbels, Ben J. Janssen, Fijs W. van Leeuwen, Mat J. Daemen, Sylvia Heeneman ${ }^{\#}$, Fiona A. Stewart*. Irradiation induced modest changes in murine cardiac function despite progressive structural damage to the myocardium and microvasculature. Radiotherapy and Oncology 2012;103(2):143-50.

* Contributed equally (performing experiments and analyses)

\# Contributed equally (designing and supervision of the study)

Hoving S, Heeneman S, Gijbels MJ, te Poele JA, Pol JF, Gabriels K, Russell NS, Daemen MJ, Stewart FA. Anti-inflammatory and anti-thrombotic intervention strategies using atorvastatin, clopidogrel and knock-down of CD40L do not modify radiation-induced atherosclerosis in ApoE null mice. Radiotherapy and Oncology 2011;101(1):100-8.

Karen Gabriels*, Lili Bai*, Erwin Wijnands, Mat Rousch, Mat J.A.P. Daemen, J.W. Cohen Tervaert, Erik A.L. Biessen, Sylvia Heeneman. Low- but not highdose FK506 treatment confers atheroprotection due to alternative macrophage activation and unaffected cholesterol levels. Thrombosis and Haemostasis 2010;104(1):143-50.

*Contributed equally 



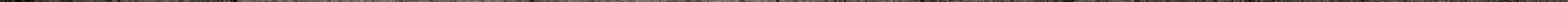


Tot slot nog een woordje van dank. Hoewel dit waarschijnlijk het makkelijkste en meest gelezen deel van mijn thesis is, vind ik het toch moeilijk om in enkele pagina's iedereen op gepaste wijze te bedanken. Alleen had ik dit namelijk nooit kunnen bereiken en daar ben ik iedereen oprecht héél erg dankbaar voor!

Allereerst wil ik graag mijn promotoren Prof. Dr. Daemen en Prof. Dr. Biessen bedanken. Beste Mat, ik ben je enorm dankbaar voor je vertrouwen en de tijd die je telkens weer vrij maakte voor onze meetings. Je kritische blik en capaciteit om discussies tot de kern terug te brengen hebben mij veel geleerd. Beste Erik, ik heb ontzettend veel bewondering voor je enorme wetenschappelijke kennis. Hoewel ik na onze meetings vaak even nodig had om al je creatieve ideeën op een rijtje te zetten, vergrootte dat vooral ook mijn motivatie en passie voor het onderzoek. Bedankt voor je steun alsook je interesse en input in onze (hopelijk ook toekomstige) stralingsstudies.

Prof. Dr. Heeneman, beste Sylvia, ik ben je ongelooflijk dankbaar dat je mij de kans gegeven hebt om dit onderzoek uit te voeren. Al tijdens mijn masterstage was ik enorm geboeid door stralingsschade en deze interesse is alleen maar groter geworden. Je hebt me steeds mijn eigen ding laten doen, maar mij toch ook gestuurd en bijgestaan als ik het nodig had. Dankzij jouw intensieve begeleiding en wetenschappelijke input heb ik mijn promotieonderzoek succesvol kunnen uitvoeren. Niet alleen op wetenschappelijk maar ook op persoonlijk vlak ben ik de afgelopen vier jaren enorm gegroeid. Jouw steun betekende daarbij enorm veel voor mij. Als directe begeleidster had ik het mij niet beter kunnen wensen! Dankjewel voor je vertrouwen in mij, dankjewel voor alles!

De resultaten in mijn proefschrift zijn de opbrengst van een vruchtbare, zeer prettige samenwerking met de mensen van het Nederlands Kanker Instituut. Dr. Stewart, beste Fiona, samen hebben we vele uren resultaten besproken en zijn we tot mooie conclusies gekomen. Jouw pensioen zal niet alleen gevoeld worden binnen het NKI, maar ook ver daarbuiten. Ik ben zeer vereerd dat jij mijn co-promotor bent! Ik kan je niet genoeg bedanken voor je hulp en input.

Ingar, Saske, Hans en Nils, ik voelde mij altijd erg welkom bij jullie in Amsterdam en ik ben enorm dankbaar voor jullie immense inzet voor onze 
stralingsstudies! Ik hoop dan ook dat jullie op 20 december dit mee kunnen vieren. Ik wens jullie het allerbeste toe, zowel privé als in jullie carrière!

Jeffrey, ondanks de eindeloos frustrerende uren achter de microtoom hoop ik dat dit boekje je een beetje voldoening kan geven, want dit is mede dankzij jou! Een hele dikke merci voor al je hulp! Ik ben blij dat je nu je hart volgt en ik wens je het allerbeste toe voor de toekomst!

Dear Lili, thank you so much for giving me the opportunity to work with you on the FK506 study and to continue the NFATC2 research. I always appreciated you a lot as a colleague and friend! Being your paranimf gave me a special feeling, especially with our beautiful Chinese dresses $(;)$ I really hope we stay in touch and one day we can meet again.

My dear Anette, how can I ever thank you enough... Your support, friendship and scientific help during these four years meant everything to me! We shared so much, we had nice, cozy, funny, intensive, crazy moments, and I know we will share many more of these moments in the future. I miss you so much and I wish you all the best in Worcester!

Lieve, een dikke merci voor al je steun! Onze babbels, zowel bij je thuis als op het werk, zijn altijd erg opbeurend en verhelderend voor mij. Ik ben dan ook heel erg blij dat je mij ook tijdens mijn promotie wil bijstaan als paranimf. Je wetenschappelijke kennis en optimisme zijn echt van onschatbare waarde voor de groep.

Marion, dankjewel dat ik bij jou niet alleen met mijn coupes terecht kon, maar ook voor een gezellige persoonlijke babbel! Jouw enthousiasme werkt steeds aanstekelijk en ik apprecieer enorm je eerlijkheid en steun.

Judith, ook jou wil ik heel erg bedanken dat ik altijd bij je terecht kon voor steun en raad. Ik heb altijd erg genoten van de gezellige avonden bij je thuis (hoewel onder bepaalde omstandigheden de weg er naar toe niet vanzelfsprekend was $(;)$ ). Ik heb heel veel respect en bewondering voor de manier waarop je je passie voor onderzoek combineert met je mooie gezin. Ik hoop dat ik dit ooit kan evenaren.

Erwin, dankzij onze NFAT-studie heb ik het geluk gehad je enorme FACSexpertise te mogen ervaren. Maar dat niet alleen; tijdens al die FACSexperimenten is er ook een vriendschappelijke band ontstaan. Voor een babbel kunnen we steeds bij elkaar terecht, hoewel de onderwerpen niet altijd even hoogstaand zijn $(;$. 
Timo, wat gaat het een grote aanpassing worden voor de groep als we binnenkort TimoPedia niet meer kunnen raadplegen. Dankjewel dat je altijd bereid was om mij te helpen, je bent er één uit de duizend! Ik wens je heel veel succes toe bij Sanquin en alle geluk in Amsterdam!

Jeroen, je was een zeer loyale collega en ik heb altijd erg graag met je samengewerkt. Doe het verder goed in je nieuwe baan en heel veel geluk samen met Stefanie en Finn!

Bart, ik vond het heel tof om kamergenootjes te zijn! Hoewel het niet altijd even gemakkelijk voor je is, blijf je toch steeds gemotiveerd en toon je een enorme inzet. Daar heb ik veel bewondering voor! lk wens je nog superveel succes en alle geluk toe voor de toekomst samen met Noor!

Ine, ik heb je leren kennen als een tof en behulpzaam iemand. Ik wens je veel moed met het afronden van je proefschrift, veel succes bij Janssen en een mooie toekomst voor je gezin! Je verdient het!

Thomas en Elke, voor jullie is geen enkele vraag te veel! Bedankt voor jullie vele hulp tijdens het werk, maar zeker ook voor de gezellige praatjes tijdens jullie dagelijkse nood aan cafeïne en voor het zorgen van de nodige sfeer en entertainment als het tijd was voor ontspanning. Veel succes verder met jullie onderzoek!

Anjana, I am happy that we not only share a room, but also our experiences, frustrations, personal stories... Thank you for being there for me! I admire you for knowing exactly what you want.

Uiteraard zijn er nog veel meer mensen die ik graag wil bedanken voor de afgelopen jaren. Allereerst de analisten: Anique, Clairy, Mat en Petra, van harte bedankt voor jullie ondersteuning! Ik waardeer het enorm dat ik altijd langs kon komen voor hulp of een babbel. Marjo, Emiel en Nadine van Molgen/Pathologie, super bedankt voor jullie input en steun! Jack, dankjewel voor je onmisbare quantimet programma's! Ook dankjewel aan mijn 'kleine demo' kamergenootjes Suzanne, Karin, Floor en Joep voor de leuke babbels en de fijne sfeer!

Vervolgens ook een niet-te-vergeten dankjewel aan alle andere (ex-) collega's voor jullie hulp en gezelligheid! Wouter, Dirk, Indira en Mathijs, toen ik begon waren jullie als oudere generatie een voorbeeld. Het was dan ook raar toen 
jullie er niet meer waren. Prof. Dr. Lutgens, beste Esther, bedankt dat ik ook bij jou terecht kon met vele vragen! Veronica, it always makes me smile when I think of you. Bea, our trip to Sevilla is unforgettable! I wish you all the best for the future and lots of happiness! Marjorie, thank you for the nice time we had! I hope I will get the opportunity to visit you once in Marseille. David, good luck with your new job! I hope we can toast together with (one!!) Jägermeister on December $20^{\text {th }}$. Linda en Tom, ik hoop dat ook jullie mijn promotiedag mee kunnen vieren! Het allerbeste nog in Amsterdam en Linda, als je weer in Dilsen bent, hoop ik echt dat je eens binnenspringt in de Kersenweg! Isabelle, Marco, Cora, Brenda, Sofia, thank you all very much! Jasper, Kosta, Chiara, Pawel en Sebastièn, good luck with all your projects!

De afdeling pathologie is groot en daarom wil ik iedereen, van welke kant dan ook, bedanken. Prof. Dr. Zur Hausen, beste Axel, hartelijk dank voor uw interesse! Eindelijk is mijn proefschrift klaar! Cor, Elly en alle dames van het secretariaat: dank voor alle hulp! In het bijzonder ook Danielle: bedankt voor je behulpzaamheid en bezorgdheid! Kathleen, dankjewel voor de leuke babbels op het lab! Benoit, bedankt voor alle moeite om snel voor de vele H\&Etjes te zorgen! Ook iedereen van de 'Epi's' wil ik bedanken voor de gezellige gesprekken. Veerle, het was altijd heel erg tof om een babbeltje te slaan op de gang en ik wil je enorm bedanken voor je KWF-ervaringen met mij te delen!

To all the co-authors of this thesis: Thank you for your excellent contributions!

Ook binnen MAASTRO wil ik Prof. Dr. Verhaegen, Dr. Ludwig Dubois, Patrick Granton en Natasja Lieuwes ontzettend bedanken voor alle tijd en hulp met de SSmART.

Prof. Dr. Lambin, ook u wil ik zeer hartelijk danken voor uw steun in mijn toekomstplannen en uw bereidwilligheid om voorzitter te zijn van de beoordelingscommissie van mijn proefschrift. Veel dank ook aan de andere leden, Prof. Dr. Crijns, Dr. van Eck, Dr. Germeraad en Prof. Dr. Tjan-Heijnen voor de tijd die jullie geïnvesteerd hebben in het beoordelen van mijn proefschrift. 
Ik wil ook graag alle medewerkers van het CPV bedanken voor hun hulp en ondersteuning bij onze muisstudies.

Tot slot wil ik nog een aantal bijzondere personen buiten het lab bedanken voor alle steun.

Willem, ik wil je graag bedanken voor alle tijd en moeite die je hebt gestoken in het maken van deze prachtige thesiscover!

Eline, Evi en Lize, de meiden in Maastricht/Londen, jullie weten als geen ander wat het is om te promoveren en zijn dan ook een enorm grote steun geweest! Merci dat jullie er altijd voor me zijn! Dit is wat ze noemen 'vriendinnen voor het leven'. Evi, ik heb enorm veel bewondering voor het avontuur dat je in Londen aangegaan bent. Ik ben superblij dat je nu de kansen krijgt die je verdient! Eline, ik ben enorm fier dat je mijn paranimf wil zijn! Lize, het is zo tof dat we niet alleen op het werk, maar ook thuis zo dicht bij elkaar zitten en altijd bij elkaar terecht kunnen.

De vriendinnen thuis, Julie en Anneleen, door alle drukte zien we elkaar heel wat minder dan we eigenlijk zouden willen. Nu kunnen jullie dan ook eindelijk eens zien waar ik zo veel tijd in gestoken heb $(-)$. We zijn al zo lang vriendinnen en dat zullen we zeker en vast voor altijd blijven.

Lieve Caroline, jouw zorgzaamheid en meeleven maken je een fantastische vriendin! Dankjewel dat ik bij jou met alles terecht kan! Als we weer even niet kunnen gaan zwemmen, mis ik onze babbels en gezelligheid (met chocomelk $:$ ) heel hard.

Niet alleen mijn familie, maar ook mijn schoonfamilie, wil ik heel erg bedanken voor alle steun, interesse en lekkere etentjes in de Hoogstraat!

Kim, we hebben elkaar nooit echt goed begrepen en we verschillen op zo veel vlakken, maar één ding hebben we zeker gemeen: de liefde voor Louize en Emma. Ik beloof dat ik hierna eindelijk wat meer tijd vrij zal maken voor Emma en dat ik er altijd voor haar zal zijn!

Mama en papa, ik kan met geen woorden beschrijven hoeveel jullie voor mij betekenen. De afgelopen jaren van mijn doctoraat hebben mij enorm veel geleerd en besef ik eens te meer hoe bijzonder het is dat jullie altijd klaar staan als ik iets nodig heb. Zelfs al werkten jullie dag en nacht! Jullie hebben mij altijd mijn eigen gang laten gaan en ik wil jullie bedanken voor het vertrouwen! Hopelijk hebben jullie met dit boekje en mijn verdediging op 20 december een 
beter beeld van waar ik het de afgelopen jaren zo druk mee heb gehad. Ik kan jullie niet genoeg bedanken voor de hulp en steun die jullie mij altijd gegeven hebben!

Wim, m'n alles, onvoorwaardelijk heb je mij gesteund in deze stressvolle jaren! Ik vind het geweldig hoe je kan uitleggen waar mijn onderzoek over gaat (;) en het is zalig hoe je samen met mij toeleeft naar 20 december. Dit wordt ONZE dag! Ik apprecieer enorm alles dat je voor mij doet! Elke dag geniet ik van het samenwonen en kijk ik er naar uit om na een lange dag werken thuis te komen in ons liefdevol nestje. Ik koester het geluk dat we samen hebben en kan niet wachten om te zien wat de toekomst voor ons in petto heeft! Zie je hemelsgraag! 
